\title{
"Leven zonder werk" : een sociaal-wetenschappelijk onderzoek naar arbeidsongeschiktheid
}

Citation for published version (APA):

Merens-Riedstra, H. S. (1981). "Leven zonder werk" : een sociaal-wetenschappelijk onderzoek naar arbeidsongeschiktheid. [Doctoral Thesis, Maastricht University]. Rijksuniversiteit Limburg. https://doi.org/10.26481/dis.19810101hm

Document status and date:

Published: 01/01/1981

DOI:

10.26481/dis.19810101hm

Document Version:

Publisher's PDF, also known as Version of record

\section{Please check the document version of this publication:}

- A submitted manuscript is the version of the article upon submission and before peer-review. There can be important differences between the submitted version and the official published version of record.

People interested in the research are advised to contact the author for the final version of the publication, or visit the DOI to the publisher's website.

- The final author version and the galley proof are versions of the publication after peer review.

- The final published version features the final layout of the paper including the volume, issue and page numbers.

Link to publication

\footnotetext{
General rights rights.

- You may freely distribute the URL identifying the publication in the public portal. please follow below link for the End User Agreement:

www.umlib.nl/taverne-license

Take down policy

If you believe that this document breaches copyright please contact us at:

repository@maastrichtuniversity.nl

providing details and we will investigate your claim.
}

Copyright and moral rights for the publications made accessible in the public portal are retained by the authors and/or other copyright owners and it is a condition of accessing publications that users recognise and abide by the legal requirements associated with these

- Users may download and print one copy of any publication from the public portal for the purpose of private study or research.

- You may not further distribute the material or use it for any profit-making activity or commercial gain

If the publication is distributed under the terms of Article $25 \mathrm{fa}$ of the Dutch Copyright Act, indicated by the "Taverne" license above, 
Promotor: Prof.dr. H. Phllipen

Feferenten: Prof.dr. J.B. Allegro

Frof.dr.J.J.C.B. Bremer

Het onderzokmaterlat werd verzameld op het Mederlands Institut voor Praeventieve Geneeskunde/TNo met een subsidie van het Arbeldsongeschiktheldsfonds 


\section{INHOUD}

HOOrdstuk 1 INLEIDING

1.1. Het leven zonder werk

1.2. Het aantal niet-werkenden

1.3. De betekents van arbela

1.4. Het arbe1dsongeschikt-zijn

Hoofdstuk 2 VRAAGSTELLING EN OPZET VAN HET ONDERZOEK 30

2.1 De vraagstelling van het basisonderzoek 30

2. 2. De vraagsteli1ng van het definitleve onderzoek 39

2.3. De materlaalverzameling

2.4. De samensteling van populaie en steekproef

Hoofdstuk 3 BASISGEGEVENS ROND STEEKPROEF EN WARIABELEN

3.1. De concretisering van de vraagstelling

3.2 . De subgroepen nar leeft1ja, beroep en aandoening

3.3. De steekproef geteld

3. 4. De herkomst van de steekproef

3.5. De steekproef en het universum van alle arbeidsongeschikten

3.6. De afhankelijke variabelen

3.7. De onafhankelijke variabelen

3.8. Gemldalden en sprelding der varlabelen per subgroep en duurgroep

Hoofdstuk 4 DE BELEVING VAN HET LEVEN ZONDER WERK NA 4, 10 EM 16 MAANDEN ARBEIDSONGESCHIKTZIJN

4.1. De beleving op de verschillende momenten

4.2. De achtergronden ven de satisfactle met het dage11 $\mathrm{ks}$ bestaan

4.3. De achtergronden wan de algemene levenshouding

4.4. Overeenkomsten en verschilien tussen de twe believingsdimensies

4.5. Overeenkomsten en verschilien tussen de subgroepen

4.6. Samenvat ting 
HOOPdOTUK 5 DE VERMPEATNGEN VAN 4 TOT 16 MAANDEN 106 ARDEIDSONGFSCHIKT-ZI 』N

5.1. De ronting der veranderingen 106

5.2. De achtergronden wan de verander 1 ngen in 110

de beleving van het arbeldsongeschikt-zijn

5.3. De invloed van de ervaringen na 4 mander

5. 4 samenvatering

HOOPQTUK 6 VERGCHILLEN TUSSEN DRIEMAH

6.1. Wergchilien in basiskenmerken 119

6.2. Werschilien in onderzokvariabelen 121

6.3. Samenvatting 129

HOOL"DSUK I SAMENVATMING EN BESPREKING VAN DE ONDERZOEKUITKONSTEN

7. ג. Samenvatting wan de ultkomsten

133

7.2. De beteken1s wan de verschillende facetten

140 wan het leven zonder werk

7.3. De relkw1jate van de onderzoekultkomsten

15,6

7. 4. Apbejasongeschlkten, werklozen en anderen

158

7.5. Enkele kr1t1sche kantteken1ngen

160

7.5.1. Niet onderzochte factoren

160

7.5.2. mheoretische perspectieven; ultgangspunten 168

7.6. Mabeschouwing

LITERATUUR

BIJ JAGEN 
VOORWOORD

Dit proefschrift is het resultast van een grondige herbewerking van materiaal dat in het kader van het basis-onderzoek "Leven zonder werk" werd verzameld. Van dat onderzoek werd versiag gedaan in een drietal publieatles, verschenen b1y het Nederlands Inst1tuut voor Praeventieve Geneeskunde (Gezondhe1dszorg), alwar $1 \mathrm{k}$ toen werkgam wa:

H. Merens-R1edstra, "Leven zonder werk", een onderzoek b1J arbeidsongeschikten.
* eerste deelversiag
Le1den, NIPG/TNO, november 1975
- tweede inter inverslag.
Lelden, NIPG/TNO, februar1 1977
- elmaversiag Le1den, NIPG/TNO, december 1978

D1t basis-cnderzoek werd geflnancierd door het N.I.P.G. afgezien van een subsidie op de lnterwlewkosten van het Arbelisongeschiktheldsfonds. De interviews werden ultgevoerd door de Nederlandse stichting voor statistiek.

het spreekt vanzelf dat bif deze instellingen verscheldene personen hebben bljgedragen tot het welslagen van het basisonderzoek.

Van hen w11 1 k graag noemen mevrouw J. de Lange (documenta11ste), I. Gerkema (programmeur) en J. Hendriks (mechanische databewerking), van wier deskundigheld ik gerulme tijd heb mogen profiteren.

Datzelfde geldt voor mevrouw A.M.H.L. Melchers, die als student-assistente een deel van het vele analysewerk voor har rekening heeft genomen, en voor de heren W.N. wan Nooten, $P$. van Leeuwen en M.M. van der Klaauw, die In de eerdere reapectlevelijk latere onderzoekfasen mijn tekort aan kennis en vaardigheld op statisch gebled aanwulden.

Zonder $P$. vam Leeuwen zou dit proefschrift zelfs noolt het licht hebben gezien. zijn nimmer aflatende belangsteli1ng vormde een onmisbare voedimgsbodem en klankbord voor mign activiteiten an de schrijftarel thuls. 
zonder M.M. van der Klaww zouden de vele statistache bewerkingen minder systematisch, minder efiectief en met veel meer moelte minerzida tot stand zin gekomen.

Een mintene even eerrolle vermelding werdlent mish promotor, prof.dr. H. PhLl1psen. Ms Jn belangstelling voor soclologisch onderzoek, met name op het terreln van de medische soclologle, heeft hij in de laatste jaren van mijn studie in goede banen gele1d. Een van de vruchter daarvan is dit proefschrift. 21jn bljdrage aan de opzet en de ultwerking van het defindtive onderzoek hebben de essentiele kenmerken van dit proefschrift bepald. Suggesties en commentaar aly altijd op zeer plezler ook mevroum prof.dr. M.J. Drop heeft miln soclologsiche loopbaan van het begin tot op heden gerlcht en gevolga. De eerste kneepjes van de soclologische onderzoekprakt1jk heb ik van haar geleerd; bij de opzet van het basisonderzoek z1jn haar op-en aanmerkingen mede rlchtinggevend geweest en ook in dit proefschrift zlin de gevolgen van haar kritisch oordeel aanwezl $\mathrm{B}$ *

De professoren dr. J.F. Allegro en dr. J.J.C.B. Bremer ben $1 \mathrm{k}$ erkentel1 $\mathrm{Jk}$ voor hun welwillende en grondlge aandacht voor het steeds weer "vrljwel laatste" concept van dit proefschrift. De Inhoudel1jke consistentie en overzlchtel1jkheld, respectievelijk de taglkundige duldelljkheld, van dit werkstuk hebben daar zeker baat b1j gevonden.

Het project Leven zonder werk had niet van de grond kunnen komen zonder de medewerking van vele verzekeringsgeneeskund1gen en adminlatratleve medewerkers van het $G A K$, het $S F B$ en de GMD die zorg hebben gedragen roor de selectle van respondenter voor het ondermok. Ik zal altija met wardering terugdenken an de tifd dat dit veelomvattende werk werd ultgevourid.

Het spreekt vanzelf dat de arbeldsongeschlkten, over wie het In dit proefsohrift 1 miners gat, door hun bereldheld om in lange, vermoelende interviews veel van zichzelf bloot te geven een wel zeer belangrijke bljdrage aan het welslagen van het onderzoek hebben geleverd. Ik hoop dat $z 1 \mathrm{~J}$ begrip kunnen 
opbrengen voor het felt dat hun individuele ervaringen nlet allemaal even duldel1jk in dit proefschrift terug te vinden zi.jn.

Verder gaat mijn dank uft nam degenen die de uiteindeI1 Jke vormgeving van dit manuscript bepaalden. Niets dan lof komt mevrouw A. Schmitt-Mu1t toe, die met onvermoelbear enthousiasme de verschiliende versies typte en adviseerde omtrent indelings, lay out en druk.

Aan mevrouw E.J. Deutekom hebben de tabellen en schema's hun fraale aanzien te danken.

Last but not least moeten mifn man en kinderen genoemd worden. De eerste $1 \mathrm{~s}$ de elgenl1jke anstlchter van deze arbeld geweest en zijn (on)geduld was, hoewel niet steeds in dank aanvaara, wél nuttig en noadrakell $1 \mathrm{jk}$ blj het voleindigen ervan. Mijn dochters hebben mij, met prijzenswardige vanzelfsprekendhela de nodige uren achter het bureau gegund. Hun "ben de nu nog niet klaar met werken" klonk niet te vaak mar wel vaak genoeg. 
HOOFDSFUK 1

INLE IDING

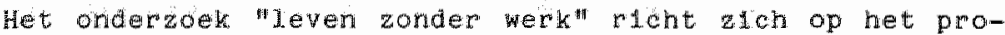
bleemgebled wan het arbeldsloos bestaan In het algemeen en het speclfleke karakter van het arbeidsongeschlkt-zign in het bijonder.

Het belang van exploratie van dit probleemgebied kan worden toegelloht met de volgende watremingen en overwegingen:

- Er zilin honderdalizenden onvrljw1111g niet-werkenden in Nederland en het zlet er niet naw ult dat het er spoedig veel minder zullen worden, integendeel.

- Desondanks gejdt grosso modo nog het calvinistische arbeldsethos: werken mot, althans wor de volwassen man; een plicht die resultaert in de praktijk dat lnderdaad de meeste mammen werken.

- Nibt-werkende ramen werkeren daardoor in een abnormale situatie; niet-werken 18 niet normal: niet gewoon en ook niet goed. Daar komt bij dat er bij het ophouden met werken ook een elmá komt an bljuorbeeld de soclale contacten, het prestatiegevoel, matschappelljke status en de normale dagelijkse regelmat.

- Werklozen en arbeldsongeschikten kan men beschouwen als (gedwongen) ploniers op een onontgonnen matschappelijk en persoonl1jk terpeln, warin werken geen feltelijke centrale ral speelt.

- Het leven zonder werk 1 s voor ambidsongeschikten over het algemen relat lef onontkoombar en langaur 1 *

- Arbeldsongegchikter verenigen twee "afwijkingen" in zich: eon zlekte of handlcap en het nlet-werken. De begeleiding In het kader vari de ziektewet en de Wet op de Arbeldsongesch1ktheldsverzekering richt de aandacht in zeer sterke mate op het eerste. Men kan zich afvragen of de aandoentng voor de betrokkene zélf ook zo'n overheersende rol speelt. 
Op grorid van dit alles leek onderzoek nas de lmhoud van het leven zonder werk wan arbeldsongeschlkten gewenst. Alworens daarop in de volgende hoofdstukken in te gan, zullen eerst de achtergronden var het onderzoek, zoals in het bovenstaande global aangedu1d, nader worden omschreven.

\subsection{Het leven zonder werk}

In dit anderzoek wordt met "leven zonder werk" of "arbeldsloos bestaan" de sltuatie aangeduid, warin degenen werkeren, die het verrichten van inkomen-vormende arbeid hebben moeten staken, doch qua leertija gerekend worden tot de potentiele beroepsbevolking (15-65 jarigeny.

Met andere worden: het leven zônder baan, na een leven mét baan, terw1jl men de pensloengerechtigde leeftijd nog niet heeft bereikt.

Het zo bedoelde leven zonder werk 1 s een 1ntrigerend verschljnsel, wanner men beseft dat het aantal mensen dat het leldt (of eraan $11 j \mathrm{dt}$ ) al jaren in honderdaulzendtalien wordt uitgedrukt, terwijl. werken, dat w11 zeggen het verrichten van geregelde inkomen-vormende arbeld, nog steeds van centraal belang wordt geacht in het individuele en matschappelijke leven.

Hoewel deze situatie al gerulme tija bestat, is er nog weindg gefundeerd inzlcht in de gevolgen ervan. Wat doet de Nederlandse samenleving met deze kloof tussen nom en werkelijkheid en wat moet degene, voor wie de werkejulkheld van het arbeldsloos bestaan onontkoombaar 1s, ermee aan?

Vooral het tweede deel van deze vragg, de individuele cevolgen van de botsing tussen norm (werken) en felte11 ke situatle (niet-werken), is een belangrijke anle1d1ng tot dit onderzoek geweest (Strolnk 1972, MerensRLedstra en Stro1nk 1972 ). 


\subsection{Het antal nuet-werkenden}

Op bas van verschlilende gegevens kan worden gesteld det het total antal deelnemers ar het arbeldsproces al jaren zowel un absolute antalien als ten opzlcht wan het aantal potentlele deelnemers da 15-65 Jarigen) dalende 13 .

In de eersue plata loopt de beroepsbevolking ${ }^{2}$ in verhouding tot de totale bevolking terug, dat wil zeggen dat het aantal. werkenden ên werkzoekenden tezanen relather kleiner word. In de tweede plaats neemt het aantal niet-werkenden 20 wel buten als binnen de beroepsbevolking toe.

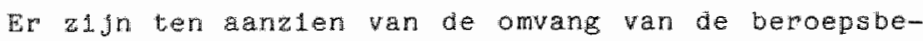
volking, of wel het arbeidsaanbod, verschlliende processen warneembar die de laatste twinta jaar de terugGang veroorzakt hebben. 2 )

- steeds meer jongeren treden later top tot de beroepsbevolking.

Verlenging van de leerplicht en langere vrijwillige deelname ar het onderwija doen, zowel bij jongens als bij melsjes, de leeftijd bij coetreding tot het anbeldsproces sijger.

- Eveneens voor belde sexen geldt dat velen korter tot de beroepsbevolking gaat behoren door ulttreding vór de pensloengerechtigde leeftija.

vervroegde pensionering, vrijwlilige ulttreding, ontslag $0 . q$. a f 10 eling en blivende arbeldsongeschikttheid aljn respectevelifk ultshutend en in sterke mate blj ouderen voorkomende oorzaken van het verlaten van de beroepsbewolking.

- Let hannel1Jk arbe1dsaanbod 1 in de leeft1jdscropen van global 25-60 jaar daat door het waker wookomen van blijvende arbeldsongeschiktheld. Dat hlerbij, evenals blj de vorige punten, zij het daar in minoere mate, de vrag nar arbeld een rol speelt, komt later nog an de of de. 
De enige tendens die tegen deze drie ontwikelingen ingaat is de toename van het arbeldsambod van vrouwer van slobaal 25-55 Jaar. De tot het arbeidsproces toetredende vrouken worden in aantaj echter voorbujgestreefd door de (nog) niet toetredende en eerder ulttredende mannen en vrouwen.

Al met al is de omvang van de beroepsbevolking, hoewel absoluut licht gestegen, ten opzichte van de totale bevolking (van 15 jaar en ouder) gedaald.

Tabel 1 geeft hiervan een beeld over de perlode 19711980 .

Tolbe 2 1. Beroegsberolking in procemten van de total

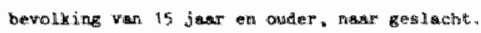

197 : 1 /

\begin{tabular}{|c|c|c|c|}
\hline jaer & mannen & HFoursem & Tokalal \\
\hline $\lg m$ & 76.0 & 25.8 & 50.15 \\
\hline 1972 & $75 . ?$ & eीt. & 50.6 \\
\hline 1973 & 74,9 & 26.9 & 49.9 \\
\hline 1974 & 73.7 & 26.6 & 40.15 \\
\hline 1.975 & 12.3 & 27.10 & 49.3 \\
\hline 1976 & 71.4 & $2 \% .8$ & 48.9 \\
\hline 197 & 10.7 & 27.5 & 4.8 .8 \\
\hline $1978^{*}$ & 70.0 & 27.9 & 48.6 \\
\hline $1079^{*}$ & 69.3 & 28.4 & 48.5 \\
\hline $1980^{\circ}$ & 68.9 & 29,2 & $48, \ldots 7$ \\
\hline
\end{tabular}

x selsatirater

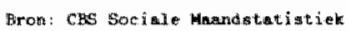

Nog meer den deze gestage afname van de beroepsbevolking ten opzlchte wan de totale bevolkyng 1s voor dit onderzoek van belang de absolute en relatieve toename van het aantal miet-werkenden binnen en buiten de beroepsbevolk1ng, met name van het aantal onvr1Jw11118 niet-werkenden.

Binnen de beroepsbewolking ziyn dat de tijdelljk arbeldsongeschikten en werklozen; daarbulten de langdurig 
arbelatorigschikten, dite geen werk (meer) zoeken. 3 )

In tabel 2 ajn ense elfers met betrekking tot deze categorien gerangshikt. Daran zijn de aantalien arbe1dsongeschikten aangeduld met de ziektewet- en whultker lngkgechtlgden, hetgen en conserwatieve schatting var het totaal aantal arbeldsongeschikter is.

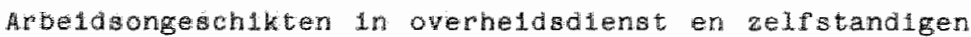

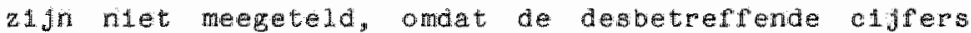
moellijk te achtexhalen zijn en niet te vergelljken met de ziektemet- en WA-c1jfers. Emaruel e.a. (1980) komen op grond wan het hun ter beschikking staande cljpermateriaal tot een schatting van het totaal aantal arbeidsongeschikten (dus inclusief ABP, WSW etc.) van 906.000 in 198.

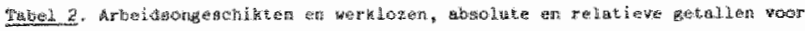
170 e $190 \%$

\begin{tabular}{|c|c|c|c|c|c|}
\hline \multirow[b]{2}{*}{ jä̀r } & \multirow{2}{*}{$\begin{array}{c}\text { WHo } \\
\{\times 1900\}\end{array}$} & \multirow{2}{*}{ 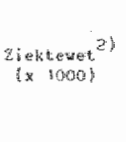 } & \multirow{2}{*}{ 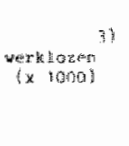 } & \multicolumn{2}{|c|}{ sotitald } \\
\hline & & & & 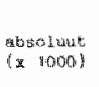 & 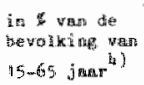 \\
\hline 1910 & 2115 & 205 & 45 & 1.65 & 6 \\
\hline 197 & 343 & $2: 40$ & 135 & $6 \mathrm{BA}$ & 8 \\
\hline $197 \%$ & 349 & 245 & 194 & $7 a$ & 9 \\
\hline 1076 & 37 it & 251 & 211 & Ey & 9 \\
\hline $197 \%$ & $\mathrm{HOH}_{4}$ & $25 \%$ & $20 \mathrm{~m}$ & क्षि? & 10 \\
\hline 1578 & 435 & 265 & 206 & $90 \%$ & 10 \\
\hline 1979 & 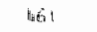 & 290 & $2 \div 0$ & $9 i_{i 1}$ & 10 \\
\hline $10(0)$ & $\operatorname{lag}_{a} x^{2}$ & $e^{2} e^{2 x}$ & 248 & nog6 & 11 \\
\hline
\end{tabular}

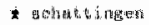

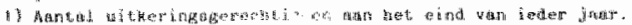

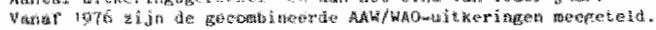

2) from ind

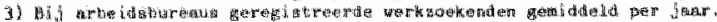

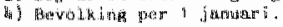

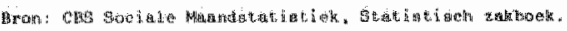

H1y de who-ers zijn degenen die nog wel enige arbeld vercichten megeteld. zdy vormen echter een kleine minderhedd, te sohatten op ongeveer $10 \%$. 4) 
Het aantal werkiazen is ultgedrukt in de blj de abbilisbureaus geregistreerde werkzokenden. Hiervan maken ndet alleen werklozen maar ook werkzokenden met een baan (de zogenaamde positleverbeteraars) deel uft. Sohatingen over hun aamoel in het totaal lopen nogal witeen, evenals over het aantal niet-gereglstreerde werklozen, watavan vooral werkzoekende vrowwen deel uitmaken. (WRR 1977. Droppert 1977, Kraayenstein en Verbaan 1978..) De werklooshelascijfers zijn derhalve minder betrouwbaar dan die betreffende de arbeidsongeschikten. Dit is echter geen bezwar wanneer, zoals hier, de clyters vooral vergelijkender igs gebrulkt women ter aandulding van een ontwikkeling gedurende enige Jaren.

B1 het waststelien van de zo duldelijke ontwikkilng In het laatste decennium van het a antal niet-meer-werkenden ligt het voor de hand te veronderstellen dat deze ontwikkeling zich in de toekoms wel zal voortzetten. Voorspellingen ontrent het aantal WAO-ers noemen aan ook het getal 800.000 voor 1990 en 1 miljoen voor 2000 (NRC/ Handelsblad 19.6 .80 en 14.8 .80 . Werkloosheldsprognoses komen niet meer onder de 400.000 .

ook ten aanzien van de andere niet-werkenden mag men aannemen dat eerder genoemde antwlkellngen (pag. 8) zich zulien voortzetten. Het is lmmers niet warschilnlijk dat jongeren minder lang onderwljs zulien gaan volgen.

Evenmin warschljnl1jk is het dat owderen langer in het arbeldsproces opgenomen zullen blijven: men denke slechts aan de problemen die het ouder worden met mee brengt in termen van de belasting door vele technologlsche en organisatie-ontwkkelingen. Hierblj moet tevens worden opgemerkt dat door de vergeyjuling wan de Wederlandse bevolking het aartal der niet-actiewen in de bevolkwng van 15-65 jaar nog extra toeneemt (via verm vroegd uitineden en dergelijke).

Hoewel de vastotelling dat er in Nederland 1 in de toe- 
komst zeer wele niet (meer) werkenden zullen blijven dierhalve gewettigd ifkt, ontoreekt nog een sluttende arguitentatie datrvoor. Deze dient op de dieperliggende oorzken van de masele arbeldsloosheld betrekking te hebben. Met name is de vraag van belang wardoor de masale afvloeling ult het arbeldsproces via VUT, vervroegde pensionering, werklooshe1d en arbeldsongeschlktheld tot stand komt.

Emanuel (1979) geeft een zeer helder overzlcht van de verichljuselen vooral op macro- en mesoniveau, die blj het antwoor op deze vraag betrokken zijn. Hij analyseert welswar de achtergronden van ameidsongeschiktbeid (1.c. het aantal. WAa-ultkeringen) maar zign betoog gat 1 in grote 11 Jnen even goed op voor andere categorieen nlet-meer-werkenden.

- In de eerste plates kan de gezondheld van de Nederlandse bevolking worden genoemd. Howel er geen aanlelding is om te veronderstelien dat de ulttreding ult het arbeidsproces verklard kan worden ult een voortbohrljdende verslechterding van de gezondheldstoestand van de Nederlandse bevolk1ng (H1lverink 1977), speelt de gezondheld in samenhang met de andere oorzaken wed degelljk een rol. Met name bij ouderen kan de gezondhela anlelding zijn tot al aan nlet vrijwillig vervroega ultitreden.

- Belangrijker zijn echter de soclaal-economische factoren op macro- en mesoniveau, die de vraagzijde van de arbeldsmarkt, zowel in kwentitetief als in kwalltatlef opracht, beinvioeden.

Emanuel (0.c. pag. 106-j22) w1jst hierbij op rendementsoverwegingen en autonome technlsche ontwikelingen die belde zowel het aantal arbeldsplation als de darvoor verestite kennls en vaardigheden beInvloeden. over de rendementsproblemen van de Mederlandse economie wordt reeds gerulme t1jd op verschlilende matschappeidye niveaus u1tgebreld gediscuseleerd5), watulf oonzak en vooral oplossingen tot grote 
meningsverschilien aanlelding geven. Ower het gevolg, de grote arntalien werklozen en arbelasongesahikten (waarmee men meestal alleen wao-eris bedoelt) heerst meer eenstemigheld, evenals aver de noodzaak (voomal op grond van de kosten der ultkeringen) ons streven op het verminderen darvan te riohten - hoe weinig succesvol dat ook moge lijken.

Immers: er is niet voldoende werk voor alien die willen en kunnen werken ${ }^{6}$ ) en het scheppen van nicuwe arbeidsplaatsen en/of oplelden van werknemers is niet makkelifk en kost $60 \mathrm{k}$ geld.

- Indien afstoting van arbeidsplatisen noodzakel1dk wordt geacht, zlin het sterk an het arbeldsaanbad gerelateerde factoren die bepalen wie er ontsiagen warden dan wel via vervroegd ulttreden, wervoegde pensionering of arbeldsongeschiktheld afvioeien. In alle gevallen hebben de kwetsbare groepen de neeste kans op afvloelirig: de "minder geschikten", die als zodantg gedefinleerd worden op grond van sexe, leertild, ervaring, ople1ding en eventueel handicap (van Zaal 1975, Van Zweeden 1976).

Dit laatste vergt enige toelichting.

Tot ziekmelding beslut over het algemeen de zleke cal heeft hij soms niet veel keus) en nlet zijn werkgever. Dat er echter werkomstandigheden $z 1$ in die mede aanleiding tot de zlekte of de zlekmelding kunnen vormen is inmidals wel bekend (rearganisaties, drelgend ontslag, tempo-elsen e.d.; zle het overzlcht ran studies naar zlektewerzulm van smulders, 1980 ).

Bovenalen speelt de werkgever een belangrijke rol bli het al dan niet bedindigen wan het langdurlo verzum e.q. het hervatten wan het werk. Ind1en de werknemer weer aan het werk kan en w1], blifkt de arbelamarkt net veel plaats voor hem te hebben: zljn oude, noch evertuele nleuwe, werkgever bllfken hem met open armen te ontvangen (IPM 1970). H1ermee 1 s het probleem van de in de wo verborgen werkloosheld geschapen. 
In atikel 21 sub $2 a$ van de WAO wordt mmers de moge11jkmeld geboden de werkloosheld te verdisconteren in de arbeldsongegchiktheld. Dat wil zeggen dat bly de vasutelikrg van de mate van arbeldsongesohiktheld de kansen op de arbetdsmark mogen worden meegerekerd. De shatingen omtrent het aratal elgenlijk werklozen onder de arbelisongeschikten Jopen udteen. Het hoogst genoemde aantal is \# 140.000 (V.d. Bosch en Petersen 1979; zle verder Becker 1979, W1ersma e.a. 1979, Van der Pa 1979, Zweeknorst 1961).

- Emanuel (o.c. pag. 98-105) noemt naast dit ho-artikel ook ancere aspecten var de who en haar uftwoering die hebben bijgedragen tot de toename van het arntal ultkeringsgerechtigden; met name de (rulmer geworden) criteria woor foekenning wan een ultkering en de hoogte var de uitkerlngen $z 1 j n$ daarbij van belang.

Het 1 s niet onwarschijlijk dat ditzelpde geldt voon de over lige loondervingswerzekeringen en uituredingsiegelingen.

- In dit verband moet dan gewezen worden op sooladcultureje ractoren, die de lndividuele wil en de matschappejijke dwang tot werken beinwloeden: het arbeldsethos (vooral de veronderstelde vermindering daawan), veranderingen in/verruiming van het ziektebegrip en gewijzigde opvattingen over de kwalleit wan het werk en de wakomstandigheden die anvaardbaar c.q. onaanvaandbaar zijn (Emanuel o.c. pag. 122-123). De invioed van deze factoren op het aantal niet-werkenden moet nog als veronderstelling Benoemd worden; voral, ten analen wan het arbeldsethos bestaan nog de nodige tudfels (zie par. 1.3 en 7.6)"

Dit ummer ultewerkte overztcht van de achtergronden van de masale arvloeling o.q. ultitreding ult het arbeldsproces had tot doel steun te bieden an de stelAng dat er in Neaerland ook in de toekomst veel nletwerkenden zullen zijn. De genoemde achtergronden zulien 
lmmers ook in de toekomst grotendeels amwezig blijven. Herblj dient echter nog éen kanttekening gemakt te worden.

Impliciet is bly bovenstaande beschouwlingen steeds het arbeldsbestel zoals dat nu 1 s ingericht wigngspunt Beweest. Dat w1 zeggen dat primalr gedacht werd aan werkgelegenheld in termen van volledige (40-urige werkweek) banen van de huldige kwalltedt.

In verschlliende publicaties wordt echter bearicumenteerd, dat door middel van herverdeling van arbeld (verm kort1ng van de arbeldsweek, 5-urlge werkdag, deeltudaarbe1d, educatlef verlor e.d.), en/of verbetering van de kwalleit van de arbeld (het aanpassen van het werk aan de wensen en capaciteiten van de werkers en niet andersom: humanisering van arbe1d) veel meer mensen in het atbeldsproces zowden kunnen worden opgenomen dan nu het geval is. Volledige werkgelegenheld "nieuwe stijl" zol met deze matregelen gerealiseerd kunnen worden VVan Zuthem 1972, WIR 1977, Soclal1sme en Democratie oktober 1978, Bron en Hamaker 1979, Allegro 1979, Emmerdj en Clobus 1979, NRC/Handelsblad 29.1.1980, Van Zweeden 1980).

Hoe noodzakel1jk en wenselijk deze zaken ook worden geacht, zij zijn nlet op grote schaal en op korte termijn te verwezenlijken, aangezlen z1j, nast nog moellijk te schatten financiele offers, nogal ingrijpende veranderingen in ons arbeldsbestel en $1 \mathrm{n}$ de samenleving a 1 s geheel impliceren. Bovendien doen $z 1 j$ nlets af aan het felt dat het niet-verrichten van inkomenvormende ambeld ook voor anderen dan de nu al darvan vrljgetelde kinderen, studenten, huisvrouwen en bejaarden een blijvend versohldnsel 1 s.

Zönder humanisering en herverdeling van arbela biljveth er enkele honderdalzenden die helemal niet (meer) werken, mét deze veranderingen blifft het nitu-werker bestaan, mar dan gespreid over meer mensen: woor ledereen zulien perioden van werken en niet-werker elkat 
artgewselen en al. "totale arbeldsloosheld minder voorkomen (Wahn en Wiener 1971).

Belde varianten hebben gemed dat de codxtontie van het net-werken met ret mog centrale belang van arbeld In het indulduele leven voorloplg weinig veedzam of teninding problematioch $1 \mathrm{~s}$.

\subsection{De betekends van arbeld}

De betekenls van arbeld voor de samenleving en die woor de Individuele mens zlyn in de loop der t1jd steeds meer met elkar gan samenhanger.

Beerling (1964, pag. 13) sohetst de volgende glabale ontwikkeling:

"1. Arbeld staat aanvankelljk aan de pand van het sociale bewatzijn, de zelfinterpretatie der samenleving gat eraan voorbij, omdat hij wordt wericht door groepen, die tot die samenleving niet of nawwelijks gerekend worden, terwijl het op pe1 houden erwar geen bijzondex probleem oplevert (het "onultput telijke slavenreservolr")."

Het verrichten van arbeld, en de betekemis die dat voom de arbelder: had, stomd geheel bulten het deelmemen aan en linrichten van de samenleving.

"2. Arbeid(en) en mens-zijn komen, in de christelijke opvatting, nader tot elkar te staan en de ontwikkellng van de techniek in het raam van de burger11 ik-kapltallstische economle makt de arbeld tenslotte tot het "soolale vraagstuk" bij ultnemendheld en dammee tot een hoofdcategorle van de menselidke zelfinterpretatie en zelfwardering." (Beerling 0.c. pag. 14)

Zeer terecht merken wan Wezel en de z1 Jnen 11976 , pag. 4) daarbid op dat

"de centralle plats van de arbeld als belevingscategore en de materle voorultgang de door industriele 
productie mogel1yk gemakt werd, anlelding ziJn geweest an de samenleving steeds meer als een arbeldsbestel in te richten. Dit kont order andere tot uiting in het gegeven dat het beroep at lemand ultoefent de basis vormt van gijn lnkomen en soclde Biatus. 7)

Onder arbeldsbestel verstaan wij met Van Doorm: het total van soclale posities en rollen, opgebouwd rond arbeldsprestaties van elke aard, en werenigd tot $\mathbf{l l}^{n-}$ beidsgroeperingen. 8 )

Hermee is onder meer gezegd dat de centrale platis die arbeld in de matschapplj heeft, gekoppeld $1 \mathrm{~s}$ a an de centrale plaats die arbeld in het leven van alle werkers, die nu wêl deel ultmaken wan de matschapplj, inneemt. 9 )

Als achtergrond voor dit onderzoek nat niet-arbeld is het noodzakel1jk de centrale plats van arbeld in het leven van het indlvidu wat concreter inhoud te gever. Howel in dit kader een historisch overzicht van de ontwikelingen 1 het denken over arbeid zeer Instructief zou zijn, zou in het korte bestek dat hier ter beschikklng staat aan de desbetreffende geschrlften geen reoht worden gedaran. 10)

Voor het inzicht in de huldige betekenissen van arbeld is enige aandacht voor het protestantisme en het marxisme echter geboden; in belide stromingen neemt arbeld een belangriljke plaats in.

Marx vat de mens, in navolging van Hegel, op als producent èn produkt wan zijn arbeid.

Hij produceert arbeld als midel tot de bevrediging van behoeften, In het bljzonder van de behoefte tot zelfrea 11 atie als zelfbewustzijnswezen. Daarmee $1 \mathrm{~s}$ hij tege11kkertijd produkt van $z i j n$ arbeld: door arbeld wordt de mens tot mat hif is. Marx acht dit geen reden tot wreugde. In de kapltalistische samenleving bejemmeren de arbeid en het arbeldsbestel lmmers de groel van het indlwidu tot wat hid zou kumen $z \mathbb{I n}$ : door arbeld wer- 
wreemdt de meng van zlohzelfin.

Deze isle op arbeld en de mens stoelt voornamellidh op watrumb en interpretatie van de in het kapitalisme orderaruke klagse, de arbelders. Via de groel van ween "Klasse an sich" nat een "Klasse fur sich" zouden de onderdruken in stat $21 J n$ het kapltalistisch systeem omver te werpen en een matschapplj te stlchten waarin de mens en geheel andere verhouding tot arbeld zou hebben. Werken zou weifswat moodzakellyk blijven, doch in grotere vritheld verricht worden en veel minder bepalend zidn voor het leven van de mens dan in Marx' tijd het geval. was. Mer zou een groot deel wan de dag kumen doen war men zin in had en de zelfrealsatie zou growendeels bulten de eigen arbeld tot stand komer.

De geschiedenis heeft ons inalddels geleerd dat Marx" utople gen werkelifkheld ls geworden: arbeid bepalt nog steeds in grote mate ons leven. Nlet alleen verknjot men door de elgen arbela een materieel inkomen om In de primalre levensbehoeften te voorzien cvoedsel, wleding, behulzLig), maar ook een psychisch inkomen: bevreding van de behoeften aan saclas contact, prest1ge, zelfwaraering en zelfrealisatie (Maslow 1954 , Emmerij 1980). Bovendien neemt arbeld nog betrekkelijk veed. tlja in beslag, zowel per dag als in jaren, waardoor het In grote mate de structuur van het leven bepaalt (Henry 1971). Bulten arbeld zijn er geen menselijke activiteiten ale deze cuncties op zo grote schaal blijken te kunnen vervulien. Dat dit niet altijd zo geweest is, blifkt onder andere ult de reeds angehaalde tekst van Berling. De vragh hoe arbeld dan wlin vele runcties heft gekpegen voert nat de protestantse, met name de calvinistische arbejdsethiek.

Max Weber heeft in "die protestantische Ethik und der Geist des kapitalismus" (1920) duldelijk semakt dat de calvinistische hoop op zaligheld, op ultverklezing door God, een ascetlsch leven gerlot op het leven van alledus en dus op hard werken noodzakelifk makte. Voor de 
calvinisten is de ultverkiezing tot behow door bod door predestinatie gegeven; mer kan er zelf niets toe bijdrageri.

Succes in de wereldiljke beroepsultoefening werd geloofd een vrifwel zekere aanwijzing te zijn dat men was ultverkoren.

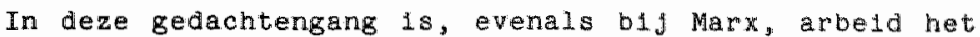
middel tot zelfrealisatie, echter nu als het alchtbaar maken van de altverklezing.

Weber betoogde dat de calvinistische arbeldsethiek, in combinatie met het religleuze voorschrift tot gedisciplineerd, ordelijk en sober gedrag, een grote blydrage leverde tot de ontwikkeling wan het moderne kap1ta11sme.

De Ideeén van Marx en Weber wijn geenszlns achterhaald; zlj geven aan welke betekenissen arbeld ook voor de 20 e-euwse mens kan hebben. In het kader van het onderzoek naar het leven zonder werk kumen deze betekenissen het best onderschelden worden in praktische en normat 1 eve.

De praktische functies van arbeid zijn gedeeltelijk reeds an de orde gekomen: arbeld verschaft een inkomen, soclale contacten, status, structur en regelmat.

Bowendien bepaalt de Inhoud van de arbeld in sterke mate wat men in de vrije t1jd doet en wat men denkt, voelt en wenst (Marx" "bovenbouw", zle ook Shostak en Gomberg 1965, Wippler 1968, Philipsen 1974).

De normatieve betekenis van arbeld is geworteld in de calvinistische arbeldsethiek. De religleuze achtergrond van de plicht tot werken is wellswar nlet voor ledereen even actueel meer, de plicht welf echter, geseculd seerd tot de plicht een nuttige bijdrage aan de matschapplj te leveren voor de meesten nog wel. 11)

D1t plichtsgevoed zou men kunien opvatten als de kern van de heersende arbeldsmoraal.

Deze werschillende betekenissen van arbeld letiden tot de veronderstelling dat het nletwerken om meer dan én reden over het algemeen als onplezierlg wordt ervaren. 
De nift-yerkende voldoet niet mer an de nork, noch in moreel noch in statistisch opzich (werken 1 s regel, niet-werken witzondering); wen verllest een belargrijk doel wan de soclale contacten, het matschappelijk aanzien daat en men heert een zee van ("vrije") tijd aje men ndet geleerd heeft op ardere whe dan met werkente whila en te structureren e.d.

Dat dit alemene beeld niet voor alle volwasen Nederanders opgat ligh voor de hand. Het is bekend dat vooral. jongewer soms niet zo order de lndruk zijn vam het eventhele primat van arbeld. Bij hen kan de mening worden bejulsterd dat werken in een baan éen van de vele mogej1jkheden is om je tijo te besteden. In abstractere termen: de werkofentatie ruimt plats in woor een grolore ortentatie op de vrlje tijd (Van Delden 1971, puldpgen 1974). De Grote toeloop nat de uitzendbureaus en de opkonst van de Experimentele Werk Bemlddeling (Strounk en Van Wijck 1973) zijn als symptomen van deze mentaldteltaverandering te zien. ook de wens tot deelt1ja-arbeld kan hierbij a ansluiter.

ofschoon een dergelijke minder nomatieve opvatting var werken warschijnljk vede aanhangers teit, $11 j k t$ van een: algemene aantasting van het tradictonele arbeldsethos nog geen sprake (Var wezel e.a. 1976). Veel mensen blijven inmers wan een plicht tot arbeid spreken (Smit 1978, noot di).

We1 zou men degenen met en meer alternatieve arbeidsorientatie kunner beschouwen als ploniers op hat terrein var het niet of niet "volledug" werken pioniers uit vrije wis, die run nom en werkejljkheld min of meer bij elikar doen aanslutten en zich daar redelijk in kunnen winden.

In dezelfde bealdaprak kunnen de onvrljwlilig niet-werknaen (anbeidsongeschikten en weklozen) beschouw worden als plonters tegen wil en dank. $21 \mathrm{j}$ women met

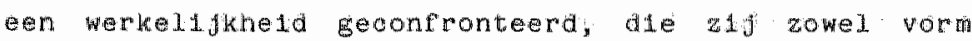
thoeter geven als van een "passende"l moral moeter voop- 
zlen om zich erin te kunnen welbevinden. Deze omstandigbeld is een goede reden om hun arbeidsloos bestaan an nader ondermek te onderwerpen.

\subsection{Het arbeldsongesenikt-21 in}

"Arbeldsongesch1kt, geheel of gedeeltellik $1 \mathrm{~s} h 1 \mathrm{j}$, die ten gevolge van zlekte of gebrek geheel of gedeelteI1jk buiten staat is on met arbeld de voor zijn kraohten en bekwamheld is berekend en ale met het oog op zijn oplelding en vroeger beroep hem in billijkheld kan worden opgedragen, ter plaatse waar hij arbeld verricht of het laatst heeft verricht of op een naburlge soortgelijke plaats, te verdienen hetgeen lichamel1yk en geestelljk gezonde personen, van dezelfde soort er soortbelijke opleiding, op zodanige plaats met arbeld gewoon1.jk veroienen."

Dit is de omschrijwing van arbeldsongesonlktheld, zoals die in de wet op de Arbeldsongeschiktheldsverzekering (WAO, art1kel 18) en de Algemene Arbe1dsongeschiktheldswet (AAW, artikel 5) staat vermeld. Ze houdt ongeschiktheld In voor alle, dus niet alleen het elgen, werk (mits passend) en ls als zodanlg van toepassing op mensen die langer dan een jaar (52 meken) geheel of gedeeltelifk geen arbeld hebben kunnen verrichten. Herop $1 \mathrm{~s}$ ook de betekenis van de term ambeldsongschikt in bet gewone taalgebrulk gebaseerd: langdurlg niet meer en warschijnligk noolt meer in staat tot (fullitime) werken. De term arbelasongeschiktheld kont echter ook in de zlektewet voor; het gaat dan alleen om de ongescrlktheld voor het elgen werk van mensen die gedurende maximat 52 weken hun (vroegere) beroep niet meer (volledig) udtoeienen.

In dit onderzoek zal met de term "arbeldsongeschiktzijn" het nlet meer werken ten gevolge van ziekte of 
gebrek worden bedoeld, ongeacht de tifdadur daarvan (minder of mer dan 52 weken). De volgende speciflcatie 15 hierbid echter wel van belang. De eerder genomde achtergrondzuage wan dit onderzok - wat moet men met een leven zonder werk als een lever mèt werk normal $1 s^{m}$ - lmplicert dat het arbeldsongeschict-z1jn hier allén aan de orde lo voor zover het tot het wolledig neerleggen van alle beroepsarbeld heeft geleld en voor zover het duldeligk fs dat dit nlet een zeer t1jdel1jke situathe 1. die spoedlg door werkhervatting weer wordt beetidiga.

Met deze begripsomschrifving, warvan specificatie volgt in de beschrljving van de onderzoekpopulatie (hoofdstuk 2), b11fft de vraag warrom ter bestuder1ng van bet leven zonder werk juist het arbeldsongesch1ktziln als bifzondere vorm daarwan gekozen is, en niet het werkloos- of (vervtoegd) gepensioneerd-zijn.

Het niet meer werken van gepensioneerden 1 al sinds Jaar en dag eer normale zak. Dat men met pensioen zal gaan is immers, afgerien an de exacte datum, een over het algemeen vaststaand en geaccepteerd gegeven.

Het niet meer werken behoort voor de pensioengerechtigden tot hun laatste levensfase. Dut hoeft niet te betekeren dat men er vol biljo verwachting naar uitkijkt, mear het overkomt ons allemal, en het staat, afgezien var de eventuele praktische problemen, niet onder de normatleve druk van nlet-werken terw $1 \mathrm{l}$ werken elgenlijk wordt verwacht.

Aldus spltst de vrag zlch toe op de keuze tussen drbeldongschlkten en werklozen als "slachtorters" van het arteldsloos bestarn. Voor belde categorlecn, veel meer dan voor geperisioneerden, is het niet-werken een min of meer plotselinge, niet zelf gekozen en abrormale situatie.

De woorden arbelisongeschlkt an werkloos geven overduldel1Jk de ontkenming weer van lets anders: arbeld/werk. De titel van dit onderzoek, "leven zonder werk", is dan 
ook met opzet gekozen: dit leven 11jkt geen elgen Imhoud te hebben, doch slechts niet het leven-mèt-werk te zijn. Het werschli tussen werkloosheld en arbelasongeschlktheld is allereerst gelegen in de anlelding tot het niet meer werken (dat de oorzaak van het onvr1jw1111g njet. meer werken vooral van (bedriJfs)economische aard 1 s, werd reeds betoogd; dat de aanleldyng tot ontsiag of afvloeling; vooral via de zlektewet en de WAO, van ind1viduele personen in individuele kenmerken moet worder gezocht eveneens). In tegensteling tot arbeidsongeschikten hebben werklozen geen zlekte, gebrek of handcap die hun toestand kan verklaren.

Dit 1mpllceert een tweede verschil: werklozen kunnen in princlpe meteen weer aan het werk, of althans pogingen daartoe ondernemen; arbeldsongeschikten moeten wachten tot hun wallaitelt verbeterd 1s. Werklazen kumen aus het ontslag èn het voortduren van hur werkloosheld over het algemeen wijten aan baas, bedrijf, economie of matschapp1j. Arbeldsongeschikten 11 jken echter tegen wil en dank doo" middel wan hur handlcap/ziekte zelf minstens mede aanlelding tot het ontstaan van hum elgen situatie te geven.

Hlermee is een derde verschil tussen arbeldsongeschikten en werklozen gegeven, dat hen ook, of waoral, 1 in de ogen van derden onderscheldt: arbeldsongeschikten hebben géen, of In leder geval minder, verwijtbare schuld aan hun arbeldsverzulm. Ziekte is immers nog de enige legitimering wan langdurig arbeldsverzuim. Economische factoren legitimeren Individuele werkloosheld niet, of niet ten volle, wo zlj al als oorzaken van werklooshedd worden (h)erkend; de werkloze acht men nlet altijd geheel. vrlj te plieiten van elgen "schuld".

Deze beoordeling van arbeldsongeschikten en werklozen wordt weersplegeld in de menlingen over misbrulk wan de soclale voorzleningen: men blljkt werklozen vaker te verdenken van werkonw1llgheld dan arbeldsongeschikten (WRR 1977). 
We redenen on ambeldsongeschlktem tot hoofdpersonen in tet onaerzoek naar het leven zonder werk te klezen, 11 gen $1 \mathrm{n}$ een comblnat van met name de erste twe verichliler met werlomer.

- Het gat $1 n$ dit onderzoek om langdurde, zo niet blijverd, niev meer werken (in sociale verzekerlngsterminologle: elnde arbeldsieven).

B1J arbeldsongeschikten, als totale categorle, is de kane darop groter dan blj werklozen. Immers: de aandoenling kan lreverglbel zifn. Bovendien blijkt, als de andoening toch verbetert of geheel herstelt, de arbeldsmarkt weinif rulmte te laten voor mensen met een ex-handzop. Af 1.1ngs - en ervardugsproblemen worden mensen die ziek zIn geweest vaak minder arbedasgeschikt geacht dan werkiozen.

Arbeidsongeschikten zullen dus vaker en eerder moeten beserfen dat hun arbeldsloos bestaan geen t1jdelljke onderbrektng van hun arbelidzarm leven 1 , mar een nieuwe blijvende levensfase.

- Min ar meer grondige herbezinning op het leven is voor arbeldsongeschikcen demalve in het algemeen onvermildedlfker dan voor werklozen, ook wat betreft de praktische zaker van alledag.

- Anders dan werklozen hebben arbeldsongeschikten behalve met het nlet-werken ook met een aandoenlng te maken. Ove het algemeen ligt voor butenstanders de nadruk op de ziekte of handicap: de ultwoerders wan de Zliktewet en de WAO concentreren hun aradacht vrywel ultwditend op de medsche kant van de arbeldsongesohlkheld, mar ook de leek assocleert arbeldsongesohlktheid in de eerste plats met ziek of gehandicapt zid.jn.

Onbekend $1 \mathrm{~s}$ echter of voom de arbeldsongeschikte zelf wijn leven eveneens primalr door de aandoening gekennierkt wordt en hoe naar aljn ervarlng de problematiek van de aandoenlng en die van het niet-werken zich tot 
elkaar verhowden.

Inzicht hlerin kan nuttig aljn bij al aan niet professionele contacten met arbeldsongeschikten en bly blyvoorbeeld de discussies rond de integratle van alle loondervingswetten.

De beteken1s wan het arbeldsongeschikt-zijn woor die arbeldsongeschikte is echter ook in andere opzichten nog $\mathrm{wr}_{1} \mathrm{Jwel}$ onbekend.

onderzoek en beleld betreffende arbeldsongeschikten concentreerde zich tot dusverre vrlywel ultsiultend op arbeldsongeschiktheld op macro- en meson1veau, op het arbeldsongeschikt-worden als medisch, Jurldisch, economisch en organisatorisch probleem voor werkgevers, het beariffsleven, de uitvoeringsorganen van de sociale verzekeringswetten. Men bestudeerde de oorzaken en aanleldingen tot (langdurig) verzulm, de procedures ter vaststelling van de (mate van) arbeldsongeschiktheld, de taak en rol van (verzekerings)geneeskundigen daarb1j en eventuele mogelijkheden ter reductie van frequentie en duur van verzutm en arbeldsongeschikthe1d.12)

Arbeldsongeschiktheid op microniveau, dat wil zegen als probleem voor de arbeldsongeschikte met de nadruk op het arbeldsongesch1kt-zijn als levensfiase, is nog grotendeels onbeschreven (en was dat zeker b1j het begin van dit onderzoek).

Incldenteel verschlynen, voorad via krante- en tijdschrletartikelen wel berlchten over de persoonl1jke ellende van enkele geinterviewde wA-ers, maar enloszins systematuche, objectiverende en kwantificerenda informatie omtrent het arbeidsongeschikt-zidn ontbreekt nog.

ook het recente boekje "wAO-ers, verhalen om te onthouden" (Bours 1980) voorzlet daar niet in, hoe helder en schrijnend het ook verschiliende facetten van bet arbeldsongeschikt-z1jn in beeld brengt. 13)

overigens betekent alt aldeg niet, dat er over de 
beterenle en beleving var het arbeldsongeschikt-z1jn ultaluitend volstrente dusterns heerst. Met name de 1.1terature over de beleving van werkloosheld en over de sevolger van (chrondehe) zlekte bledt inzicht in de faetten van het leven zonder werk van arbeldsongeschlkten, de mogel1 fk van belang z1jn.

Een sumier overzicht van deze aanknoplngspunten volgt in hoofdstuk 2 . 
Woten bit hoofastuk 1

*.

1. Hieronder 1 in begrepen alle werkenden (ultgezonderd meewerkende gezinsleden, schalieren en studenten die minder dan 15 uur per week werken), alle tijdelijk nietwerkenden (door zlekte, staking e.d.) en alle personen zonder werkkring, die werk zoeken. Voor een exacte definitie: CBS walkstelling 1971.

2. Nadere gegevens en clyfers zidn o.a. te vinden $1 \mathrm{n}$ Ph1lipsen (1979) en 1n CBS-publicaties zoals soodale maandstatistieken, arbeldskrachtenteling 1975 en 1977 . compendium gezonahe1dsstatistieken 1974 en 1970.

3. Het onderscheld tussen tijdel1 Jk en langdurig a beldsongeschlkten 1 s nlet "hard". Ten aanzen wan het al dan niet tot de beroepsbevolking behoren geldt als oriterium het al dan niet werk zoeken.

4. Voor de Jaren 1970-1979 was het aantal arbeldsongeschikten met met hoogste arbeldsongeschitheldspercentage $(80-100 \%) 83-85 \%$ wan het totaal. Deze mensen werkten zeker niet. Dok velen met lageme arbeldsongeschiktheldspercentages werkten echter niet. Exacte gegevens daarover zijn niet beschlkbaar. In de klassen 25-55\% arbeldsongeschlkt was 10 à $11 \%$ van alle ultkeringsgenletenden ingedeeld.

5. Economen, politici, journalisten en vele anderen bespreken viljwel daged 1jks de verminderde groelwoet, onevenwichtige betalingsbalans, slechte concurrentiepositie ten opzichte van het buitenland, te hoge arbeidsinkomensquote, te hoge collectleve lasten, 1nflatie, structures verminderie activiteit, en dergelifke. Evenzovele deskunafgen trachten, al dan niet geleld door de berekeningen van het certraal plan Bureau, oplossingen aan te drager: loormatiglmg, nullijn, ombulglngen, verminderde overheldsultgaven, volumebeleld, vergroting van het draagviak, ultbrelding van de quartaire sector en wat dies meer $z 1 d$.

21e onder meen: Van den Broek e.a. 1975, Hoffmen 1976, 
Droppert 1977, Kroon 1977, WRR I977, Bestek '81 en Nota Volumebeled, Den Uyl en Kombrik 1979, FNV 1979, Intermedialr 1980: serie econome en politiek in de jaren zeventig.

6. Het totaal antal arbeldsplaatsen 1 n Nederland, uitgedrukt in het arbeldswolume in manjaren, bleef in absolute zin van 1971 tot 1979 vrlyel gel1yk (van 4.724 .000 tot 4.723.000 met de tusen1sgende jaren lagere c1jfers; mindiae. 4.649 .000$)$.

In percertages ten opzichte van de beroepsbevolung (werkers en werkzekendenj 15 dat echter een afmame van $99 \%$ tot 91 品 en in percentages ten opzichte van de totale bevolking wan 15-65 Jaar een afmame van $57 \%$ tot $52 \%$.

7. Dit geldt vooral voor mannen en niet-gehuwde vrouwen boven de leerplichtige leeftijd. De meeste gehuwde vrouwen zonder baan bultenshuis ontlenen hun matschappeiljke statue enerzijds aan d1e van hun man, anderzljds an hun positie van hulswrouw en opvoedster. Welke laatste doordat zil bulten het arbeldsbestel wordt gereinend, een relatief lage matschappelijke status krijgt.

8. D1t is eer beeld van de matschapp1j de Tonnies (1367) als "Gesellschaft" aanduldt en die Durkhelm (1893) door functionele integratie gekenmerkt det in tegensteliling tot de "Gemelnschaft" respectlevelijk nomatief Geintegreerde samenleving warvoor een samemhangend selsel van a. Igemeen aanwaarde normen en warden typerend wordt geacht.

9. Volgens Beerling wordt de volgende trap in de ontwikkeLing gevorm door de toename van de vrije tjjd, zowel in aantal. uren als in betekenis voor de zingeving van wemands leven. Argezian van de vrag of bli het toenemen wan da vije tijd, op de lange duur, niet overachat heeft. is nu (nog) de arbeldssector voor de samenleving en voor de meeste 1nd1viduen wan groter belang dan de vrljetidasector.

10. Beer1 Ing (1964), Arendt $(1968)$ en Anthony (1977) bieden een weer helder inzicht in deze mater 1 . 
11. Helaas $1 \mathrm{~s}$ er in Nederland nog welnig systematison empirisoh onderzoek gedaan naar de betekenis wan abeid roor het Individu. Bovenalen blifken de scharse onderzoeken op alt gebled niet helemal vergelijubaar wat betreft vraagste111ng, 1temkeuze, onderzoeksgroep en dergelidke. Desondanks, en daardoor des te opvaliender, vindt men in verschillende onderzoeken bljna deselfde percentages woor het aantal werkers, dat werken als plicht beschouwd rond 90\%.

Zle Wippler 1968, Philipsen 1974, Stlchting WetenschappeIijk onderzoek Vakcentraies 1975.

12. Z1e voor een overzicht van studies omtrent ziekteverzulm Smulders 1980. Verder onder andere: Van Mansvelt e.a. 1974, Van Thiel en Wagenaar 1975, Van 2aal 1975b, NWva 1976, Tordo1r e.a. 1978, W1ersma 1979, Kruldenier 1980, Grond en De Pater 1980, en de 11teratur wermeld $1 \mathrm{n}$ par. 1.2.

13. In de bultenlandse literatur 1 s hierover ook weindg te winder. Studies betreffende bljvoombeld "dlsablitty for work" aljn nauweliyks verhelderend voor de Nederlandse stuatie door de grote nadruk op 1) de lichamelijke/mealsche problemen en 2) de flnanclele moellifkhedien, belde voortkomend utt een met Nederland onvergeld Jkbar systeem van loondervingsvoorzieningen (Nag1 1969, Harrs a.a. 1971, Martin en Morgan 1975). 
HOOHDSTUK 2

VRAAGSTELLIKG EN OPLET VAN HET ONDERZOEK

Ir het voorwoord 1 s reeds vermeld dat het onderzoek "leven zonder werk ub twee delen bestat: het basisonderzoek en het definttleve onderzok. Z11. ziJn ldentiek qua populatie, onderzoksopzet en matarlalvergamel1ng; z1j verschilen echter in vraggstelling en deshalve in de bewerking wan het onderzockmateriaal.

De NIPG-rapportages (zie Voorword) doen verslag van het basisonderzok; de resultaten van het definitleve onderzoek worden in het onderhavige manuscript vermeld.

Aangezien de vragsteling voor het definitieve onderwoek een specilleke ultwerking 1 var die voor het basisonderzoek, wordt de latete in par. 2.1 apart beschreven.

\subsection{De uraagste11ng van het bas1sonder woek}

De globale vraagstelling, zoals die ten aanzlen van het leven zonder werk 1 n het 1 gemeen aan dit onderzoek ten grondslag lag, was, zoals in het vorlge hoofdstuk beschreven, gerleht op het spanningsveld tussen nietwerken en het traditionele arbeidsethos. In een desbetreftende NIPQ-werkgroep (z1e Strolnk 1972), wero daarbij de vrabg naar mogelljke "alternatleven voor arbeld" betrokken: kunnen de belangrijke runcties die werken voor de mensen heeft - (zinvalie) tijasbestading. soclam le contacten, erkenning en wardering, zelfontplooling doot andere act 1 itelten overgenomen worden? Het accent lag op een mogellyke compensatle voor de morele druk tot werken.

Men atuilen van het leven zonder werk vam arbeldsongeschlkten werd die vraagstelisng nog a angevuld met de vradg naar de gewlchtsverhouding tussen de problematiek 
van het nlet-werken en dle van de aandoenlmg/handlcap. Een wooronderzoek bil ongeveer dertlg arbeldsongeschlkten wees echter u1t dat de morele problemen van het nlet-werkem en de verhouding ziekte/nlet-werken niet bij voorbaat de belangrijkste aspecten van het leven van arbeldsongeschikten z1jn.

Om het arbeldsongeschikt-zijn in z1Jn wele facetten recht te kunnen doen werd derhalve besloten de vraagstelling te vercumen tot de meer algemene vmag uhoe zlet het leven zonder werk er voor arbeidsongeschikten ult". Darbil werd gedacht aan de volgende te onderschelden facetten: de zlekte/handicap, de tijdsbesteding, de cerlnssituatie en de wijdere sociale omgeving (ram1lie, kennissen, collega"s, "men").

Aan deze facetten van het arbeldsloos bestaan zljn twee niveau's te onderschelden. Allereerst de objectleve sltuatie, dat w1l zeggen de feltelijke omstandigheden zoals deze min of meer objectief kunnen worden vastgesteld. Ten tweede de subjectieve stuatie, dat wil zeggen de omstandigheden zoals ze door de betrokkenen zedeflinleerd worden (Merton 1967, naar W.I. Thomas).

op dit tweede niweau speelt zich de cognitieve en emotionele thterpretatie van de omstandigheden af, het verlenen wan een bepalde betekenis aan wat mer meemakt, warbij naast feltelijke gegevenheden de elgen levensgeschledents en levenspositie, lnclusief gevaelens, Ideeën, normen en waarden, een rol spelen. In het bijzonder moet wat dit betreft gedacht worden aan de visie op het oude werk en op werken in het a lgemeen.

zeker in het onderzoek, warbij de gegevens berusten op via interviews verkegen utspraken, ziln deze twee nuveaus noolt te schelden; de feltellyke zaken worden 1 mers slechts weergegeven zoals ze subjectief worden gezien. Toch dient het onderscheld wel gehandhaafd te worden.

Dit onderscheld speelde een rol blj de verdere predisering van de vraggtellyg. Bij die preclserlng 1 s tevers 
var belang sereet de viste op het arbeldsongeschtht2lin als proces, als en veranderijk verschljnsid. Wlak na ret ophowden met werken zlet het arbeldsloos bestar van arbetdsongeschikten er In vele opzichten allicht ander" ut dan gerume tijd later. zo ds de andoening blywoobeld zelden een statisch gegeven, mar lets dat an verbetering of verslechterlng onderhew $1 \mathrm{~g}$ is. D1t 1 mpliceert niet alleen een prettiger of minder prettige gezondheldetoestand, maar ook wisseling in de praktische omstaridgheden blyvoorbeeld wat betrert doktersbezoek, vergekeringseneegkundige controle en fysleke mogelijkheden tot tijdsbesteding. Het proceskarakter van het arbelasongeschikt-gijn ult zich ook in de wiselende 1deeen omtrent de duur ervan: men ziet het als en tijdell Jke onderbrekling war het gewone arbeldsleven, of als en defintleve nleuwe levensfase.

Afgezien van het feit dat het ene individu meer zal. nelgen natr de ene en een ander nar de andere visie, varleert per individu in de meeste gevalien de duurperceptle watrschljnilfk in tijd.

Bovendien is het veranderende gezicht van het arbeidsongeschikt-gijn te zien in de mogelijkheid om eraan te wennen. Zelfs al zou er in de objectleve situatie niets veranderen, dan nog wordt de subjectleve situatie anders als men eraan gewend rakt of erin heeft leren berusten.

op grond wan bovenstaande overwegingen werd de algemene vraagstelling voor het bastsonderzoek als rolgt verder ultgewerkt:

1. warult bestagt de concrete leefsituat1e var arbeldsongesohikten op versch11zende momentien?

2. hoe beleven arbeldsongeschikten die situatie, wat is bun houdirg tot en waarderling van de elementen dadrin op versold lende momenten?

De sub I senomde vrag richtte all op de zlekte, het gezin, de omgeving en de tijasbesteding.

De vrabateluling sub 2 betrof, nast een oordeel ower dese concrete levensomstandigheden, tevens de mentrig 
over het vroegere werk en de houding ten anzlen van werken in het algemeen en de beleving van het arbeldsongeschikt-zijm in $z$ 'n totalitedt.

Wellicht ten overvlaede $z 1 \mathrm{j}$ vermeld, dat deze vragsteling ultsluitend betrekking had op het meidsongeschlikt-zijn en nlet op het arbeidsongeschlkt-worden.

Dat w1 zeggen, dat het onderzoek niet gemicht was op de oorzaken van het ophouden met werken of van het niet bervatten van het werk. Wangelfsprekend $1 \mathrm{~s}$ dit niet volledig los te zien van de bovengenoemde aspecten van het arbeldsiloos bestaan; de achtergronden en oorzaken vam het arbeldsongeschikt-ajn en -biliwen vormden echter als zadanig geen onderwerp van studie.

De vraagstelling was in haar bovenstaande formuleming ultarukkelijk gericht op een beschrijving van het leven zonder werk van arbeldsongeschikten. In bet basisonderzoek werd dan ook niet naar verklaringen gezocht en evenmin getracht eventuele theorleèn te toetsen. Wat het eerste betreft: het zoeken van verklaringen komt in het deflutieve onderzoek arn de orde. Ten aarzien van het tweede: theorleen ten aanzien van het arbeldslaos bestaan in het algemeen en dat van arbeldsongeschikten in het bijzonder $z i j n$ er (nog) nauwejijks, mede doordat tot op heden te welnig systematisch onderzoek op dit terrein is verricht. Vooral het arbeldsongeschlkt-zijn is zelf nog nauwel1 $1 \mathrm{ks}$ als wetenschappel1jk probleem gesteld.

Vanzelfsprekend neemt dit echter niet weg dat bif de opzet van het onderzoek en de daarbij gebrulkte vragen$11 \mathrm{sst}$ werd ultgegaan van in of meer theoretische verwachtinger en veronderstelingen, voortkomende ult de prakt1Jkervaringen van velle mensen die zich met arbeldsongeschikten bezighouden, alsmede ult het vooronderzowk en ult de literatur betreffende de gevolgen van werk20osheld en (chronlsche) zlekte, de twee elementen warult het arbeldsongeschikt-zijn is opgebouwd. Tenelnde enlg inzicht te verschaffen in het brede scala 
Wan verschijngelen dat het onderzoek bestrijkt, wordt dege 11terature hier in grote 11 men weergegeven.

\section{Literatur betrefiende de gevolgen van werkloosheld}

De wetenschappelidue belangstelling voor de werloosheld in de Jaren dertig betrof vooral de psychologische Bevolgen van de werkloosheid. Men was primair geinteresseerd in indluluele psychische reacties, in gevoelens en tettudes. Het gearag van de werklozen en hun relatie tot hun omgeving merden als 111 wotratie van die reacties gesien.

In een overzicht van de werkloosheldsstudies tot 1938 rubriceren Elsenberg en Lazarsfeld (1938) de gevolgen wan werkloosheid vanult deze psychologlsche optiak. Wanneer men bij onderzoek raar de gevolgen van werkloosheld minder nadruk w1 leggen op de lndividueel psychologische reacties en meer op de levensseren warbinnen de reacties zich voordoen en ap de concrete objectieve veranderingen die daarir optreden, voldoet de rubricering var Elsenber en Lazarsfeld niet. Toch bleden zij bij de lnvuling van de rubrieken duldellyke araknoplngspunten voom een voor dergelijk onderzoek adequate Indeling van werkloosheldsgevolgen. De door hen vermelde onderzoeksresultaten, waaronder die ult het beroemde Dle Ambeltslosen won Marlenthel (Lazarseld en Leisl 1933) tonen aan dat werkloosheld

- psychologlsche reacties veroorzakt: bljvoorbeeld enotlonele instabliteft, Gevolens van minderwatedghe1d, Introverthe1d, apathie, berusting, nervositeit, bltterine1d, wanhoop;

- de tijdsesteding beznvioedt. Vermeld wordt een toename van lezen en bloscoopbezoek (TV was er toen nog niet) en van "stratgedrag" als praatjes maken, naar anderen kijken en wachten tot er lets gebeurt;

- Veranderingen in het gealn met zich neebrengt, zowel in de concrete gebeurtenissen in het gezin als span- 
ningen, ruzles, statuswerlies van de werkloze, soms leldend tot echtschelding. Ook molilykheden me en ven de kinderen worden genoema;

- de relatle met en de bouding tot de omgeving verandert: men trekt zich terug en voelt zleh buitengesioten uit de samenleving, men wordt ontevredener met werkgevers, en het economisch bestel. Elsenberg en Lazarsfeld noemen echter ook afwljkend gedrag in termen van criminalitelt, bultenehtelifke relaties en moreel werval in het algemeen.

Het spreekt vanzelf dat niet alle werlozen identlek reageren op de werkloosheld. Elsenberis en Lazarsfeld noemen als invioeden op de sprelding van de genoemde gevolgen: leeftijd, sexe, soclaal-economische status, mate van flnanciele achterultgang, persoonlifkheld en de duur van de werkloosheld.

Global blifven ook de studies naar werkloosheldsgevolgen vam na 1938 binnen het hier geschetste kader. overigens zijn er zeker in Nederland opvallend weinig dergeligke studies verschenen, In tegenstelling tot analyses van de oorzaken en spreiding wan de werkloosheid.

Bake (1960) concentreerde zlch op het belang van de t1jd ten aanzien van de aanpassing van het gezin aan de werkioosheid van de man. H1j onderscheldde v1jf opeenvolgende fasen (van tijdelijke stabllitelt via desorganisatle tot een nleuw evenwicht), warvan de rolverdeling tusser man en vrouw, zijn status in het gezin, de gezamenlijke gezlnsativiteiten en het optreden nar bulter de indicatoren ziJn. Het belang van de rolverdeling in het gezin, mar ook van de rulmere soclale rollen van de werkloze, wordt door Cohn (1978) ook arngetoond ten aanzien van de "selfstisfaction". Deze is t1jdens de werklooskeld lager dan tijden het leven met werk, mar de mate van ontevredentield wordt in belangrljke wate bepald door de beschlkbarheld van alternatiewe zinvol Beachte rollen. 
Ir dez studes was tot dusverre onvermeld gebleven, of ten hoogste impliclet aan de orde, dat de genoemde negatleve gevolgen van werkloosheld slechts zo errstig kunner alj door hat grote belang dat arbeld in het Individuele en matschappelijke leven heeft. Ovesen (1977) stelt zeer nadrukkelljk dat de psychlsche gevolgen van wekloosheld ontstaen doordat er een breuk optreedt in de ortwkkeling van de identiteit, in de zelfrealisatie, die wijwel ultsiultend door arbeld wordt gewoed. Zig acht dit de belangrijkste betekenis van werken, naast het leveren van inkomen, structur in de t1dd(abestedine), soclale contacten en dergelijke, hoewel $z 1 \mathrm{~J}$ het wegvallen van die functies ook als negatieve werkloosheldsgevolgen noemt.

Dat het wegvallen van het werk niet allë́n negatlef gewardeerd hoeft te worden, knjJtis bij Van Wezel (1977) meer dan terloopse andacht. Als voordelen van werkloosheld noemen de door hem ondervmagde. werklozen: writheid en tija voor zichzelf, tifd voor echtgenote en gezin, uitrusten/siapen/relexen, geld krljgen zonder werk en bljverdienen. Als nadelen worden vermeld: geestelijke en lichamel1jke spanningen, doellooshe1d, gevoel van ultschakeling uit de matschapplj en soclaal isolement.

Dit overzicht van de 11teratuur betreffende de indviduele gevoligen van werkloosheld 1 s weliswar nlet volledig, het geeft echter wel aan binnen welke dimensles van het leven zonder werk het werkloosheldsonderzoek zlch heeft afigespeeld: tijasbesteding, gezin, wijdere soolale omgeving, persoonlijkhe1d, globale warder.lng van de werkloosheld en de invloed van onder meer de dutr der werkloosheld op dit alles.

Wat hierblj ontbreekt is een nadere ultwerking van de visie op werken als medebepalende factor voor de beleving van het niet-werken. Hoewel ovesen $(0.0$.$) wel het$ belang erkent van de centrale plats van werken in het Indlviduele leven voor de beleving van het nlet-werken, geeft zif niet aan via welke meer specifleke betekents 
sen van werken die invioed zich doet gelden. Wvemin besteedt 21 a andacht aan de vroegere werkervaringen.

\section{Literatuur betreffende de gevolgen van de zlekte}

Overzlet men de literatuur omtrent de gevolgen van ernstige en/of chronische ziekte of handicap dan is ook daarin het onderscheid tussen psychische reacties, de relaties in het gezin en de wifdere soclale omgeving terug te winden. De tijasbesteding komt meestal nlet expliciet aan de orde, doch slechts lmpliciet in verband met de fysieke belemmeringen tot activitelt. Evenzo wordt werken slechts zijdelings beschouwd als "lets dat nlet meer kan".

Chodoff (1962) noemt als psychologische ziektegevolgen en veranderingen in de persoonlijke levenshouding: egocentriciteit, hypochondrie, apathie, agressie (onder meer door afhankel1jkhe1d), angst, verklelning wan de belangstellingssfeer, ontkenning; vluchtgedrag (als bij rouw) e.d.

Shontz (1962), siller (1969) en Llpowsk1 (1970) w1jzen op dit soort reacties als "coplng styles", afhankel1jk van de betekenis die men aan de zlekte toekent: als straf, ultdaging, waardevolle ervaring, zwakte, opluchting, verlies. Z1j stellen ultarukkelijk dat de zlekte een positieve betekents kan hebben en dat de reactie op de negatieve beteken1ssen posit1ef kan z1jn: men kan het zlekteprobleem in gunstige ain oplossen.

Belangrijk in het gezin $1 \mathrm{~s}$ de nieuwe afhankelijkneldstelatie die door de ziekte ontstats de noodaak tot een nleuwe rolverdeling tussen de zleke en de andere gezinsleden, veranderingen in de besl1ssingstructur en de gezamenlijke activitelten en veranderingen in het toekomstsperspectief wan met gezin (M1chels 1968, Ludwig en collette 1969).

De veranderde rolrelaties in het gezin, mar vooral ook daarbuten, aijn onderwerp van de vele studes naar 
de zikterol. Parsone (I95I) definierde de ziekterol a e erste in termen van rechter en plichten (bljvoorbeeld om nitt te werken resp. verzorging te aarwaraden). Van belang of de vastiteling var de thhoud der rechter en pliften van de zleke, zowel door hemelf als door zis omgeving, acht mer de ard van de andoening, de enot, de zichtbarheld en vooral en effectieve commnicatie tussen de zleke en wijn omgeving. Dit latste bepalt in grote mate de legltimtelt wan het gedrag wan de zleke (Kassebaum en Baumann 1965, L1ps 1969, Petron 1969, Haber en Smith 1971, Zahn 1973).

Haber en Smith wijzen op het belang van commuleatie en Hederijase aanassing vooral bij de "d1sabl11ty-rol" dat wil zegen de verwachtingen ten aanzien van het gedrag van degene die niet volledig is hersteld. Hig kan gedeeltelijk wel en gedeeltelifk niet nommal, als gezonde, functioneren doch zijn preclese (on)mogelijkheden ziln niet exident.

In alt verband zijn ook de beschouwingen wan Goffman (1963) en cratty (1967) over het effect wan rysleke kenmerken op de relaties met anderen van belang.

Bovengenoemde literatur heeft mede bepald welke Globale facetten van het leven zonder werk van arbeidsongeschlkten en welke onderwerpen darbinnen in het onderzok aandacht zouden krljgen: de aandoening, de tijasbesteding, de gezinssituatie, de omgeving, de visie op het oude werk en op werken in het algemen.

De 1 in de 11teratur bedoelde psyahische reactes op de aandoming an het niet-werken ziln exter bulten beschouwing gelaten omdat de vraggstiling primalr gerlcht was op de meer tastbare levensomstandigheden. Bovendlen zou bestudering van de psychisohe reactes, zo zij enige an wlier hebben, grondiger moeten zijn dan in het kader var dit onderzoek mogel1jk was.

Het spreekt echter wanzelf dat in het onderzoek de persoonllike reaotle van de arbeldsongeschikten op het 
leven zonder werk niet geheel afwesig is. Voom zover deze niet wervat 1 s 1 in de mening over de verschillende facetten van het leven zonder werk, komt dj tot ustdrukking in de beleving van de situatie-in-zin-geheel in termen van de sat1sfactie met de concrete omstandigheden en wan een meer algemene lewenshouding.

Al deze onderwerpen, de levensomstandigheden en de bel sving ervan, zulien in hoofdstuk 3 nader worden ultgewerkt.

\subsection{De wragsteling van het defindtieve onderzoek}

Doel var het bastsonderzoek was het nast elkar beschrijwen van de verschillende aspecten van het arbeidsloos bestaan, zonder aan het é̉n meer beteken1s te hechten dan aan het ander.

Voor het definltleve onderzoek geldt dit echter niet meer. De vraagstelling is nu geconcentreerd op de beleving van de situatie in $z^{\prime n}$ geheel, als resultat van de aandoening, de wisie op (het) werken, de gezinsomstandigheden, de relatie met de omgeving en de tijasbesteding.

De keuge van een op de beleving gerichte vraagstelling komt voort ult verschillende overwegingen.

In de eerste plaats 1 s de vrag of het aj dan niet "1s uit te houden" een zeer cruclale vraag bly ledere situatie die arwljkt van wat men in het algemeen als normal. en wenselijk beschouwt en/or waran men nlet gewerd 15 . Negatlef gesteld, in de verwachting dat de niewwe onstandigheden moeliljkheden opleveren, luidt de vrads b1 wvoorbeeld: "red je het een beetje", "1s het vol te houden", "walt het erg teger". Posltief gesteld, doelend op waaschijnilfk plezlerige ervarlngen: "bevalt het een beetje", "1s het leuk", "zou je nog anders wllen", e.d. Vragen die alle van toepassing ziln op het leven zonder werk van arbeldsongeschlkten, en die alje verband houden 
met de beleving van de nleuke situatle alles blj elkatr genomen. Alle te onderschelder facetten van de nleuwe stuatie ziyn, hozeer missahien ook interessant op zlehzelf, onderdeler var het geheel en dracen als zodanig zowel feltelifk als gevoelsmatig bly tot (de ervaring van dat ghed. Ieder ootdeel over het arbeldsloos bestaan, zowel dat van de direkt betrokkenen, de nietwerkers, als wan degenen de "er tegen aan kijken" is impliciet en expllatet gebaseerd op de verschlilende apecten ervan en op en afweging van dife aspecten ter opzichte var elkaar.

Hilop slut de tweede overweging aan die ertoe leldde dat in het definitleve onderzoek de aradacht primalr gerloht wordt op de belewing van het leven zonder werk.

ledere beschrifving, van welk fenomeen dan ook, wint aan 1nzichtelijkheld wanneer de beschreven elementen in een bepalde onderldnge verhouding worden geplatst. Het geheel krijgt daarmee relief. Er is dan echter wel een central gezichtspunt nod1g, een criterium, aan de hand warvan die onderlinge verhoud1ng, dat relatieve belang wordt vastgesteld.

In termen van dit onderzoek: de betekenis van de aandoening, het gezin etc. ten opzichte van elkaar en ten opzichte van de totale situatie moet worden bepaald aan de hand van de bijdrage die deze elementen leveren aan de beleving van het lewen zonder werk in " $z$ geheel.

Voor de keuze van de beleving als uitgangspunt voor refore studle geldt nog een derde, meer praktisch, argunent. zij bledt lmmerg de mogelijhtheld om de zeer grate hoeveelheld vragen en daame mogellyke analyses en resultaten, die het enquate-meterlat oproept, op averzichtelijke en zinvalle wijze te ordenen en te beperken.

Een dergelijke ordenting zou vanzelfsprekend ook kunnen pletivinden op grond van en ander criterlum, bljvoorbeeld het werkems of de tijdsbesteding. Dat zou echter 
een keuze impliceren tussen de verschiliende aspecten van het arbeldsloos bestaan, warvoor, afgezlen van eventuele persoonllyke voorkeur van de onderizokster, op voorhand geen steekhoudend argument anwezis is. De keuze voor de beleving als ardentngspincipe bij de verdere analyses van het onderzoekmaterial lifkt derhalve, op grond van het eerste argument, zinndger.

De vragstelling kan dan in eerste lnstantie als volgt seformuleerd worden:

1. a. hoe wordt het leven zonder werk door arbeldsongeschlkten op verschillende momenten beleefd;

b. wardoor wordt dle beleving vooral belnvloed?

Deze vraag kan (evenals die van het basisonderzoek zowel met transversal als met longltudinal onderzoek worden aangepakt. Gekozen 1 s voor een comblnatle van belde (wie par. 2.3) waardoor de vraagstellymg voor het definttieve onderzoek kan worden ultgebreld met ankele speciflek longltudinade vragen.

2.a. Welke veranderlngen treden er in de loop der manden op in de beleving en de achtergronden ervan;

b. zilin er aorzaken voor de veranderingen in de beleving aan te w1jzen;

c. wordt de beleving van het langdurde arbeldsongeschikt-zijn beinvloed door de ervaringen, zoals die na een kortere periode zijn wastgelegd?

3. Z1jn er op een bepaald moment versch11len te constateren (in de beleving en de daarbij relevante factoren) tussen degenen die langdurig arbeldsongeschikt zullen blifven en degenen die na enjge tijd weer aan het werk gaan?

\subsection{De materiaalverzamel1ng}

Wat betreft de methode van onderzoek stond het intervlewen van de direkt betrokkenen, de arbeldsongesahikten, voopop. 
In principe waren er drie mogelifheden om in deze interwiew het proces van het arbelosloos bestagn te be1. 10iter:

- In en éenmalig interview vragen stellen over zowel de situatie op dat moment als in de tijd datryor: een momentopname met terugblik.

Vragen naar het verleden trengen echter de nodige complicaties net zich mee vanwege de vertroebelingen door vergeetachtigheld, werdringing, verkleuring etc. " weardoor dit geen Ldeale methode 1 s (Haggara 1960).

- Het érnmalig tegelijkertijd interviewen van groepen mensen, die verschllien in de dur van de arbeidsongeschlkthe1d: de zogenaande transversale methode. Deze levert in zoverre inzicht in processen, dat men uitspraken kan doen over de stand van zaken op wersch1llende momenten. B1jvoorbeeld: Langer arbeldsongeschikten wardexen hun sltuatie positiever dan korter arbelasongeschikten.

- Het meerdere keren interviewen van dezelfde mensen: de longltudinale methode. Hierdoor kan men ultspraken doen als: langdurlig arbeldsongeschlkten warderen hun situatie positlever dan toen ze nog nilet zo lang arbeldsongeschikt waren (Goldstein 1968, Wall ama W111.ams 1970 ).

Het spreekt vanzelf dat de longltudinale methode de voorkeur veroliende. Er kleven echter aan het ultslutend gebruiken van deze methode enige bezwaren, waronder als belangrijkste de volgende:

a. E 21 In voomlsnog geen theoretsche averweglngen die de keuze bepalen van de momenten in het arbeldsloos bestan (in de maanden wanaf de eeriste werk-loze dag), warap gelnterviewd zou moeten worden.

De keuze die hierin zou worden gemakt, moest daardoor op praktische gronden berusten (zie par. 2.4), warbij bet var tevomen echter niet zeker zou zijn; of de heuze met het oog op het optymal wichtbaar maken van eventuele veranderingen een goede was; 
b. het herhaald interviewen van éen $\mathrm{grcop}$ mensen heert het gevaar in zich, dat de orderzoekresultaten voor een (onbekend) gedeelte toegeschreven moten worden aan de specifleke bijzanderheden wan de groep. Het 1s bljwoorbeeld niet ondenkbag dat blj arbelasongeschikten die in Jamuari het werk neerlegden andere a andoeninger, tifdsbestedingen e.d. een rol spelen dan b1j degenen die in junt met werken ophlelden (z1e par* 2.4 ).

Bovenstaande bezwaren van het ultsiultend gebrulk wan de longltudinale methode leldden tot het beslult deze te combineren met de transversale, waarbly retraspectieve vragen ultsluitend voor de terugolik nar het leven vobr het arbeldsloos bestaan gebrulkt zouden worden.

In concreto betekende dit een onderzoek, bestaande ult interviews in drie fasen, die de mogel1 jkheld bleden tot transversale én longltudinale analyse.

In de eerste fase werden interviews gehouden met drie groepen arbeldsongeschikten die onderling 6 maanden verschllden $1 \mathrm{n}$ de duur van de arbeidsongeschikthe1d, name11jk 4, 10 en 16 maanden (gerekend wanat de eerste arbeldsione das).

In de tweede fase, een half jaar later, werden weer arie groepen gelnterwiewd, warvan étn nleuke, 4 maanden arbeldsongeschikt, en twee uit de vorige fase, 10 en 16 maanden arbeldsongeschikt.

De derde fase, weer na een half jaar, bevatte interviews met twee groepen u1t de vorlge fase(n), nu 10 en 16 manden a beldsongeschikt.

Deze onderzoksopzet $1 \mathrm{~s}$ in het orderstande schema overzlchtel1jk weergegeven. Op de keuze van de halfjarlijkse intervalien on de drie momentem in het arbeldsioo bestaan, warop werd geinterviewd, wordt iri par. 2.4 ingegaan. 


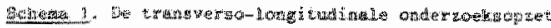

\begin{tabular}{|c|c|c|}
\hline \multicolumn{3}{|c|}{ 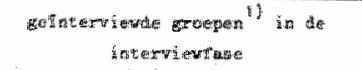 } \\
\hline 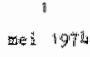 & ${ }^{2}$ & $\begin{array}{c}3 \\
\text { Exi } 1975\end{array}$ \\
\hline 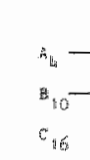 & $\begin{array}{r}3_{16} \\
-B_{10} \\
-B_{16}\end{array}$ & $\begin{array}{l}\rightarrow D_{19} \\
\longrightarrow A_{16}\end{array}$ \\
\hline
\end{tabular}

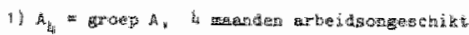

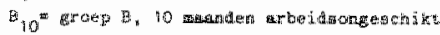

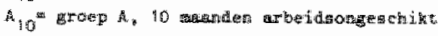
ans.

Groep A 1 s de centraje groep wat betreft het longltud 1nale deel van het onderzoek; van deze respondenten $21 \mathrm{ln}$ 3 1nterwiew beschikbaar, zodat men de gegevens van drie verschillende momenten in het arbeldsioos bestaan met elkaar in verband kan brengen.

De analyse van het transversale onderzoekdeel in de eerste fase makte het mogel1jk de kelize van de momenten Ir het arbeldsloos bestaan op zijn warde te toetsen, zodat eventueel bljstel11ng had kunnen plaatsvinden ten aanzlen yan de laatste twee momenten in het longlutulnale onderzokgedeelte (zie pag. 41 , sub a).

Door de mogelijkheid de analyses betreffende groep A a an te vullen met de amalyses var de groepen $B$ en $D$, wordt het probleem van de gropsspeciflcitelt ondervangen (zie pag. 41, sub b). Er bleken overigens geen systematische versonilien te bestan tussen $D_{4}$ en $A_{4}$, tussen $B_{10}, A_{10}$ en $\mathrm{D}_{10}$ en tussen $\mathrm{C}_{16}, \mathrm{~A}_{16}$ en $\mathrm{B}_{16}$. D1t $1 \mathrm{~s}$ trowwens alleen te constateren doon het interval tussen de versch1llende 1ntervlew-fasen gelljk te stelien aan het interval tussen de versohlliende momenten in de arbeldsongeschiktheld, wardoor de groepen respondenten per fasw worden gekarakteriseerd. 


\subsection{De samenstelling var populatie en steekproes}

De beslissing, dat er gegevens verzameld zouaten worden van mensen die vier manden, een half of een heel Jaar langer arbeldsongeschikt zouden zin, berustte voor een groot deel op praktische overweglngen.

Deze hingen naw samen met het beslu1t de onderzokpopulatie te beperken tot arbeldsongeschikten, die een ultkering genoten krachtens de zlektewet ( $2 W$ ) of de wet op de Arbeidsongeschiktheidsverzekering (WAO) voor sover deze wetten werden ultgevoerd joor de bil het aemeenschappelijk Administratiekantoor (GAK) angesioten bedrijfsvereningen en het Sociaal Fonds Bouwnijuerheld $(\mathrm{SPB})$.

Deze beslisingen, alsmede andere gegevens betreffende de samensteling van de populatie er de steekproef woor het basisondergoek zijn ultgebreld beschreven in bijlage I. In deze paragraaf zullen slechts de essenties darran worden vermeld.

1. In de eerste plaats dient dan te worden vastgesteld dat de keuze van de verschillende interviewmomenten in de longltudinale onderzoeksopzet samenviel met de keuze wan de verschillende subpopulaties in de transversale opzet: achtereenvolgens interviewen b1 4,10 en 16 maanden betekende een verdeling van de totale populatie in drie (4, 10 en 16 maanden) "duurgroepen".

2. De keuze van het eerste interviewmoment (c.q. de eerste anurgroepl werd geleld door de overwegling dat dit zou moeten valien op een tijdstip warop en redelijk antal betrokkenen beseft dat de arbeldsongeschlktheld een langdurlige geschledenls kan worden. D1t in verband met de nadruk op het onontkoombare defintieve karakter wan het arbeldsloos bestaan in a1t onderzoek. Het eerstie interview zou dus niet te snel na het ophouden met werken moeten plaatsvinden. Te lang daarna zou echter evenmin gewenst zijn daar 
het onderzok dan wellcht belanglike elemerten ult het proces van aanpasing en vormgeving aan het arbelabongeschikt-zifn zow oversian. De ultelndeilike kewze wan het eerste interviewmont werd, met inachtreming van het bovenstaande bepara door de wiyze warrop de orderzokpopulatie het meest eenvoudis samengestel kon worden. Dat bleld in dat aansluting werd gezocht bij de admintratieve handeIngen die in het kader var de zlektewet ten aanzien van de zogenaande "10-weeksgevallen" weroen verricht. Herdoor waren ult de administraties van het GAK en het sFB mensen met 10 weken arbeldsongeschiktheid achter zlich relatief makkeilyk op te sporen.

De selectie van potentiele respondenten voor de groeper A en D (zle sohema 1) vond aldus plaats ult $10-$ weeksgevalien. Door de tifd, die gemoeld was met selectle, verzoek om medewerking en steekproeftrekken, lag het interviemoment ra \pm 4 maanden arbeldsongeschiktheid.

3. De keuze van de volgende interviewmomenten of van de volgende duurgroepen, werd bepaald door de gang van zaken betreffende de overgang van de ziektewet naar de Who, die een Jar na de eerste werk-loze dag plaatsvindt. Deze overgang wordt woor de betrokkene meestal gemarkeerd door de mededelingen dlenaangaande door de verzekeringsgeneeskundige, een keuring ter vaststelling, wan het arbeldsongeschlktheldspercentage en/of een brief warin hem dat percentage en de hoogte var de mede daarop gebaseerde who-uitkering worden meegedeeld.

Aangezien mag worden aangenomen dat dit, vooral met betrekking tot de wijge warop de betrokkene het arbeldsongesch1kt-z1jn ervart, belangrlike gebeurtenissen $z i j n$, was een lntervlew ruet te lang ervoor ën een interview niet te 1 ang erna gewenst.

Wat betreft het Interviewen ervoor $\mathrm{lag}$ het voor de hand aan te slulten bij de administratieve handelin- 
gen die \pm 9 maanden na de eerste werk-loze dag plaatsvinden in verband met de adviesanvmage elnde wechtija.

De selectie van potentlele respondenten ult degenen die 9 maanden arbeldsongeschikt zijn (groep B) resulteerde in een tweede interviewmoment na 10 manden arbeldsongeschuktheld. H1ermee lag, gezlen de noodzaak de twee intervallen gelijk te houden, ook het derde 1nterviewmoment en de selectle van groep c vast: na 16 maanden arbeldsongeschikt-z1jn.

Van het interviewen van meer onderzoeksgroepen en op nog latere momenten in de arbeldsongeschlktheld is vooral afgezien in verband met de wens het onderzoek nlet te lang te laten duren, mar eveneens op grond van de kosten en de beschikbare vrouwkracht.

4. De onderzoekpopulatie, hierboven al enlgszins om11jnd, 1s met toepassing van verschiliende criterla nog verder beperkt. Deze criteria betroffen gesiacht, leeftijd, burgerlifike staat, aandoening, national1teit en prognose ten aanzien van werkhervatting. De redenen hiervoor zijn ulteengezet in bijlage I.

Dit heeft ertoe geleid dat de populatie van het onderzoek bestaat uit:

Behuwde Nederlandse mannen van 25-55 jaar, d1e ap grond van bepaalde nlet-psychlsche aandoeningen 4, 10 en 16 maanden een zlektewet- respectlevelijk WAO-u1tkering genoten via het $G A K$ of het $S F B$, die niet werkten en van wie niet vaststand dat zil binnen de onderzoeksper lode weer aan het werk zouden gaan.

De selectle van deze populatie ult de administratles van het $Q A K$ en het $S P B$ vond plast in april 1974 (groep A, B en C) en in oktober 1974 (groep D). De Interviews voor de eerste twee fasen werden gehouden 1n mespectievelijk mel/juni en november/december 1974 ; de derde fase 1 s in me1 1975 afgewerkt.

5. Twee factoren bleken, onder andere op grond van het wooronderzoek, van zoveel belang voor de aampasing 
en de vormeving an het arbefdsloos bestaan, dat het noodzakellyk werd geoordeeld te zorgen dat deze 1 in woldoende warlatie in de steekproep aanwez zouden zin: leeftudu en beroep.

De Invloed van de leeftijd op de varlabelen in het onderzoek betreffen bljwoorbeeld de mening over de herstelkang en de kans op merkerwating; de viste op arbeld, de gezinssamensteliting en dergelijke.

Beroepen $z$ Ju in principe op twee wlizen in te delen: op grond van de soort werk, blyvoorbeeld hoord-of handarbeld en op grond wan het beroepsnivean, dat wil zegeen het milleu- of statusapect van het beroep. Deze twee lnctingen zifn echter zeer wel te combinereir, hetgeen ook in vele beroepenclassificaties gebeurt. 1)

Dat er invloed ultgat wan het soort wew dat men doet op de wlye warop men het werken en het nietwerken ervart is duldelifk. Daamaast blijkt uit onderzoek op sociaal-wetenschappelijk tertein teikens weer het belang wan het soclaal-economisch nlveal, op welke manier ook gedefinleerd en geoperationaliseerd.

B1j a-selecte steekproeftrekking uit de totale populatie was te verwachten dat veel meer ouderen dan Jongeren en hand-dan hoofdarbelders in de steekproef zowden valien omdat doze in de arbeldsongeschikte populatie veel meer voomkomen.

om een evenwlcht1ger leef $t 1 j d s-$ en beroepsverdeling te bereiken werd besloten de populatie te stratiflceren nar lewtijd en berop, dat w1 zegsen de populatie op te splitsen in een aental verschiliende lext1jds- en beropsoategorden en ult elk van deze categonlean een a-selecte stuekproef te trekken.

Herto werd leetiJd in drie categoriesn verdeeld: 25-39 Jaar, 40-49 Jaar en 50-55 jaar en beroep ook in drde categorleen, dat w1 zeggen twee voor het GAK: hoofd-en handarbeld en éen voor het SFB: handarbeld. De resulterende steekproeven $z 1 j n$ nlet apart geanaly- 
seerd, maar samengevoegd tot én totale steekproef". Een wantitatieve beschrijuing van de onderzoekpopulatie en de steekproeftrekking voor het basisonderzoek is te winden in bijlage $I$.

Voor de duldelijkheld dient opgemerkt te worden dat de term steekproef in fielte alleen betrekking heert op het samenstelien van de groeper $A_{4}, D_{4}, B_{10}$ en $C_{16}$ (schema 1, pag. 44). De overige groepen z1jn zonaer inmenging van de onderzoekster tot stand gekomen. Immers, alle respondenten die in de tweede en derde fase nog arbeldsongeschikt waren en gelnterviewd konden worden, maken deel uit van wat de afgeslankte of uitgedunde steekproef genoemd zow kunnen worden. Voor zover de term steekproef (1n hoofdstuk 3) nog gebezigd wordt, heeft zij betrekking op het totaal wan de oorspronkelljke èn de ultgedunde steekproven. Als zodanig bevat de steekproef dus verschiliende respondenten twee- of ariemaal. 


\section{Moot bil hoofdstuk 2}

1. Instituut roor Toebepaste Soclologle, Beroepenklapper, Hijmegen 1973. De lndeling van de beroepenklapper bestakt ult 6 statusriveaus, warin als belangrijkste bepalenae factoren oplelding en soort werk (hard vs. hoofa) zijn opgenomen. De lagste twe groepen womden doon ongeschoolde en geschoolde handarbelders gevorm, de vier hogere door lagere, midelbare en hogere employé's, zelfstandigen, academide.d. In dit onderzoek wordt voomamel1jk het onderschesd tussen hoofa- en handarbejd gehanteerd. 


\section{HOOFDSTUK 3}

\section{BASISGEGEVENS ROND STEEKPROE EN VARIABELEN}

\section{I. De concretisering van de vraagstelling}

De in paragraaf 2.2 geformuleerde vragstelling voor het definttieve onderzoek was nog niet gespeciflceerd ten aanzien van de desbetreffende momenten in het leven zonder werk. Na de populatie-omschrljwing kan deze specificatie als volgt gegeven worden.

1.a. Hoe wordt het leven zonder werk door arbeldsongeschikten beleefd na 4, 10 en 16 maanden arbeldsongeschikt zijn?

b. Waardoor wordt die beleving vooral beInvloed?

2.a. Welke veranderingen treden er op van 4 tot 16 maanden in de beleving en de achtergronden ervan?

b. $z 1 j n$ er oorzaken voor de veranderingen in de beleving aan te wijzen?

c. Worat de beleving van 16 manden arbeldsongeschikt-z1jn bernvioed door de ervaringen na 4 maanden?

3. Z1jn er na 4 maanden arbeldsongesch1ktheld versch11len in de beleving en de daarbij relevante factoren te constateren tussen de arbeidsongeschikten die het 16-maands interview zulien meemaker en degenen die hun werk hervatten na het 4-maands interview?

Hoewel de eerste vraag met behulp van zowel transversale als longltudinale analyses is te beantwoorden, zal alleen de transversale worden u1tgevoerd. De beschikbare aantalien zijn daarblj zo groot mogelijk (zle pag. 57, tabelien 3 en 4 ). De vragen 2 en $3 \mathrm{z} 1 \mathrm{jn}$ ultsilutend met. longltudinale analyses arin te vatten.

Deze twee analysevormen lmpliceren een essentiele splitsing van het totale onderzoekmateriaal in verschillende groepen: duurgroepen bestaande uit respondenten die 4 or 
10 of 16 manden arbeldsongesehikt 21 in en driemal Eednterviewden: respondenten die achtereenvalgens ma 4 , 10 èn 16 manden gelnterviewd $213 n$. De ordening van de steekproef 1 s hermee echter nog niet voltoola.

3.2. De subgroepen naar leeftid, beroep en aandoentng

In par. 2.4 1 s reeds wermeld dat het leven zonder werk var arbelasongeschikten mede onder invioed van leeftijd an beroep sestalte krljgt. Belde factoren spelen niet alieen een rol bij de woormalige werkervarinEen, mar bijwoorbeeld ook blj de tijdsbesteding (Wippler 1968, knulst 1977) vöor het ophouden met werken en het $11 \mathrm{gt}$ voor de hand dat van hun inwloed ook daarna wel het een en ander merkbar 1s. De stratiflcatie van de steekproef naar leettijd en beroep was erop gerlcht deze Invloed optimal te kunnen vaststellen.

Een derde factor, die wan evident belang is bij de ervaring van en vormgeving aan het arbe1dsongeschikt-zijn is de andoening, als objectleve beperking van de gedragsmogejifkheden en als subjeatief ervaren handicap.

De in het basisonderzoek geconstateerde effecter van leeftild, beroep en aandoenlng leldden mede tot de volgende vragen ten aanzien van het definitieve onderzoek:

a. Wat is de invloed van leeftija, beroep en aandoening op de beleving wan de arbeldsiloze situatile en op de verschlliende daarblj relevante factoren?

b. Wat is de invloed wan leeftild, beroep en ardoening op de amenhang tussen de beleving en de daarbif relevinte factoren? Anders geformuleerd: hoe zlet deze samenhang erult al met de inwloed van leeftijd, beroep en aandoening rekening gehouden wordt?

Bij belde vragen 21 in niet alleen de effecten van deze arie basiskenmemken afzonderlijk aan de orde, maar ook die van comblnaties darvan.

Ter beantwoording van deze vragen staan in principe 
twee wegen open: correlatierekentng (voor vraag b. partiele) en splitsing van de onderzoekpopulatio in verschillende leeftijos-, beroeps- en a andoenlngscategorieền.

De keuze $1 \mathrm{~s}$ in eerste instantie op de tweede mogelijkheld gevalien, daar deze vooral met betrekking tot de tweede vraag het voondeel bledt dat het effect van leeftijd etc. zlohtbaar worat in de al dan nlet tussen de categarieèn verschillende rrequentleverdelingen van en samenhangen tussen de varlabelen bij partiele correlatierekening worden de leeftijds-etc. effecten "onzlchtbaar" over de totale steekproef verrekend). 1)

Voor de indeling van de steekproef in leeftijds-, beroeps-, en aandoeningscategorleen werd de eerste stap gezet met het besilut de categorieen var deze drie factoren niet los wan elkar te hanteren, maar te combineren; een beslut op grond van de overweging dat de relatie tussen de onderzoekvarlabelen gezulverd atende tie worden van de gezamenlijke effecten van leeftijd, beroep en aandoening.

Tenelnde en nlet te groot aantal categorleer te krijgen (van belang in verband met de omvang van de totale steekproef) werden de arle factoren gealchotomiseerd, welke procedure tot acht siamengestelde categorieün le1dde (zie pag. 55).

Leeft1jd is gesplitst in een groep van $25-44$ jaar en een van 45-55 jaar. De grens tussen belde 1 s gebaseerd op de frequentleverdeling der leeftijden in de duurgroepen. De leeft $1 \mathrm{Jd}$ is de leeftifd bij het ophouder met werken.

Beroep is verdeeld in hand-en hoofdarbeld, op grond van de beroepenclassflcatie van het Inst1tuut voor Toegepastie soclologie (z1e hoofdstuk 2, noot 1). Het gaat om het beroep dat men ultoefende totdat het werk werd neergelega.

De aandoenlng is voor dit doel geclassiflceerd als een beperking van specifiek de beweglngsmogellykheden dan wel als een antasting van de algemene lichamelljke 
condite. De tegensteling tusien deze soonten aandoeningen 1 get dulde1jkst bly ziekten als arthritis, rheuma en hernla, respectieveliff bif tiekten van hart en bloedvaten, van het spisgverteringsapparat en van de ademaling

Gezien het beslult tot dichotomiseren zijn ook de over1ge in thet onderzok opgenomem aandoenungen aran deze twee categoriex toegerekend en wel natr gelang hun symptomeri over het algemeen neer speciflek als bewegingsbeperking arn wel meer aigemen als antasting van de conditie, van het withoudingsvermogen of wan het lichamelijk welbevinden kurnen worden operevat. 2 )

In onderstand overzich is aangegeven lit welke diagnosegropen de zo gerormeerde aandoeningscategorieën beataan. De nummering komt overeen met de coderingen die het $G A K$, het $\mathrm{SF}$ en de OMD hanteren. In bijlage I stat vermeld waarom bepaalde diagnosegroepen, b1jv. psych1sche aandoeningen, niet in het onderzoek zijn opgenomen*)

Bewegingseperkingen:

VI. Ziekten var zenuwstelsel en zintuligen, woor zover het ontstekingen van het centrale zenuwsteiseil (022), hersenvilezen en bloedvaten (023), multiple sclerose $(024)$, andere zlekten van het centrale zenuwstelsel (026) en ziekten van zenuwen en perirere ganglia $(027)$ betreft

XIII. ziekten der bewegingsarganen

XV. ongevallen

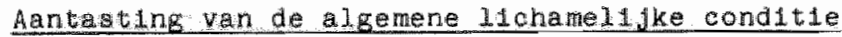

I. Infectiezlekten

II. Endoorlne stoornissen, stofwlselings- en voedingswekten

IV. Zlekten van bloed en bloedbereldende organen 
VI. Zlekten van zenuwstelsel en zlntulgen, voor wover net ep1lepste $(025)$, oog- en oorzlekten $(028$ en 029) betreft

VII. Zlekten van het c1rculatie-apparat

VIII. Ziekten van de ademalingswegen

$X I$. Zlekten van de spljswerteringsomganen

$X$. ziekten van het urogentialsysteem

XII. Ziekten van ruid en onderhulds bindweersel

XVI. Andere en vag omschreven ziektebeelden

Het spreekt vanzeli dat deze classiflcatie van diagnoses niet betekent dat in leder Individueel geval de aandoening uitslutend of overwegend specipleke beweglngsmoeliljkheden dan wel algemeen onwelbevinden met zich meebrengt.

De Indeling in de twee globale diagnosegroepen is gebaseero op de statistische algemeenbeld van de hoofdaccenten der diverse diagnosegroepen, en als zodanig toepasbaar op de steekproef, niet op individuen.

Door combinatie van de dichotomier van leeftijd, beroep en aandoenlng kan de steekproef In acht cateroreên onderscheiden worden:

1. jonge handarbelders met een aantast1ng van de ajgemene 11 chamelijke conditie

2. oude handarbeiders met een aantasting van de \&lgemene lichamelijke conditie

3. Jonge handarbelders met bewegingsbeperkingen

4. oude handarbeiders met bewegingsbeperkingen

5. Jonge hoofdatbelders met een antasting van de algemene Itchame11Jke conditie

6. oude hoofdarbelders met een aantasting van de algemene lichamellyke conditie

7. Jonge hoof dambe1ders met bewegingsbeperkingen

d. oude hoofdarbeiders met bewegingsbeperkingen

Deze acht categoriečn kenmerken evenzovele voorwarden waarbinnen het antwoord op de vraagsteliling moet worden gegeven. Met andere woorden: de acht comblnatles speci- 
pleeren de onderzokgroepen tot acht subgroepen voor wellke leder apart de vaagselling geformuleerd en beantwoord moet worden.

De ult te voeren analyses kumen voor de verschiliende aubroepen verschlliende resultaten opleveren, warmee dan de invioed van leeftijd, beroep en aandoening is aangetoond. ze kunnen echter ook avereenkomsten tussen de subgroepen zlohtbar maken, waarmee kan worden vastgesteld dat leeftild, beroep en aandoening géen merkbaar effect op de desbetreffende varlabelen en de samenhangen daritussen hebben.

\section{3. De steekproef geteId}

In het voorgaande zlyn verschlliende verdelingen van de totalie steekproef (oorspronkelijke + afgeslankte) de revue gepasseerd: duurgroepen, driemal geinterviewden en subgroepen. Hun onderlinge verhoudingen z1jn van Broot belang voor (een helder lnz1cht $1 \mathrm{n}$ ) de analyses, die ter beantwording wan de vraagsteling zullen worden uitgevoerd.

De drie duurgroepen bestaan ult alle respondenten die 4 , respectleweljJk 10, respectievelijk 16 maanden arbeldsongeschlkt zign. De duurgroepen bestaan uit pespectieve$111 \mathrm{k} 75 \%$, 496 en 387 arbeldsongeschikten. Een aantal van her makt deel uit van twee of drie durgroepen. De duurgroepen vormen de basis voor het transwersale deel van het orderzoek (z1) de vragetelling sub 1, pag. 41). De driemal geinterviewden ( $($ w 74$)$ vormen de basis voor het longlitudinalie onderzokgedeelte (vraag telling sub 2 en 3). De driemal gelnterviewden maken deel ult van leder der arle duurgroepen.

De acht subgroepen near leeft1jd, beroep en aandoening kummen zowel blnnen de duurgroepen als binnen de ariemal gelnteviewden worden onderschelden.

De onderverdeling van de totale steekproef kent derhazve 
twee niveaus: eerst die in duurgroepen en driemal geinterviewden en daarna de splitsing in subgroepen.

De kwantitatieve consequentles van het een en ander z1jn in de tabellen 3 en 4 weergegeven.

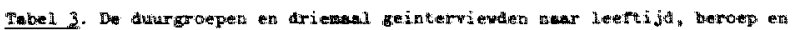
andoerting

\begin{tabular}{|c|c|c|c|c|c|c|c|c|}
\hline \multirow{3}{*}{ 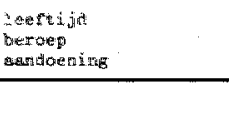 } & & & duture & pepen & & & \multirow{2}{*}{\multicolumn{2}{|c|}{ 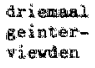 }} \\
\hline & \multicolumn{2}{|c|}{$1.44 a^{2}$} & \multicolumn{2}{|c|}{2.110 trand } & \multicolumn{2}{|c|}{$3 .(16$ mand $)$} & & \\
\hline & \&它可 & x & abs & 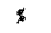 & $a b s$ & 5 & labs & 4 \\
\hline 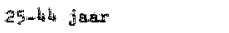 & 100 & 52 & 235 & 47 & 17\% & 46 & 28 & 318 \\
\hline $45-55 \mathrm{jagar}$ & 349 & lik & $26 \mathrm{l}$ & 53 & 210 & 5 & 46 & 62 \\
\hline pandarbe id & 595 & 76 & 412 & 83 & 307 & 79 & 61 & 82 \\
\hline noordarbeit & 162 & 24 & 8t & 17 & 80 & 21 & 13 & i. 8 \\
\hline bewering beprering & 4.56 & 60 & 307 & 642 & 246 & 6 hit & 4: & 5,5 \\
\hline conditieverwijutering & 301 & 30 & 189 & 38 & 14: & 36 & 33 & 45 \\
\hline Trotand & 9757 & 100 & 396 & 100 & 387 & 100 & $p_{\text {hir }}$ & 100 \\
\hline
\end{tabular}

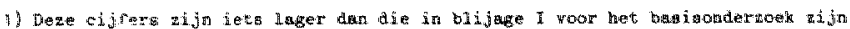

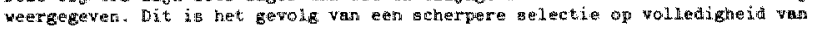
die gegerems.

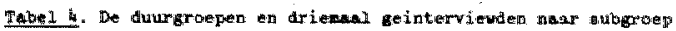

\begin{tabular}{|c|c|c|c|c|c|c|c|c|}
\hline \multirow{3}{*}{ subromenen } & \multicolumn{6}{|c|}{ dutreroepen in } & \multirow{2}{*}{\multicolumn{2}{|c|}{ 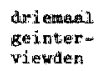 }} \\
\hline & \multicolumn{2}{|c|}{$1 .(4$ and $)$} & \multicolumn{2}{|c|}{$2 .(10 \sin )$} & \multicolumn{2}{|c|}{$3 .(16 \mathrm{mind})$} & & \\
\hline & athes & w & abs. & 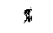 & abss & 1 & $\mathrm{abag}$ & 20 \\
\hline H. jong hand conditite & 102 & 13 & 61 & 12 & $4 z$ & 11 & 10 & 13 \\
\hline 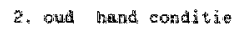 & 197 & 15 & 89 & 19 & 60 & 15 & 16 & 2 \\
\hline 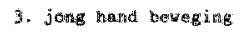 & 220 & 29 & 134 & 27 & 103 & $2 \%$ & 13 & 18 \\
\hline 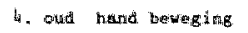 & 156 & 21 & 128 & 26 & 102 & 26 & 20 & 3 o \\
\hline 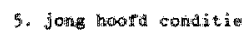 & 39 & $\$$ & 14 & 3 & 12 & 3 & 3 & $\mathrm{i}_{4}$ \\
\hline 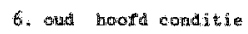 & 3 & 6 & 29 & 5 & 27 & 7 & 4 & 3 \\
\hline 7. Jonf boor bayging & 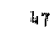 & 6 & 26 & 5 & 20 & 5 & * & 3 \\
\hline 8. oud hoof beurging & 3.3 & 媅 & 19 & 4 & 21 & 5 & 4 & 5 \\
\hline Tot.8nit & 757 & 100 & 496 & 100 & 3 斯 & 100 & 74 & Hort \\
\hline
\end{tabular}


Het $1 \mathrm{~s}$ duldel1 $1 \mathrm{k}$ dat het antal hoofarbelders (subgroep $5 \mathrm{t} / \mathrm{m}$ b), ondanks de stratiflcatie van de populatie, Bering 1s, zeker bly de drlemal geinterviewden.

De verkiarlne hiervan ligt voor de hand: hoofdarbelders maken een pelatier klein deel ult van de biJ het CAK, het $S \mathrm{~PB}$ en de GWD geregistreerde arbelasongeschikten. De voor dit onderzoek gehanteerde selectleprocedure (zle b1ylage ' $I$, met name sub $3 . f)$ beperkt dit aanbod nog verder en terslotte $z i j n$ er relatief veel hoofdarbelders die door werkhervating na het eerste of twoede interview niet aan een derde intervlew toekwamen.

Het gevolib van deze onderbezetting van hoofdarbelders 1. dat de vier subgroepen warin $z$ is $z$ In oncerscheiden in verdere aralyses meestal samengevoegd zulien worden ori het probleem, dat een klelne $N$ bij verschiliende statistische technieken zou opleveren, te ondervangen. In volgende paragrafen zal derhalve worden gesproken over 5 subgroepen: wer handarbeldersgroepen en één groep hoofdabelders, tenz1 anders 1 vermeld.

\subsection{De herkomst van de steekproer}

De in het onderzoek opgenomen arbeldsongeschikten komen ult seheel Nederland, zly het riet in geliyke mate ult alle windstreken. De selectle van respondenten 8 schiedde doom alle perlfere resp. districtskantoren van het GAK en het SFB (10-weeks "gevalien" en adviesaanvrager elnde wachtoija; groepen $A, B$ er $D$, schema 1 pag. 44) wit de centrale WAO-admintstratie van de cemeenschappedinke Medsche Dienst te Amsterdam (Groep 0 ). In onderstamde tabelien is de provinclale en reglonale herkomst van de durgroepen en de driemeal geinterviewden weergegeven. 


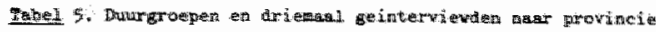

\begin{tabular}{|c|c|c|c|c|c|c|c|c|}
\hline \multirow{3}{*}{ proviation } & \multicolumn{6}{|c|}{ duurgropepey } & \multirow{2}{*}{\multicolumn{2}{|c|}{ 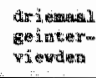 }} \\
\hline & \multicolumn{2}{|c|}{$1,(\mathrm{~d}$ and $)$} & \multicolumn{2}{|c|}{2.1100 mats } & \multicolumn{2}{|c|}{ 3. (1) } & & \\
\hline & abs & $y$ & at) & 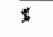 & abs: & 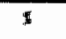 & abs & $\$$ \\
\hline Gromingen & 27 & 4 & 啔 & 5 & 28 & 7 & 3 & 4 \\
\hline Friesilana & 40 & 5 & 25 & 5 & 9 & 2 & 5 & 7 \\
\hline Drenthe & 20 & 3 & 19 & 4 & 11 & 3 & 3 & 4 \\
\hline Dverijugeli & 44 & 6 & 34 & T & 38 & 10 & "T & 9 \\
\hline Gelderland & 65 & 8 & 5.5 & ถ 1 & 45 & 12 & in & 15 \\
\hline Limburg & 75 & 10 & 39 & 8 & 29 & 7 & 3 & إ \\
\hline ancord-Br.ant & 138 & 17 & 86 & 17 & 52 & 13 & 9 & 11 \\
\hline verecht & G & 6 & 23 & 5 & 22 & 6 & 5 & 7 \\
\hline Hioord-Holland & 相车 & 19 & $\pi$ & $\eta$ 崩 & 66 & 17 & 10 & 13 \\
\hline Wuid-Holland & 162 & 21 & 175 & 23 & OH & 22 & 19 & 26 \\
\hline 2eedand & $B$ & $i$ & 5 & i & 3 & 1 & - & - \\
\hline Ratsi & $75 \pi$ & 100 & 496 & 100 & $3 \mathrm{Hat}$ & 100 & 74 & 100 \\
\hline
\end{tabular}

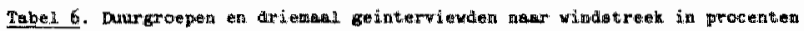

\begin{tabular}{|c|c|c|c|c|}
\hline \multirow{2}{*}{ windistreek: } & \multicolumn{3}{|c|}{ dustemgrowepen } & \multirow{2}{*}{$\begin{array}{l}\text { Artemma } \\
\text { geinter- } \\
\text { vi ewiten }\end{array}$} \\
\hline & A. (hand) & 2. (10 rnd $)$ & 3. $(16 \mathrm{mtad})$ & \\
\hline Woord $(\mathrm{cm}, \mathrm{Fr})$ & 9 & 10 & 19 & 11 \\
\hline Dost (Dr, or, old) & 17 & $2 a$ & 25 & 28 \\
\hline Zuid (MBr, Limb) & 27 & 25 & 20 & 15 \\
\hline 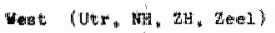 & 田 & 53 & 6 & 46 \\
\hline Totali & 1000 & 100 & 100 & 100 \\
\hline
\end{tabular}

Du1del1jk 1 is dat de Randstao de grootste b1jdrage aan de steekproef levert, gevolga door het zuiden. Uit het hoge Noorden $z i j n$ de minste respondenten afkomstig. H1er zal niet worden Ingegaan op de mogelijke oorzaken van deze regionale sprelding van de arbeldsongeschikten. 
De 1 mpliciete vrag nar oorzaken weht zich lmmers primalr op de gedifferentieerde herkomst van alle arbeldsorgeschikten, en niet op een bepalde selectle darult, zoals de in de onderzoekpopulatie blyoorbeeld door diagnose en prognose wordt beperkt (zie bljlage I). Belangwjker lis echter at er in dit onderzoek geen gegeveng zijn opgenomen wat betreft de werkgelegenhe1d, arbeldamarkt, beroepsberolking, demograflsche kenmerken te. War de provincles.

Welilicht ten overvloede kan in dit verband gewezen worden op het feit dat dit onderzoek zlch niet richt op de oorzaken van arbeldsongeschiktheld. Voor zover ten aanzlen van het arbeldsongeschikt-bl1juen dezelfde factoren escrol spelen als ol het arbeldsongeschikt-worden, zouden deze aan de orde zifn blj de nadere analyse van de arlemal geinterviewden in hoofdstuk 6 .

Van de woonplaats der respondenten 1 s behalve de prowincie wartoe ziy behoort nog Eén ander gegeven bekerid: de urbanlsatiegraad ofwel de mate van verstede11jk1ng. Hierbid is de lndeling wan het CBS gebrulkt (op basis van de 14 e algemene volksteling, 1971).

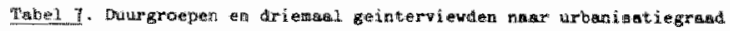

\begin{tabular}{|c|c|c|c|c|c|c|c|c|}
\hline \multirow{3}{*}{ 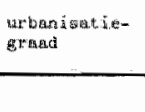 } & \multicolumn{6}{|c|}{ duturgrotopen } & \multirow{2}{*}{\multicolumn{2}{|c|}{ 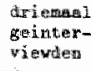 }} \\
\hline & \multicolumn{2}{|c|}{$1,(4 \mathrm{GHEd})$} & \multicolumn{2}{|c|}{$2 .(10 \mathrm{mys})$} & \multicolumn{2}{|c|}{$3 .(16 \tan a)$} & & \\
\hline & 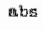 & 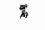 & abas & 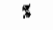 & $a b s$ & 竞 & ebs: & $y$ \\
\hline 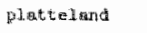 & 759 & 21 & W & 22 & 79 & $2 n o$ & 17 & 23 \\
\hline 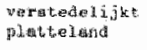 & 786 & 25 & 118 & $a^{4}$ & 93 & 24 & 20 & 27 \\
\hline ateat & $4 \pi 2$ & Sti & 261 & $y_{14}$ & 215 & 56 & 37 & 50 \\
\hline 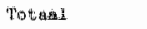 & 757 & 100 & 4,96 & 100 & 397 & 100 & 74 & 100 \\
\hline
\end{tabular}

platteland: meer dan 20 van de manreligke beroepsbevalking behoort tot de agrarlsche beroepsbevolking;

verstedel1jkt platteland: minder dan $20 \%$ van de manre$11 \mathrm{ke}$ beroepsbevolking behoort tot de agrarische beroepsbevolking; de grootse woonkern telt minder den 30.000 Inworers en de gemeente heeft geen ultgesproken reglonali verzorgende functie;

stad: overige gemeenten. 
Rond de helft der respondenten $1 \mathrm{~s}$ afkomstig ult steden, welke vooral in de Randstad zijn gelegen. De plattelandsgemeenten komen in het ooster relatlef veel voor en in mindere mate in het Noorden; verstedel1 is in het zulden relatief sterk vertegenwoordigd.

Overlgens blifken noch de provinclale, noch de al dan niet stedelijke herkomst van de respondenten van belang voor de (relaties tussen de) onderzoekvarlabelen. Be1de kenmerken bl1jven dan ook verder onbesproken.

3.5. De steekpraef en het unlversum van alle arbeldsongeschikten

Vergelljking van de steekproef met het unlversum van alle arbeldsongeschikten in de zlektewet- en WAO-administraties 1 s slechts zeer ten dele mogelijk. Verschillende kenmerken, zoals beroep, burgerl1jke stat, provincie en urbanisatiegraad $z 1 j n$ niet in de statistieken van de GMD, het GAK, het $S F B$ en de averige bedridfsvereniglngen opgenomen. Een belangr 1jk gegeven, de dur van de arbeldsongeschiktheid, kent in die statistieken een andere indeling dan de in dit onderzoek gehanteerde. Dit bec:kent dat de duargroepen (4, 10 en 16 manden arbeidsongeschikt) slechts naar leeft1d en dlagnose kunmen worden afgezet tegen enkele nlet voljedig vergelljkbare duurcategorieern van de zlektewet- en WAO-gerechtigden, zoals die in de statisteken van de zogenaamde omslagleden (deze atat1stleken betreffen $85 \%$ wan alle ziektewetverzekerden) respectievel1 $\mathrm{gk}$ wan de GMD zijn opgenomen: hersteld na 92 dagen/na 183 dagen/nlet hersteld, ultkering bedindigd respectiewel1jk b1j aanwang WAO.

Met andere woorden: de 4 , 10 en 16 maands geinterviewden kunnen vergeleken worden met ultker 1 ngsgerechtigden met een zlektedur van respectievelijk $3-6,6-12$ en $>12$ maanden. 
De bronnen van de gegevens, die in de volgende tabelien verwerkt zijn, zijn de diagnosestatistleken van de bearyjtiverendien van het CBS wat betreft de zlektewetcilfers 1973 en 1974 en de overzichten F3 ult de GMD Jaarverslagen wat betreft de WAO-c1Jfers 1974 en 1975.

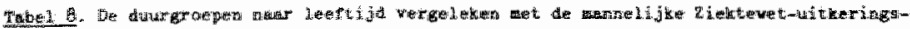

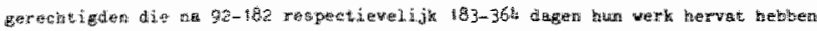

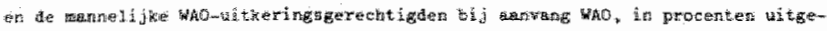
Girute.

\begin{tabular}{|c|c|c|c|c|c|c|}
\hline \multirow[b]{2}{*}{ Leection } & \multicolumn{6}{|c|}{ 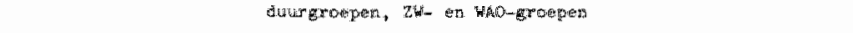 } \\
\hline & 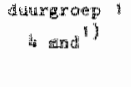 & 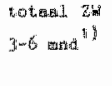 & 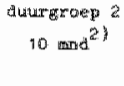 & 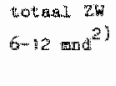 & 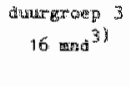 & 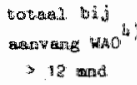 \\
\hline $2 y-2 k$ & 8 & 13.5 & 6.4 & 13.11 & 6.2 & 9. 曹 \\
\hline $30-33^{14}$ & 12.4 & $15+1$ & $3 \times 9$ & 13.2 & 8.0 & 15.5 \\
\hline $35-39$ & 15.4 & $16: 3$ & 8.9 & ib 15 & 15.2 & 13.2 \\
\hline 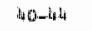 & 18.6 & 1:T.5 & 18.1 & 17.4 & 16.3 & $17+6$ \\
\hline 16 50149 & 21.9 & in $3 \cdot z$ & 23.9 & 18.8 & 25.1 & 20.2 \\
\hline $50-54$ & 24.11 & 30,14 & 28.6 & 28,4 & 29.2 & 29.1 \\
\hline Tatem & 100 & 100 & $1 \mathrm{cos}$ & 99.9 & 100.1 & 100 \\
\hline$\therefore \quad t h$ & 757 & $795 \% 8$ & 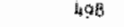 & 3451 & 387 & 21145 \\
\hline
\end{tabular}

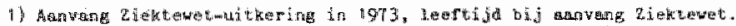

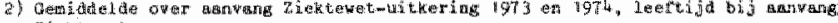
Ziektrewet.

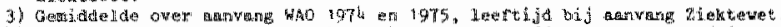

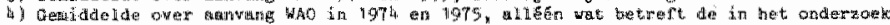

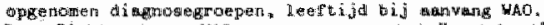

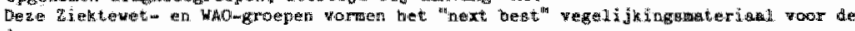
duLuresopen.

Duldelijk 1s, dat in de steekproef minder jongeren en meer ouderer ziln opgenomen dan in de totale zlekteweten WAO-populaties van 25-55 jaar. Een mogel1yke verklarlng hlervoor is de selectle op de te verwachten lange 21ekteduur, dle voor duumgroepen 1 en 2 is toegepast, wardoor veel jongeren (ook al blj het eerste interview) het werk bleken te (hebben) hervat(ten). In leder geval blijkt de beogge oververtegenwoordiglng van Jongeren niet te zijn berelkt. 


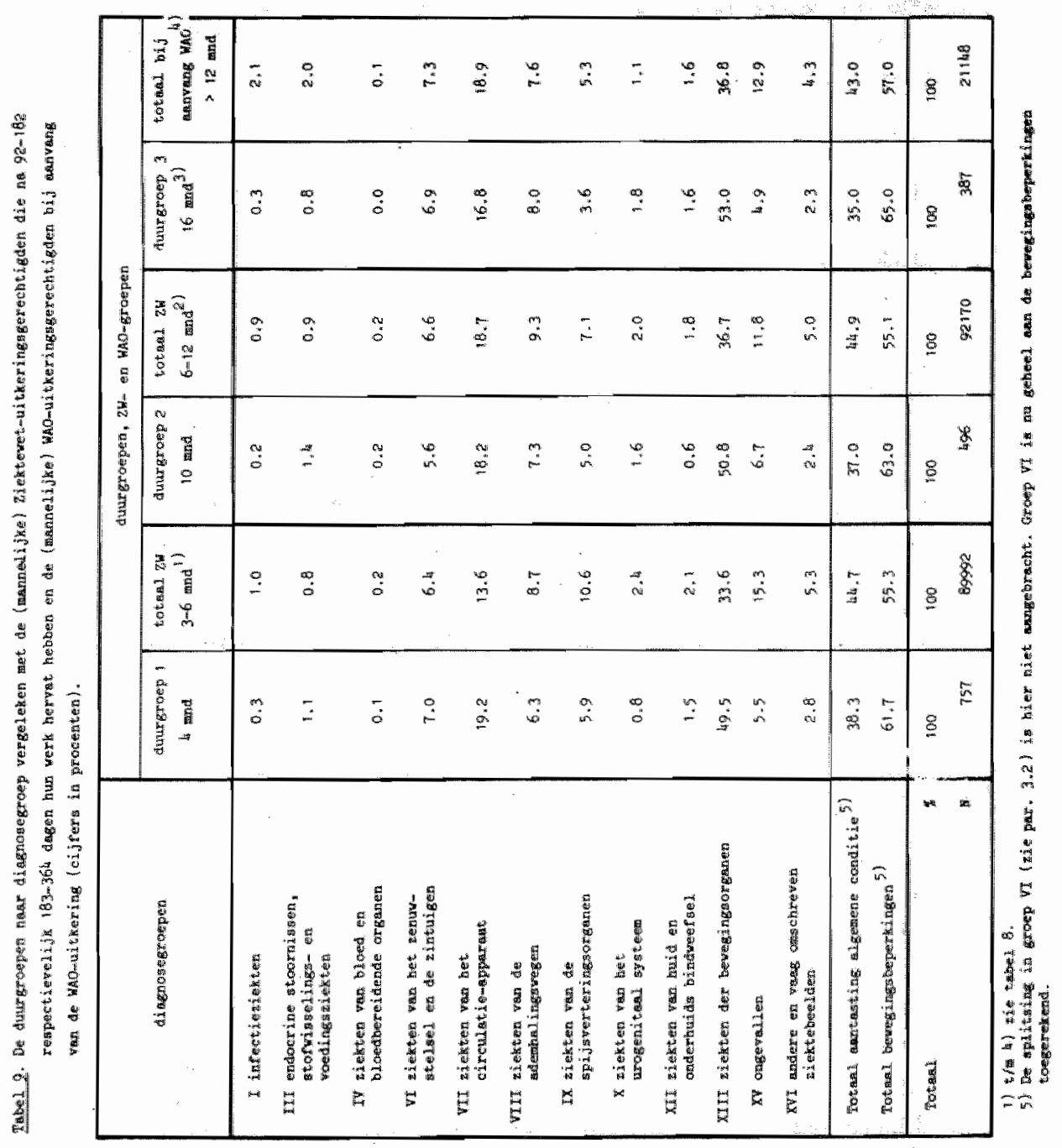


Hoewel deze ciffers met enige voorzlchtigheld bekeken moeten worden 11jken er enkele verschllien tussen de steekproet en het universum te bestaan.

In alle duurgroepen zign zlekten der beweglngsorganen oververtegenwoordigd en ongevallen ondervertegenwoor$\mathrm{d} 1 \mathrm{gd}$.

In duurgroep 1 zi In bovendien relatlef meer ziekten van het circulatie-apparat en relatief minder ziekten van de spljaverteringsorganen opgenomen. .

In totad z1 In in de steekproef de beweg1ngsaandoeningen oververtegenwoordiga.

Met in achtneming van deze ultzonderingen kan echter worden vastgesteld dat de diagnoseverdeling van de in het onderzoek opgenomen dlagnoses voor de steekproef niet essentleel afwljkt van die van alle gereglstreerde arbeldsongesch1kten.

De enlge verklaring woor de aanwezlge verschillen moet gezocht worden in de selectle van de populatie warbij de geschette herstelkans en werkhervatingskans een belangrijke rol speelden.

Deze schatting komt kennelifk niet voor alle diagnosegroepen overeen met de werkelijkheld.

\subsection{De afhankel1jke varlabelen}

U1t de vraagstelling biljkt duidelijk dat de beleving door arbeldsongeschlkten van het leven-zonder-werkalles-blj-elkar-genomen de afhankelijke varlabele(n) voor dit onderzoek bepaalt.

De beleving is op te vatten als een al dan niet bewuste wardering van het arbeldsongeschikt-zijn in al z'n verschiliende betekenissen. Het is dus een samenvattend oordeel over de huldige levensomstandigheden, "warin alle verschlliende ervaringen worden samengevoegd.

Getracht $1 \mathrm{~b}$ b1J de operationalsering van deze athankelijke varlabele geen te weinig gespecificeerde aandul- 
alngen van "geluk" te gebrulken, mar in de 1 tems dulde$11 \mathrm{jk}$ te refereren aan de bijzondere onstandigheden van arbeldsongeschlkten. Tegel1jkert1jd werd echter gepoogd te voorkomen dat een belevingsitem slechts op érn spec1flek aspect van het arbeldsongeschlkt-zijn betrekking zou hebben.

Het resultat van deze pogingen was een indicering van de beleving door acht ultspraken, warmee de respondenten al dan niet hun instemming konden betulgen. 3)

Deze acht ultspraken zijn hieronder vermeld, met de gemlddelden en spreiding per duurgroep.

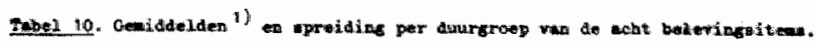

\begin{tabular}{|c|c|c|c|c|c|c|}
\hline \multirow[b]{2}{*}{ Uitapraken } & \multicolumn{6}{|c|}{ duturgroenen } \\
\hline & \multicolumn{2}{|c|}{$\begin{array}{l}\text { A. } 14 \text { mand } x \\
\quad 15757\end{array}$} & \multicolumn{2}{|c|}{$\begin{array}{c}2 .(10 \text { mand }) \\
n=496\end{array}$} & \multicolumn{2}{|c|}{$\begin{array}{c}3 .(16 \cos ) \\
3.67\end{array}$} \\
\hline & gemis. & sprn & gensita. & apr. & genid. & qpr. \\
\hline 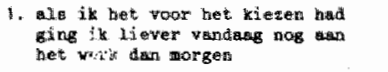 & 3. & 0.8 & 1.4 & 0.8 & 1.5 & 0.8 \\
\hline 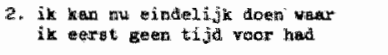 & 2.6 & 1.3 & 2.7 & 1.3 & 2.7 & 1.3 \\
\hline 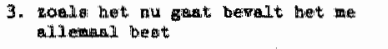 & & 1.2 & 2,1 & 1.1 & 2.2 & 1.1 \\
\hline $\begin{array}{l}\text { 4. wat overweegt, de vorvelende or } \\
\text { de preth a dingen }\end{array}$ & 1.5 & 0.7 & 1.5 & 0.7 & 1.5 & 0.7 \\
\hline 5. It theb het wel man te werduren & 3.3 & 1.3 & 3.1 & 1.3 & 3.1 & 3.3 \\
\hline 6. huth levern it zo slecht nog niet & 3.9 & 1.0 & 3.7 & 1.0 & 3.6 & 1.1 \\
\hline 7. in zide de toekonst somber in & 3.4 & 1.3 & 3.3 & 1.2 & 3.1 & 11.3 \\
\hline 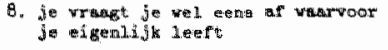 & 3.5 & $1 \cdot 3$ & 3.4 & 1.3 & 3.3 & 1.3 \\
\hline
\end{tabular}

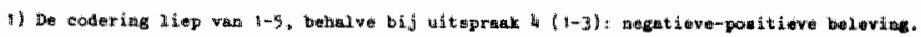

Opvaliend is het versohil twsen de eerste en de tweede vier ltiems: de eerste bieden een duldelijk negatiewer beeld van de beleving van het leven zonder werk dan de tweede vier (ale ook par. 4.1).

D1t ondersche1d in de acht basisitems wordt weersplegeld 
$1 \mathrm{n}$ de ultkometr van de factoranalyses die erop, per aurgroep, ziln ultgeroerd (zle bl Mage II).

Doel an deze aralyses was de reductie van de acht 1 tems tot ean hardzamer antal belevingswarlabelen.

Hoewel de door de factoren verkarde varlantle nlet erg hoog is, kan toch van een duldel 1 jke factorstrueturir gesproken worden: de 1 tems $1,2,3,4$ respectievel1jk 5 , 6. 7 en 8 vormen twee, ook inhoudel1jk herkenbare, dimensles in de beleving van het arbeldsioos bestaan doop arbeldsongeschlkten. Deze dimensies, verder te noemen de satisfactie met de concrete dagel1ykse gang van zaken en de meer algemene levenshouding zullen verder als afhankel1jke varlabelen worden gebrulkt. De waarden van elk var deze variabelen bestaan ult de gesommerde factorscores van de desbetreffende factor. Deze scores hebben een per duurgroep gestandaerdiseerd gemidelde van 500 met een spreiding van 100 .

\subsection{De onafhanke11jke vartabelen}

onder de noemer zlekte, ldeeen over (het) werk(en), gezin, omgeving en tijabesteding zijn in de vragendijat rond 175 vragen met rulm 300 tems opgenomen (zle het $2 \mathrm{e}$ NIPG-rapport) .

Evenalis blj de afhankelijke variabelen is een (forse) reductie tot een handzamer antal varlabelen ultgevoerd. Deze verliep via de volgende procedure.

a. allemeerst vielen ale viagen af die niet bijelk van de drie interviews waren gesteld;

b. vervolgens werden de 1tems getilmineerd, die vaak fout ingevuld, niet goed begrepen, verwarend en/of mult-interpretabel bleken. Wasst de beantwoonding op tich waren de mededelingen van de interviewers hiervaor de basia;

c. daarna 1 door somering van de antwoorden op diverse 1tems een antal variabelen gevormd. Deze samenstel- 
$11 \mathrm{mg}$ gebeurde bij ltems die op grond van hun samenhang, wastgesteld via krulstabelien en correlaties, onder éen, meestal verwachte, noemer te brengen bleken en b1y (grotere aantalien) 1tems, die door midel van factoranalyses tot variabelen werden secomprimeerd en daartoe ook in de vragenlijst waren opgenomen. Deze factoranalyses leverden voor ledere duurGroep nagenoeg 1 dentleke resultaten op.

Deze werkwigze resulteerde in 75 varlabelen, verdeeld over de wijf onderzochte facetten van het leven conder werk van arbeldsongeschikten: ziekte, werk(en), gezin, omgewing en tidabesteding. Deze varlabelen zifn in het basisonderzoek aan nadere studie onderworpen.

d. ten behoeve van het definstleve onderzoek zijn per facet de variabelen opnielw door middel van factoranalyses verder teruggebracht tot in totaal 24 , deels geconcentreerde basisvariabelen. Deze variabelen kunnen worden beschouwd als de, al dan niet globale, aanduldingen van de belangrljkste facetten van het leven zonder werk van arbeldsongeschlkten.

Deze technische reductie van het aantal u1tgangsuariabelen blifkt goed te verenigen met de inhoul van die riabelen. Hun betekenls blijft intact (als zid aan samenvoeg1ng ontsnappen) of 1 s goed te combineren met de betekenis van de andere ultgangsvariabele(n), wadrmee ze tot een basisvartabele zijn samengevoegd. De betekenis

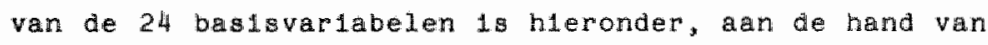
de samenstellende onderdelen, weergegeven.

\section{De (ernst van de) ziekte/hand1cap}

1. Last van de ziekte hoeveelheid last van plyn, niet lekker voejen, vermoeldheld, futlooshe1d; moelte bli het lopen; total aantal lastklachten 
2. behoefte atan mp

last bis telfuerzorgung (wassen abkleden e.d.), behoefte an hulp daably

3. zidekteprognose

verwachting dat aandoening al dan nlet betew wordt

4. gezondine1dsoordeel

mate warin men zchzelf gezond dan wel ziek/gehandicapt voelt

\section{Z1ekte/kerk(en)}

5. verhouding tot wdekte/niet-werken

wat is vervelender: aandoening of niet-werken

6. werkhervat ingspognose

verwachting al dan niet oolt weer aan het werk te Bara

De menlng over het vroegere werk en werken in het algemeen

7. Instrumentede arbedasordentatie

mate warln men de ultspraken "werken is eer noodzakel1 $1 \mathrm{k}$ kwaad" en "werken 1 is niet meer dan een manier om geld te verdienen" onderschrift

8. alternatieve arbeldsorientatie

mate warin men de u1tspraken "ledereen maest kunnen klezen of hil wil werken of niet" en "er $z 1 j n$ een hoop dingen die Je beter kunt doen dan werken" onderschrift

9. orientat1e op arbeld als plicht

mate warin men de ultspraken "je kunt alleen je vilje tija genieten als je ervoor gewerkt hebt" en "door te werken word Je pas een volwaardig lid van de matsohapply" ondersohrigft

10. or Itntatie op arbe1d als centrale waarde

mate warin men de ultspraken "werken is het belangmijkgte in Je leven" en "je moet perse werken om nuttig bez1g te $21 \mathrm{Jn}$ " onderschrljft 
De keuze van deze vier arbeldsorlentatles vergt enige toellchting. In dit onderzoek met zovele andere varlabelen was het ondoen $11 \mathrm{jk}$ om alle verschillende betekenissen van arbeld expliclet, als aparte varlabelen, an de orde te stelien. Daarom is getracht in een aantal u1tspraken de praktische en normatieve inhoud van werken globaal te karakten 1 seren. In de wraag naar de redenen van het werkgemis (varlabele 12) en naar de vervelende en prett1ge kanten wan het arbeldsongeschikt-z1jn (par. 4.i) kwamen de meer specifleke betekendssen van werken, die het niet-werken bemoeliljken, naar boven (zle ook par. 4.2 en 7.2$)$.

11. aard van het werk

mate van afwisseling, zelfstandigheld en elgen invloed van/op het werk

\section{Werkwarder1ng}

mate warlin men werken belangrlyk vindt, het werk mist, plezier in, tevredenheid met en tegenzir tegen het werken had

\section{De relatie met de omgeving}

13. evaluatie omgeving

mate warin men de omgeving meelevend, vriendelijk, geruststellend, bezorgd e.d. vindt, of yulst $1 \cdots$ tegendeei daarvan

14. ervaren stigma

ervaring dat men anders bejegend wordt en/of voor profiteur wordt aangezlen en/of voor lemand de best zou kunnen werken (als hil w1lde)

15. sociale contacten

contactirequentie met familie, viender en kennissen

16. buurt

mate war1n men de woonburt ouderwets gezel11g en persoonl1jk dan wel modern ongezell1g en onpersoonII $k$ vindt 
17. soctale 1solatie

mate aarin men de ultspak "als je niet werkt sta Je elgendulk overal buten onderschridt

\section{De tidabesteding}

18. evaluatie tijastoesteding

rate warla men de huldige tifosbesteding boelend, plezierlig, belangrljk e.d. vindt en de mate warrin men zlch verveelt, de dagen snel. vindt gaan en het Gevoei heeft (n) 1 etg gedaan te hebben

19. usthuszigheid

het al dan niet tochtjes en wandelingetjes maken, café's bezoeken, bly het oude werk gaan kijken, bezoek ontwangen of afleggen en het aantal verschlllende activitelten buitenshuis

20. diversiteit

het al dar riet verrichten van hulshowdelilke bezigheden, klusjes an huls, tuin en auto, creatieve bezigheden (tekenen, muziek, knutselen); frequent1e van "burenhulp" (babys1tten, raad en daad, klussen) en het total aantaj. verschilende activiteiten

\section{De gezinsomstand 1gheden}

21. de sfeer in het gezin

mate warin men de $\mathbb{f}^{\mathrm{f}} \mathrm{eer}$ in het gezin ontsparnen, gezellig, vriendelijk, vrolljk etc. vindt

22. reactie vrouw

mate warin (volgens de man) de vrouw het prettig what dat hig nu thuls 1 s en de toe- of afname van spamingen tussen man en vrouw sinds hil niet meer werk th

23. hudsel1jke takkverdeling mate warin man respectieveligk vroum huishoudelijke taken verrichten, over de ultgeve van het huishoudgeld beslissen en andere geldzaken regelen 
24. Gevolgen inkomensdaling

het al dan nlet hebber van merkbare gevalgen voor de bestedingen van de eventuele daling van het geinisInkomen

\subsection{Gemidelden en spre1ding der variabelen per subgroep en duurgroep}

In tabelien 11,12 en $1321, j n$ voor de 24 onafhanke11 jke en de 2 belevingsvartabelen de gemiddelden en de sprelding opgenomer voor de subgroepen binnen de duurgroepen en woor de totale duurgroepen. Wanneer er signtflicante verschlien $6 \alpha=.05)$ tussen de gemidielde war den van de subgroepen bestaan, is dat in de tabellen aangegeven door middel van een voor het variabelenummer.

Deze versch1lien tussen de subgroepen werden aangetoond met behulp van varlantie-analyses. Dergelljke analyses lieter wok zien dat leeftijd, beroep en arandoening los van elkaar effecten hebben op de varlabelen. quderen, handarbelders en mensen met, beweglngsmoe1l1jkheden hebben het in wele opzlohten zwarder te verwen dan jongeren, hoofdarbelders en mensen net een warwakte cc... tie. Deze verschilien zijn echter niet onverkort in de subgroepverschilien terug te vinden. oudere handarbelders met beweglingsmoeli1jkheden hebben bijvoorbeeld niet met alle facetten van het leven zonder werk meer moelte dan de anderen.

De spectfleke subgroepversch1llen zullen hier niet nader besproken worden, daar $z 1 \mathrm{~J}$, zoals $2 a 1$ bllyken $1 \mathrm{n}$ hoofdatuk 4, ten aanzlen van de beleving van het leven zonder werk grotendeels onbelangrifk $z 1 j n$.

Wanneer de samenhang tussen de varlabelen in aamerk1ng wordt genomen blifken de in bovenstaande tabellen ge- Igraleerde subgroepverschillen namelifk vrijwel ceen van allen atand te houden. 


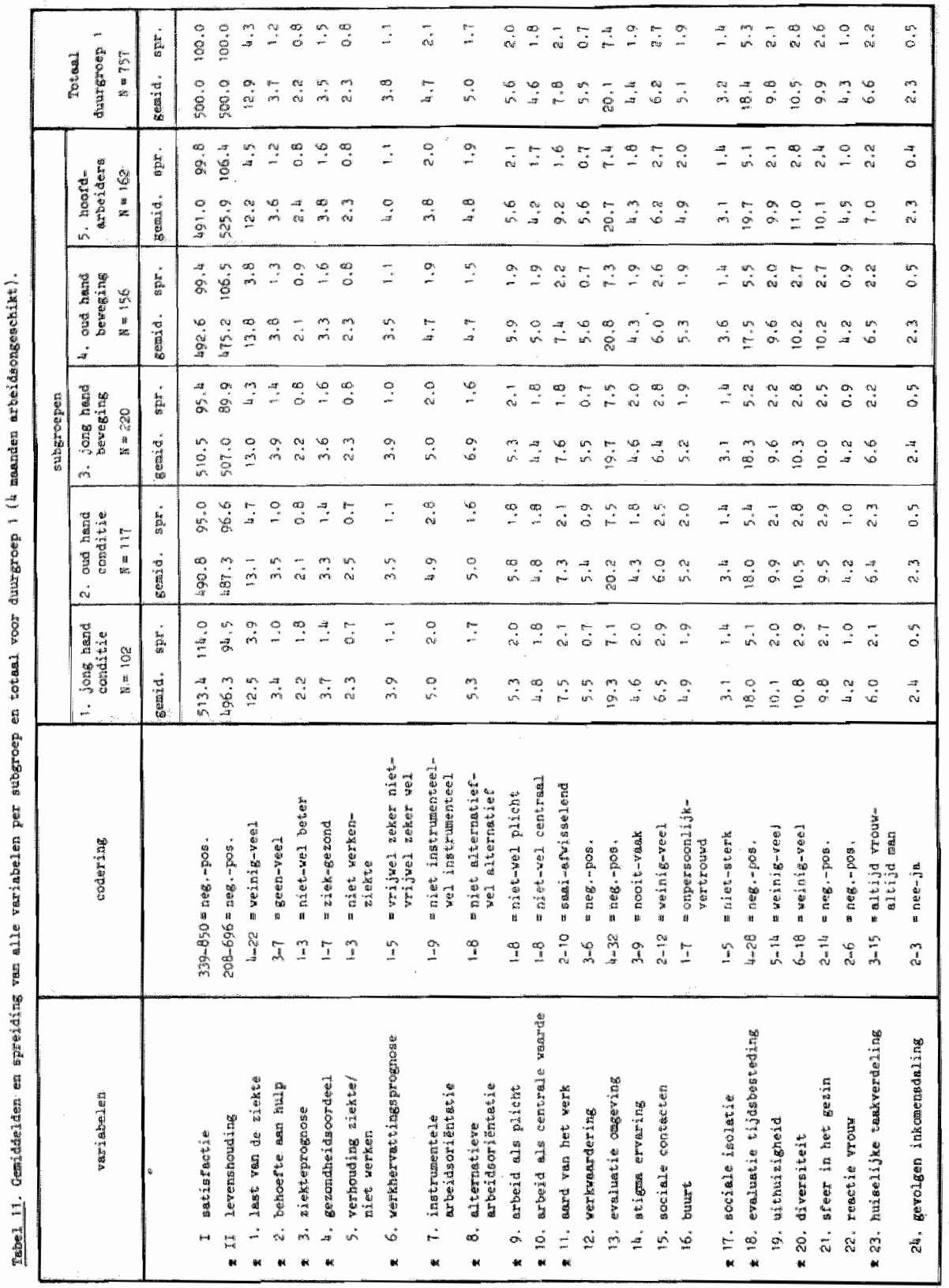




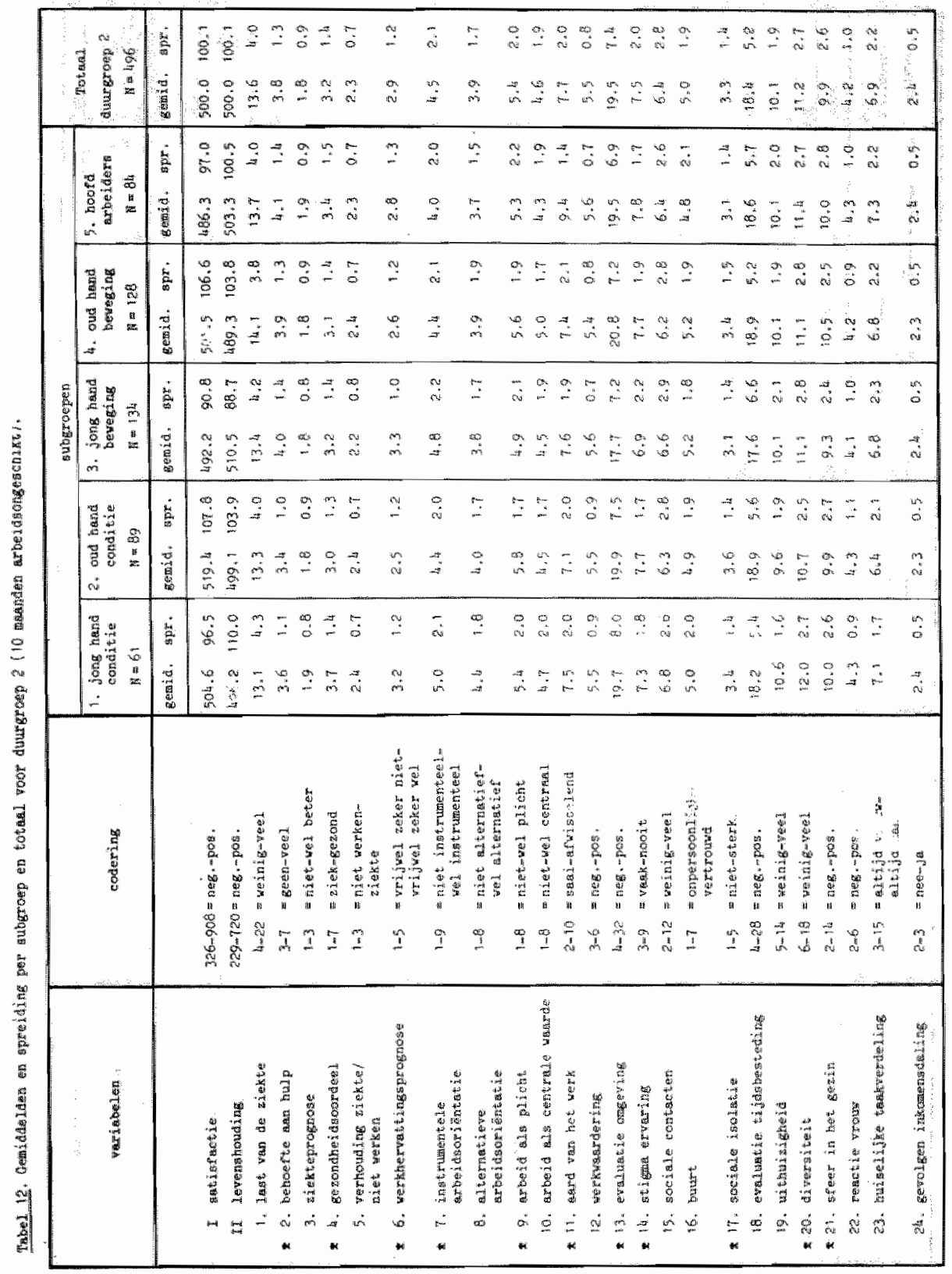




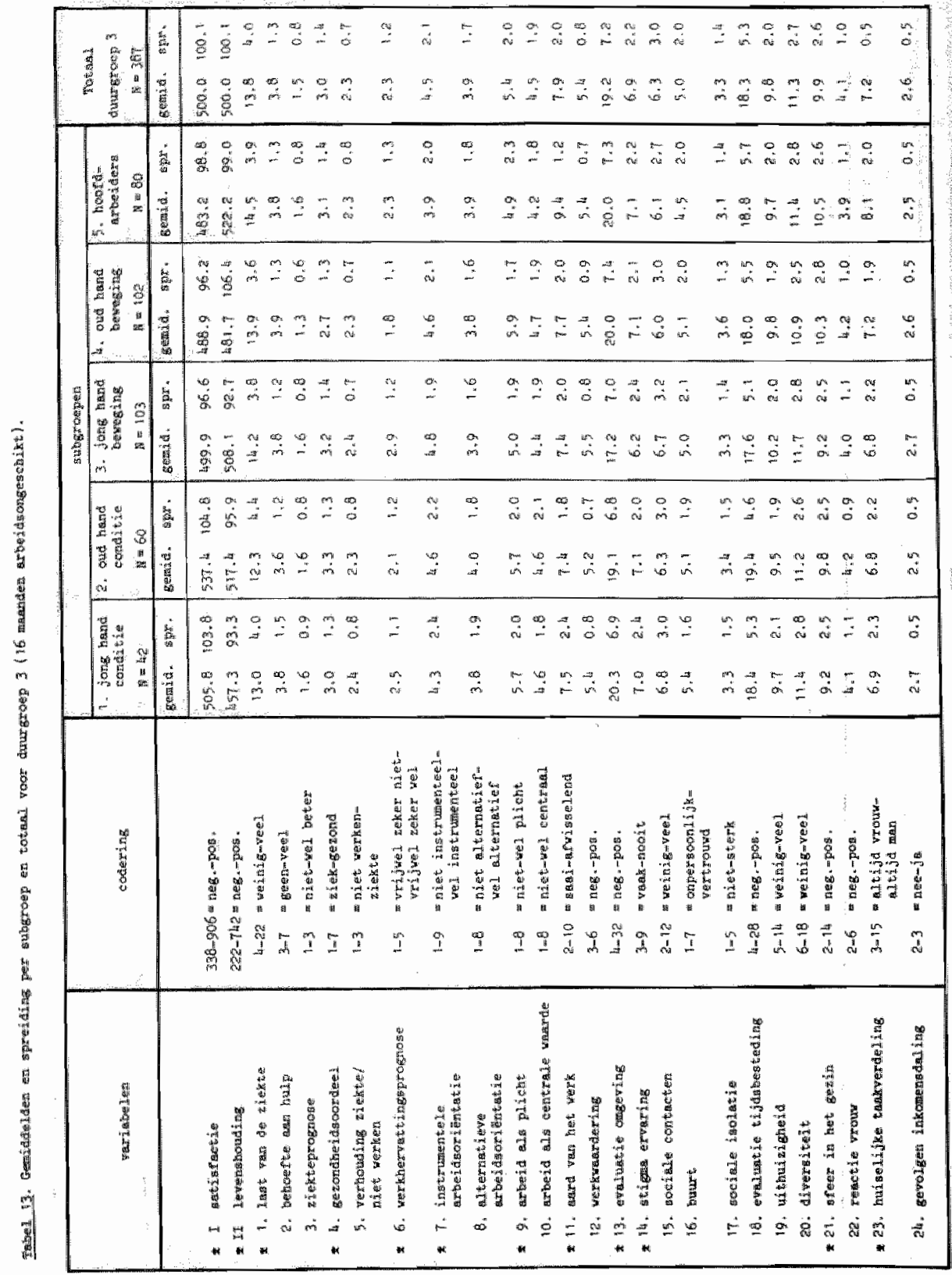


Woten bis noofastin 3

1. Een verband tussen twee varlabelen kan bljwoorbeeld bly enkele leeftijosgroepen aantoonbaar $21 \mathrm{jn}$, doch niet bij alle. Partialierlng naar leeftija zou dan het verband in z1,jn geheel kumnen doen verdwijnen. (Ph111psen 1970).

2. Een andere indel1ng in macrodiagnosegroepen $1 \mathrm{~s}$ van Hogerzel1 (1966). Deze onderscheldt in verband met de afwedgheld wegens zlekte objectleve syndromen, abjectlet-subjectleve en subjectieve syndromen en acult-resplratodre andoeningen. De belangrijkste verschilien tussen de twee eerste groepen zifn de objectieve vaststelbarheld van de kwal en de onontkoombarbeld van de zlekmelding: groot bij de eerste, kleiner bij de tweede. Belde syndromen 1 ijn voor kort èn lang verzulm van betekenls, terwlj de derde vrljwel altijd slechts kortdurend verzulm veroonzakt. De objectieve resp. objectlef-subjectleve en subjectleve syndromen zouden op grond van dit latste in principe in een dichotomle voor dit onderzoek brulkbaar zijn, ware het nlet dat voor vele ernstige aladoeningen (die in dit onderzoek in verband met de te verwachten lange zlektedur de overhand hebben) deze tweedeling niet geheel passend zou zijn. Chronische andoeningen als hernit, arthrits maagdarmaanooeningen etc. kunnen lmaters metatal niet de subjectieve en objectief-subjectleve syndromen gerekeno morden, zoals Hogerzell doet. Het probleem van de vaststelling van de ernst van de andoening (en dus van de objectivite1t) is de eerste reden om Hogerze11's lndeling niet te hanteren. De tweede reden 1 dat een indejing naar functionele beperking in een onderzoek naar het arbeldsongeschlkt-z1Jn relevanter is dan een indeling ale primair gericht is op het arbeldsongeschlkt-worden. Ten derde levert de wel gebrulkte dichotomie een betere celvuliling dan een (aangepaste) indel1ng volgens Hogerzell zou doen.

3. De operationalisering van de te bestuderen facetten van het leven zonder werk wa niet envoudig. In de literatuur waren zeker aanknop1ngspunten aanwez1g voor concrete meet- 
methoden (schalen, testbatteriden etc.) doch het was meestal onmogelijk de daarin voorhanden veagen wolledig over te nemen. D1t wowel doordat de vraagsteling warop ze wren toegespltst niet overeenkwam met de onderhavige, ajs doordat de vragenlijst veel te lang en te moell1jk zou worden. Dit heeft ertoe geleld dat de in dit onderzoek gebrulkte enqueteformulieren $21 \mathrm{gn}$ samengesteld ult brokgtukken en gewljigde versies van bestaande testen, schalen en wagen en ult igen constructies. De vigenlijst is beproefd in een vooronderzoek en in proefinterviems voor het hoofalonderwek. 
HOOFDSTUK 4

DE BELEVING VAN HET LEVEN ZONDER WERK NA 4, 10 EN 16 MAANDEN ARBEIDSONGESCHIKT-ZIJN

In dit hoofdstuk is het transversale deel van het onderzoek aan de orde, gerleht op de wraggsteling sub 1 (pag. 41):

a. Hoe wordt het leven zonder werk door arbelasongeschikten beleefd na 4, 10 en 16 maanden;

b. waardoor wordt die beleving vooral belnvioed.

\subsection{De beleving op de verschiliende momenten}

De frequentieverdelingen van de acht belevingstems spreken duldelijke taal omtrent de mate warin men het leven zonder werk al dan niet vindt ult te houden.

De frequentleverdelingen voor de totale durgroeper $21 \mathrm{hm}$ In tabel 14 (pag. 78) weergegeven, gegroepeerd nar de twee dimensies die aan de acht ltems ten grondslag $11 \mathrm{ggen}$.

Wat betreft de eerste belevingsdimersis laat tatu: is duldelijk zlen dat een rulme tot zeer rume meerderinelc van de respondenten op leder moment de dagel1jkse gang van zaken in verschlilende opzlchten nlet erg waardeert: negen van de tlen willen liever vandaag nog aan het werk dan morgen en ariekwart van hen bewalt het allemal niet zo best.

Ter 11 lustratie van de overwegend onplezlerlge kartien van het arbelasongeschikt-zijn gelden de antworden op de open wagen "alo w nu alle dingen die u vervelend prettig vindt van de stituatie, warlin u zich bevindt, op een r 1 tje zet, wat zljn dat dar?"

zeer veel respondenten konden namelijk gén prettige alngen noemen: na 4 maanden was dat $40 \%$, na 10 en 16 
respectievelifk 38 en $31 \%$. Er waren daarentegen veel minder mensen die geen vervelende dingen konden noemen: respectieve11.k6, 5 an 6: van alle respondenter.

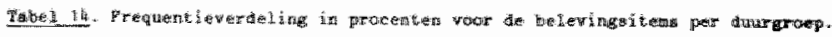

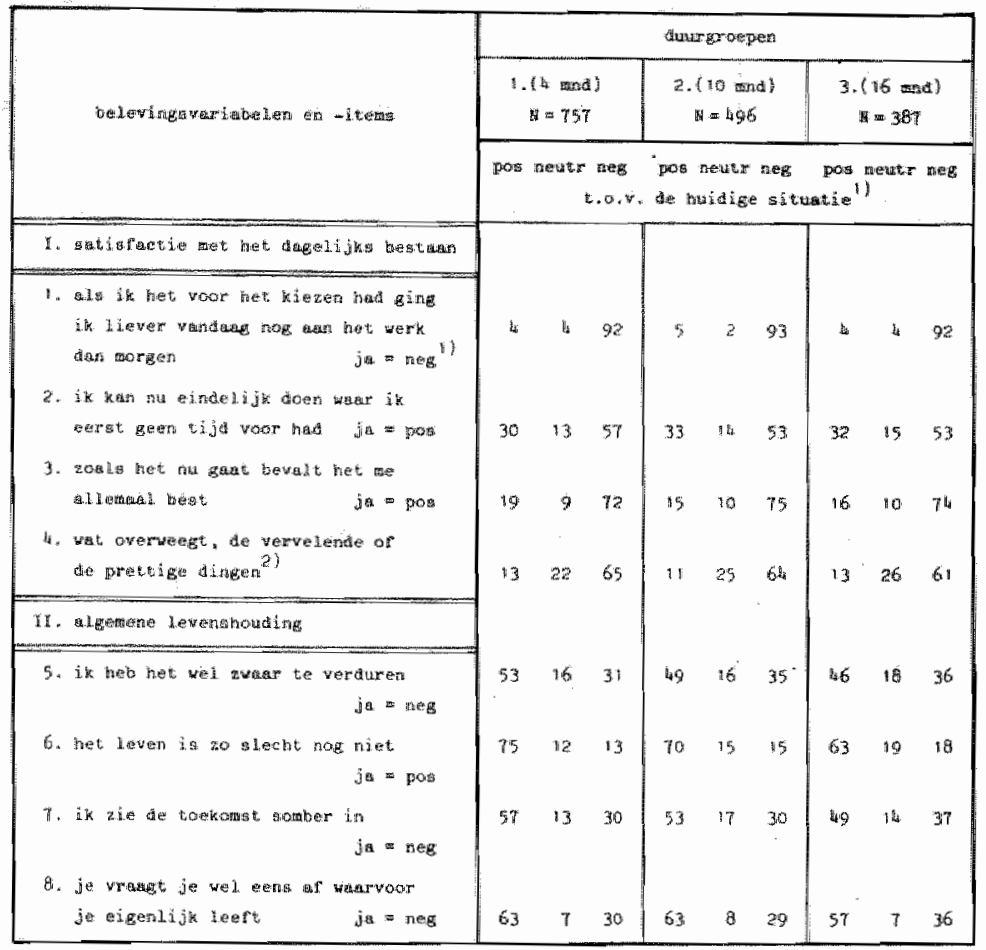

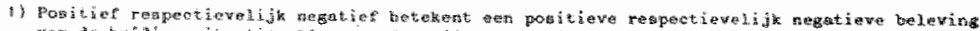

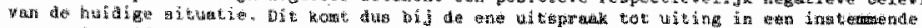

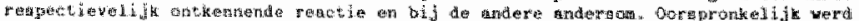

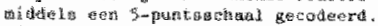

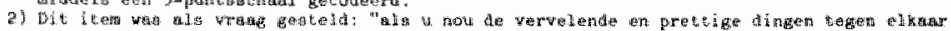

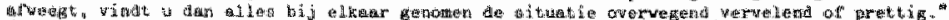

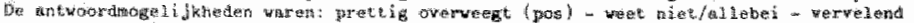

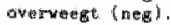

Het overwicht van negatlewe ervaringen blijkt ook ult het aantal mensen dat er mér dan één wist te noemen: rond $60 \%$. Slechts $22 \%$ van de geinterviewden noemden meer dan én prettig aspect van het arbeldsongeschikt-q $1 \mathrm{Jm}$. 
Over 1gens wist eerstgenoemd rytje percentages erop dat de ervaringen in de loop der maanden posltlever worden. D1t word ondersteund door de antwoorden op de vraag of men vindt dat de vervelende dan wel de prettlge dirigen overwegen: de vervelende dingen overwegen yoor 69 respectlevelijk 64 en $52 \%$ ( 4 resp. 10 en 16 maanden) en de prettige dingen voor respect1evelilk $12 \%, 10 \%$ en $16 \%$. aok in de longltudinale analyses - de veranderingen bij de groep driemal gelnterviewden - van de belevingsvariabelen komt dit positiever worden naar voren cpar. $5.1 \%$

In tabel 15 en 16 zin prettige en vervelende alngen wermela. De prettige alngen komen wooral neer op het gevoel van vrijheld, vrije tijd en een intenslever gezinsleven. Als vervelend werd in de eerste plates door de helft van de respondenten de aandoening genoemd, op afstand gevolgd door het niet-werken en vele andere zaken.

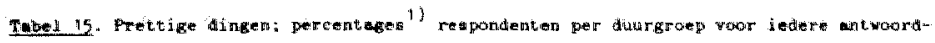

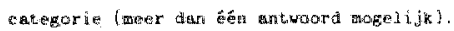

\begin{tabular}{|c|c|c|c|}
\hline \multirow{2}{*}{ pretetige dingerti } & \multicolumn{3}{|c|}{ Atustorromm. } \\
\hline & 1.84 mal & $2 .(10$ and $)$ & 3.116 ant: \\
\hline 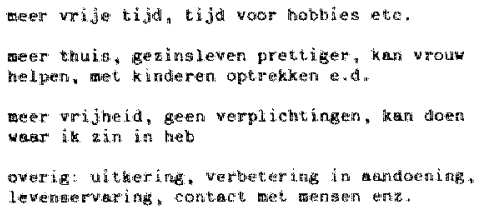 & 20 & $\begin{array}{l}30 \\
28 \\
13\end{array}$ & $\begin{array}{l}34 \\
26\end{array}$ \\
\hline$=$ & 754 & 496 & $3 \ddot{8} \%$ \\
\hline
\end{tabular}

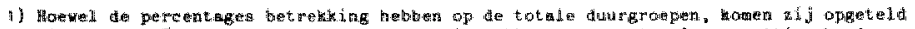

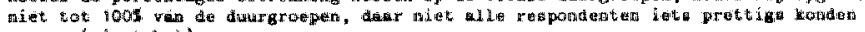

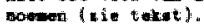




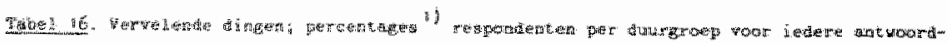

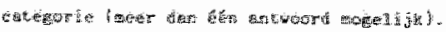

\begin{tabular}{|c|c|c|c|}
\hline \multirow{2}{*}{ 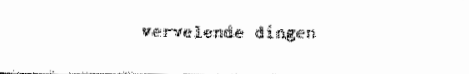 } & \multicolumn{3}{|c|}{ 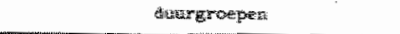 } \\
\hline & A.ti nind & $2.610-4,1$ & 3.176 mand \\
\hline 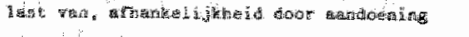 & 50 & 13 & 施 \\
\hline 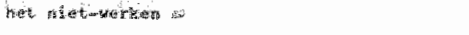 & 33 & 39 & 32 \\
\hline 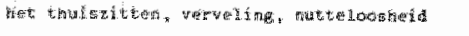 & 27 & alu & 18 \\
\hline 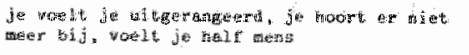 & 38 & 23 & 事 \\
\hline 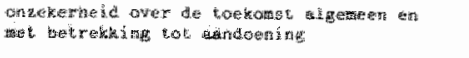 & 18 & it & 11 \\
\hline 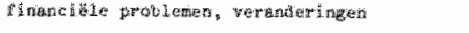 & 9 & 10 & $\mathrm{IT}$ \\
\hline 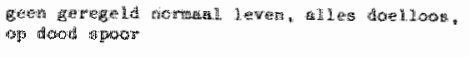 & 5 & Hal & 6 \\
\hline 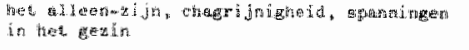 & 7 & 6 & $T$ \\
\hline 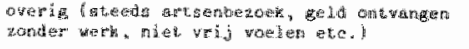 & in & $1 \%$ & $\nabla$ \\
\hline$y=$ & \%5\% & 496 & $3: 8$ \\
\hline
\end{tabular}

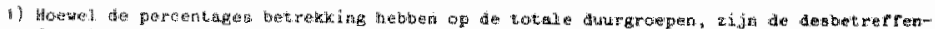

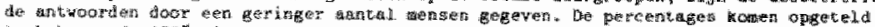

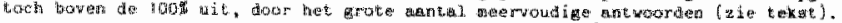

Howel voonzlohtigheld geboden is by het beoordelen van deze latute twee tabelien (het ziln spontaan gegeven artwoorien op apen vragen) teeft vooral tabel 16 aanlelding tot enkele opmenkingen.

De verveling blijkt in het begln meer mensem te trefien dan aan het eind, terwijl darentegen de langaur 15 arbeldsongeschikten veel vaker financiele problemen vermelden dar de kort arbeldsongeschtkten (zle ook par. 5. 1).

Keren we terug nar de twee belevingsvaryabelen, dan komt de overwegend negatieve atiafactie met het dagel1jkge leven zonder werk ook tot ulting 1 in de gezommeerde scores van de wler eerste belewingsitems, hoewel daran het grote antal negatieve soores minder opvallend 1 d dan het Geringe antal positieve scores. Slechtis 2-4 van de respondenten beantwoordt 3 of 4 ultspraken positief. 


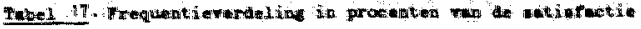

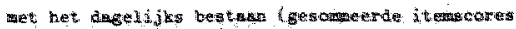

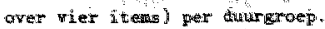

\begin{tabular}{|c|c|c|c|}
\hline \multirow[b]{2}{*}{ Shores } & \multicolumn{3}{|c|}{ arngrepepers } \\
\hline & 1. ( (4it and & $2 .(10$ and & $3 .(16)$ \\
\hline $4-7$ a meg & 55 & 53 & 49 \\
\hline $8-10$ & 3 & 35 & 35 \\
\hline $11-13$ & 12 & 9 & 14 \\
\hline $14-18=7 \times$ & 2 & 4 & 2 \\
\hline Toitent 1 & 100 & 701 & 100 \\
\hline 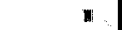 & 757 & 40 & 307 \\
\hline
\end{tabular}

De tweede belevingsdimensie geeft een duldelljk positiever beeld te alen: rond tweederde vam de respondenten geft met de ultspraak "het leven is zo slecht nog niet" blyroorbeeld aan dat er ondanks alles ook plezler1ge kanten aan het bestaan blifwen.

U1t de somscomes van deze dimensie bl1jkt echter dat men geen extreem positieve levenshouding heeft: de grootste groep respondenten is gematiga positief, Bevolgd door een groep gematigd negatieven. Anders dan bij de satisfactie 1s nu het antal negatleve ultspraken het meest In het oog springend: slechts $8 \%$ beantwoorit alle ultspraken negatief.

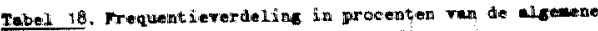

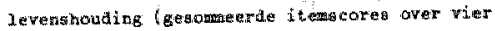

itews ) per alurigroep

\begin{tabular}{|c|c|c|c|}
\hline \multirow[b]{2}{*}{ Sicarat } & \multicolumn{3}{|c|}{ duntrestopen } \\
\hline & $\mathrm{A}_{\mathrm{a}}\left\{\begin{array}{l}4 \\
\text { and }\end{array}\right.$ & $z+(10 \mathrm{mid})$ & $3.4(16$ and $)$ \\
\hline $4-8=0 e 6$ & 7 & 8 & 8 \\
\hline $9-12$ & 26 & 26 & 3 \\
\hline $13=16$ & 64 & 31 & 42 \\
\hline $17=20=\mathrm{pan}$ & 23 & 15 & 17 \\
\hline Totent & 757 & 100 & $\begin{array}{l}\text { thoo } \\
388^{m}\end{array}$ \\
\hline
\end{tabular}


Het verschil tussen de twe belevingsvariabelen - de een overwegend negatief, de ander vel positiever - kan op verschlliende manieren cernterpreteerd worden.

Enerijds kan men veronderstellen dat de meeste arbeidsongeachikten een groot adaptatievermogen hebber: ondanks de dagelijkse ellende lat men zlch niet het ganse leven vergalien. Men neeme het leven zoals het $1 \mathrm{~s}$, houdt moed en bliyt de zorzidzien.

Anderzljds 1 wet ndet onwarschijniljk dat een negatieve algemene levershoudlng veel moliljker te ulten is dan een negatief oordeel over meer praktische zaken. Als men alles somber, zwaar en abelizos vindt geeft men min of meer toe het leven niet aan te kunnen. En dat doet men niet gauw, net zo min als wen er makkelijk toe komt on toe te geven dat men afgrijselljk werk heeft of een onutstaanbaar kind. Dergelifke uitspeaken aljn niet soclaal wenselijk, ze tasten het gevoel van elgenwarde aan on bovendien 16 er geen alternatief voor bet leven, het werk of het kind: men kan zlch er niet of nawelijks aan ontrekken. Zo beschouwd kunmen de positieve antwoorden op de algemene houding opgevat worden als ulting van een optimistische levensvisle, terwijl de negatleve antwoorden daarentegen ongetwifeld wi eer sombere levenswisle weersplegelen.

overlgens blijkt ult de vrly gerlinge samenhang tussen de somscores wan de satisfactie en de levenshouding $(r=$ $.23, .32$ en .32 voor de drie duurgroeper; $p \leq .05$ ) dat de levenshoud1ng behalve een positiever, ook duldelijk eer ander aspect wan de beleving van het arbeidsongeseh1kt-z1jn ls dan de satisfactie.

In de tabelien 14,17 en 18 valt op dat de ciffers van de vergchlilende duurgroepen sterk overeerkomen. Een conclusie omtrent de stablitelt var de beleving gedurence de onderzoeksperiode mag hierult echter niet getrokken worden. Hlerop zal in hoofdstuk 5 worden ingegan an de hand van de gegevens betreffende do drdemal geinterviewden. 
4.2. De achtergronden ran de satisfactie met het dagen IJks bestaan

De potentiele invloeden op de beleving van het leven zonder werk zijn samengebracht onder de noemers van de 24 onafhankel1jke baslsvarlabelen. Tenelnde darult de belangrifkste achtergronden van de beleving te kunmen ldentificeren $z i$ in multipele regressle-analyses ultgevoerd voor de twee belevingsdimensles op deze 24 onafharkelijke varlabelen. Deze analyses werden apart voor ledere subgroep blnnen ledere duurgroep ultgevoerd. In total derhalve $2 \times 5 \times 3=30$ analyses. 1 )

U1t deze analyses kwamen 15 varlabelen naar voren die bly minstens én belevingsamensie bij minstens twee subgroepen en/of duurgroepen een signiflcante partiele regresiecoëfflcient te zien gaven, hetgeen een redelijk criterlum leek on al te toevalilge effecten te kunnen identificeren en te elimineren.

op de 15 resterende onathankelifke varlabelen (zle par. 3.7 , de nummers $1,4,6,7,8,12,14,16 \mathrm{t} / \mathrm{m} 22 \mathrm{en}$ 24) werden opnieuw regressie-analyses ultgevoerd, zowel voor de subgroepen blinnen ledere duurgroep als voor de totale duurgroepen. B1J de duurgroepanalysos zIJn twee methoden geharteerd: "gewone" multipele regressie-ana:

ses en LISREL-analyses. Bij de eerste wordt gến, bij de tweede wèl rekening gehouden met de subgroepen. Het LISREL-programma ( 21 e b1jlage IIIc) construeert name11jk per duurgroep éen regresslevergelijk1ng op basls van de regresslewergel1Jklnger binnen de 5 subgroopen in die duurgroep. Vervoligens wordt getoetst of de vilf ubgroepen al dan niet significant van dit globale model afw1jken. Zo nlet, dan overheersen kennelijk de overeenkomsten tusen de subgroepen. Zo ya, dan ziln één of meer subgroepen duldell Jk verschillend van de arderen.

Deze twee duurgroepanalyses leverden vriJwel Identieke resultaten op, dat w11 zeggen dat de regresslestructuren van de totale duurgroepen in sterke mate overeenkwamen 
met de gemeenschappelijke regressiestructuren van de subgroeper per aungroep.

Tenelinde de resultaten zo overzlehteligk mogeligk te kunnen prewenteren 1 allereerst besloten in dit hoofasuk de abroepen nlet apart te behandelen. De desbetreffende gegevens $21 \mathrm{Jn}$ als bljlage IIIa opgenomen. Bovendien 1 besloten om het cljfermateriad te beperken tot de gewone regressie-analyses voor de drie durgroepen (tabellen 19 en 20 ). In de tekst.worden de achtergronden var de 4, 10 en 16 mandsgroepen beschreren, voor zover die ult gewone en de LISREL-analyses lidentiek naar voren komen. Eventuele verschilien tussen de ultkomsten van belde analyses worden zonodle apart vermelid, evenals de blyzonderheden wan de subgroep die afwijkende resultaten te zlem geert (de oudere handarbelders met beweglagsmoe111, Jkheder; z1e par. 4.5).

In de tabelien 19 (pag. 85) en 20 (pag. 90) z11n voor de twee belevingsdmensies zowel de $0^{\mathrm{e}}$-orde correlatiecoefflcienten als de Gestandaardiseerde partiele regresslecoefflolenten vermeld met de 15 onafhankel1 jke varlabelen, leeftidd, beroep en abuoening (voor zover signiflcant bij a $\leq .05$, tweez1jdig getoetst, $r \geq .07, .09$ resp. .10), alsmede de multipele correlatlecoéfficien$\operatorname{ten} 2)$

op leder moment in het arbeldsongeschlkt-ziln wordt een significant deel van de varlantie in de satisfactie met het dagelijks bestaan door de gezamenlijke onafhankel1 Jhe variabelen verkiaard: 34,35 en $35 \%$ (p <.001). Opvallend 1 a det voljwel alle onafhankelljke varlabelen daaraan bljargen; alleen de buurt, de utthulatgeld en de leeftijd hebben geen rechtstreekse invloed op de satsitacte. 3 )

Eveneens opvaliend is dat de werkwardering bid ledere durigroep bovenaan stat, gevolgd door de evaluatle van de to jabesteding. 


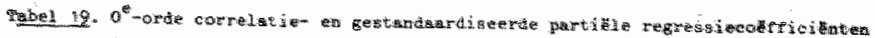

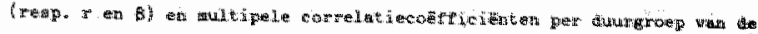

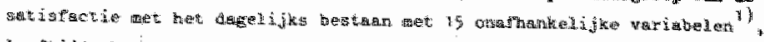

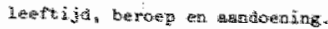

\begin{tabular}{|c|c|c|c|c|c|c|}
\hline \multirow{2}{*}{ 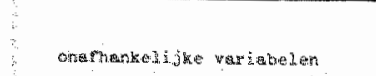 } & \multicolumn{6}{|c|}{ dwh grśnen } \\
\hline & \multicolumn{2}{|c|}{ 1. (h) and } & \multicolumn{2}{|c|}{ 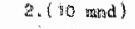 } & \multicolumn{2}{|c|}{$3 .(6,6$ and $)$} \\
\hline . & $r$ & 药 & 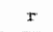 & B & $\overline{\mathrm{n}}$ & $\mathrm{b}$ \\
\hline 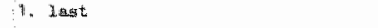 & -24 & -.71 & -.97 & & -.93 & \\
\hline 4. ge 3onther idsoondere? & .22 & .00 & .12 & & .19 & \\
\hline 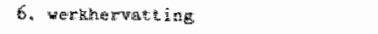 & .12 & & -.10 & $m .16$ & & \\
\hline 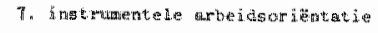 & .22 & .10 & +17 & .04 & .24 & . 1: it: \\
\hline 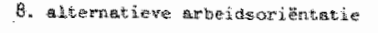 & .21 & .13 & $\therefore 2$ & .14 & .26 & .2 \\
\hline 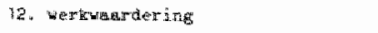 & -.37 & $=.28$ & -.31 & -.24 & -.35 & 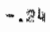 \\
\hline 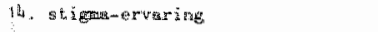 & -.09 & -.56 & & & & \\
\hline 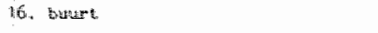 & & & & & & \\
\hline 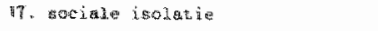 & -2 . & -.10 & -27 & -214 & -.28 & $-\times 10$ \\
\hline 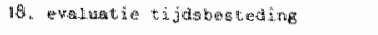 & 30 & .20 & $.3 z$ & .23 & .35 & .19 \\
\hline 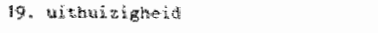 & .10 & & & & .75 & \\
\hline 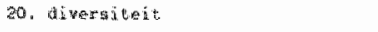 & $.2 i$ & .10 & $.2 \mathrm{H}$ & .10 & .26 & \\
\hline 21. simen in thet gezin & & $-\infty, 09$ & & -.09 & & \\
\hline 22. riactide troun & .20 & .09 & .2最 & .1 & .27 & .13 \\
\hline 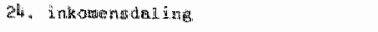 & & & -.12 & $-{ }_{n} 0 \theta$ & & \\
\hline 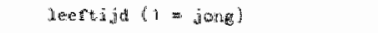 & o. . I1 & & & & & \\
\hline 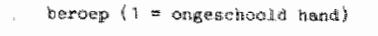 & & $-.0 \gamma$ & & -.69 & & \\
\hline andominge & & & & & 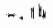 & -.69 \\
\hline madt tipele $r$ & & .158 & & .59 & & .55 \\
\hline
\end{tabular}

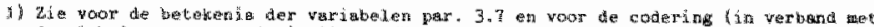

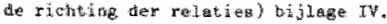

Het belang van de overige variabelen wiselt per duurgroep, maar ook darin 1 s wel enlge systematlek te ontdekker. Daartoe is allereerst een overzicht gemakt van het aantal malen dat ledere onafhankelijke variabele een signifloante regressiecoefficlent $4 \mathrm{p} \leq .05$, maximaal

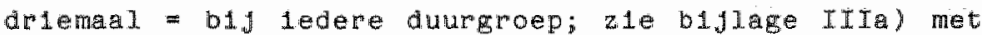
de satisfactle opleverde.

Daanut blijken 6 varlabelen op leder moment van belang voor de satisfactie, en 3 op twee momenten. Wanneer de

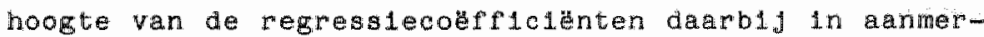
king worat genomen leldt dit tot een rangowde un de achtergronden van de satisfacte met het dagellyks bestaan, zoals die in sohema $z$ (pag. 86) in de kolom total is vermeld. 


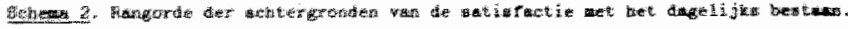
Vartitite

\begin{tabular}{|c|c|c|c|c|}
\hline \multirow{2}{*}{ 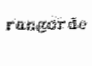 } & \multicolumn{3}{|c|}{ 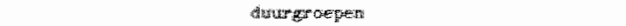 } & \multirow{2}{*}{ thet $\bar{t}=\mathrm{a}$} \\
\hline & 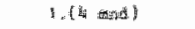 & $2 .(10$ and $)$ & 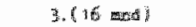 & \\
\hline 1 & 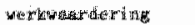 & 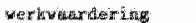 & 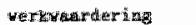 & 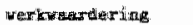 \\
\hline 2 & 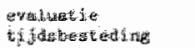 & 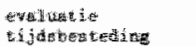 & 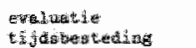 & 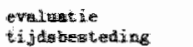 \\
\hline 3 & 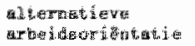 & Hetkersets & 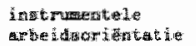 & 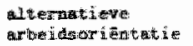 \\
\hline b & 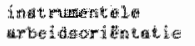 & 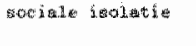 & 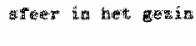 & 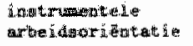 \\
\hline 5 & 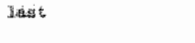 & 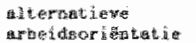 & 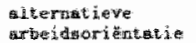 & resute trow \\
\hline 6 & 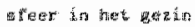 & 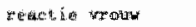 & 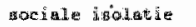 & gotale isolatio \\
\hline i & Boctale istatio & ditwerget & Aantidow $i$ the & gfeer in bet gen \\
\hline$\dot{B}$ & 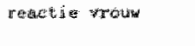 & Berate & & 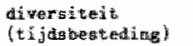 \\
\hline 9 & 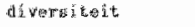 & areot in het getrin & & \\
\hline 10 & 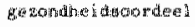 & inkomengat a & & \\
\hline 11 & botrop & 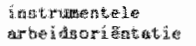 & & \\
\hline 12 & estiggon & & & \\
\hline
\end{tabular}

Duldel1jk 1s, dat de ldeeên over het vroegere werk en werken in het algemeen de belangrijkte zijn bij de beoordeling van de huldige levensomstandigheden. Dit komt voomal door de invloed van de werkwarrdering. De satisfactle met het dagel1Jks bestaan rangt op leder moment dus wooral af van de grote mate warin men het vroegere werk mist, plewier in het vroegere werk had en werken belangryjk vindt (de maxlmale werkwaardering is 6 ; de gemiddelde 5.5). Met name het werkgemls blijkt an de gerlnge satisfactie debet. ${ }^{4}$ ) De meest genoemde redenen warar men het werk miste, maren de contacten en de sfeer op het werk, de regelmat, het doel in het leven alsmede het niets doen, de verveling en de nutteloosheld nu (z1e tweede NIPG-wersiag, warult ook verder in deze paraceraf $1 \mathrm{~s}$ geput).

Het bovenstande wist erop dat de satisacte voora l belnvioed wordt door a vergeligklng met de vroegere levensomstandigheden waarin, zeker voor deze vergelijking, werken het belangrijkste element was. 
Nast de berinnering aan het concrete elgen werk speelt ook de arbeidsorientatie en duldelljke rol bil de satisfactie met het arbeidsongeschikt-zijn na 4,10 en 16 maanden. Hoe meer men werken zlet als een noodzakelijk Whad en als een manier om geld te verdienen ce instrumentele arbeldsomiëntatie) en hoe sterker men de mening is toegedaan dat er meer mogelijke bezlgheden alln dan werken aljeen en dat ledereen daartussen zou moten kunnen kiezen (de altermatieve arbeldsoridntatle) des te plezieriger vindt men het lewen zonder werk. De Instrumentele visle op arbeld wordt ongeveer even vark wel als nlet gehuldigd; de alternatieve vaker niet dan wel.

De tljasbesteding vormt de tweede achtergrand van de satisfactie. Duldel1,k bI1fkt, dat het aordeel over de tijasbesteding (de mate warin men wich verveelt, de bezigheden boelend, plezierlg, wardeval e.d. vindt) belangrifker 1 s dan de concrete bezlgheden. Het doet er kennellyk minder toe wat ye precles doet en hoeveel, als Je je mar nlet verveelt, doch het gevoel hebt at de bezlg bent, en vooral plezlerig en zlnvol bezig bent. Hoewel slechts $10 \%$ van de respondenten zloh noolt verveelt is de evaluatie van de tijdsbesteding tooh vaker positief dan negatief".

Het gezin vormt globaal bezlen de derde achtergrond voor de satisfactle met het dagelifks leven. op leder moment draagt een positieve reactie van de vrouw cruim eenaerde wan hen windt het wel plezierig dat har man thuis is) bij tot ziJn positief oordeel over het dage$11 \mathrm{jks}$ leven. Daarentegen dragt een goede sfer in het gezth (die vaker als ontspannen, vrolljk, gerellide.d. word arigeduld dan als het tegendeel) b1j tot een negatleve satisfacte tijens de tulektewetperlode (4 en 10 manden). Deze onverwachte dnvloed van de gezlnosfeer 1 is vooralsnog onverklaarbaar.

De Boclale 1salatie ${ }^{5}$ heeft ongeveer evenvel invloed op de satisfacte (hoe sterken men het gevoej heeft averal bulten te staan als je nut werkt, hoe negatiever 
de atisfacte) als het gezin. Wellswar 1 s de invloed van de 1solatiegevelens bil 4 en 10 maanden groter dan die van de Individuele gezinsvarlabelen, zo blifkt ult de LISREL-analyb, dow het versch1l is niet groot en b1. 10 maander is het gezin, dat w1 zeggen de react1e van de wrow julist belangrijker. Rond de helft der respondenten heeft bet gevol nu overal bulten te staan.

De ernst van de zlekte 1 s alleen in het begin van de arbe1osongesch1kthe1d rechtstreeks van belang voor de satisfactie. Hoe meer last men van de kwaj. heeft en hoe meer men zlohzelc als zieke of gehandlcapte zlet, des te onplezlerlger vindt men de huldige levensomstandigheden na 4 manden. Daarna heeft de ernst van de ziekte niet meer rechtstreeks, mar y1a de tijdsbesteding invioed op de satisactie: een ernstiger zlekte men heeft lets wher veel dan weinfg last en vindt zichzelf waker ziek/ gehandlcapt dan gezond draagt biy tot een welnig gevarleerde en (mede daardoor) nutteloos en onplezierls bevonden tigdsbesteding alsmede tot verveling, betgeen we lechtstreeks de satisfactie beperkt.

De werkhervatt1ngsprognose belnvioedt de satisfactie aljeen na 10 maanden arbeldsongeschikt-zijn. Het is dan de derde achergrond van de satisfacte na de werkwardering en de avaluatle van de tijdsbesteding. De richting van de relatle wekt verwonderlng: als men de kans op werkhervating wel aanwezig acht (27\%) is de sat1sfactle lager dan wanneer men die kans nlet aanwezlg acht (34\%; $39 \%$ heeft geen ldee over ziln kansen). Deze relat1. biljkt veroorzaak te worden door het ltem "zoals het nu gat bevalt het me allemal best"; een ultspraak die dus door mensen die niet denken te hervatten waker onderschreven wardt.

Wat de achtergronden hlervan $z 1 \mathrm{In}$ 1s duster; evenzo 18 net onverklarbac warom deze relatie alléén ma 10 manden arbeldsongeschikt-zign bestat.

De omgeving is als achtergrond roor de satisfactle te verwarlozen. De buurt (gezelilg, vertrouwd of niet) 
oefent helemal geen invioed op de wardering utt de stigma-ervaring slechts een beetje na 4 maanden: als men het gevoel heeft dat men anders bejegend wordt (meestal op grond van het nlet-werken, een proflteur wordt gevonden of in staat geacht tot werken (en dat gevoel kent ongeveer de helit der respondenten), dan ervaat men het dagelijks bestaan als lets onprettiger.

Hoewel niet ledere onathankelijke variabele op leder moment de satisfactie met het dagelijks bestarn beinvloedt, kan toch geconcludeerd worden dat de satisfactle door een tamelijk stabiel patroon van achtergronden wordt gekenmerkt. De meeste facetten van het lieven zom der werk zijn immers wèl op leder moment van belang voor de satisfactie.

Alleen de (ernst) van de zlekte past duldelijk nlet in dit stablele patroon: zij beperkt de satisfactie uitslutend na 4 maanden arbeidsongeschikt-zijn.

ook de invloed van de basiskemerken leeftijd, beroep en aradoenting op de satisfactie, owerigens ninll of zwak, is niet op leder moment dezelfde. Handarbeiders in de Zlektewet $z 1 j n$ over het algemeen lets tevredener dar hoofdarbelders, althans wanmeer men belde vergelijkt bly identleke geschatte werkhervattingskansen. Doet men dat niet dan wordt dit beroepsefiect overschaduwd door het effect van de werkhervattingsprognose hetgeen overigens voor de handarbelders door hun slechtere prognose bók een positiever satisfactie inhoudt.

Na 16 manden arbeldsongeschiktheld zijn degenen met en

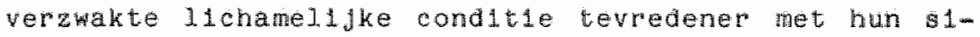
tuatle dan degenen met bewegtrigbeperkingen.

overlgens $1 \mathrm{~s}$ een verklaring van het werschl tiusen hoofd- en handarbelderis en tussen cond1tle- er bewesingsbeperkingen mol11Jk te vinden, wanneer deze zoald blijkt uit de regressie-analyses niet gezocht mag woraen In bijvoorbeeld de ernst, van de zlekte, het werkemis on de hervattingskansen. 


\subsection{De achterconden van de algemene levenshouding}

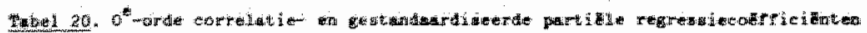

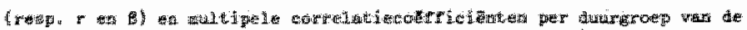

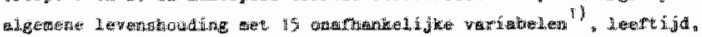

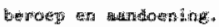

\begin{tabular}{|c|c|c|c|c|c|c|}
\hline \multirow[b]{2}{*}{ 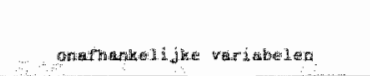 } & \multicolumn{6}{|c|}{ dindergroefoten } \\
\hline & \multicolumn{2}{|c|}{$1 .(4$ atrid $)$} & \multicolumn{2}{|c|}{$2 \ldots,\{10$ and $\}$} & \multicolumn{2}{|c|}{3.16 and } \\
\hline & Е & Q: & $\mathbf{r}$ & $B$ & 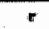 & 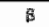 \\
\hline 1. 2 ast & -.30 & -.09 & -.28 & $\sim .98$ & -.13 & \\
\hline 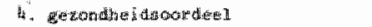 & .35 & .12 & ـ & $. \mathrm{H}\}$ & .26 & .13 \\
\hline 6. Hexkherwhte ing & $.38 \mathrm{i}$ & .21 & .18 & & 4113 & \\
\hline 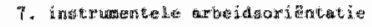 & & & & $\approx 40$ & & \\
\hline 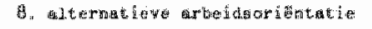 & & & & & & \\
\hline 12. werkwaurater rag & & & & & & \\
\hline 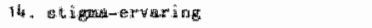 & 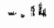 & & $-.2^{l i}$ & -.15 & & \\
\hline 76. butrt: & & & & & & \\
\hline 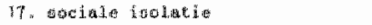 &,- 32 & -.18 & -39 & -.20 & -.40 & -.25 \\
\hline 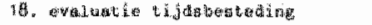 & .36 & .78 & .39 & .22 & 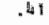 & .22 \\
\hline 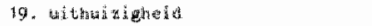 & .42 & & .16 & & .13 & \\
\hline $20 x$ divertitent & a筷 & & .23 & & $2 \mathrm{Ah}_{\mathrm{k}}$ & \\
\hline 21. of foter to thet gentin & .25 & .15 & .23 & .11 & .20 & \\
\hline 22, renterie virour & .22 & & $-2 e^{2}$ & & .26 & .10 \\
\hline 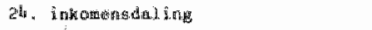 & -.37 & -.09 & -.16 & -.12 &.,- 19 & -.11 \\
\hline Heeftigu $(1=$ jong $)$ & $-x=$ & -.09 &.- .13 & -.74 & & \\
\hline 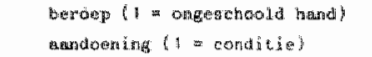 & .17 & & & & .13 & \\
\hline tan theter $r$ & & .60 & & .60 & & $.5 T$ \\
\hline
\end{tabular}

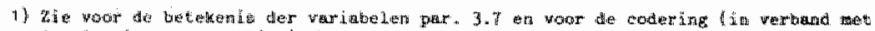

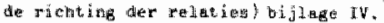

B1 een eerste inspectie van tabel 20 valt op dat de werkwarderling geen enkele en de arbeldsorientatie slechts zeer incldentele en geringe Invlaed op de levenshouding hebben. Een groter tegenstelling met de achtergronden van de satisfactie 1 s nawwelijks denkbaar. Alle variabelen bil elkaar verklaren $30 \%, 36 \%$ en $32 \%$ $(p$ ( $00 \mathrm{~d})$ van de levenshouding op de verschiliende momenten. Globaj. beslen dragen dartoe de soclale 1solitie en de eveluatie van de tijdsbesteding het meeste bif; ziJ woter echter bij 4 mazanden overtroefd door de werkbervat ingsprognose. 
Alvorens deze 1nvloeden nader te bespreken word allereerst de globale rangorde der achtergronden van de algememe levenshouding gegeven, welke evenals bij die vam de satisfactie 1 opgesteld op basis van de hoogte der regresslecofflclenten en het aantal malen dat ledere onafhankel1jke varlabele en significante megresiecoefflcient oplevert (bljlage Irid). De eerste vier variabelen in de kolom total in schema $3 \mathrm{z}$ inn op leder moment var belang: ae daaropvolgende drie variabelen op twee momenten.

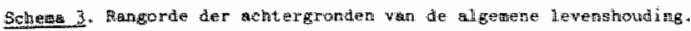

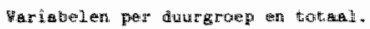

\begin{tabular}{|c|c|c|c|c|}
\hline \multirow{2}{*}{ ramigorde } & & 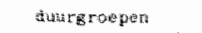 & & \multirow{2}{*}{ 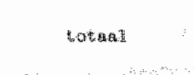 } \\
\hline & $1 . \quad 14$ and & $2,(10 \mathrm{mra})$ & $3 .(76$ sast $)$ & \\
\hline 1 & 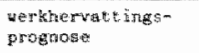 & 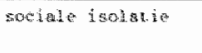 & Sotiole isolotion & 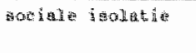 \\
\hline 2 & soriale isoliatis & $\begin{array}{l}\text { avaliatid } \\
\text { Hi, jubesteding }\end{array}$ & 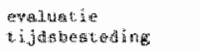 & 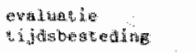 \\
\hline 3 & 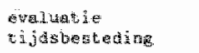 & sti gra & 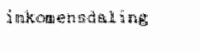 & 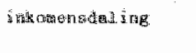 \\
\hline 3 & sther in het gendial & 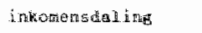 & 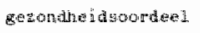 & 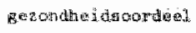 \\
\hline 5 & Gezondhe idsoordeol & berentida & 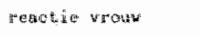 & gfaer ith het gerin \\
\hline 6 & infonengdad ing & wefer in bees gersin & & Inet van the thekte \\
\hline 7 & Lasit & secondhe & & 20ertis \\
\hline 8 & 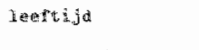 & Los: & & 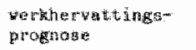 \\
\hline
\end{tabular}

De algemene levenshouding wordt over het algemeen vooral door het gevoel overal bulten te staan bepaald: hoe meer men wlch geisoleerd voelt, noe somberder de levenshoud 1 ing.

In de tweede plaats araagt verveling, het gevoel nlets gedaan te hebber en een als onplezserig, nutteloos en wardeloos ervarer tijasbesteding bld tot con sombere k1jk op het lewen. Meer nog dan bij de satisfactie is bij de levenshouding de ervaring der tijabesteding belangrlyker dan de concrete bezigheder.

De soclale isolatie en de evaluatie van de tijdsbesteding $z 1 j n$ na 10 en 16 matnden arbeldsongesch1kt-zijn 
duldel1Jk de belangrifkste achtergronden wan de levenshouding. Na 4 maanden $21 j n$ zIJ ook van groot belang, maar de belangrljkste bljarage tot de levenshouding wordt op dat moment door de werknervatingsprognose geleverd: hoe weet kansen men ziehzelf op werkhervatting geeft, woe optimistischer men het lewen (in tegenstel1.ng tot het dagelijks bestaan) ziet, althans in het begin; later doet de werkverwachting er woor de levenshoudling niets meer toe.

De eerste manor na het ophouden met werken wordt het arbeldsongeschikt-z1.jn over het algemeen (mog) niet als een defindteve zaak gezlen. af men heeft een vrli reele kans op werkhervatt1ng (dat geldt vooral voor de Jongeren met een verzwakte algemene conditle, dus voor subgroep 1) of men hoopt nog, tegen beter weten in, weer an de slag te komen. In belde gevalien is de toekomst rooskleuriger en het heden als intermezo meer aanvarabaar naamate men de kansen op werkhervattung hoger schat.

Na verloop wan t1jd wordt het voor velen echter onmoge$11 \mathrm{kk}$ om het arbeldsongeschikt-ziln als tijdelijk te blifven zlen en ook al doet men dat nog wel dan hebben de facetten van het arbelcsongeschikt-zijn toch zo"n stempel op het leven gedrukt dat het heden meer bepalend voor de levenshouding is dan de toekomstverwachtimg.

Het gezin vormt de derde achtergrond woor de levenshouding. De lnkomensdaling doet zlch op leder moment gelden: naarmate de gevolgen daarvan merkbaarder $21 \mathrm{fn}$, wordt het leven zwarder bevonden. De sfeer in het geain neeft, in tegenstelling tot de invloed op de satisfactle, een posdtief effect op de levenshouding: een ontspannen, gezellig, wrolljk gezln makt het leven araag$11 \mathrm{ker}$.

Die (ernst van de) zlekte heeft alle momenten lnvloed op de levenshouding. Vooral de menlng over de mate van gezondheld 1 s van belang: hoe gezonder men zich voelt, hoe blljer men in het leven stat. 
De omgeving is evenals voor de satisfactle voor de levemshouding te verwarlozen. Wellswaar draagt na 10 maanden het gevoel dat men anders bejegend. wordt, voor proflteur wordt aangezien en beschouwd wordt als lemand. die best zou kunnen werken, blj tot een sombere levenshouding, doch b1j 4 en 16 maanden 1 s daarvan niets merkbaar. Bovendien staat de levenshouding geheel las var de karakterisering van de buurt.

De visle op net werk(en) 1s, zoals in het begin van dece paragraar al is opgemerkt, een eveneens te verwarlozen lnvloed op de algemene levenshouding.

Al met al kan worden vastgesteld dat ook de levenshouding een vryy stablel patroon van achtergronden kent gedurende de bestudeerde perlode. Wellswar oefent niet ledere individuele varlabele op leder moment invloed op de levenshouding ult, mar de verschlliende facetten van het leven zonder werk $z 1 \mathrm{Jn}$ wel op leder moment ongeveer even belangridk. Alleen de werkhervattingsprognose verstoort dit algemene beeld: $z 1 j$ is alleen na 4 maanden arbelasoneschikt-zijn van (groot) belang voor de levenswiste.

De 1nvloed van de bas1skenmerken leeft1jd, beroep en aandoening is evenmin bif alle duurgroepen hetiolfde. Tifdens de zlektewetperiode bligken jorower inlindk somber gestemd dan de ouderen. Het breekpunt tussen belde ligt rond de 35 jaar. Het is nlet onwarschljnlljk dat hier het verschijnsel dat in paragraaf 4.1 werd genoema als oorzaak voor de vrij positieve levensvisle een rol speelt: zo het al moeliljk is om toe te geven dat men het leven elgenl1jk nlet meer ziet zitten, geldt dat a fortior 1 woor de jongsten, dle 1mmers nog en heel. lever voor zloh hebben. Bovendien kan men veronderstellen dat jongeren over het algemeen een grotere flexib111telt hebben on zich min of meer aan te passen ande nleuwe omatandigheden, hoewel dit lets minder waarschijnligk 1s.

Is men eenmal in de WAO beland, dan geldt dit leef- 
tijaverabil niet meer.

Het felt dat hoofdarbelders over het algemeen minder somber 24 jn dan handarbelder $10^{\mathrm{e}}$-orde correlaties tabel 20) blifkt verklaard te worden door hun grotere werkhervatt1ngskans (b1. 4 matanden) en hun geringer gevoel van Boclale liolatie (bid 16 maanden).

De ard van de andoening makt voor de lewenshouding geen versch11.

\section{4. Qverechkomsten en versch1lien tussen de twee belev1ngs- dimens 1es}

De achtergronden van de satisfactie met het dageligks bestaan en de algemene levenihouding weersplegelen de 1nhoudel1jke overeenkomsten en versch1llen tussen deze twee aspecten van de belev1ng van het leven zonder werk. De overeenkomst tussen de dimensles, de beleving van het leven-zonder-werk-alles-b1j-elkaar-genomen, komt naar voren in het feit dat de meeste facetten van het leven zonder werk in dezelfde volgorde de dimensles beInvloeden. De verschilien tussen de satisfactie on de levenshouding, dle groter $z 1 j n$ dan de overeenkomsten, komen tot ultdrukking in het verschil in de belangrijkgte achtergrondfacetten en vooral in de ind1viduele varlabelen die blj de ene dan wel de andere dimensle en rol spelen (schema 4 , pag. 95).

Het meest opvallende versch1l tussen de belevingsdimensles 1 g de mate warin ze door de ldeeen over het vroegre werk en merken in het algemeen belnvloed worderi.

De herınnerıng aan het werk - het werkgemis, de tevredenheld met het werk en het belang wan werken - 1s op leder moment de belangrigkste matstaf om het huldige dage 1 jks leven as af te meten terwll de levenshouding er in het geheel niet door geraakt wordt (er niet eens een signifioante of-orde correlatie mee vertoont). 


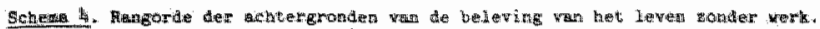

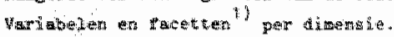

\begin{tabular}{|c|c|c|c|c|}
\hline \multirow[t]{2}{*}{ ramgarde } & \multicolumn{2}{|c|}{ Yari gledem } & \multicolumn{2}{|c|}{ tarcalteds } \\
\hline & :ataffactid & Lewenshowaing & satisfactie & Leversithonatiog \\
\hline 1 & Wertcwardering & 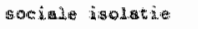 & viso op werkenten & 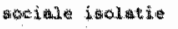 \\
\hline a & 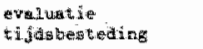 & 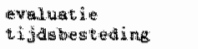 & tijosbegteditis & 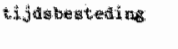 \\
\hline 3 & $\begin{array}{l}\text { alterabtiewe } \\
\text { arbeidsorifntatie }\end{array}$ & i.nikcanensidating. & gevesin & wein \\
\hline 4 & 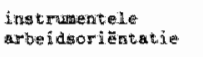 & Gezondhe idsworded. & accialle isolutie & $\begin{array}{l}\text { ertast van the } \\
\text { 2ieke }\end{array}$ \\
\hline 5 & resingie troury & steer in het gegin & $\begin{array}{l}\text { erngt: van de } \\
\text { wakite }\end{array}$ & 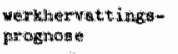 \\
\hline 6 & wociale inolotie & 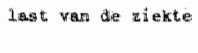 & $\begin{array}{l}\text { verkhervet ingsi- } \\
\text { prosnose }\end{array}$ & omgeviting \\
\hline 7 & sfeer in heo geain & leertijia & amgeving & witite of werk (en) \\
\hline 8 & $\begin{array}{l}\text { diverefteit } \\
\text { tijulabesteding }\end{array}$ & $\begin{array}{l}\text { wabnerwatt ings- } \\
\text { pronose }\end{array}$ & & \\
\hline
\end{tabular}

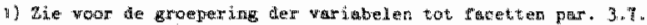

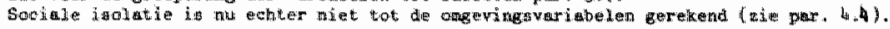

Dok de visle op werken in het algemeen - werken is een noodzakel1jk kwaad, een manier om geld te verdlenen, én van vele mogelifke bezlgheden die je naar keuze zou moeten kunnen verrichten - heeft op de satisfactle een duldel1jko, doch op de levenshouding een te verwarlozen Invloed.

Aangezien drie van de vier ltems van de satidictie zifn gesteld in termen wan een directe vergel 1 hing van het heden met het verleden (11ever vandals cam het wel dan morgen, zoals het nu gat bevalt het allemal best, 1k kan nu doen waar 1 k eerst geen t1jd voor had) hoeft het nlet te verbazen dat het belangrijkste element van het verleden - werken en het elgen werk - de ultkomst van deze afweglng het sterkst bepalt. opvallend 1 wèl, dat dèze terugblik naar het verleden bld de levenshouding geen enkele rol speelt. Want hoewel de tweede belevingsdlmens le qua formulering u1tslultend het huldige en het toekomstige bestaan betreft - leven $1 \mathrm{~s}$ zo slecht (nog niet), zwar te verduren, toekams somber, je wraagt je af warwoor je leeft - spreekt bet vanzelf dat deze ultspraken niet los van vroegere ervarlngen worden gedaan. 
Dit wordt onderstreept door de termen warin de belangrikste teden voop de sombere levensvisle - de soclale 1 aolatie - ls verwoord: als je niet werkt, sta je overal buten.

Het verschll tusien de satisfactie en de levenshouding 1 s dan ook niet gelegen in de relatie tussen met heden en het verleden; dat de huldige situatie beleefd wordt in het licht van de vroegere omstandigheden geldt woor belde dimensids.

Het verschil $z 1$ them in het accent dat op het verleden respectleveldjk het heden (en de toekomst) wordt gelego. Bly de satisfactie van het dagelifks bestaan valt de nadruk op het gemis en de betekenls van het vroegere werk en werken in het algemeen, voor zover die in de gewone dagel1jks gang wan zaken voelbaar z1jm.

Bly de algemene levenshouding $11 \mathrm{gt}$ het accent op de meer gevoelsmat1ge ervaringen van het arbeldsongeschikt-zijn als op zichzelf staande levensfase, welke nlet zozeer Jelden tot specifleke warde-oordelen over die levensfase als wel tot een meer algemene beschouwende kljk op het leven.

Dit accentversch1l is ook te herkennen in de belangr 1 jkste andere verschllien tussen de achtergronden van de twee belevingsdimensies.

De ervaren ernst van de zlekte - met name de mate warin men zlch ziek/gehandicapt dar wel gezond voelt is voor de levenshouding veel belangrijker dan voor de satisfactie. Dit zou kunnen betekenen dat de zlekte niet zozeer van belang 1 als een in praktische zin hinderlijk fyslek gegeven doch vooral als de basls voor een welfbeeld: zleke/gehandicapte, warmee het leven nu en In de toekomst somber wordt gekleurd.

De Invloed van de gezinsomstandigheden op de satisfactle geschledt vooral via de gezinsvarlabele met de duldelifkste relatie met het verleden: de mate warin de 
man denkt dat $21 \mathrm{jn}$ vrouw het prettig wind dat his zoveel meer thuls is en de toe- of arname ran onderlunge spanningen, die hij constateert. Deze varlabele hangt naumell Jks samen met de levenshouding. Daarentegen is de inkomensdaling roor de levenshouding belangrijker dan voor de satisfactie. De verklaring daavan is melilcht dat nlet alleen de aanpassing van de ultgaven an de

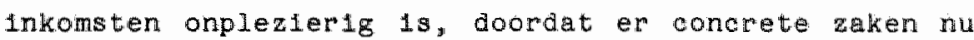
niet meer gekocht of gedaan kumnen worden die men vroeger wel kocht of deed, mar dat vooral het blifwend woorultwcht van het moeten afwegen van de mogelijkheden en onmogelifkheden, van het moelzaan de elndjes aan elkaar knopen, tot somberheld stemt.

Een derde versch1l tussen de belevingsamensies betreffende de gezmsinvloed bligt echter onverklaambaar. De sfeer in het gezin - gezellig, ontspannen, vrolidk etc. - heeft na 4 en 10 manden een positleve 1nvloed op de levenshouding mar een, $21 j$ het lets zwakere, negatieve op de satisfactle: naarmate de sfeer beter 1s, wlet men het leven zonder werk minder somber, maar verkiest men toch meer het leven met werk. Dit laatste geldt met name de hoofdarbelders, mar dat brengt de verklaring niet dianterb11.

De werkhervattingsprognose, die de huldige omstandi. den 1 het $11 \mathrm{cht}$ van de toekomstige stelt, $1 \mathrm{~s}$ daardoor elgenl1 Jk vanzelfsprekend voor de algemene levenshouding belangrijker dan voor de satisfactie. Dat de prognose op de laatste toch effect kan hebben, wordt waarschijnlijk veroorzakk door het felt dat de verwachte en gewenste toekomst Identiek $1 \mathrm{~s}$ a an het gemiste en teruggewenste verleden. onduldelljk enter bl1jft warom de werkhervat ingskans op de satisfacte en negatief effect heeft.

De twee facetten van het leven zonder werk laten nast verschlllen ook overeenkomsten tussen de achtergronden van de satisfactie en de levenshouding zien: de 
tuldabesteding en de omgeving.

De evaluatie van de tidaberteding is voor belde dimensiles even belangrlik. De verveling, het gevoel niets cedaan te hebben en dat de dagen slechts langzaam voorbilgaan, alsmede net ldee dat de bezlgheden onbelangpljk, onplezierlg, nutiteloos en saal zijn, vormen en essentleel onderdeel van het leven zonder werk, zowel als karakteristlek van het heden als $1 \mathrm{n}$ vergel1jk1ng met het verleden.

Howel de aard en het aantal vercchlllende bezigheden bif belde belev1ngsdimensies minder belangrijk zijn dan hun betekenis als zinvolle tijavuling, spelen zij toch wel eer rol. Meer bez1gheden, en dan vooral de nuttige activitelten in hus en in de buurt, bevorderen rechtstreeks de satisfactie met het dagelijks bestan; de levenshouding belnvloeden $21 \mathrm{j}$ wa hun bljdrage aan de verdrijving van de verveling en het waralologe arrommelen.

Vam de varlabelen die in eerste instantie onder de noemer van de omgeving waren gevat, oefent er slechts één grote lnvloed op de beleving wan het leven zonder werk ult: de soclale 1 solatie. Het gevol dat je overal butem staat nu je niet meer wert draagt byj tot een overwegend onplezierig dagelijks leven en vooral tot een sombere levenshouding.

De mate van vertrouwdheld van de buurt heeft voor de duurgroepen geen enkele invloed op de beleving er op de at1gma-ervaring slechts weinds (b1j 10 manden ten aanzen van de levenshouding).

D1t verschil tussen de soclale 1 solatie en de andere omgevingsvariabelen noopt tot nadere bezinning op hum precleze beteken1s. Duldelijk 1 dat alle omgevingsvarlabelen slechts het oordeel over en niet de abjectleve kermerken van de relatie met de omgeving wergeven. Het versohll tussen subjectieve en objectleve werkelifkheld 1 s bly de soclale isolatie warschijnilyk het grootist en 
b11 de buart het kleinst. Dat w1 weggen dat het covel overal buten te staan heel best tot stand zou kunnen komen zonder dat de omgewing daaraan een recle bljarage Lewert.

Bezlet men de onderlinge samenhangen tussen de omgevingsvarlabelen, dan 11jkt dit inderdaad niet onwarschijnlifk: de soclale lsolatle hangt met geen enkele Wan de andere omgevingsvariabelen (evaluatie van de omgeving, stigma, contacten, buurt) samen. De anderen wertonen wel duldelijke onderlinge relaties, met als zwakste schakel de stigma-ervarling, die daarentegen de hoogste samenhang $(\mathrm{r}=.10, \mathrm{p}=.05)$ met de 1solatiegevoelens laat zen.

Dit alles leldt tot twee conclusies. In de eerste plats 11jkt het erop dat de omgeving in twee clrkels verdeeld zou moeten worden. B1j de burt, de contaden en de evaluatie van de omgewlng is het referentlepunt de vriy nablje omgev1ng: alles bulten het gezln, mar wel 2o dichtbid, dat de mensen in dte omgeving man of meer bekend sijn. De stigma-ervaring en de sociale 1salatie daarentegen referen sterker aan het deel van de matschappij dat door minder persoonjljke, meer anonleme relatles wordt Bekenmerkt, maar war men ".oh bifhoort of bil wil horen.

De tweede conclusie hangt hiermee samen. De soclale isolatie en in mindere mate de stigma-ervaring a in veel. meer subjectieve interpretaties van de relatie tot de matschappid dan het rechtstreekse gevolg van concrete contacten en ervaringen met mensen en instuld1ngur.

Men yoelt zich wel bultengesloten en/or gestigmatiseerd, maa dat hoeft niet in tie houden dat men ook bultengesloten en/of gest1gmatlseero wordt.

Hoe plaustbel de onderlinge onafhankelijkheld van de sublectleve en de objectleve realitelt ook 1s, het laat de vraag onbeantword waardoor de subjectleve werkel1jkheld, met name het gevoel overal buiten te staan, dan wèl tot stand komt. 
U1tsultsel dawomtrent 1 met de in dit onderzoek verzamelde informatie niet te geven. Enkele anwijzingen why er echter wel in de rorm wan de belangrijkste samenhangen met de andere onafhankel1jke variabelen. De soclale tsolatie hangt namelijk op leder moment vooral samen met de evaluatle van de t1jdsbesteding $(-.25 \leq \mathrm{r} \leq$ $-.30)$, de werkwardering $\left(.15 \leq 4^{\text {t }} \leq .23\right)$ en het gezondheldsoordeel $(-.10 \leq r \leq-.22)$ * Kortom: mensen de zlch overal buten wolen gtaan, vervelen zlch meer, voelen zlch nuttelozer, waren teviredener met mun werk, missen hun werk meer en woelem zlich zleker dan degenen die zloh net butitenges loten voelen.

Het gevoel overal buiten te staan lifkt derhalve veel meer dan op de resle relatie met de omgeving gebaseerd op de ervaring af te wlyken var wat nowkal en gewenst 15 . Hilo niet-werker en zleke hoort men niet bij de werkers en gezonden, warblj kennelljk de menter warop men de t1jd doorbrengt als het belangrijkste breekpunt wordt ervaren. Dit $1 \mathrm{~s}$ de reden waram in schema 2 en 3 de soclale 1solatie nlet meer tot de omgevingsvarlabelen 1s gerekend. Overigens mot worden opgemerkt dat deze exegese van varlabele soclale 1 solatie warschijnlijk mede mogel1jk gemaakt wordt doordat in de operational1satie expliclet an het werken wordt gerefereerd: als je niet werkt sta je overal bulten.

\subsection{Overeenkamsten en versahillen tussen de subgroepen}

Leetuld, beroep en atridoenting hebber nast hun $1 \mathrm{n}-$ vioed op de beleving (pag. 85 en 90) ook een gezamenilfke lnvioed op de relaties tussen de beleving en de onafhankelifke varlabelen. Ut de regressie-analyses per subgroep (b1jlage IIIa) biljkt dat de volgorde der belevimgsachtergronden niet voor ledere subgroep lidentiek 1s. Volgens de LISPE-analyse (biglage IIIc) houdt dat echter geen princlede verschilien tussen de regressie- 
structur per subgroep 1m, behalwe na 4 maanden arbeldsongeschikt-zijn ten aanzien van de satisfactie en na 10 manden ten aanzien van de levershouding. In beide gevallen blijkt vooral subgroep 4 te verschillen van de andere subgroepen: bij deze oudere handarbelders met bewegingsaandoeningen is de evaluatle van de tijdsbesteding veel belangrijker voor de satisfactie na 4 maanden arbeldsongesch1kt-zijn dan bij de andere subgroepen en na 10 manden is bil hen de last van de ziekte belangrifker dan bij de rest. 6 )

De verklaring van deze b1jzonder positie van subgroep 4 moet waarschljnl1jk gezocht worden in een comblnatle van nogal negatieve omstandigheden en voorultzlohten: de oudere handarbelders met bewegingsaandoenlngen hebben mér last van de zlekte dan de anderen, minder kans op herstel en minder kans op werkhervating.

$\mathrm{Na} 4$ maanden arbeldsongesch1kt-z1jn beseffen velen van hen derhalve dat $z 1 \mathrm{~J}$ nog gerulme tija, zo niet voorgoed, arbeldsongeschlkt zulien blijven. Voor de meeste arbeldsongeschikten in deze categorle is het arbelisleven teneinde; $z 1, y$ worden dan ook door de GMD met het etiket "elnde arbeldsleven" aangeduld. Vooral op de tijdsbesteding legt dit besef van langdurigheld een zware druk: deze moet het nleuwe leven zonder werk structureren en Inhoud geven (zle par. 7.2). zo bezlen is het dan ook niet verwonder $11 \mathrm{Jk}$ dat hun satisfactle met het dagel1Jks bestaan na 4 manden vooral van de evaluatle wan de tlusbesteding afhangt. Over het algemeen verveelt deze subgroep zich betrekkelijk wakk en acht hil de bezigheden nlet erg wardevol, nuttig en plezieris. De positieve ultzondering daarop heeft directe gevolgen voor het dagelijks bestaran: het wordt er een stuk prettiger door. $\mathrm{Na} 10$ maanden arbelasongeschikt-z1jn is voor de levenshoud1ng b1j stugroep 4 de last van de zlekte belangridker dan bij de andere subgroepen. Binnen de gemiddeld betrekkelijk grote ziektelast van de oudere handarbe1ders met bewegingsaandoeningen, betekent ook hier ledere 
gunst1ge witzondering een wooskleuflger leven zonder werk, vooral daar de verbeteringsperspectleven over het adgemeen niet erg groot $z_{1} \mathrm{j}$, en men de toekomst dus met dezelrae of zelf een grotere hoeveelheld last tegemoet moet $z 1 \mathrm{en}$.

\subsection{Samenvatuing}

De beleving van het leven zonder werk van arbeldsongeschikten moet onderschelden worden in twee aspecten: de satisfactie met het dagel1yks bestaan en de algemene levenshouding.

De erste 1s overwegend negatler. Rond de helit der respondenten reageert op leder moment op minstens drie war de vier uitspraken met de meest negatieve antwoordcategorle: $1 \mathrm{k}$ ga l1ever vardaag aan het wark, het bevalt hler best, de vervelende dingen overwegen, 1 k kan niet doen war eerst geen t1 jal voor was. Slechts 2-4 van de respondenten beantwoordt drie of vier van deze uitspraken positief.

De algemene levenshoudung is veel positlever: elk van de vier ultspraken: Ik heb het zwar te verduren, het leven 1s zo slecht nog nlet, $\mathbb{k}$ zie de toekomst somber in em je vraagt je wel eens af waarvoor je leeft, wordt door minstens de helft der ondervraagden in positieve zin beantwoord. Slechts $8 \%$ van hen antwoordt drie of vier keer negatief".

De achtergmonden voor leder der belevingsvarlabelen zijn global voor de subgroepen en de durgroepen hetzelfoe.

De sachactie met het dagelijks bestaan wordt bovenal door de werkmarderling en de arbeldsorientatie bepaald; de algemene levenshouding in de eerste platis door de erveren saciale isolatie. De tijabesteding neemt bly belde de tweede plats in; het gerin de derde. Howel de (ernst van de) zlekte en de werkhervattings- 
prognose globaal bezien minder belangrifk zljn als achtergrond van de beleving wan het arbeldsongesohikt-zijn, zou het onjulst zijn deze factoren ongenuanceerd te bagmtelliseren. De werkhervattingsprognose heeft immers na 4 manden arbeldsongeschikt-zijm meer invloed op de levenshouding dan alle andere facetten.

Bovendien doet de Invloed van de ervaren zlekte-ernst op de levenshouding nauwelldks onder voor de van de gezinsoms tandigheden.

Overlgens moet wel duldelljk gestela worden, dat de in de analyses opgenomen zlektevariabelem uitslultend betrekk1ng hebben op de ernst van de aandoenlng. Er was geen variabele de op zorgvuldige wilze de ervaring van het zlek-zijn op zich weergaf, zodat geen ultspraken worden gedaan omtrent de lnvioed op de beleving van b1jvoorbeeld de mate warin men het zlek-zijn erg vindt of er een spectfleke betekenis aan hecht (zle par. 7.2). De omgeving blifkt te vermariozen als achtergrond voor de beleving van het leven zonder werk door arbeldsongeschikten.

De verschilien en overeenkomsten tussen de twee belevingsvarlabelen wat betreft hun achtergronden leiden tot de conclusle dat ondanks de overeenkomsten de verschillen de overhand hebben: de satisfactie met het dagel1 jks bestaan en de algemene levenshouding brengen belde welIswaat de ervarlng van het heden als afwljking van het verleden tot ultauklng, mar blj de satisfactle ligt de nadruk op het gemls en de betekenls van het verleden, met name het werk(en), en blj de levenshouding $11 \mathrm{gt}$ het accent wooral op de ervaring van de huldige levensomstandigheden op atch. 


\section{Noten bid hooketak 4}

1. Voor hoofdarbelders (subgroep 5 ; dus in 6 analyaes) zign de kenmerken leftijo en dagnose als onafhankelljke varubelen ingevoerd, teneinde de vergel1jkbaarheld met de andere subgroepen te vergroten.

Ter controle zijn ook stapigew1yze regressie-analyses ultgewoerd. De resultaten daarvan kwamen $1 \mathrm{n}$ grote mate avereen met de multipele analyses; $z i j$ worden daarom niet vermeld.

2. De correlatiematr $1 x$ marop het een en ander $1 \mathrm{~s}$ gebaseerd, 1 opgenomen als bijlage IIIb.

3. B1.j enkele subgropen hebben de burt en ulthulzighe1d wel effect, zie b1jlage IIIa.

4. Dit 11jkt teutologisch, dat w11. zeggen werkgemis = negat1eve wardering van het niet-werken, mar dat is niet het geval. B1J een factoranalyse van de acht warderingsitems plus werkgemis bleek de laatste tot geen van beide waarderingsactoren gerekend te kunnen worden.

5. De soclale 1solatie 1 s vanaf hier los van de amgevingsvariabelen behandeld (zie pag. 100 ).

6. Ook wanneer en andere subgroep verantwoordelijk $11 \mathrm{jkt}$ voor het niet passen van het algemene regressiemodel na 4 en 10 maanden, biljkt dit voort te komen u1t voaral de tegensteliling ten opzlahte van subgroep 4.

Voor de satisfactie (na 4 maanden) $1 \mathrm{~s}$ de last van de ziekte bly subgroep 2 (audere handarbeiders met conditieproblemen) wel en bly subgroep 4 nlet van belang.

Voo de levenshouding (na 10 manden) $1 \mathrm{~s}$ de evaluatie van de t1jabesteding bij subgroep 1 (Jongere handarbelders the conditeproblemen) wel en bij subgroep 4 niet van belang.

Di to betekent dat subgroep 4 óók een tegenstell1ng tussen satisfotie en levenshouding lat zlen: bij de satisfactie wijn de evalutie van de tijasbesteding van méer en de las wan de ziekte van minder belang terwill voor de levenshouding de evaluatie van de tifdsbesteding van minder 


$$
-105-
$$

en de zlekte van méer belang is dan bij de andere subgroepen. 
HOOFDSTUR 5

DE VERANDERINGEN VAN 4 TOT 16 MAANDEN ARBEIDSONGESCHIKT-ZIJN

Dit hoofdstuk is gewlyd aan de vrabstelling sub 2 (par. 3.1) en derhalve aan de eerste vraag de door middel van longltudinale aralysea beantwoord moet worden:

- welke verarderingen treden er in de loop der maanden op in de beleving en de onathankelijke varlabelen;

- ziln er aorzaken voor de veranderingen in de beleving aan te wijzen;

- wordt de beleving na 16 manden arbeldsongeschikt-zijn belnvloed door de ervaringen zoals die na 4 maanden zifn vastgelegd?

De analyses zign nu niet meer verricht op de durgroepen, doch op de driemal gelnterviewden, 74 in getal.

\subsection{De rioht1ng der veranderingen}

In tabel 21 (pag* 107) is voor de categorle drieraal Geinterviewden het gemiddelde en de sprelding van alle variabelen apart voor leder van de drie meetmomenten vermeld. B1j de variabelen die significante verschilien tusien de momenten te zlen geven 1 s aangegeven in welke richting de verandering verloopt ${ }^{1}$.

Duldedjk is dat er slechts enkele varlabelen wezenI1jke versohilien tussen de momenten vertonen. Dat wil ratur 11 jk niet zeggen dat de respondenten ten aralien van de overlge warlabelen allen stablel bllfven; het geeft wechts aan dat blj de meeste variabelen de individuele werateringen ongeveer wen sterk in de ene als in de andere rlohting verlopen. 
Van de beleving en de verschlllende facetten van het arbeldsongeschikt-zijn zullen de veranderingen hleronder besproken worden. 2 )

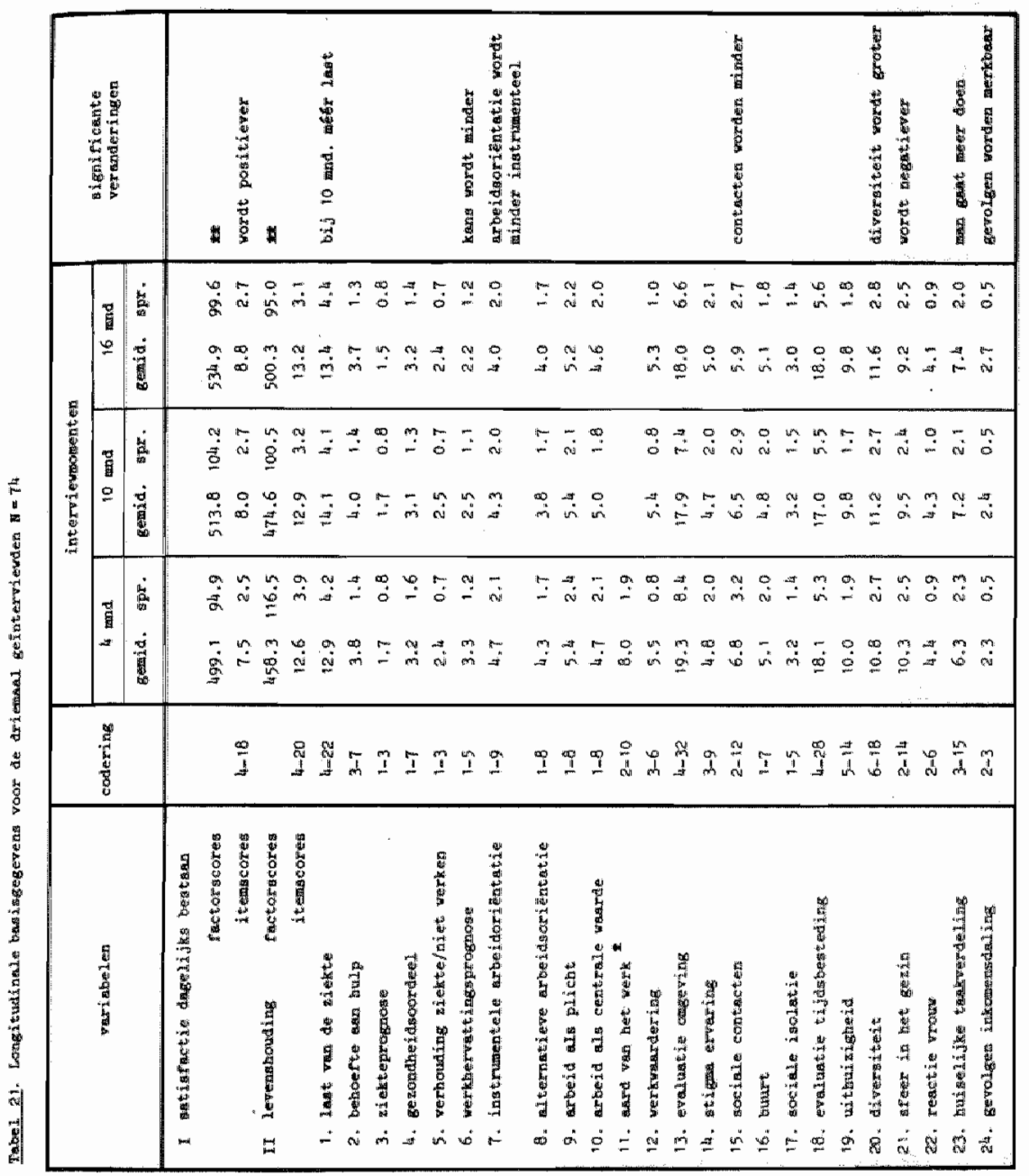


De satisfacte met het dagelifks bestaan verandert dulcelljk in postheve zin: het gaat allemal beter bevallen en de prettige dingen krljgen meer gevicht tegenover de vervelende. Deze plezlerige veranderinger gaan nlet allemal vergezeld van wergelijkbare wijzingen in de lewenshouding; deze wordt gemiddeld wel lets mar niet sgniflcant posituever.

Wat betreft de aandoening treden geen essentiele verschulvingen op var 4 naar 10 en var 10 naar 16 maanden, hoewel de last die men van de zlekte ondervindt (p1jn, vermoliheld, last blj lopen, total aantal klachten) over het ajgemeen eerst toe en dan afneemt.

Werkhervatuling wordt in de loop der maanden steeds $\mathrm{min}$ der warachijnlijk geacht, warmee men erkent dat de elgen positie op de arbeldsmarkt, afgezien var de eventuele veranderingen in de gezondhe1d, steeds ongunstiger wordt.

Van de visle op (het) werk(en) verandert alleen de 1nstrumentele arbeldsorientatie: werken mordt minder een noodzakelljk kwad en een middel om geld te verdienen. Aangezien dezelfde tendens bij de alternatleve arbeldsoriëntatie warneembaar 1s, vooral gedurende het eerste half Jaar, kan gesteld worden dat werken in warde toeneemt, als men na enlge tijd ontdekt dat men méér mist dan het inkomen, dat lmmers door de ultkering (grotendeels) wordt vervangen. Dit lijkt nlet te moetien worden opgevat als 1deallserlng van het werken mar als een aan den lijve ondervinden wan de betekenis die werken had. Ind1en 1deal1serlng op zou treden, dan zou toeneming van de werkwardering kunnen worden verwachten, en dat is nlet het geval; althans niet vaker dan het tegendeel.

Wat betreft de relatie met de omgeving bilykt de endge duldelike verandering te bestaan ult het verminderen van de contacten met famile, vrienden en kennlisien. Hidervan blijkt met name de daling in de contactrequentie met vrienden en kennissen debet te zijn.2)

Dit wordt alechts gedeeltelifk meersplegeld in de evalu- 
atle van de ongeving, die van 4 tot 10 manden lets, mar niet signiflcant negatlever wordt het gewoel overal bulten te staan als je niet meer werkt wordt (nlet door het aantal contacten of de verandering daarin beinvloed) ongeveer even vaak sterker als minder sterk.

De t1jdsbesteding bl1jkt te veranderen wat betweft het aantal verschlilende bezigheden $1 \mathrm{n}$ en om het huls (alversitelt). Dit blijkt vrilwel ultslutend veroorzaakt te worden door de toename van de hulshoudel1jue bezigheden (en een beetje door de toename van rburenhulp": klusjes, babysitten, raad en daad).

De evaluatle van de tijdsbesteding verandert in de loop der tijden nlet grondig, hoewel er wel enige versohilien aan de dag treden. Na 16 maanden arbeldsongeschikt-zijn 1s de verveling over het algemeen lets minder ernstig dan na 4 en 10 maanden, mar daartegenover staat dat men de bezlgheden wel duldelijk minder plezlerig, leuk, boelend, afwisselend, wardevol, nuttig en/of bejangrijk 1s gaan vinden.

Vergeleken met de andere facetten van het leven zonder werk verandert er in het gezin van de arbeydsongeschlkten veel. De sfeer in het gezin wordt negatiever, niet zozeer doordat er meer moell1jkheden of spanningen ontstaan, als wel doordat de gezelligheld, saamhorlgheld, vrollykheld en levendigheld afnemen.

Dezelfde tendens is te constateren voor wat betreft de reactie van de vrouw, zoals die door de man ervaren wordt. zif gat ziln thuis-zijn minder prettig vinden, doch voor z1jn gevoel leddt dat niet tot meer onder linge spanningen (voor haar gevoel echter wel).

Een van de redenen warom de vrouw de permanente hulse11jke aanwezlgheld wan de man minder gaat watrderen 1 s dat hij zich steeds meer met hav werkterreln gat bemoelen. H1J gaat niet alleen meer in het huishouden doen, maar bepaalt ook meer wat er gedaan moet worden, neemt meer beslissingen over de besteding van het hulshoudgeld en regelt ook meer van de grotere geldzaken. 
Dit lateste 1 s net van belang ontbloot, daar in toememende mate de tering nar de nering gezet moet worden: de gevolgen wan de daling van het gezinsinkomen worden, voral na de overgang van de ziektewet naar de WAO lae wektewet-h1tkering word door vel werkgever a angevula tot 100: war het laatstwerdende loon; de WA-ultkering mestal niet) duidel1jk meer merkbar.

Alieg blj elkar moet worden vastgesteld dat het merendeel van de a igniflcante veranderingen gedurende het onderzoeksjear in negatleve rlchting verloopt: het leven zonder werk is voor arbeldsongeschikten in wele opzlchten minder aangenaam naarmate het langer duut. Daardoor 1 s het deb te opvallender, dat de satisfactie met het dagelifkse bestaan in de loop der maanden julst toeneemt en dat ook het optlmume in de algemene levenshoud1ng gemideld lets, z1y het niet stgniflicant, toeneent.

Deze paradax zal verklarbaar bl1.jken als in de volgende paragraaf de achtergronden van de belevingsverander ingen nader bestudeerd $z 1 j$.

5.2. De achtergronden van de verander 1 ngen $1 n$ de beleving var het arbe1dsongeschikt-zijn

B1f het zoeken naar een verklaring voor de veranderingen in de beleving van 4 tot 16 maanden 11 gt het voor de hand in de eerste plats te kdjken naar de invioed van de belev1ng na 4 maanden op deze veranderingen. De overwegand positieve veranderingem in de satisfacte bljwootbeeld zoliden Iminers veroorzakt kunnen worden door de overwegend negatieve anwangsituatie.

Deze regressie nar het gemidelde - negatieve scores worden positlever en positleve scores negatiever - is een bekend verschisnsel en blijkt (ult hie niet weerceGeven krustabelien) Inderdaad bil de belevingaverandeningen een belangrijke rol te speler. 
Het audelljkst is dat het geval bil de levenshouding: hoe somberder ae levenshouding na 4 manden, hoe vaker er positleve veranderingen optiseden van 4 tot 16 maanden en hoe groter deze over het algemen $21 \mathrm{yn}$. Evenzo treden er meer en grotere negatleve veranderingen op na een optimistische levenshouding in het begin.

Hoewel er lets meer positieve dan negatieve veranderingen optreden $(50 \%$ van de respondenten wordt optimistischer, $39 \%$ sombercer, 11\% houdt dezelfde score) ${ }^{3)}$ houden zif elkar, mede door de grootte der veranderingen, in evenwicht.

De regressie naar het gemiddelde treedt ook op bij de satisfactie met het dagelijks bestar, echter nlet geheel symetrisch.

De laagste beg1nsat1sfactlecategor leän worden wellswar uitsiuitend positiever van 4 tot 16 maraden, doch de mensen in de hogere satisfactiecategorleen (het onderscheld ligt hier op de mediaan) worden niet ultslultend en zelfs niet overwegend negatiever. Er is dus een positleve tendens voor alle respondenten; een zeer sterke voor degenen ale in het begin niet tevreden met hun dagelijks bestaan zljn en een lets zwakhere voor de meer tevredenen. In totaal wordt de satisfactie b1y $62 \%$ pos1tlever, b1j 19\% negatiever en bl1Jft z1j gelijk b1j $19 \%$ wan de driemal geinterviewden. 3 )

In een poging de achtergronden van de belevingsveranderingen te antdekken zijn verwolgens twee regressieanalyses u1tgevoerd, warb1j de veranderingen wan 4 naar" 16 manden in de twee belevingsimensies zifn gerelateerd an de weranderingen in de 24 onathankelithe verabelen, alsmede aan leeft1jd, beroep en a andoeng1ng. 4 ) Uit deze andyses blifkt dat de veranderlngen in de satisfactle met het dagel1 $\mathrm{ks}$ bestaran en $1 \mathrm{n}$ de levenshouding met geen der veranderingen 1 in de achtergrondvarlabelen samenhangen. Er zijn noch significante

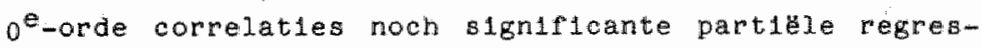


siecoefilclenten. Dok de multpele correlatiecoefflelenten zisn niet significant (alles bija $a \leq .05$ ).

De 1 paragraaf 1 geconstateerde tegenstelling tussen de regatieve ontwkelingen in de verscheldene facetten van het abeidsongesch1kt-z1,n en de positieve verschulving in de belleving van het leven zonder werk door arbeldsongeschlkten lifkt derhalve verklaard te moeten worden door het felt dat belde veranderingen zich vrijwel geheel 108 van elkaar voltrekken. Een verbazingwekKende conclusie, die ook niet helemaall bevrealgend $1 \mathrm{~s}$. Nadere analyse van de samenhangen tussen de diverse veranderingen 1 s daarom gewenst.

De kruistabellen van de verschulvingen in de onafhankelijke variabelen met de veranderingen 1 in de belewing vertonen het volgende beeld. Over het algemeen gaan posltheve ontwikkelinger in de facetten van het leven zonder werk wel gepard met positieve ontwlkelingen in de beleving, doch negatieve facetveranderingen hebben veel minder negatieve en valk zelfs ook positieve gevolgen. Dit geldt zowel de onafhankelijke varlabelen die een overwegend negatieve verschulving te zien geven (tabel 2l) als die, welke transversaal sterk met de beleving bleken samen te hangen (hoofdstuk 4).

Dit verschlinsel roept de viaag op naar andere factoren, die de negatleve effecten van de verslechterende stuatie in de diverse facetten verzachten of zelf positleve zin overtreffen. Mogel1jk zijn hier een tweetal psyohologlsche en wezenl1jk tijdgebonden mecharismen in het geding: gewenning en aanvarmding. Dit $z i \mathrm{Jn}$ twee begrippen die vooral in de (engelstalige) literatur betreffende de aanpasing aan zlekte en handicap gehanteerd worden als belangrljke fasen in he "coplng proces", z1J net zonder duldelljke definitie. Gewenning wordt meestal opgevat als een automat1sch gevolg van het verstrijken van de tijc: Je went vrifwel overal aan, als je mar lang genoeg mee te maken hebt (o.a. V1sotsky 
e.a. 1961). Met aanvarding wordt het proces bedoeld, warin de verwerking van het leed (zlekte, werkloowheld, een ander probleem) een auddelijk positleve wending neemt. Sllier (o.c.) noemt het "acceptance (of loss) whout personal devaluation": het probleem blifft wel bestaan, mar men wordt er niet in de hele persoonl1 $1 k-$ held door aangetast. Het beinvloedt het leven, maar riet op allesoverheersende wijze.

Een (minder positleve) vorm van aanvaraling is berusting: men legt zloh bij het onvermijlelijke neer. maar meer ook niet. In termen van de copingtheorleen: passieve, in tegensteling tot de beter (= effectiever) geachte actleve coping (Lazarus 1966, Dirken 1969). Het moge$11 \mathrm{jk}$ belang van deze mechantsmen in a1t onderzoek wordt gejulustreerd door het felt dat ruim de helft van de respondenten, bij 10 en 16 maanden gevraagd naar de belangrijkste veranderingen in bun leven in het aftgelopen half jaar, antwoordden: "1k ben er een beetje aan gewend" "ik heb er in leren berusten", "als je je schikt in het onvermijolifke is het al wat beter uit te houden" en dergelljke. 5) Fen dergelilk antwoord werd veel vaker gegeven dan de antwoorden betreffende meer tastbare veranderingen, zoals bifvoorbeeld verbetering of achteruitgang, in de aandoening.

Gewenning en anvaarding verandemen vanzelfisprekend niets aan de concrete speclfleke omstandigheden, maar zil kunnen wel de globale perceptie daarvan belnvloeden: ten opzlchte van de vroegere en de gewenste amstandigheden kan het heden in $z^{\prime} n$ totalited als minder schrijnend worden ervaren.

Hoewel het platusibel. 11jkt dat gewenning en arvaarding de veranderlmgen $1 n$ de beleving van het arbeldsongeschikt-zidn beinvloeden, is onduldelifk waarom deze Invloed zlah in de satisfactle- en nauwelijksi in de belevingsveranderingen zou manifestem. 


\section{3* De linvloed van de ervarlngen na 4 manden on de beleving na 16 manaen}

Deze paragraf behandelt de vraag of de beleving van het arbeldsongeschtk-zin na 16 matinden een jaar tevoren al enlgins voopspeld kan worden.

Ter beantwording van deze rag zifn allereerst de belevingsacores na 4 maanden vergeleken met de belev1ngsares na 16 malanden.

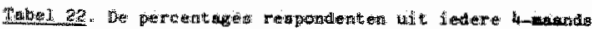

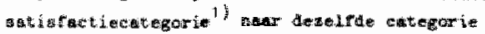
vis 16 arand

\begin{tabular}{|c|c|c|c|c|}
\hline \multirow{2}{*}{ 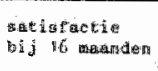 } & \multicolumn{4}{|c|}{ 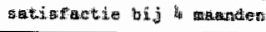 } \\
\hline & $4-5$ & 6 & $\pi-8$ & $9=10$ \\
\hline $14-5 \Rightarrow$ nag & 13 & 8 & 13 & 0 \\
\hline 6 & 19 & 23 & 16 & 0 \\
\hline $7-8$ & 43 & 46 & 25 & 10 \\
\hline $9-10=000$ & 25 & 23 & 466 & 90 \\
\hline Toteral & 100 & 9000 & 100 & 100 \\
\hline $\mathrm{N}=$ & 16 & 3 & 24 & $2: 1$ \\
\hline
\end{tabular}

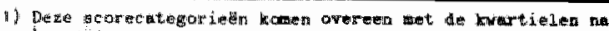
4 miander.

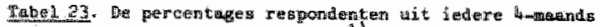

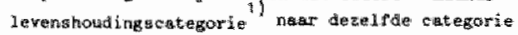
bi.j 16 rigiander.

\begin{tabular}{|c|c|c|c|c|c|}
\hline \multirow{2}{*}{\multicolumn{2}{|c|}{$\begin{array}{l}\text { levenghouding } \\
\text { bij } 16 \text { wander }\end{array}$}} & \multicolumn{4}{|c|}{ Levergetbouding bij 4 mabidm } \\
\hline & & $3-10$ & $1: 12$ & $13=15$ & $16-20$ \\
\hline \multicolumn{2}{|c|}{ 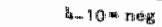 } & 43 & 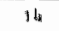 & 10 & 5 \\
\hline \multicolumn{2}{|c|}{$1 \eta_{i-2} 1: 2$} & 9 & $2 c^{2}$ & 20 & 16 \\
\hline \multicolumn{2}{|c|}{$1 y-15$} & 29 & 0 & 60 & 32 \\
\hline \multicolumn{2}{|c|}{ 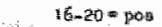 } & 19 & 14 & 40 & 47 \\
\hline \multirow[t]{2}{*}{ forctand } & 5 & 100 & 100 & 100 & 100 \\
\hline & $N=$ & 21 & 14 & 20 & 19 \\
\hline
\end{tabular}

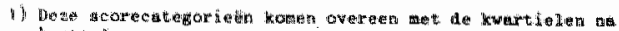
to 
U1t bovenstaande tabellen wordt duldelljk dat voorspelling van de elndbeleving vanult de beleving van 4 maanden arbeldsongsohlkt-z1jn mogel1jk $1 \mathrm{~s}$, zij het niet met grote exactheid.

Voor drle van de vier aanvangscategorleen geldt dat meer dan $2 / 3$ van de desbetreffende mespondenten na 16 maanden in dezelfde of een naast gelegen, meestal hogere; categorle terecht is gekomer. Alleen vanult de laagste belewingscategorie overschrljden de (positieve) veranderingen meestal meer dan één categorle.

ook de correlatiecoefficiënten van de satisfactie en de levenshouding bij 4 maanden met die b1j 16 maanden laten zien dat er een duldelijke, doch niet zeer grote samenhang tussen de begin- en elndbeleving bestat: voor de sat1sfactie 1 s de $r .60$, voor de levenshouding.46 (belde $p(.05)$.

Het spreekt echter vanzelf dat de beleving van 16 maanden arbeldsongesch1kt-zijn niet alleen kan afhangen van de vroegere beleving, maar ook van de verschiliende facetten van het leven zonder werk, zoals die er in het begin, dat wil zeggen na 4 maanden ultzien.

Derhalve $z 1 j n$ er wederom twee regressle-analyses ultgevoerd, van de ulteindelijke beleving als afhankel1jk varlabelen op de beleving plus de 15 onafhankelijke varlabelen bij 4 maanden, alsmede leeftija, beroep en aandoenlng (totaal 20 onafhankelifke varlabelen).

Het resultat is als voligt.

66\% van de varlante in de satisfatie na 16 manden wordt verklaard door de gezamenllyke onarhankelljke varlabelen bif 4 manden. Hiertoe dragen vooral de satisfactie, de mate van ulthulatgheld en de instrumentele arbeidsorientatie in het begin bly $(\beta=$ resp. $.28,-.27$ en .26).

Er zijn meer beginvariabelen die een sterke samenhang met de elndsatisfactie vertoner, bljvaorbeeld de werkwarderlng, de soclale isolatie en de tijdsbesteding, 
maar deze doen hun 1nvloed op de elndsatisfactle slechts gelden via de beleving na 4 manden.

ook ae levenghouding na 16 manden arbeldsongeschlkt-z1jh wordt door de gezamenl1jke vroege ervaringen belnvloed: de verklaarde varlantle $1 \mathrm{~s} 42 \%$ (slgniflaant b1j $\leq .05$ ). Mu zin er echter geen varlabelen, die een duldelifke onathankelijke invloed doen gelden. De levenshouding, de last van de zlekte, de arbeldsorientatie, de tijdsbesteding en het gezin, allen zoals ervaren na 4 maanden, hangen wel samen met de levenshouding ria 16 maanden, mar ultsiultend in onderling verband; er 21 jn geen signiflcante B-coefficienten.

De conclusle luldt dat de beleving van het arbeldsongeschikt-zijn ne 16 manden geworteld 1s in de ervaringen na 4 maanden.

Voor de satisfactie geldt dat er enkele duldel1jke woorspellende factoren herkenbaar zijn, voor de levenshouding echter ntet.

Een ander versch1l tussen de twee belevingsimensies vormt het felt dat op de ulteindelijke satisfactle de invloed van de 4-maandssituatie sterker $1 \mathrm{~s}$ dan de $1 \mathrm{n}$ vloed van de gelifkt1jdge (16 maknds)facetten van het a beldsongeschikt-zily, terwljl op de ultelndelijke levenshouding daarentegen de 4-maandssituatie fulst minder Invloed heeft. ${ }^{6}$ ). Dit komt overeen met het feit dat de satisfactie van 4 tot 16 manden lets stableler blijkt dan de levenshouding.

\section{4. Samenvatt1ng}

In alle afhankelijke en onafhankelijke varlabelen treden in de loop der maanden veranderingen op, die als verbetering of verslechtering van het leven zonder werk ven arbeldsongeschikten kunnen worden opgevat. B1J 16 onafhankel1jke varlabelen houden de negatieve en pos1- 
tleve ontwlkkelingen elkaar ongeveer in evenwicht: gemiddeld houden $z i j$ bij 4,10 en 16 maanden dezelfte waarde.

Dit is niet het geval b1j 8 onafhanke11jke, waarvan de veranderingen grotendeels als overwegend negatief kunnen worden gekenschetst.

Des te oprallender is het felt dat de satisfactie met net dagelljks bestaan, en in mindere mate ook de algemene levenshouding, in de loop der maanden positlever wordt.

Deze tegenstelling blijkt te kunnen worden verklaard door het felt, dat de veranderingen in de beleving zich vrljwel geheel los van de veranderingen in de onderzochte facetten van het leven zonder werk voltrekken.

Wellswaar hangen positieve veranderingen in de beleving meestal samen met positieve facetveranderingen, maar a $1 \mathrm{j}$ hangen eveneens dikwijls samen met negatieve facetveranderingen.

Hoewel de veranderingen in de beleving in zekere mate gebaseerd blijken op de ultgangsbeleving (na 4 maanden arbeldsongesch $1 \mathrm{kt}-z 1 \mathrm{jn}$ ) is dat geen voldoende verklaring voor de positieve tendens die er blj zeer vele respondenten in de satisfactie zichtbaar $1 \mathrm{~s}$.

A.ls mogel1yke aanvullende verklaring zou kunnen worden gedacht aan de invloed van gewenning aan en aanvaarding van het arbeldsongesch1kt-z1jn; mechanismen die in de loop der maanden de werkelifkheld een plezleriger aanzlen geven ondanks de nog aanwezige of groelende onplezlerlge kanten ervan.

Zowel de satisfactie als de levenshouding na 16 maanden arbeldsongeschlkt-zijn blijken, zlj het nlet exact, voorspelbaar vanult de ervaringen na 4 maanden. Voor de uiteindelijke satisfactie is zelfs de 4 maandssltuat1e belangrijker dan de omstandigheder na 16 masuden. 


\section{Noten b1j hoofdatuk 5}

1. De nlveauverschilien tussen de momenten werden getoetst met een tweevoudige varlantie-analyse. De richting van de veranderingen door middel van een polynoomanpassing (SPSS, tests for trends).

2. In deze paragraaf 1 is gebrulk gemaakt van enkele gegevens betreffende de veranderingen in de varlabelen en items waarult de onafhankeliyke wariabelen zljn samengesteld. Deze waren ten behoeve van het tweede MIPG-verslag geanalyseerd (1977).

3. Slechts $7 \%$ van de respondenten houdt na 4,10 en 16 maanden exact dezelfde satisfactlescore. De score levenshouding is bif nlemand drlemal dezelfde. Overlgens wijkt het globale beeld van de veranderingen van $4+10$ en $10+16$ maanden niet af van het in de tekst beschreven beeld van $4+16$ maanden.

4. De veranderingen van 4 tot 16 maanden $z 1 j \mathrm{jm}$ voor vrijwel alle varlabelen omgescoord tot een 7-puntsschaal.

De mlddencategorle betreft de absolute gelijkblifvers en de veranderingen tot en met maxlmal + of $-1 / 10$ van de oorspronkel1jke schaal. De categorleën + of $-1,2$ en 3 betreffen veranderingen van $1 / 10 \mathrm{t} / \mathrm{m} 2 / 10,2 / 10 \mathrm{t} / \mathrm{m} 4 / 10$ en $>4 / 10$ van de oorspronkelijke schaal.

5. Deze open vraag kon helaas niet als varlabele worden opgenomen, daar de weergave van de antwoorden door de interviewers niet volledig was.

6. Voor de satisfactie 1 s de multipele $r$ na 16 maanden .67 voor de drlemal geinterwiewden $(N=74)$ en .59 voor de totale duurgroep $(N=387)$. De percentages verklaarde varlantle zijn derhalve 45 en $35 \%$.

Voor de levenshouding $z 1 j n$ de desbetreffende c1jfers .71 en .57 , dat w11 zeggen 50 resp. 33\% verklaarde variant1e. 
HOOFDSTUR 6

WERSOHILLEN TUSSEN DRIEMAAL OEINTERVIEWDEN EN WERKHERVATMTRS

De vragsteling sub 3 luidde (par. 3.1): wijn er na 4 maanden arbeldsongeschlktheld verschlilen te constateren tussen de arbeldsongeschiten die het 16-mands interview Zulien meemaken en degenen die hun werk hervatten na het 4-maands interview?

Het meer algemene probleem wan de voorspelbaarheld van bllivende arbeldsongeschiktheid wordt door deze vraag welismar lang niet volledig "gedekt", maar" het in dit hoofdstuk te geven antwoord werpt er toch enig licht op. In dit verband is het echter van belang de beperkingen van de steekproef ondex meer naar alagnose en nar geschatte langaurigie1a - en van het onderzoeksmateriabl - allëén de mening van de betrokken arbeidsongeschikten over het arbeldsongesch1kt-zijn, dus niet toegespitst op het arbeldsongeschikt-blyjwen - in gedachten te houder.

De twee te vergelijken groegen respondenten bestaan wit 74 driemal geinterviewden (or mblijvers") en 145 werkhervatters. 1$)$

\subsection{Verschi1len 1n basiskenmerken}

Bl1jwers en werkhervatters zijn allereerst vergeleken ten aanzien van leeftijd, beroep, aandoening, reglo, provincie en urbanisatiegrad. De blijvers blijken ouder. vaker handarbelders, met name ongeschoolde, vaker $11 j$ dend onder beweglngsmoeliljkheden, vaker ult het oosten (overijsisel en Gelderland met rame) en minder vaak u1t het zuiden (met name Limburg) afkomsty dan de werkhervatters. Tussen werkhervatters en blifvers werd geen versobli ten aanzlen van de urbanisatiegraad vari de woongemeente geconstateerd. 
Een verklaring van de eerste drle verschlilen ligt voor de hand: (ongeschoolde) handarbelders en ouderen nemen, afgezlen van en eventuele handicap, op de arbeidsmarkt een minder aterke positie 1m. Daar komt nog byj dat ouderen en mensen met beweglingsaandoeningen in ernstiger. mate gehandicapt $z 1 \mathrm{gn}$ (meer last van de aandoening, vaker het gevoel niet gezond te $z 1 \mathrm{y}$ ) dan fongeren en thensen met beperkingen in het uithoudingsvermogen, hetgeen hun werkhervatting niet vergemakkelljkt. Kortom: oudere handarbelders met bewegingsmoel11jkheden hebben de meeste kans op langdurlge arbeldsongeschiktheld. In tabel 24 is dit ook duldellyk zlchtbaar. Deze ciffers laten eveneens zlen, dat vooral b1 de Jongere hoofdarbelders veel werkhervatters voorkomen.

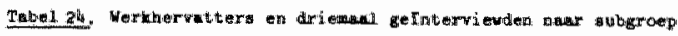

\begin{tabular}{|c|c|c|c|c|c|c|}
\hline subgroeppen & \multicolumn{2}{|c|}{ werkherwatten } & \multicolumn{2}{|c|}{ 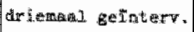 } & \multicolumn{2}{|c|}{ tot } \\
\hline & abs & $\begin{array}{l}\text { rij pet } \\
\text { tolom pent }\end{array}$ & Alos. & $\begin{aligned} \text { rig pet } \\
\text { waldon pet }\end{aligned}$ & abs & $\begin{array}{r}\text { rij pet } \\
\text { kotam pot }\end{array}$ \\
\hline 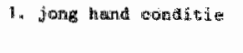 & 27 & $\begin{array}{l}73 \\
79\end{array}$ & 10 & $\begin{array}{l}27 \\
14\end{array}$ & 97 & $\begin{array}{r}100 \\
17\end{array}$ \\
\hline 2. obid thend concitite & 27 & $\begin{array}{l}63 \\
19\end{array}$ & 16 & $\frac{37}{2.2}$ & 43 & $\begin{array}{l}100 \\
80\end{array}$ \\
\hline 3. jong hand bewesing & 27 & $\begin{array}{l}68 \\
19\end{array}$ & 13 & $\begin{array}{l}38 \\
38\end{array}$ & 40 & $\begin{array}{r}100 \\
28\end{array}$ \\
\hline 4. Oud hend beveging & 14. & $\begin{array}{l}39 \\
10\end{array}$ & 22 & 91 & 36 & $\begin{array}{r}100 \\
115\end{array}$ \\
\hline 5. jons poord conditio & 186 & 1.1 & 3 & $\begin{array}{r}16 \\
4\end{array}$ & 19 & $\begin{array}{r}100 \\
0\end{array}$ \\
\hline 6. oud hoofd conditite & 13 & $\begin{array}{r}16 \\
9\end{array}$ & 4 & $2^{44}$ & 17 & 100 \\
\hline 7. fores boort beweging & 12 & 86 & $e^{\prime}$ & $\begin{array}{c}1 \text { 侢 } \\
3\end{array}$ & 14 & 100 \\
\hline a. joute hoofd veregigh & 9 & 69 & 4 & $3 \cdot 4$ & 13 & 100 \\
\hline Tottual & 14 & $\begin{array}{r}66 \\
100\end{array}$ & $7 \mathrm{ig}$ & $\begin{array}{r}34 \\
100\end{array}$ & 219 & $\begin{array}{l}100 \\
100\end{array}$ \\
\hline
\end{tabular}


De vraag hoe het komt dat in Gelderland en over 1 issel relatief veel driemal geinterviewden vook komen en in Limburg Julst relatief weel werkhervatters is arm de hand van het beschikbare material niet te beantwoorden. Wat Limburg betmeft is het echter niet onwarschilnd $1 \mathrm{Jk}$ dat de oorzaak van bet relatief grote aantal werkherwatters gezocht moet worden in een door soeters (1980) geslignaleerde blyzondere samenstelling van het zlektewetbestand in Zuld-Limburg. Hij constateerde dat in het (herstructureringsgebled) zuld-Limburg het middelang verulim (van 43 tot en met 91 dagen), zowel wat het aantal zlektedagen als het aantal zlektegevalien betreft, aammerkel1jk hoger is dan in de rest wan Nederland. Voor het korter en langer durend verzulm geldt dit niet. Deze oververtegenwoordlging wan middellange verzulmers, heeft warschijnlijk doorgewerkt $1 n$ de onderzoekspopulatie en in de steekproef van 10-weeks gevallen. Als gevolg daarvan wordt de oververtegenwoordiging van werkhervatters tussen 91 en 366 dagen in zu1d-Limburg weerspiegeld in dit onderzoek in het grote astal werkhervatters na het eerste interview in die provinole.

\subsection{Verschillen in onderzoekvartabelen}

Het ligt woor de hand om blj de vergeldyking var de werkhervatters en drlemal gelnterviewden tien aanzien van de afhankelijke en onafhankelijke variabelen rekening te houcen met de invloed van leeftida, beroep en aandoening *

Deze basiskentierken laten 1 mmers effecten zien zowel op de werkhervatting o.q. het driemal gelntervlewd worden als op de varlabelen; effecten die derhalve bly de beoogde vergelljking een rol spelen. Besloten werd om de invloeden var leeftild, beroep en abudoenting op twee manleren te werrekenen: 
* door het opmemen van leeftlj, beroep en aandoening als onafhankel1jke varlabelen naas de 24 basisvarlabelen en de twee belevingsimensies, zoals gemeten na 4 maanden arbeldsongeschikt-z1jn. Middels een regressle-analyoe van de 145 werkervatters en 74 blifvers kunnen deze groepen aldus vergeleken worden ten aanzien van 29 kenmerken;

b. door matching van de werkhervaters en drlemal geinterviewden naar subgroep, waabil voorop stond dat de te formeren subgroepen zo groot mogellik dienden te z1.jn. Deze werkw1jze resulteerde in twee groeper van elk 66 respondenten, te weten alle driemal geinterviewden min 8 ult de subgroep hand - beweging - oud (zle tabel 25) en 66 werkhervatters, in dezelfde verhoudingen verdeeld over de subgroepen als de driemal Beinterviewden.

op deze groepen werd een regressle-analyse ultgevoerd met de 24 basisvarlabelen, de twee belevingsalmenales, plus leeftijd en beroep? ${ }^{2)}$, derhalve met 28 kenmerken.

Belde benaderingen leverden gratendeels ldentieke resultaten op; wat betreft twee eventueel belangrijke onderscheldende kenmerken tussen werkhervatters en bl1jvers was dat echter niet het geval. Daarom zijn in tabel 25 (pag. 123) belde regressleresultaten vermeld.

In tabel 25 valt allereerst op dat leeftid, beroep en aandoendng géén rechtstreekse invloed op het al dan nlet hervatien van werk uitoefenen. Zly doen hun lnvioed Indrect gelden, via de zlekteprognose (beroep) en de werkhervattingsprognose (leeft1ja) of via de hulpbehoefte en de last van de ziekte (aridoening) die op hun beurt met het gezondheldsoordeel de prognoses mee beInvioeden (zie schema 5, pag. 125).

Welke van deze en de andere onafhankelljke varlabelen nu de beste voorspellers zijn voor het al dan niet langdu- 
18 arbeldsongeschlkt-blijven komt ult tabel 25 ntet eenduld $1 \mathrm{~g}$ nar voren.

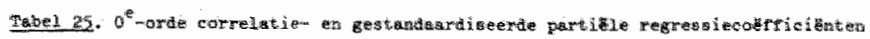

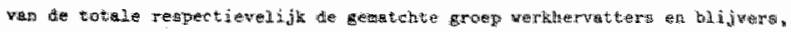

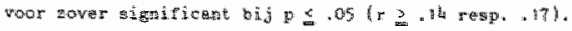

\begin{tabular}{|c|c|c|c|}
\hline \multirow[b]{2}{*}{ 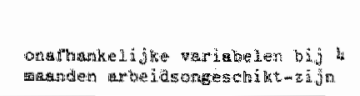 } & \multicolumn{3}{|c|}{ 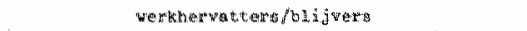 } \\
\hline & 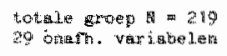 & \multicolumn{2}{|c|}{ 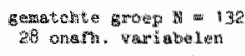 } \\
\hline & 8 & $\because$ & B \\
\hline 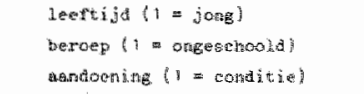 & $\begin{aligned} .23 & (.01) \\
-.19 & (-.09) \\
(.12) & (.03)\end{aligned}$ & $\begin{array}{l}(.08) \\
(-., 05) \\
\mathrm{a}+\mathrm{w}+\mathrm{c}\end{array}$ & $\begin{array}{l}(-.03) \\
(-.02) \\
n .4 .6 .\end{array}$ \\
\hline If levershouting & -.33 & $-n 30$ & \\
\hline H. Last ven de zigekte & .26 & .99 & \\
\hline 2. behcerte den hulp & .22 & . $3 \mathrm{H}$ & .23 \\
\hline 3. riekteprognoge &,- 4 & $-.4 \pi$ & $-\ldots 24$ \\
\hline 4. sezonitheid soortaed & -.29 & -.30 & \\
\hline 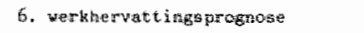 & -.43 & $-3 E$ & $(-, 1 y)$ \\
\hline 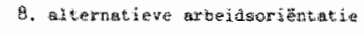 & $(.08)$ & 20 & 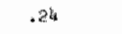 \\
\hline 10. arbeid abg contrade warde & .15 & & \\
\hline 13. evalutide omering & -.15 & & -.26 \\
\hline 19. Bosithe contacten & .17 & & .29 \\
\hline 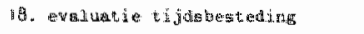 & -.15 & & \\
\hline $2^{\text {H. }}$ gevolgen ingomengdaline & -.18 & & \\
\hline mutipelar & .61 & & .67 \\
\hline
\end{tabular}

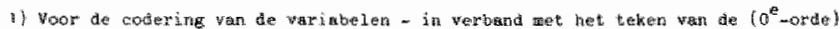

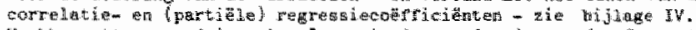

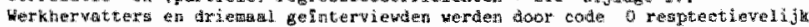

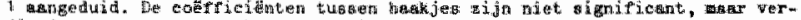

dienden wet het oog op hun betekenit toeh vermelding.

Duldel1 $\mathrm{jk}$ 1s wel dat de langdur $1 \mathrm{~g}$ arbeldsongeschiktem al vroeg te herkennen $z i j n$ aan een grote behoefte aan hulp, een geringe kans op (volledig) herstel van de zlekte, een negatief oordeel over hun ongeving en een grote hoeveelheld contacten, vooral met familieleden.

De timee analysestrategleén stemmen echter njet overeen wat betreft het belang van de invloed van een ongunstige werkherattingsprognose en een alternatieve arbeligorlentatie op het arbe1dsongeschlkt-blifwen.

Overigens is het te verwachten dat twee analyses betreffende verschillende selectles ult eenzelfde groep 
tespondenten niet exact ldentike resultaten opleveren. Door en mer homogene samensteliling van een kielnere selectle, in dit geval de gematchte groep, worden de correlaties over het algemeen lets hoger, zodat aanwez1ge verbanden sterker naar voren komen hetgeen als een woordeel wan deze strategle kan worden beschouwd.

Een bezwar is echter, dat de betrouwbarheldanterwallen van de correlaties groter worden, hetgeen inhoudt dat in een multivarlate analyse min of meer toevallige verbanden een crotere kans kn 1 jgen om als slgniflcant ges 1 gnaleerd te worden.

Hoewel over deze materie vanult statistisch/methodologisoh oogpunt nog zeer veel meer op te merken zou zifn, kan hier worden volstaan met enkel conclusies, die voor de Interpretatie van de gevonden overeenkomsten en verschilien tussen de ultkomsten van belde analysestrateBleën wan belang zijn.

- Het gemeenschappelijk resultaat van de analyses b1y de gematchte en de totale groep kan men als betrouwbaar resultak beschoulwen;

- teneinde aan de voorzlchtige kant te blijwen, en een toevall1s resultaat nitet als betroumbar te bestempelen, kan men an de litkomsten van de analyse op de grootste $N$ lets meer warde hechten dan aan die, welke b1J de klelnere $N$ gevonden worden;

- een significante relatie binnen de gematchte groep duldt echtier ook op een mogel1 $\$$ k reèel verband.

Terugkerend naar de reeds genoemde analyseresultaten bl1jkt de tweede wan bovenstaande conclusies van toepasang op de mogelijke invloed van de werkhervattingsprognose op het al dan niet largdurlg arbeldsongesohiktbl1 Iven.

De door de betrokkene zelf geschatte kans op werkhervatting, welke bly fongeren met relatier welnig last en het gevoel meer gezond dan zlek te zljn het groatst is, oefent b1j de totale groep werkhervatters en bl1juers 
wel een grote rechtstreekse linvloed ult op de latere werkhervatt 1 gg: een grote geschatte kans leldt vaker tot rejle werkhervatting. B1J de gematchte groep wordt deze invloed echter verkiaar door de zlekteprognose en het gezondheldsoordeel.

D1t cluster van onderlinge samenhangen kan als volgt in schema worden gebracht.

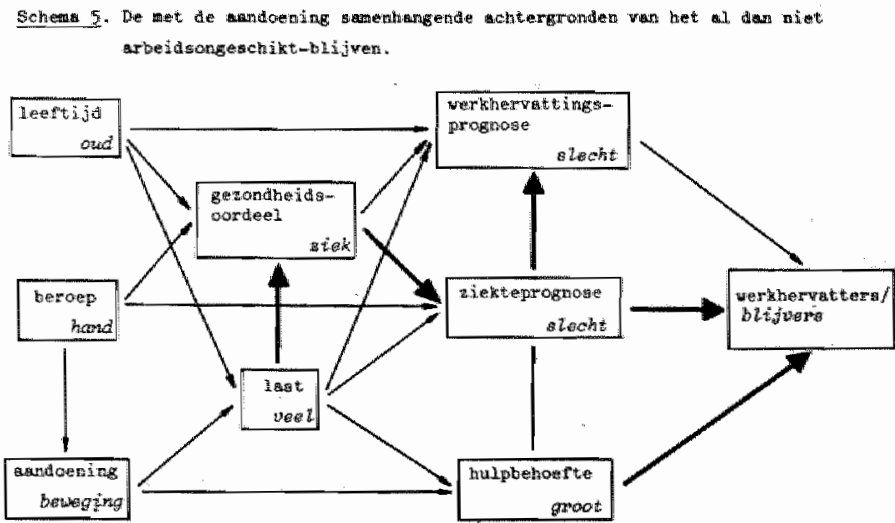

De dikke lijnen geven de belangrijkste relaties tussen de genoemde varlabelen aan zoals die ult de regresileanalyses voor de totale èn de gematchte groep werkhervatters en bl1 jvers naar voren komen.

De dunne $11 \mathrm{jm}$ voor de invloed van de werkhervattingsprognose op de reele werkhervatting duldt op het relt dat deze invioed aanwezlg geacht kan worden, al komt hid alleen b1j de totale groep naar voren.

De 1 nvloed van de zlektevarlabelen op het langdurlg arbeldsongeschikt-blifven ligt voor de hand: deze varlabeien weersplegelen de reele (on)mogelijkheld tot werkhervatten. De invloed van de werkhervatingsprognose op het arbeidsongeschlkt-blijven is echter niet zo vanzelf sprekend. Verklaringen in termen wan de ernat van de 
zlekte, leeft1ja, beroep en andere gemeten variabelen gan 1 miner niet op.

Men veronderstelt wel dut de houding en het gedrag wan de arbelasongeschikte, woor zover die voortvloelen ult zidn schatting wan ziln werkherwatingskansen van belang z1ln: schat h1j die gerlng, dan kan dat consequentles hebben woor de mate warin hil zich neerlegt b1j het arbeldsongesch1kt-zijn en de mate warrin hil pogingen zal ondernemen om weer an de slag te komen. Belde att1tudes zouder kunnen bljdragen tot de indruk die de versch1liende functionarissen van het $G A K$, het $S F B$, de GMD en het $G A B$, belast met de "reintegratie" van de arbeldsongeschikte, wan zijn arbeldsmotivatie krijgen. Is die Indruk gunstiger, dan zouden zij hun bemlddelingspogingen wellicht met meer elan ultvoeren, dan wanneer zil de arbeldsongeschikte "weerstrevend" (een GMD-u1tdrukk1ng; Weljel en Costenbrink 1970) vinden.

Deze redenatie wordt, althams wat betreft het eerste deel - werkhervattingsprognose * berusting en werk-zoekgedrag - ook door Van Wezel gehanteerd, wanneer hij in zin onderzoek naar de herintreding van werklozen in het arbeldsproces, constateert dat de persoonll jke schatting van de kansen op herintrede een zeer belangrijke invloed op het feltelijk al dan niet herintreden heeft (Van Wezel 1970, pag. 107).

Desondanks kan betreffende arbeldsongeschikten niet met zekerhe1d gezega worden dat bovengenoemde redenering julst 1s, hoe plauslbel het een en ander ook moge 11 Jken.

Tot een dergelijke conclusie komt men bij nadere beachowing van de relatie tussen de alternatieve arbeldsoridntatie en het al dan niet werkhervatten. Deze relitie werd $b 1 j$ de gematchte groep werkhervatters en bliyvers (N 132$)$ wel vastgesteld, bij de totale groep $(N=219)$ enter niet. Het versohil wordt veroorzalut door het verschll in de oe-orde correlaties van de ar- 
beldsopientatle met de werkhervatting; tussen de duverse onderluge samenhangen van deze met andere variabelen werden in de regresile-analyses geen verschilien geconstateerd. Waarschijnlljk ligt an het correlatieverschil de mate van kromlijnighe1d van het verband ten grondsiag. 3)

Gezien het betoog op pag. 124 kan gesteld worden dat een rechtstreekse invloed van een alternatleve arbeldsorientatie op het arbeldsongeschikt-bildven warachljnlidk, mar niet voliedig zeker 1s. Bijft echter de wrag wat de achtergrond zou kunnen aljn var het (eventuele) feit dat een nlet-alternatlewe arbeldsortentatie - arwijglng van de ultspraken "er zljn eer hoop dingen die je beter kunt doen dan werken" en "Ledereen moest kumen kiezen of hij w1 werken of niet" - na 4 maanden arbeldsongeschlkt-zijn weel vaker voorkamt b1j toekomstige werkherwatters dan bij blijvers.

Het is mogelijk dat hiervoor dezelfde redenatie opgat als ten aanzlen van de invloed van de werkhervattingsprognose: als men werken boven andere activiteiten stelt zal men wellicht meer pogingen ondernemen om weer aan de slag te komen en neer effectleve medewerking krygen van de diverse arbeidsbemidalaars.

ook nu bledt het onderzoekmaterial echter geen bewijs vaor de Julstheid van deze veronderstelling.

Weliswar blljken er zowel ult de totale als ult de gematchte groep verschilien tussen de werkhervatters en de langaulg arbeldsongeschikten wat betreft de angevingsvariabelen, doch dat impliceert niet dat deze verschilien voor de hand liggen.

Na 4 maarden arbeldsongeschikt-zijn blijken veel sockalie contacten, met name met de famille, en een negatief cordeel over de amgeving - onvriendel1 Jk, niet meelevend, veelelsend, onverschill1g eto. - veel vaker wor te komen bly degenen die langdurlg arbeldsongeschikt zullen blijwen, terwli (relatief) welnig contacten en 
een positlef oordeel ower de omgeving vaker bly de werkhervatters voorkomen. Deze verbanden blijken overigens pas als wekenlng gehouden wordt met de samenhangen van andere varlabelen met zowel de contacten en de omgevingsevaluatie als het al dan niet werkherwaten.

omtrent de verklarlng wan de invloed wan de omgevingsevaluatie op de werkhervatting kan men slechts speculeren. Wellicht bangt het fe1t dat men de omgev1ng als vijandig, onvriendelijk etc. beschowmt samen met cen gebrek aan solale vaardigheden; een gebrek dat tevens een belemering vormt voor het hervatten wan het werk. ook de achtergronden van de Invlaed van de hoeveelheld contacten op het arbeldsongeschikt-biljven zijn ondulde11Jk. Mogelijk is dat mensen met intensieve famillerelatles minder behoefte hebien can contact met de maatschapply buiten de Intieme sfeer, wardoor zid minder pogingen tot werkervatting zouden kunnen ondernemen.

Hoewel en hoge contactrequertie en een negatieve evaluatle van de omgeving onafhankelijk van elkaar het arbeldsongeschikt-blijven belnwloeden is hun comblnatie zeer opvallend, dar over het algemeen veel contacten samengaan met een positlef oordeel over de amgeving. D1t houdt in dat arbeldsongeschikten die na 4 maanden een hoge contactifequentle aan en negatieve omgevingsevaluatle paren, wel zeer warschijnlijk tot de langdurig arbeldsongeschlkten zulien (gaan) behoren.

op grond darvan zou men kunnen veronderstellen dat de langdurlig arbeldsongeschikten een bestaan leiden dat wioh voornamellak binnen het gezin en de familie af speelt, en dat derhalve in matschappellyk opzlcht als belsoleerd of teruggetrokken getypeerd kan worden. De camlilekrlng 1 als een soort bastion, warbininen men zlch prettig en vellig voelt en warbulten zloh de enigsins vilandige bultenwerela bevindt.

Een dergelifke typering van de langdurlg arbeldsongeschikter slut a an (en dat ls van belang lndien men $21 \mathrm{ch}$ realisert dat onder hen de (oudere) handarbelders over- 
vertegenwoordigd zign bij de literatuut over de matschappelijke positie van de arbelders en de "blue collar world" (Shostak en Gomberg 1965, Nijhor 1977).

ook het feit dat arbeidsongeschikten als. kwetsbare en minder weerbare groepen $1 \mathrm{n}$ de samenlewing worden beschouwd (Wiersma 1979, ormel 1980) is compatibel met een Karakterisering van de driemal geinterviewden als matschappel1jk teruggetrokkenen.

\subsection{Samenvatting}

Langdurlg arbeidsongeschikten blifken in een betrehkelijk vroeg stadium van het arbeldsongeschikt-zijn te herkennen, dat wil zegren in een aantal opzichten duldelijk te verschillen van (relatief) kort arbeldsongeschikten.

Na vier maenden niet meer werken onderschelden degener die noz een jaa arbeldsongeschikt zullen blijven zich van degenen die binnen een half Jaa weer aan het werk zulien gaan in objectieve èn subjectieve kenmerken. objectieve kenmerken zijn leeftija, beroep en ard war de aandoenlng. Van de respondenter, dle allen aan bet onderzoek deelnamen op grond wan de verwachte 1angdurigheld van hun arbeldsongeschikt-zijn (tot minstens het 16-maands interview) blijken de blijvers ouder, vaker (ongeschoolde) hanarbeiders en vaker 11 ddend aan bewegingsaandoenlngen dan de werkhervaters.

Deze kenmerken blifken bun invioed op het langdurifg arbeldsongeschikt-bllJven te doen gelden via een a antal. meer subjectieve factoren.

Ma 4 maanden arbeldsongeschlkt-zijn kunnen de langdurdg arbeldsongeschikt-blijvenden van de latere werkherktters in de eerste plats onderschelden worden op grond van hun grotere behoefte a an hulp (veroorzakt door hun bewegingsaandoeningen) er een minder grote kans op herstel (waaraan hun ongeschoolde handarbela by jaragt). 
ook hebben oe langdur $1 \mathrm{~g}$ arbeldsongeschikten een pessiwitischer k1Jk op hun werkhervattingskansen (vooral op grond van hun hogere leeftidd).

In de derde plaats blijken de blljvers meer contactem met famlieleden te hebben en de wereld daarbulten als onvrlendel1 jker en vijandiger te beschowen dan de werkhervatior:

Een latste kenmerk, dat de bl1 jvers van de werkhervatter zou kunnen onderschelden is hun alternatievere arbelidorientatie. De ultigevoerde analyses geven echter geen zekerheld omtrent het belang van deze k1jk op werken voor het arbeldsongeschikt-bl1jven.

De verklaring van de invloed van de subjectieve zlekte-ernst op het al dan nlet werkhervatten $11 \mathrm{gt}$ voor de hand: deze 1nwloed wordt in belangriyke mate bepaald door de reele mogeliskheld om met een handlcap weer aan de slag te komen.

De verklaring van de linwloed van de andere onafhanke11jke varlabelen kan echter niet gezocht worden in obJectieve werkhervattingsmogelijkheden. Mogelijk spelen hierblj de houding ran de betrokkene ten opzichte wan werken en niet-merken, zijn activiteiten tot werkhervatting en zifn soclale vardigheden een rol.

Het belang van de zlektevarlabelen (zlekteprognose en hulpbehoefte) bl1ykt ongeveer even groot als dat van de omgevingswarlabelen, de werkhervattingsprognose en wellicht de arbeldsorlentatie.

U1t het onderzoek van wiersma (1979), dle onder meer de achtergronden van de latere who toetreding onderzocht na 4 makrien arbeldsongeschiktheld, blijkt de herstel(miekte)prognose echter de belangrijkste voorspeller van de toetreding tot de WAO. Deze resultaten zijn echter niet geheel vergelljkbarr, wooral doordat in Wiersma 's onderzoek èn de operationalisatie van de zlekteprognose èn de inhoud van de overtge bestudeerde varabelen stert verschllien van de hler gebrulkte variabeler. 


\section{Noten bij hoordstuk 6}

1. Belde groepen maken deel ult ran groep $A$, die bly 4 maanden tevens 42 arbelisongeschikten bevatte die $2 x$ geinterviewd zouden worden en 45 , die om andere redenen dan werkhervatting na $1 \times$ ultvielen. Alles bij elkar bestond sroep $\mathrm{A}_{4}$ dus ult 306 personen (schema 1 , pag. 44). Van bovengenoemde 45 personen is niet bekend of al binnen een half jaar weer aan het werk zijn gegaan. Uit deze getallen kan derhalve geen exact percentage WAO-toetreders afgeleld worden. Alleen 1 s wel duldel1 $1 \mathrm{k}$ dat het aantal. WAO-toetreders minimaal 24 van het aantal 4 -maandsgevallen bedraagt $(74: 306)$.

2. Leeftyd, beroep en aandoening vormden ieder als dichotomie de basis warop de matchlng van werkhervatters en blijwers geschiedde. Leeftijd en beroep zijn desondanks bij deze regressie-analyses als ordinale variabelen ingevoerd, om ledere invloed wan leeftijd en beroep volledig te kumnen verrekenen.

3. Eij Inspectle van de kruistabellen woor de gematchte en de totale groepen blijkt namelijh dat relatief veel werkhervatters zowel woorkomen bij een extreem alternatieve arbeldsorientatie - "er zijn een hoop dingen die je beter kunt doen dan werken" en "elgenlijk moest ledereen kunnen klezen of je wllt werken of niet " als bij een extreem niet-alternatieve oriêntatie. Daarbinnen, dat wil zeggen van alternatlef naar niet alternatief komen respectleve$11 \mathrm{Jk}$ minder en meer werkhervatters woor.

zo wordt het globale verband tussen niet-alternatieve arbeldsorlentatie en werkhervatuting "wertsoord" door het felt dat ook de extreen alternatieve orlentatie veel werkhervatters oplevert. Deze verstorlng nu $1 \mathrm{~s}$ het sterkst bis de totalle groepen ( $N=145$ en 74 ) zodat daar de correlatie wussen arbejdorlentatie en werkhervatting "igedrukt" wordt.

4. Die onderdrukkende variabelen zijn blj de gematchte en de tatale groep niet dezelfde. De invloed van de contacten wardt onderdrukt door de evaluatle van de omgev1ng of de 
zlekteprognose an de alternatieve arbidsoridntite; de Invloed var de omgevingevaluatle wordt onderarukt door de contacten of het gezondheldsoordeel en de afeer in het $\sin 1 \mathrm{in}$. 
HOOFDSTUK 7

SAMENWATYING EN BESPREKING VAN DE ONDERZOERUITKOMSTEN

\subsection{Samenvatting van de uitkomsten}

In deze paragraaf zullen de essenties van de hoofastukken 4,5 en 6 de revue passeren.

HOOFDSTUK 4

Allereerst werd vastgesteld dat de twee aspecten van de beleving van het leven zonder werk een verschiliend licht werpen op het algehele belevingsniveau. De satisfactle met het dagelijks bestaan blijkt overwegend negatief: rulm $90 \%$ van de respondenten wil llerst zo snel mogel1jk weer aan het werk, drdekwart van hen bevalt het nu niet best, voor ruim 60\% overwegen de vervelende dingen van het arbeldsongeschikt-zijn boven de prettige dingen en rulm de helft vindt nlet dat men nu elndelijk kan doen waar noolt thd voor was. Alles bij elkar betekent dit dat rond de helft der respondenten op leder moment - na 4, 10 en 16 maanden arbeldsongeschikt-21yn op minstens drle van de vier genoemde ultspraken reageert met de meest negatleve antwoordcategorie. Slechts 2 tot 4 van de respondenten beantwoorat drie of vier uitspraken in positieve zin.

De belangrijkste als onplezierig ervaren aspecten van het arbeldsongeschilut-zijn waren: de aandoenling, het niet-werken, het thuis zitten met zijn verveling en nutteloosheld, het gevoel nergens meer b1s te horen, de onzekerheld over de toekomis en de financlele achterultgang. Als prettige dingen werden genoemd de grotere hoeveelheid vrije tijd, het intensiever contact met het gezin en de grotere vrijheld.

De algemene levenshouding 15 duldelijk veel positle- 
ver dan de satisfacte: rulm de helft der respondenten heet het nlet zo war te verauren, vindt het leven niet zo biecht, zlet de toekomit niet somber in en vragt ach noolt af waarwoor je leeft. Slechts 8 wan hen beantwoorade alle ultapraken 1 in negatleve zin.

Het versen1l tussen de satisfactle en de levenshouding kan wellicht enerzljds verklazd worden ult het grote aanpassingsvernogen dat de mens bezlt. Anderzijds 1 s het mogel1Jk dat men de algemene moelte met het leven minder makkel1jk toegeeft dan concrete praktische 1rritat1es.

We de wastatelling dat de concrete vergelijking van het arbeldsongeschikt-zi in met de wroegere levensomstandigheden - de satisfactie - meestal negatief uitvalt voor het arbeldsongeschikt-zijn, doch dat dit lang niet altigd tot een sombere levenshouding leldt, ging het in dit hoofdstuk om de vraag warabor de beleving, en de verschillen daarin tussen de respondenten, belnvioed wordt.

Het antwoord luldt in de eerste plats dat leeftijd, beroep en andoenting nauwelljks invioed op de beleving Ut toefienen.

In de tweede plats blifken de achtergronden van de satisfactle met het dagelijks bestaan over het algemeen te verschlilen van de achtergronden van de algemene levenshouding. Overeenkomsten tussen belde komen echter ook voor.

D1t betekent dat de achtergronden vam de beleving van het arbeldsloos bestaan in grote 11 ynen als volgt geachetist kunnen worden.

De t1jdsbesteding 19 de belangrijkste determinant van de beleving. Haar bljarage aan de satisfacte van het dagelidks bestaan en aan de algemene levenshouding is wellswar nlet de grootste die an belde dimensles geleverd kan worden, doch het felt dat de tijasbesteding bif belde dimensies een sterke tweede plaats inneemt, zargt 
ervoor dat zlj alles blj elkaride meeste lnvloed op de beleving van het leven zonder werk ultoefent. 1)

Derhalye: het leven zonder werk is beter ult te houden naarmate men zlch minoer verveelt, de dagen snel windt gaan en het gevoel heeft 1 tets gedaan te hebben en naarmate men de bezigheden plezleriger, belangrijker, waardevoller en nuttiger windt.

Aangezien de mate van verveling var alle tudsbestedingsvariabelen de sterkste bijarage an de satisfactie levert en een grote meerderheld van de onderzochten zich regelmatis verveelt (hoogstens $10 \%$ van de durgroepen verveelt zich noolt) is het begrijpel1jk dat de beleving van het arbeidsloos bestaan overwegend negatief uitwalt. De concrete bezlgheden dragen zelf vrljwel noolt rechtstreeks bij tot de beleving van het arbeldsioos bestaan, maar zij dragen wel bil tot (het verdriyen van) de verveling en (het verminderen vam) het "nutteloze aanrome1en".

Het gevoel overal bulten te staan is de tweede ${ }^{1}$ determinamt van de beleving van het leven zonder werk. De algemene levenshouding wordt in de eerste plaats door ait gewol bepald; voor de satisfactle met het dagelijhs bestan 1 s de ervaren sociale lsolatie lets minder belangrigh.

Hoewel de ervaren soclale Lsolatie in eerste instantie is gehanteer als indicator vaor de relatie van de arbeidsongeschikte met zijn omgeving, lijkt hij dat bij nader inzlen niet te $z 1 \mathrm{Jn}$. Waarschijnjljk weerspiegelt het gevoel oweral buten te stan diens interpretatio van niet-werken en het zlek/gehandicapt zijn als abriormal: ongewoon en ongewenst.

Rulm eenderde van de respondenten kent het gevoed overal bulter te staan niet, betgeen mede verklart wasidoor de algemene levenshouding overwegend niet zo somber 1 s.

De waarderlng van het yroegere werk en de visle op werken in het algemeen women de derde achtergrand, waruit de beleving van het niet-werken door arbeldson- 
Geackikten voortkomt. Deze ultspraak alent echter gespeolficeerd te worden voor de belde belevingsilmensies, daar z1j in deze formulering voor geen van beide afzonder 11Jk opgat.

De satiafactle met het dagelijks bestar word in zeer sterke mate door de visle op (het) werk(en) bepald; zelfs in de eerste plaats door de mate warain men het wroegere werk mist, het belangrijk wond en er tewreden mee was. 0ok de mening dat wemen niet méer 1 s dan een noodzakelijk middel tot geld verdienen of dat werken én van de vele mogelijke bezigheden ale naar keuze al dan nlet vercloht zou moeten kunnen worden, dragen bif tot de (postleve) satisfactle met het leven zonder werk. De overwegend negatieve satisfactie kan derhalve grotendeels verklaard worden door de owerwegend grote werkwaardering (drlekwart wan de ondervraagden mist het werk, was er zeer tevreden mee cn vindt werken belangrljk) en de overwegend nlet erg alternatieve of instrumentele arbeldsorientatie.

De algemene lewenshouding ontstat echter (vr1jwel) geheel los van de werkwaardering en de arbeldsorlentatie.

Naast deze drle belangrijke achtergronden wan de beleving van het leven zonder werk nemen het gezin, de (ernst van de) zlekte en de geschatte werkhervattingskans een ondergeschlkte positie 1s. Toch is hun bijdrage aan de beleving, wooral aan de algemene levenshouding, echter niet te verwarlozen. Een sombere levensvisle blilkt lmmers mede gebaseerd op het gevol meer zlek dan Bezond te z1jm, op een gerling geachte kans op werkherwatting, op de merkbare gevolgen van de dallng van het gezlnsinkomen en op een relatief sllechte sfeer im het gea $1 \mathrm{n}$ :

Dat de algemene levenshouding mestal nlet al te somber 1. komt mede doorat zojulst genoemde oormaken van somberbeld lang nlet bij alle respondenten anwezg wh. 
Samenvatiend kan worden gestedd dat de overeenkomst tussen de satisfactie wan het dageligks bestaan en de algemene levenshouding bestaat in het felt dat belde de beleving weersplegelen van het leven monder werk als atwijking van het gewone en wenselilke leven met werk. Die belewing van de arbeisongeschiktheld heert echter twee duldeiljk verschillende acoenten. De satisfactie geeft vooral ultarkking aan de uitkoms van de vergelijking van het heden met het verleden, warbid de betekents van werken, bet gemis van werken in het algemeen en het elgen werk in het bijzonder essentleel zijn.

De algemene levenshouding echter dulat meer op de erwaring van de huldige, en zelfs enlger mate van de toem komstige levensomstandigheden.

zoals reeds vermela steekt het concrete heden negatiaf af tegen het verleden. Over het leven en de toekoms in het algemeen is men echter gematigd positief.

HOOFDSUK 5

In dit hoofdstuk worden de eerste resultaten besproken var het longltudinale onderzoekgedeelte, betreking reboend op de 74 ariemal geinterviende arbeldsongeschikten.

Voor de meesten van hen is het leven zonder werk in de loop der maanden onderhevig aan vele veranderlngen, die dan weer als gunstige en dan weer als ongunstige ontwikkelingen in de situatie kunnen worden opgevat.

Bij de meeste variabelen houden dere elkat in everwioht, bij een zevental is er echter duldejljk aprake van overwegend negatleve veranderingen.

Men krijgt over het algemeen meer last van do wekte, de kans op werkhervating wordt minder geant, de arbeldsorlentatie wordt minder instrumenteel, soclale contacten worden minder, de alversiteit aan bezigheden wordt groter, de sfeer in het gezin wordt alechter en de gevolgen van de inkomensdaling worden merkbarader. 
Ondank deze onplezlerige veranderingen verschult de watractie met het dagellyks bestaan in overwegend positleve wchting. Deze tegenstelling blijkt verklara te worden door het felt dat de atsiactieveranderingen alch geheel 100 van de over 1 ge veranderinger van 4 tot 16. manden arbelasongeschikt-z1 In voltrekken.

De veranderlngen in de beleving blljken samen te hangen met de ultgangableving na 4 manden: een positief begin levert negatleve veranderingen op en een negatief begin makt positleve veranderlngen mogelljk. Deze regressie naar het gemiddelde werklaart de elkar in evenwicht houdende veranderingen in de levenshouding wel, matr de overwegend positleve ontwkelingen in de satisfactie niet helemal: er is een positieve tendens voor een meederheld van de respondenter ongeacht de beginsatisfactie.

Ter verklarding varn dece tendens kan welilicht gedacht worden a gewenning aar en a anvaarding van het arbeldsongeschikt-z1jn, walrdoor de dagel1jkse gang van zaken In de loop der manden lets minder schrijnend wordt.

In dit hoofdstuk komt tevens de vraag aan de orde in hoeverre de beleving ma 16 maanden geworteld 1 s in de ervaringen na 4 makiden.

De ulteindelijke satisfactie met het dagelijks bestaan blijkt grotendeels peeds in een vroeg stadium van het arbeldsongesch1kt-zIJn te worden gevormd: de doon de 4maandsituatle verklaerde variantie van de elndsatisfactle bedraagt $66 \%$, en dat 1 s meer dan de door de ge11Jkt1jdige erwaringen verklama varlantle. Met name een postlieve satisfatie na 4 mander, een gerirge mate van ulthulzigheld en een altermatieve kijk op arbeld op datzelfde moment voorspelien een positieve satisfactie na 16 manden.

De ulteindelifke levenshouding wordt wellswar ook voor een slgnifloant deel door de 4-mandssituatie bepaala (42\% verklaarde varlantle), maar toch minder dan door de ervaringen na 16 matanden. Bovendlen $21 \mathrm{jm}$ er 1 het begin 
wan het arbeldsongeschilt-2ifn geen yariabelen aan to wilzen die onafhankel1Jk van de anderen de ultelndelijke levenshouding voorspelien.

HOOFDSTUK 6

In hoofdstuk 6. is vatgesteld dat na 4 manden arbeldsomgeschikt-zijn de latere drlemal gelnterviewden (de langaurig arbeldsongeschikten) te ondersohelden zijn van degenen die binnen eer half Jar weer aan het werk gaan (ae kort arbeldsongeschikten).

Als objectleve verschllien vielen allereerst leeftijd, beroep en aandoening op: de blijvers zijn ouder, vaker (ongeschoolde) handarbeiders en lets waker lijdend an bewegimgsaandoeningen dan de werkhervater.

Dere verschlilen komen woort ult de meer subjectieve verschillen tussen werkhervatters en blijvers, warvan allereerst de ervaren zlekte-ernst genoend moet worden: de latere langdurig arbeldsongeschikten hebben naar hun mening meer behoefte aan hulp en minder kans op herstel dan de latere werkhervaters.

Bovendien achten de blijvers hun kans op werkhervatting klelner dan de werkhervatters.

Moet bij de zlekte-ernst de verklarling van haar 1 hvloed op het al dan niet werkhervatien vooral gezocht worden in de reele (on) mogelijkheld om met een zlekte/ handlcap werk te vinden, biy de inwloed van de werkhervattingsprognose is dat niet het geval. Welilcht moet in dat verband gedacht worden aan de noudimg ten opzlohte

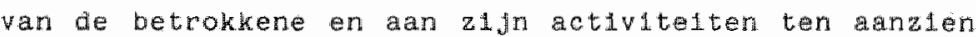
van werkhervatting. Zo zou gewenning a an en anvaraling van het nlet-werken de latere driemaj geintorviewder kenmerken, terw1jl de latere werkhervaters yulst het werken als te verkiezen mogelijkheld zouden zien en die actief pogen te reajseren. Een acanwling voor de platusiblitelt van deze redenate le $1 \mathrm{gt}$ in het felt dat de werkhervatters warschijndjk een milder alternatiewe 
arbiedsorlentatie hebben dan de blijwers.

ook is de twee omgevingswablaben die de langarig arbeldsongeschikten na 4 maanden arbeidsongeschikt-zijn van ab latere werkervatters onderscheiden, hun relatief grote antal contacten met famileleden en hun negatieve oordeel over de omgeving, is het mechamisme van de invioed niet drect duldelijk. Mogelijk speelt ook hierblj de houding tegenover werken een rol, evenals wellicht een gebrek aan soclale varalgheden om zich bulten de fam1lesfeer een bevredigende plaats in de matishapplj te verwerven.

De beschikbare gegevens laten zyen dat ernst wan de zlekte ongeveer even belangrijk is woor het al dan niet langduris arbeldsongeschikt-bilfwer als ae op arbeid gerichte en omgevingsgebonden ractoren.

7.2. De beteken1s van de verschlliende facetten van het leven zonder werk

Het onderzoek heeft nast de kwantitatieve gegevens die leldden tot bovenstaande ultkomsten ook informatie opgeleverd de ofwel kwalltatlef van aard was, ofwel kwant1tatief, maar nlet geschlkt voor ultgebrelde analyse $($ par. 3.7).

Deze informatie werpt ilcht op de betekenissen van de verscheldene facetten wan het leven zonder werk van arbeldsongeschikten en bledt daardoor extra inzicht in de reed vermelde onderzoekresult ten.

In deze paragraaf (een gewijzigde versie van het MIPGelndverslag) zal de ult de interwlews verkregen informatie, aangevuld met enlge 11teratur, worden besproken. 
DE SOCIALE WUNCTIE VAN HET EIGEN WERK EN WERKEN IN HET ALGEMEEN

Allereerst verdient de werkwardering, als belangrljkste achtergrond voor de satisfacte met het dageIIjks bestaan, nadere beschouwing.

De werkwaardering is opgebouwd ut de subvaribelen werkgemis, het belang van werken, tevredenhe1d met; plezier in en tegenzin tegen het werk, warvan het werkgemis de sterkste invioed op de satisfactie heeft. Wat dit gemis inhoudt blijkt ult de antwoorden op de betrefiende vraag: men mist wooral het sociale aspect van het werk, de sfeer en de contactem, het volwardig meedoen in de matschappij, het erbij horen, maar ook het nuttig $21 \mathrm{jn}$ er de normale regelmat. Allemal zaken die niet ultslultend betrekking hebben op het specifiek elgen werk, maar ook op de functies van werken 1 n het algemeen. Dat het gemis daarvan in zo sterke mate de sat1sfactie met het leven zonder werk bepaalt, impliceert dit in dat leven onvoldoende compensatie voor die werkfunothes te vinden is.

In de soclalle behoeften van de mens - contact, erkenning en wardering - kan kenmelijk wrijwel ultsluitend door (betalide) arbeid worden voorzlen. Men kan hierult aflelden dat de contacten met famlie, vrlenden en kennlssen, al zijn die viak na het ophouden met werken vaak frequenter dan daavoor, geen alternatlef zilin voor de werkcontacter. Dit is niet onbegrijpelijk gezien de andere aard erwan. Bij werkcontacten speelt immers de wararding voor de nuttlge bijarage een rol. Het gevol van nuttigheid, waardevolie prestatle on het functionele "erbly horen", zljn wezenlifk anders dun de gezelligheld en de emotionele samiorigheld die famille en vrienden bleden.

Bovendien legt het werk, nlet alleen doón de contacten, maar ook door de matschappellyke betekenis ervan, eer relatie met een veel groter deel van de helo matsohap- 
11, dari de contacten wet en meestal niet grote groep intion.

Voor het gevoel van elgenwarde blifkt dat grotere matBchappel1Jke berelk a1kij1s van groot belang.

kwant (1977) merkt in dit verband op dat naarmate de samenleving meer als arbeldsbestel sing functioneren de socila collen buten de micro-sfeer van het geain oteeds meer binnen het arbeldsbestel, de macro-sfeer, vervuld werden. De rollen in de meso-sfeer, tussen het gezin en de "grote" maatschapplj in, werden daarentegen schaarger. Met het wegvallen van de arbeldarol, de soclale macro-rol bij uitstek, vervalt dan vrlywel ledere mogelifkheld een matschappelifke rol te vervullen: in de butrt en de famile, in de "klelne" matsichapply heeft lang niet ledereen een duldelijke functle, en zo hil die al wej heeft dan wordt die in aanzlen, nut en belang toch veelal minder geacht dan de functie in het arbeldsbestel.

De voor velen anvervangbare matschappelijke functle van werken blifkt nlet alleen ult de lnvloed wan het werkgemis op de satisfactle met het lewen zonder werk, maar komt ook en zelf"s blj ulwstek tot ultdrukking in net gevoel overal. buiten te staan, ultgerangeerd te zijn en niet meer bij te horen. Dit gevoel kwam in de interviews vak spontaan aan de orde naar anlelding van de open vragen naar de verwelende dingen, het werkgemis en de veranderingen in het leven zonder werk wan de laatste zes maanden. Werd de ultspraak "als je niet, meer werkt sta je elgenlijk overal bulten expllelet aan de respondenten voorgelegd, dan bleek rulm de helft van hen ermee in te stemmen. 40 was het dan echter niet mee ens.

Het felt dat het 1solatiegevol niet voortikomt ult een gebrek aan contacten of ult onplezlerige contacten met de omgeving. marr lit de door het niet-werken en de zlekte als veranderd ervaren relatie met de matschapply en vooral het felt dat daarbig de evaluatie van de 
tijasbesteding een belangrijk criterlum ls, leldt tot de noodzaak enlge aandacht te schenken an de samerinang tussen de soclale betekenls van werken, har betekents als tijdsbesteding en de tijdsbesteding van arbeldsongesenikten.

WERKEN ALS TIJDSBESTEDING EN DE TIJDSBESTEDING ZONDER WERT

Werken bepalt in hoge mate de structur en de regelmat van het leven: de dagindeling, maa ook de cyclus van werkdagen en weekenden, van feestagen en vakantles worden doom het werken bepaald $c . q$. krljgen door de afwisseling van werken en vrije tijd hun betekents (Henry o.c.).

Door het wegvalien van het werken wordt die vertrouwde regelmat opgeheven: $e^{3}$ is geen werktijd en geen vilje tijd meer, er is alleen maar (een zee van) t1ja.

Hoe belangrijk het 1 s om de tijd te structureren blifkt nlet alleen ult het felt dat het gemis van de regelmat van het werkzame leven in de interviews herhaaldelijk spontaan aan de orde kwam, maar ook ult de verveling, waardoor vele arbeldsongeschikten worden geplaagd. Verveling komt lmmers niet alleen voort ult niets doen, maar ook ult "ongeorganiseerd aanrommelen".

Kennelijk is men over het algemeen niet in staat om enlge $11 \mathrm{Jn}$. in het leven zonder werk aan te brengen, hoezeer men zlch soms ook vastklampt aan de vaste tijden en rituelen van silepen, opstaan, eten, koffie drinken on det $\mathrm{gel}$ ilje.

D1t onderscheld in structur en regelmat tussen het arbeldsleven en het leven zonder werk 1 is 1 termen wan sociologische roltheorie te vertalen als het onderscheld tussen positie-en situatierollen.

Kenmerk voor een postiterol $1 \mathrm{~s}$ dat er vil algemeen aanvaarde normen en verwachtungen bestaan omtrent het gedrag, dat lemand in de desbetreffende positie, dat wit 
zegsen de plata in een min of meer hierarchisch geordende structur van vele posities, mot en zal vertonen (Var Doom en Lammers 1964, Gerhardt 1971). Het handelen van werknemer $x$ in bedrigf of lnsteliling y Iigt min of meer wast, voor hem en voor degenen met wle hij in die hoedanigheid te maken heeft. Niet alleen stat vast hoe lat hij op z"n werk alient te versch1Jnen (en hoe laat hil dus op moet staan), maar ook waar h1j heen gaat, met we hil wat doet, hoe laat h1 I luncht e.d.

Poslteroller bepalen het ritme van het dagelliks leven. Een situatierol betreft de normen die geiden in een concrete stuatie die een beperkt tldabeslag met zich meebrengt. Soms $z 1$ In de vigerende normen vrij precles (bijwoorbeeld verkeergdeelname), soms zijn zlj weinig strikt en van het individu afhankelifk (hobby's bijvoorbeeld). Bovendien bestaat er meestal een grote vrigheld atuatles wel of nlet binnen te treden. Gerhardt (1971) spreekt over de situatie als een veel minder structureel. bepaalde handelingscontext dan de positile.

Mensen die een arbeldsioos bestaan leiden, hebben zich als regel geen nleuwe positierol verworwen. Van arbelder zidn z1J nog geen "vrlje tijder" geworden (Philipsen 1974). De vriJgekomen tijd wordt doorgebracht alsof men in een opeenvolging van sltuatlerolien terecht is gekomen.

Bif het wegvalien van de arbeldsrol blifkt de vrijheld van handelen, het gebrek aan verplichtingen, hoewej vaak gewarcieerd toch dikwly s een leegte in te houden. De atuatierollen blijken alechts een complement van en seen alternatier voor de posttierol te kunnen vormen. Dat geldt overigens nlet alleen de mate warin de verwathelingen omtrent het gedrag duldeiljk ziJn, de structuur en de regelmat van belde rollen, mar ook de nutswarde van de te vervulien bezigheden. Arbeldgongeachikter blijken Immers ook molte te hebben met het vinden van belangrijke, nuttlge en wardevolle activitelten. D1t wordt nlet zozeer veroorzaakt doomat de 
activitelten die men verricht niet nutts of wardevol zouden zlyn, mar vooral doordat nut en warde ongeveer synonlem geacht worden met de berigheld de de matschapply door middel van een geldelijke beloning als zodan1g honoreert: (betaalde) arbe1d. De werkzamheden die men als arbeldsongeschikte vericht worden nu eenmaal zelden betaald en lijken overigens in andere opzlchten ook nlet erg op arbeld; afgezlen van het eventwele nut $1 \mathrm{~s}$ ook in ander opzlcht de relatie met de maatschapply grotendeels arwezig.

De meeste arbeldsongeschikten houden zleh 1 mers vooral bezlg met het hulshouden, inclusief boodschappen, en daarnaast met tv kijken, radio lulsteren, wandelen, ommetjes maken en bezoek afleggen en ontvangen. De eerste drie wrijwel ledere das, de laatste en par keer per week. Aan het huishouden gaat men in de loop der* maanden over het algemeen méér tijd besteden; aan de bezoekjes minder. Zelf sport beoefenen, bloscoop-, schouwburg-, café-, tentoonstelling-en theaterbezoek en cursussen nemen of geen of weinlg tijd in besiag. De overtge t1jdsbestedingen z1jn woorname11jk "eohte" vrljet1jdsbestedingen (hobby's, klusjes, hulsideren etc.) die soms wel vaak platsuinden, mar niet veel t1ja kosten; afgewisseld met incidentele burenhulp, therapleën en een hoogst enkele keer verenigings-, pol1tieke of vakbondsactivitelten.

opmerkelljk is, dat het overgrote deel van alle activitelten gekenmerkt wordt door een grote mate van hulselijkheld; vrljwel alles speelt zich in of dichtolj hulg af. 2) Eveneens opmerikelijk is dat men voor de meeste bezlgheden geen spectale interesse, oplelding of varaalgheden hoeft te hebber. Het zijn woornamelijk bezigheden, warmee men letter $11 j k$ de tijd door-brengt. 3 )

Dat een aantal respondenten hiermee nog redelilk tevreden zegt te zijn komt wooral doordat ze tegelijkertijd veruchten dat "Je dan tenminste nog lets doet" en door- 
dat ze geen mogellykheden tot andersoortige activitelten meer zien: "wees mar terreden met wat je hebt".

Recapltulerend kan worden vatgesteld dat de norma11telt van werken en de abnormaltelt van het niet-werken veratrekkende gevolgen heeft. De beleving van het met-merken wordt imimers in zeer sterke mate bepald door het gemis van de functles die werken had: het verkrijgen van soclaal contact, maatschappelijke otatus en wardering, het structureren van het dagelijks leven en het besteder van de tidd op wardewalle en rutt1ge wijze. Functies, ale 1 het leven zonder werk door vrljwel geen enkele alternatieve activitelt weruld blifken te kunner worden.

In a1t licht bezien 1 s het niet verwonderlifk dat de Instrumentele en de alternatieve arbeldsorientatie niet door een meerderheld van de ondervraggde arbeldsongesahikten wordt onderschreven (gemideld $33 \%$ vindt werken een noodzakelijk kwad, $43 \%$ niet meer dan een manter om geld te verdienen; slechts $16 \%$ vindt dat je beter andere dingen kunt doen dan werken). Evenmin verwonderiljk is het dat belde oriantaties, met name de instrumentele, in de loop der maanden nog minder aanhang krijgen: men ontdekt in toenemende mate dat werken meer was dan alleen een bron van inkomstem.

Door hun gerlahtheld op de praktische betekenissen van werken $1 \mathrm{~s}$ ook de invloed van deze arbeldsorlentaties op de beleving van het leven zonder werk verklaard.

Des te opvaliender lifkt het lelt dat de meer trad1tionele arbelasoricitaties - de viale op arbeld als plicht en als centrale walude - geén sterke lnvloed op de beleving war het arbeldsongeschikt-zijn ultoefenen.

Er begtat wel een samenhang van deze aspecten van het arbeldsethos met de belewing $\left(0^{\circ}\right.$-orde correlaties), mar deze wordt overschaduwd door de Invloed van de alternateve on Instrumentele orlentate: de praktische beteke- 
nissen var werken blljken belangrljker dan de morele wanneer het gaat on de beleving van het nfet-werken.

Tot dusverre $21, k t$ het leven var arbeldsongeschikten gedomineerd door de betekenls van het miet-herken zoals de ontstaat door het ontbreken van alternatieven woor a verschillende functies van werken. wot op zekere hoogte is deze voorstelling van zaken julst: de cernst wan de) zlekte, het gezinsleven en de omgeving hebben minder invloed op de beleving van het leven zonder werk dan de warderlng van en visie op (het) werk(en). de tijabesteding en de ervaren sociale lsolatie.

DIt betekent echter niet at de zlekte, het gezinsleven en de (relatie met de) omgeving volistekt anbelangrijke faceten van het leven zonder werk zijn.

\section{DE ZIEKTE}

Wat de ziekte betreft staat wellswar vast dat niet alle arbeldsongeschikten zo ernstig zlek of gehandicapt ziln dat ze echt volledig niet in stat zijn tot het vernichten van enige arbeid ${ }^{4}$, maar tevens stat vast dat ze vrifwel allemal last van een aandoenlng onderwinden. Vooral pljn, niet lekker voelen, futloosheld en verrioelaheld komen veel wor. Slechts 3 tot $5 \%$ van de ondervraagden had nergens last van; de meeste arbeldsongeschikten voelen zlch dan ook meer zlek dan gezond. Dat dit een stempel op het leven drukt stalt vast; gezondheld 1 s in de westerse cultur een zeer hoog gewardeerd goed. (1\% vindt het onbelangrijk!) en antasting dararan tast het elgen menszijn aan. "Je voelt Je mar een halif mens" is een zeer wak u1tgesproken werzuchting, die nog meer Inhoud wijgt als men bezeft dat pljn en dergelifke niet aleen "zomaar" vervelend $1 \mathrm{~s}$, maar ook ae mogelijkheden tot verschlilende handelingen en bezigheden beperkt. De klacht "je kunt niet meer doen wat je wllt, je 
kunt niet wit de voeten" werd door vele respondenten geult.

DLe beperkende 1nvloed van de zlekte blijkt ook, hoewel minder aterk, ult het verband tussen de zlekte- en de t1jabbeteding: hoe meer plyn men heeft en hoe zleker men zich woelt des te meer activitelten men op een laag pitje zet en des te minder verschillende activitelten men ontploolt.

B1f somilige aandoeningen ziln de elgen bewegingsmoge11jkheden zo beperkt, dat hulp van derden noodzakel 1Jk 1 ( $16 \%$ van de ondervraagden was min of meer hulpbehoevend). De afhankeligkheld die dat met $z$ lch meebrengt 1. voor velen, hoewel nlet het ergste van het zlek-z1jn, zeer onplezlerig. Het gewoel wan elgenwarde kan een grote knauk krljgen als men dagelifks voor allerle1 elementalce vertichtingen hulp nodig heeft (zle ook Ludils Collette 0.c., chodof o.c.).

Alles bly elkaar vormden de hinderlijke gevolgen van de aandoening het meest genoemde antwoord op de vraag naar de vervelende alngen var het arbeldsongeschikt-zign (door rond de helft der respondenten, blj 4 manden letis meer, na 16 maanden lets minder).

Naat deze vooral dreote consequentles heef het zlek-ziln ook een meer indireate psychlsche component. Zo kan het bigvoorbeeld worden opgevat als straf, als onverklaarbaar wreed en meedogenloos lot, als verlies, beproeving of ultagling (S1ller 0.c., Lipowsk1 1970). Dergel1jke reacties op de amdoening kwamen voor bly de ondervaagde arblasongeschikten, echter niet frequent. Vaker bleek de ziekte te fungeren als een soort brandpunt van het jeven: alle energle en aandacht wordt aan de wekte en aan (pogingen tot) heristel gew1jd. De belangsteliting voor andere dingen, ook voor onderwerpen war men vós de zlekte hevig in gelnteresseerd was, verflawt. De wereld lijkt zich te hebben verenga tot de 
zleke met; zijn ziekte en zijn directe ongeving (V.d. Berg 1957, Bremer 1972), zo qeifs, dat soms van ernstige egooentrioltelt kan womden gesproken (L1powikl 1969). Alles wat hij niet leuk vindt, wordt aan de zlekte verweten, en alles wat wel leuk is, kan pas als de zlekte genezen 1s. Zo $1 \mathrm{~s}$ de aandoening ook het brandpunt wan de hoop "als 1 k eenmal beter ben, dan....."

Afgezlen van het felt of het beter worden tot de moge11 jkheden behoort (vaak is dat niet 20 ), is het de vraag of alle ellende dan geweken is. Wat betreft mogelidke werkhervatting blijkt het mar al te vaak 1 jdele hoop.

Dit alles geldt met name in het begin van het alekzijn, hoewel sommige mensen, vooral degenen die in de ziekte ook voordelen zien (S11ler o.c., Lipowsk1 1970), zich heel lang op de ziekte kunnen blifven conoentreren. Maar voor velen komt er toch een tlja, dat de aandoen1ng niet meer het aliles overheersende levenskenmerk $1 \mathrm{~s}$. Er kan (enig) herstel mebben plaatsgevonden men 1 s an de nieuwe levenssituatie gewend geraakt, berust erin of heeft haar aanvard (zie de 11teratuur op pag. 113). Hoe moeizaam dit naar de achtergrond schuiven van de zlekte (voor zover mogelijk) ook is, sommigen, zij het een minderheld, slagen enin: niet ledereen noemt 1 mmers het zlek-zijn bij de vervelende dingen, of noemt het niet als eerste. Bly de afweging tussen de zlekte of het niet-werken als grootste probleem stelt $50 \%$ van de respondenten de alekte bovenaan, en een derde vindt de zlekte en het niet-werken even erg. Slechts $16 \%$ vindt de zlekte dus minder belangrijk dan het niet $\rightarrow$ werken.

Ten aahien van de zlekte moet derhalve geconcludeerd worden dat dit allerminst een te verwarlozen facet van het arbeldsongesch1kt-ziJn 1s. Tevens mot echter worden vastgesteld dat de eandoenling nlet voor alle respondenten het meest bepalende facet van het arbeldsongeschikt$z 1 \mathrm{~m}$ 1s. DIt blijkt niet alleen lit zojulst genoend percentage respondenten dat de zlekte niet vervelender 
vindt dan het niet-werken $\left.(50 \%)^{5}\right)$, war ook ult het felt dat de andoening over het algemeen riet van prominent belang 1 foor de beleving van het arbeldsongeschlkt21. $n$ *

owerigen moet bis deze conclusle wel aangetekend worden dat in dit onderzoek slechts een beperkt antal apecten van het $z 1$ ek-z1 in in verband zijn gebracht met de beleving van het arbeldsongeschlkt-zijn: de last, de afhankelijkheld en de mate wamin men de gezondheld aangetas vindt. Het is niet onmoselifk dat minder praktiache aspeten van het hebben van een aandoenlng (b1jvoorbeeld de meer levensbeschouwel1 jke beteken1s ervan of het niet helemal gezond zijn op zich meer Invloed op de beleving hebben dan de bestudeerde variabejen. Een aanwlylng hiervoor $1 \mathrm{~s}$ het felt, dat, wanneer de zlekte invloed op de beleving doet gelden, dat vooral door midael van de relatle tussen het gezandheldsoordeel en de levenshouding gebeurt.

De zlekte 11ykt hierdoor 1 mmers voor een aantal mensen van belang als basis voor het zelfbeeld - zleke of gezonde - waarop de levenshouding mede gebaseerd $1 \mathrm{~s}$.

Bovendien blijkt de aradoening een belangrijke rol te spelen bif het al dan niet langdurif arbeldsongeschiktblljven. Toch doet ook daar de Invloed wan andere factoren niet woor die van de aandoenlng onder.

HET GEZIN

Gevraagd naar het belang van het gezin geeft vrljwel ledereen (96\%) aan het belangrijk zo niet heel belangryjk te vinden; men windt het gemiddela zelfis belargriyker dan werken, vrije tija of gezondheld. Hoe dat beiang precles moet worden opgevat $1 \mathrm{~s}$ nlet zonder meer duide11Jk, angerien de gezunsomstindigheden in de 1 interWews, vooral in emotioneel opzleht, niet grondig a de orde konden komen. 6 )

U1t de beschikbare informatle (vergaard ult gesprekken 
met man èn vrouw) komt echter wed een aanwlyzing roop de betekenls van het cezin nat voren. Narrate bet arbelosongeschlkt-2i in langer durt, verandert ex over het algemeen nogal het een en ander in zowel de praktische als de meer emotionele aspecten van het gezinsleven, hoewel toch nog $20 \%$ van de WAO-ers zegt dat er niks veranderd $1 \mathrm{~s}$.

Belangrijk is daarblj dat wel vanaf het begin vast stat dat het kostwinnerschap wan de man, een essentiele rol in het gezin is vervalien - het ontwangen wan een ultkering word niet als kostwinnen ervaren - doch dat niet onmldallijk duldelijk is wat daaroor in de plaats kont.

Wat betreft de verdeling van taken in het gezin tussen man en vrouw blljkt dat de meeste mannen steeds meer hulshowdelijke klusjes opknappen en meer de grote geldzaken gar regelen, en dat zelfs de helft van de respondenten zich met de beslissingen over de besteding van het hulshoudgeld gat bemoelen. opvallend hierbid 1 s dat de man zelden deze taken geheel var zijn vrouw overneemt, maar haar er meer bij gaat helpen (Bakke o.c., Ludwig \& collette o.c.). De hulshoudelijke taken bligven voornamelijk tot haar terrein beboren, evenals (het besilssen over) de besteding van het hulshoudgeld (zle ook Ballweg 1967). De grotere geldzaken ziln eveneens lets vaker het werkterrein van de vrouw dan van de man, maar behoren ook relatief vak $(30 \%)$ tot de dingen die de echtgenoten samen doen.

Zo betekent de grotere activitelt van de man, de uitbreding wan zijn ral in het gezdn, dat hil blinendrinet In het domein van zijn wrouw. Dat wordt hem niet altild In dark afgenomen. N1et zozer ondat his har wat klusjes ut handen neemt, madr vooral omdat hyj lnbreuk makk op har systeern, har indeling van har werkaamneden en haar wrijheld opmerkingen als "hij zit elgenlljk wel eens $1 \mathrm{n}$ de weg" " $1 \mathrm{k}$ kan m"n elgen gangetje niet meer gaan", "hij bemoelt zlch overal mee" werden 
zeer vak gemakt. Behalve tot klelne 1rritaties lelat d1t ook wel tot ernstiger spamingen. Het brengt rond 10\% van de vrouwen er toe om te zeggen dat het thus z1.Jn van de man overwegend vervelend en lastig is; $60 \%$ van de mannen geeft aan dat de sfeer in het gezin in de loop der manden slechter word en welen noemen de spanningen in het gezin blj de verwelende dingen en de veranderingen $1 n$ de tha tussen de 1nterviews.

Ondanks de grote mate van gezinsactivitelt van de man cook blyvoorbeeld wat betreft het optrekken met en verzorgen van de kinderen) bllyt byj de meeste echtparen de rolverdeling in hoofdlifien zoals die was toen de man nog werkte. Zelis wanneer de vrouw was gaan werken (bij 15\% van de wad-ems) ledude dit meestal niet tot een duldellyke herzlening van belder taken en verantwoorde11jkheden. Een volledige rolwlsseling $11 \mathrm{jkt}$ te worden belemmerd door de starheid warmee de meeste mannen en vrowwen vasthouden aan hun opvattingen over wat mannenwerk en wat vrouwenwerk is: onder meer budtenshuls het brood verdienen respectievelijk het hulshouden bestieren.

Het lifkt warschilnlijk dat dit een der hoofdoorzaken 1s van de valk groelende onderlinge spanningen. 7) Wat de man doet is t1jdsbesteding, niet het vervullen wan gezinsplichten. De vrouw daarentegen krijgt een zwaardere gezinsverantwoordel1jkheid: ze wordt verwacht naast haar gewone werk ook of zelfs in de eerste plaats, haar man op te vangen. Ze kan 1 mmers niet om zijn aanwezlgheid, Inclusief verdriet en chagrign, heen. 8 )

D1t lelat tot de conclusie date de grote beteken1s die het gezinsieven voor de man heeft, gelegen is in de weer, In de emotionele omgewing die de bedding wan zifn leven vormt; een leven dat zloh echter grotendeels bulten het gezin zou horen af te spelen en dat gevaelsmatig ook blidf doen, al is het in felte niet meer zo. ${ }^{9}$ )

Na het bovenstaande 1 s het nlet onbegr $1 . j p e 11 \mathrm{Jk}$ dat de beleving van het leven zonder werk voor de man wel af- 
hangt van de sfeer in het gezin en de reactie van de vrouw zoals hij die ervaart, doch niet van de conorete veranderlingen en de takkerdeling in het gezin.

Evenmin verwonderli jk is het, dat de emotlonele geansaspecten, ondanks hun belang, als achtergrond voor de beleving van het arbeldsongeschikt-glyn over het algemeen na het werkgems, het isolatiegevoel en de tijdsbesteding komen. 10)

\section{DE OMGEVING}

over het belang van de relatie met de omgeving als facet van het leven zonder werk is minder makkel1 $\mathrm{Jk}$ lets te zeggen dan over de andere facetten. Als we het gevoel wan soclale 1solatie bulten beschouwling laten thet hield 1 mmers nawwel1jks verband met de onderzochte kenmerken van de relatile arbeldsongeschlkte-ongevingl, kwam de omgeving in de interviews valywel noolt spontaan aan de orde, bijvoorbeeld blf de open wragen naar de vervelende dingen en naar de veranderingen tijdens het half Jaar tussen de interviews.

Erg op de voorgrond staan de ervarlngen met derden kennel1jk niet; $z 1 \mathrm{~J} z 1 \mathrm{Jn}$ er echter wel, zowel positieve als negatieve, warbil gezien de evaluatie wan de omgeving en de kenschets ran de buurt, de positieve op ieder moment lets vaker voorkomen. De veranderingen die in de loop der maanden optreden $z 1 \mathrm{jn}$ echter overwegend negatief.

De ongeving wordt met name minder meelevend en meen veelelsend geacht na verloop van tifd (vooral van 10 tot 16 maanden). De contacten met vilenden, kennisen en collega's nemen duldelijk af, die met de famlle bl1jwen vanaf 4 manden gemidaeld even irequent.

cok ervart men steeds lets meer stlgmat1 wer1ng: mesp. 47, 49. en 57\% heeft het gevoel dat men hem anders bejegent (vrljwel altijd op Brond van het felt dat hid nlet werkt), hem een profiteur vindt en/of dat men vindt dat 
hil best zou kunnen werker. Het meest negatieve stigmat1 aeringsitem - dat men hem een proflteur vindt - wordt door resp. 16, 18 en $27 \%$ (b1j resp. 4, 10 en 16 maanden) bevestigend beantwoord.

Teminste en wart van de WAO-ers, waarsch1jnl1jk zelfs ongeveer de helft, heeft derhalve het gevoel dat het nlet-werken niet als leg1tiem worat ervaren. 11$)$

Nu spreekt het min of meer vanzelp dat de legitimatie van het niet-werken een probleem $1 \mathrm{~s}$.

De enlge acoeptabele verklaring voor niet werken, name11jk die, welke de elgen schuld daraan ultalut, is lminers nog steeds: zlekte. Aan alle andere redenen voor langerarend arbeldaverzulm zit al gawh het luchtye van niet-w1lien-werken en dat wordt niet geaceepteerd. Het bewlys roor onschuld van arbeldsongeschikten wordt het meest overtulgend geleverd al de aandoening voor ledereen duldelijk zlchtbaar emstig 1s: de gehelde gevallen wan objectlef vaststelbaar zlek-zijn warvan het nietwerken hat voor ledereen zichtbare onvermijdel1jke gevolg 1 s (Petront 0.c., Kasisebaum B Bumann o.c.).

Helaa (1n dit opzloht teminste) lijden niet alle arbeldsongeschikten an zo duldelijk zichtbare kwalen; de aandoentng op $z 1 \mathrm{ch}$ was slechts bij eenderde der respondenten direct of b1j nader kennismaking zichtbaar en daamee is nog niet eens gezegd dat bij dege werken bók ziehtbaar onmogel1 jk was.

Een ander bew1 s van onschuld 1 s net: $1 \mathrm{k}$ mag niet werken van de dokter. Helabs toont de discussle over misbrulk van de sociale vooritentigen echter aan, dat het gezag van de medsche stand in dit opzicht tanende is: mabrulk - of men dat nu het Individu of het bedr1ff(sleven) In de achoenen sohulft - Impliceert immers dat de verzekerlngsgeneeskundigem mensen arbesdsongeschlkt verkitren die niet (zo erg) zlek (meer) zljn. Dat alt mede kan gebeuren op grond van de gerlinge plaatabaarheld van arbeldsongeschikten in het ambeldsbestel (de toepassing van ar. 21.2.a WAO) en dat de verzekeringsgenees- 
kundige zioh in deze niet altija on de tuin lat lelden 1.s de meeste merisen niet bekend. Lelfs al zou dat well bekend zijn, dan nog vind niet ledereen het begrijpe11Jk dat julst hif darvan het slachtoffer is of daarvan zou mogen profiteren. Sommigen kunnen (of willen) dan geen andere conclusle trekken, dan dat de arbeldsongschlkte niet wll werken (zle $0 . \mathrm{m}$. De Goede \& Massen 1980); een conclusie die de meeste arbeldsongeschikten niet als rechtvaardig ervaren.

Hierdoor staat ledere niet ernstig zieke arbeidsangeschikte voom een groot dilemma: zal hij zloh zoveel mogel1jk als zieke blifwen gedragen, veel thuis blijwen, weinis ondememen, naar de dokter(s) blljven gaan, over de aandoenlng blijwen praten en dergelijke, hetgeen het leven op zich miet veraangenaant, mar wel de goedkeuring voor het niet-werken "verdient": de man die $z$ 'n huis niet meer ultkomt uit angst voor de buren. Of zal hyj zich zo weinlg mogel1jk van de ziekte aratrekken, op stap gaan, zo veed mogelifk doen, wat voor hem zelf veel pliezleriger 1s, maar wel het rislco in alch houdt als proflteur te worden aangemerkt: de actleve, "klussende" WAD-er?

Hoewel dit probleem in de interviews aan de orde kwam naar aanlelding van de vraag naar de ervaren stlgmatisering, is op grond van deze informatle niet vast te stellen hoe men het allemma over het algemeen oplost en evenmin wat de betekents ervan is voor de beleving van het arbeidsongeschikt-21jn. Duldelijk is wel dat de relatie met de omgeving nawel1jks invloed op dle beleving witoefent: alleen de stigma-ervarling heeft bij 10 maander arbeldsongeschlkt-z1jn een redel1jke lnvloed op de algemene Levenshouding: hoe meer men w1ch "viroorceeld" voelt, hoe somberder men is. 


\subsection{De re1kw1jate yan de onderzoekul tkomsten}

De onderzokpopulatle bestond u1t gehuwe Nederlandse manmen wan $25-55$ Jaar, die op grond var bepaalde, nietpsychdsche andoeningen in 1974 of 19754,10 en 16 manden een zyektewet- resp. WAO-ultkering genoten via het GAK of het SFB, die nlet werkten en van wle niet vastatond dat $z 1 \mathrm{y}$ blnnen de onderzoekperlode weer aan het werk zowden gaan.

Howel de teekproef, in fielte een samenvoging van ateekproven, ult een aantal deelpopulaties, formeel niet representatier is voor de totale anderzoekpopulatie, zijn er geen redenen om aan te nemen dat de onderzoekuthomsten nlet tot de populatie generallseerbaar zouden zijn (zie ook par. 3.5). Verdere generallsatie tot alle arbeldsongeachikten in Nederland 1 s echter niet zonder meer mogelijk, op grond van de beperkingen die de populatle kenmerker. Deze zullen met het oog op de relkwidte van de onderzoekgegevens hieronder besproken worden (zle ook bljlage I.3).

a. Vrouwen ervaren het arbeidsongeschikt-zijn warschijnl1jk heel anders dan mannen. Voor de meeste vrouwen is naast de baan buitenshuls ook het werk binnenshuls van belang, zodat bij arbeldsongeschiktheld of twee werkterrelnen vervalien òf een, hetwelk door het ander betrekkel1jk gemakkel1jk enigermate gecompenseerd kan worden. Het gemis van het (waak part time) werk door vrouwen, hun problemen met de t1jdsbesteding en de gevoelens van sociale isolatie wlyn warschlynl1yk nogal anders dan die var mannen, zodat de onderzoekresultaten niet als geldend woor vrouwen kumen worden opgevat.

Hetzelfde geldt voor ongehuwden: het alleén thuls zijn versalit sterk van het thuis zijm temiden van vrouw en kinderen. 
b. Er is geen reden om aan te nemen dat de onderzoekultkomsten grasso modo n1et opgaan voor jongeren tot 25 jaar. Ten aanien van de 55-plussers kan dat eonter niet zonder meer gesteld worden. Zeker voo degenen die hun pensioen al min of meer zagen aankonem, is de arbeldsongeschiktheld wellicht nlet meer dan een vervroegde pensionering. Ook zll kumen echter het werk missen, moeite hebben met hun tisdsbesteding, zich gelsoleerd vaelen e.d. Al met al stat noch vast dat de onderzoekresultaten op hen van toepassing zin, noch dat dit niet het geval 1 .

c. Mensen met aangeboren afwijkingen en nieuwwormingen (samen 4\% van de WAO-toetreders 1n 1974 en 1975) en met psychische aandoeningen $(16 \%)$ zifn niet in het onderzoek opgenomen. 12 )

Daar de ziekte bil hen waarschijnlijk een heel. andere, valk overheersender rol. speelt dan bis de andere arbeldsongeschikten moet worden aangenomen dat de onderzoekulkomsten niet voor hen gelden.

d. Het spreekt vanzelf dat de onderzoekuitkomsten alleen Belden voor arbeldsongeschikten zonder werk, dus met meestal een 80-100\% arbeldsongesch1kthe1d.

e. Tussen de arbe1dsongeschiken u1t de GAK-en SFB-administraties bleken geen noemenswaaralge verschilien te bestaan. Daarult extrapolerend kan men aannemen dat de bevindingen tot arbeldsongeschikten van alle bearljfsverenigingen generaliseerbaar z1ju en warschijnilyk ook tot wegens arbeldsongeschiktheld nlet meer werkende (ex-) ambtenaren.

f. Hoewel het onderzoek arbeldsongeschlkten u1t 1974 an 1975 betreft zou het globaal waarschijnl1jk dezelfde resultaten opleveren als het in 1981 zou zign ultgevoerd, althans wat betreft de relaties tusser de 
onderochte onafhanke11jke en afharikel1jke variabe-

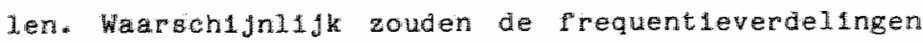
van diverae varlabelen er nu wel anders ultzien (andere opvatingen over werten welllcht, meer stigmat1ser1ng, andere rol/taakverdeling tussen man en vpou maschien) mar darmee is riet gezegd dat de Irviloed wan die factoren op de beleving ook veranderd zou zijn. Mogelijk is wel dat de ziekte nu een nog minder belangrijke rol zou spelen door het gestegen aantel toepassingen van WAO-artikel 21.2.a (z1e par. $1.2)$.

B. De sellectie van respondenten betreffende de verwachte langdurighe1d van het arbeldsongeschikt-zijn heeft waarschlynlijk geen beperkende invloed op de generajiseerbatarheld van de onderzoekutkomsten. Immers: blina alle an de owerlge criteria voldoende arbeldsongeachiktem werden tot het steekproefbestand toegelaten; doordat de prognose "yrijwel zeker werkhervatter" zelden door de verzekeringsgeneeskundigen gesteld werd.

Conclusle: de onderzoekultkomsten kunnen worden geacht te gelden voor Nederlandse gehuwde of daarmee in vergelijkbare omstandigheden verkerende arbeidsongeschlkte mannen van 25-55 Jaar, die thuls zitten en niet meer werken en wier aandoentng niet aangeboren, psychisch of sterk levensbedreigend $1 \mathrm{~s}$.

\subsection{Arbelasongesahikten, werkiozen en anderen}

Howel Inmlddels vast stat dat arbeldsongeschlkten minder tevreden z1jn met hun hulalge dagelljkse bestaan dan $\mathrm{zIJ}$ waren met hun vroegere levensomstandigheden staat niet zonder meer vast dat zlj ontevredener zijn dan het werkende deel van de Nederlandse mannelijke 
bevolking. Er 1s geen onderzoekmaterlal voorhanden, ook miet van andere onderzoeken, om de warschijnilibheld van een relat1er negatleve satisfactie van het dagelijks bestaan van arbelasongeschikten te toetsen.

Dezelfde redenatie geldt voor de levenshouding.

Er 1 s wel onderzoek gedaan nar levenssatisfactie, geluk, welbevlnden e.d., doch de operationalisatle van deze begrippen wijkt sterk af van die van de beleving in deze studie. Toch dienen twee gegevens in dit kader Wermeld te worden.

Het Soclaal Cultureel Rapport (1980) vermelat dat de ultspraak "soms heb je het gevoel dat het leven zinloos of doelloos $1 s^{\text {til }}$ door 13.3\% van de (voor de gehele Nederlandse bevolking representatieve) steekproef bevestigend beantwoord wordt. Van de arbeldsongeschikten 1 n het hiter beschreven onderzok antwoordt $30 \%$ bevestigend op aen analoge ultspraak "Je vraagt je wel erens af warrvoor je elgenlijk leeit", één wan de vier indicatoren woor de algemene levenshouding (par. 4.1). Het 11jkt derhalve vooralsnog aanneme $11 \mathrm{jk}$ dat de lievenshouding van arbeddsongeschlkten dan wel nlet extreem negatief, maar toch wel negatiever 1 s dan van de rest van de Nederlandse bewolk1ng. Een aanname, de wordt ondersteund door de resultaten van het onderzoek naar bet welbevinden door ormel (1980): arbeldsongeschikten (en werklozen) scomen duldellyk lager op de verschiliende Indices voor welbevinden dan de rest van de Nederlandse bevolking.

U1t ormel's verslag (o.e.) blijkt niet in hoeverte werklozen en arbeldsongeschlkten var elkaar verschllien in de beleving van hun situatle, noch wat de achtergronden voor hun beleving zouden kunnen $21 \mathrm{gn}$.

De beschlkbare studies nar de beleving wan werkloosheid geven hleromtrent ewenmin ultilustel. De beleving is daarin meestal geoperationaliseerd in termen van variabelen, die in het onderhavige onderzoek tot de facetten van het leven zonder werk ziln gerekend, ter- 
W1.j een simenvattende beleving ontbreekt lovesen 1977, Van Weze1 1972, Hamaker 1973 (overzichtaartikel)). overigens biljkt ult deze studles wel dat werklozen met vele zaken te kampen hebben, die arbeldsongeschikten evenzeer trefien: afgezien van operationalisatieverschllien komen bljvoorbeld globaal dezelfde vervelende en prettlge dingen naar voren.

Het is derhalve niet onwaarschijnlljk dat de onderzoekultkomsten wat betreft (de achtergronden van de beleving wan het leven zonder werk van arbeldsangeschikten in grate lignen vergelijkbar zouden zijn met de uitkomsten van een dergel1jk onderzoek b1j werklozen.

In al verband 1 set overigens van belang, dat ziekte in het leven van werklozen een belangrijker mol speelt dan men vak geneigd 1 t te veronderstellen (Kasl e.a. 1975, Gore 1978).

Een verschli tussen werklozen en arbeldsongeschikten zal er echter wel bestaan wat betreft de factoren die de eventuele werkhervatting in een vroeg stadium voorspellen. Het 1 s limers nlet aamemelijk dat voor werklozen de zlekteprognose en hulpbehoefte, zo er al sprake $1 \mathrm{~s}$ van zlekte, in dat verband een even belangrijke rol zullen spelen als voor arbelasongeschikten.

\subsection{Enkele (kn1tische) kant tekentngen}

\subsubsection{N1et onderzochte factoren}

De 15 onafhankel1jke vartabeien verklaren blijkens de transversale regreside-analyses tussen 31 en $64 \%$ van de satisfactievariantle per subgroep en tussen 32 en 58\% van de variantie van de levenshouding per subgroep. 13) Voor de 24 basisvarlabeleru 1 jn deze percentages 1ets hogef: $37-81 \%$ en $38-69 \%$ (alle slgniflcant bid $\leq .05$, tweerldalg getoetst). 
Hoewel er geen maatstar is om de grens tussen onvoldoende en voldoende verklaarde vardantie an af te meten 11 kken dit redelijke percentages woor en onderzoek als het onderhavige (exploratief, met gebrulk van een niet-gestandaardiseerde ragenl1jst).

Dit betekent dat vastgestield kan worden dat met de onderzochte aspecten van het leven zonder werk een redelijk deel van de achtergronden van de beleving daarwan in kaart z1jn gebracht.

Het spreekt echter vanzelf dat er nog andere factamen zijn die de beleving ran het arbeldsongeschiktzijn belnwloeden. Welke dat zlin kan niet preoles a angegeven worden, hoewel er enkele zo voor de hand Liggen dat ze hier aandacht verdienen.

Mutatis mutandis geldt het bovenstande ook woor de achtergronden van het al dan nlet langourlig arbeldsonGeschlkt-bl1jven: $36-37 \%$ verklaarde var1antie.

a. De onzekerheid ontrent de toekomst

B1J de wraag nar de vervelende dingen noemden na 4 tot 16 maanden respectievelijk 18,14 en $11 \%$ van de respondenten de onzekerheld ten anzlen van de zlekteprognose, de werkhervattingskans en de termijn warbinnen die werkelijkheid zou worden, als zeer onplezierlg. Het aratal onzekeren 1 s echter groter: na 4 maanden arbeldsongeschikt-z1 jn heeft $30 \%$ van de respondenten geen 1 dee over de ziekteprognase en bij 16 maanden is dat nog altija 15:. Darmee samenhangt de onzekerhe1d over al dan niet werkhervating en zo da, wanneer. 20 beeft na 4 maanden 35 geen 1 dee of werkhervatting mogel1 $\mathrm{gk}$ 1s; na 16 maanden is dat nog $30 \%$. Omtrent de dur van de arbeldsongeschiktheld tasten nog meer mensen In het dulster: \pm 49 resp. \pm 47 en $\pm 35 \%$.

Vooral de onzekerheld omtrent de duur van het nos arbeldsongeschikt-blifven I1jkt wan belang roor de beleving van het leven zonder werk: de onzekeren 
hebben een somberder algemene levenishouding. Het belang van deze onzekerheld ten opzlchte van de gebrukte basiswarlabelen viel helaas niet vast te stellen. De duupercept1e is daarblj namelifk niet opkenomen, daar er twifel bestond over de justheld van de coderung ervan ${ }^{14}$ ) (bovenstaande laatste drle percentages zijn dan ook slechts een benadering). Overlgens wijst het vermoedelijk verband van deze durpereptle met de beleving ar wel weer op dat het niet-werken belangr $15 k e r$ is dan de ziekte.

b. Contacten met behandelende artsen, OAK, SPB en GMD

In het deflutieve onderzoek ls geen aandacht besteed aan de contacten wan de ambidsongeschikte met de behandelend artsen en de soclale verzekeringsinstellingen, aangezien de interviewgegevens daarover ult de $2 e$ en $3 e$ onderzolesifase niet betrouwbaar waren.

Het 18 echter wel duldelljk geworden dat deze contacten belangrijk kunnen $21 j n$ in het jeven van de arbeldsongeschikten: men kan er hoop en zekerheld uit putten of er juist moedeloos en onzeker door worden; de contacten kumen prettlg of onplezlerig zign, aan de verwachtingen voldoen of julst niet. Voor alle arbeldsongeschlkten geldt dat blji vrlywel alle contacten de meeste aandacht an hun aamoening wordt besteed, ook al vinder zijgelf andere dingen misschien belangrijker.

Het spreekt wentel dat plezlerige en anplezlerige orvaringen met artsen en arbeldsdeskundigen invloed kunnen uttoefenen op de beleving van het arbeldsongesohikt-zyn. Hoe groot die invloed is kan weliswar moellifk geschat worden, maar zij lijkt gering geacht te kunnen worden op grond van het felt dat deze ervaringen noolt genoend zlin als antwoora op de (open) vraag naar de vervelende of prettige dingen wan de huldige situatie of nar de verande- 
rimgen van het afgelopen halr jaar. Mogelijk in de contacten met behandelend artsen en instanties niet frequent genoeg om een stempel op het leven zonder werk wan arbeldsongeschikten te drukken.

c. WAO-belangengroepen, buurt- en clubhulswerk

B1J de stant van het basisonderzoek (begin zewentiger jaren) werden arbeidsongeschikten everals werklozen well als een bijzondere categorle 1 inwoners van Nederland beschouwd, doch zij herkenden zelf hun gemeenschappeligke positie en problemen nog niet of nauwelijks en hadden evenuin veel onderling contact 6.9. omdat men het "voor anderen nlet weten wlide"). Voor zover er al soclail-culturele voorzieninger voor hen waren, makten $z 1 \mathrm{j}$ datran wrijwel geen gebruk.

In de loop der jamen is er echter veel veranderd. Butrt- en clubhulzen zijn meer activitelter gaan ontploolen voom mannen dle overdag t1jd voor derge11.jke zaken hebben en arbeldsongeschikten hebben zich gaandeweg georganiseerd in WAO/AWW-belangenverenlgingen, warran er al vele plaatselljke groepen zijn ontstaan, gebundeld in een Landeligk Beraad.

Deze verenigingen vervulien een zeer nuttige functie voor de deelnemende arbeldsongeschikten. Allereerst gat het gezegde "gedeejde smart is halve smart" op. Door de ultwisseling van ervaringen en de herkenning van de elgen problemen b1j anderen wordt de ellende lets verzacht. Bovendien hoort men weer ergens biy.

Tien Jaar geleden vormden arbejdsongeschikten nog. silechts een sociale categorie, dat w1 zeggen dat zlj door een gemeenschappel1jk kenmerk, het arbeidsongesch1kt-z1jn, gekarakterlseerd kondem worden. Dit kenmerk leldde toen echter niet tot het bewstziln van gemeenschappelijkheld, noch tot 
1nteractie tussen arbeldsongeschikten (Van Doorn en Lammers 1964). Iedere arbeldsongeschikte, geindividualiseer in de geneeskundige behandeling en in de begelelding door de soclale werzekeringainstanties, was alleen met zijn elgen problematiek. Deze problematlek, hun zwakk plek, 1s echter de laatste Jaren de basls geworden voor een (niewwe) solidaritelt, de duldelijk niewwe kracht geeft.

In Mar" terminologle: arbeldsongeschikten hebben zloh van een Klasse an sich tot een Klasse rur such ontwikkeld. Het belang daarvan is niet alleen dat men zich niet meer alleen voelt met $z 1 \mathrm{Jn}$ moellijkheden, mar dat de onderlinge solidaritelt, zeker van de platselijke groepen, de mogelijkheld schept on lets aan die moelifjkheden te doen.

Voor de actieven geldt dat mer zeer weel nuttige activitelten kan ontploolen, wardoor het gekwetste gevoel van elgenwaarde weer wat hersteld wordt. Bovendien is in veel van deze vereningen, soms met behulp van externe adviseurs, zoveel kennls en erwaring omtrent het arbeldsongesolikt-zijn, de ultvoerlingsinstanties, de regelingen en dergelijke verzameld, dat ook alierhande praktlsche hulp en advies geboden kan worder.

Kontom, van deelname aan dergelijke organisaties is belangrijke invloed te verwachten op de beleving van het arbeldsongeschikt-zijn, op de tijasbesteding, het gevoel overal butiten te staan, de ernst van het werkgenis en dergelijke.

Aangezien van de in dit onderzoek opgenomen arbeldsongeschikten er t1jeens de onderizokperiode (1974-1975) warschljnlijk slechts een enkelling aan dergelijke voorzlentngen deelnam ${ }^{15}$ ), 1s deze deelname als 1nvalod op de onderzokvarlabelen vrljwel zeker te verwarlozen. zou het onderwoek nu plaatsvinden, dam zou dit echter nlet meer opgaan. 
a. Persoonlijkheld

Hoewel in de literatur omtrent de gevolgen van ziekte en werkloosheid het belang van psychlsche kenmerker vam de betrokkenen rulme aandacht heeft gekregen (par. 2.1), zijn dergelijke kemmerken niet in het onderzoek opgenomen, en wel om de volgende tedenen.

In de eerste plaats zou dusdeligh onderscheid gemakt moeten worden tussen de min of meer stablele persoonskenmerken die de erwaring vam en de reactie op de verschillende aspecten en de beleving van het arbeldsioos bestaan mede bepalen, en de meer secundalre psychische kenmerken, die als reactes op de mieuwe levensomstandigheden moeten worden opgevat. Een dergelifk onderscheld is methodologisch moellijk te maken, tenzij gewerkt wordt met zeer ultgebreide, ultvoerlg geteste, gestandarasseerde en gevalideerde persoonlijkheldstests. Dan nog kan er twijfel rijzen omtrent de contaminatie tussen de psychische reacties en de beleving van het leven zonder werk (zie bijvoorbeeld ormel o.c.). Bovendien, en at was de tweede reden om persoon11jkheldskenmerken buiten beschouwling te laten, zou opname van desbetreffende tests een te grate belasting vormen, gegeven het toch al inspannende en Langdurige interview (gemlddeld 2 à 2 ì uur).

Blijft echter het f'eit dat persoonlijke elgenschappen als 1k-sterkte, neuroticlsme, weerbaarheld, frustratietolerantie, coping capacitelt (hoe ook precies gedefinieerd) zeker inwloed kumen ultoefenen op de beleving van het leven zonder werk. Deze inwloed kan op verachlliende manleren verlopen: de persoonlifkheid kan eer rechtstreekse 1 vloed op de beleving hebben (pljl 1 in onderstaand diagram); z1J kan 1nvloed hebben op de ervaring van de werschillende facetten van het lewen zonder werk c. $q$. de onafhankel1 Jke varlabelen in net onderzaek 
(p1j1 2) of interventeren in de relatie tussen de onaphankelljke variabelen en de beleving (pijl 3 en 4).

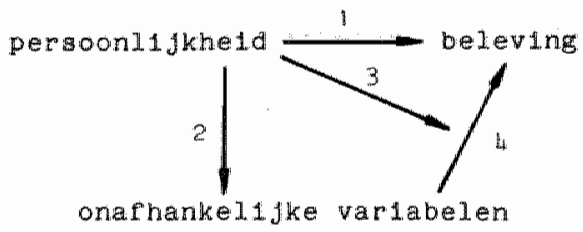

De vraag die nu aan de orde 1.3 is echter niet zozeer of de persoonlifkheld de beleving belnvloedt, doch of de tot dusverre vastgestelde relaties tussen afhankelljke en onafhankelljke varlabelen (p1j1 4) blijuen bestaan indien met persoonlljkheldskenmerken rekening wordt gehouden. Het antwoord kan hier helaas nlet gegeven worden, hoewel or enkele aanwijzingen $z 1 j n$ voor "waarschijniljk we1". 16)

Verondersteld wordt wel eens dat de levenssatisfactle, waarvan de beleving van het leven zonder werk als indicatle zou kunnen worden beschouwd, in zo grote mate door persoonlljkheldskenmerken wordt bepald dat men cen bepald niveau wan welbevinden of levensatisfactie als persoonskenmerk zou kunnen beschouwen (bijwoorbeeld Gadourek 1963). De resultaten van dit onderzoek ondersteunen deze veronderstelling nlet. Allereerst bligkt 1 mmers, dat de beleving na 4 en 16 maanden arbeldsongeschikt-zijn veel vaker a veranderingen onderhevig $1 \mathrm{~s}$ dan atablel blifft. In de tweede plats zou bovendlen de beleving van het leven zonder werk vollgens de verondersteliling niet al te zeer mogen arwijken van die van het leven met werk. En dat doet zij wel. 
Kortom: onderzoek naar de lnvloed ran de persoonligkheld op de beleving van het leven zonder werk is zeker de moelte wara. Op voorhand staat echter niet vast dat de resultaten darvan de conclusles van het onderhavige onderzoek zullen ondermi.jnen.

Werden bovengenoemde vier factor vermeld als mogel1jke achtergronden van de beleving van het leven zonder werk, de persoonlijkheld kan ook een ral spelen als achtergrond wan het langdurig arbeldsongeschiktbl1jven (zle blfvoorbeeld Wiersma $0 . c$. ).

Zoals in de inlelding van hoofdstuk 6 al is opgemerkt kan a1t onderzoek geen voldoende verklamg bieden voor blifvende arbeldsongeschiktheld. Daartoe zou immers op zifn minst meer gedetallieerde informatie over het arbeldsverleden, oplelding e.d. moadzakelijk zijn. Zo wijst Rruldenier $(0.0$.$) erop dat zeer waar-$ schijnlifk handarbeld in een niet-leldinggevende functie en een oplelding bestaande ult niet meer dan lagere school een grotere WAO-toetredingskans 1nhouden, vooral ten opzichte van leldinggevende bearbten.

Het laatste woord omtrent de achtergronden van langdurig arbe1dsongesch1kthe1d $c . q$. WAO-toetreding zijn echter nog lang niet gesproken. Het wachten $1 \mathrm{~s}$ in de eerste plaats op de resultaten van het groots opgezette WAO-determinantenonderzoek (een project van de Soclale verzekeringsraad en het Economische Instituut van de R1jksuniversitelt te Leiden, waanin factoren zowel u1t de tija vór de arbelasongeschiktheld als ult de eerste maanden van het arbeldsongeschikt-zijn worden onderzocht. 


\subsubsection{Theoret1sche perspectieven: u1tgangspunten woor nader onderzoek}

Blf de opzet van het basisonderzoek was de doelstelling nogal ongecompliceerd: Inzlcht werschaffen in de werschlliende facetten het leven zonder werk, zoals dat door arbelasongeschikten word ervaren. Voom het defintieve onderzoek 1 deze doelstelilng gespecificeerd tot het inzicht verschaffen in de belewing wan het leven zonder werk door arbeldsongeschikten. In belde gevalien 1 geen aandacht besteed an theoretische kaders, die de materladverzameling en de bewerking daarvan richting zouden kunnen geven, omdat bij de aanvang van het onderzoek niet voldoende bekend was welke theoret 1 che 1nvalshoeken bij het bestuderen van het arbeldsongegchikt-zijn ruttig zouden kunnen $z 1 \mathrm{ln}$. In de bijna 10 jaar die sindsdien voorblj gingen is inmldels door het elgen onderzoek, maar ook door onder zoek van anderen lets meer inzicht ontstaan in de theoretische dimensle van een aantal aspecten van (de beleving van) het arbeldsongeschikt-zijn. In deze paragraaf zulien deze theoretische Inzlchten worden vermeld, echter zonder ze grond $1 \mathrm{~g}$ te bespreken. Nadere Litwerking van de theoretische kaders betreffende het arbeldsongeschikt-zijn is een zaak van gerloht denkwerk ten behoeve van toekomstig onderzoek. Overigens is wel al duldelijk dat er nlet één, het gehele arbeldsongeschikt-zijn omvattende, theorle ontwikkeld zal kunnen worden, mar wel eer aantal verschlllende, op aspecten van het arbeldsongeschikt-ziln betrekking hebberie, theoretische uitgangspunten.

a. Het soclologlsche rolbegrip is reeds ter sprake Gekomen bij het onderscheld tussen positie- en stuatierolien en eveneeris blj de veranderingen in het gezin; het vervalien van de kostwinnergral. De problemen bly het vaststellen van een nleuwe rol 
voor de arbeldsongeschikte, een tiekte- of een arbeldsongesonikte-rol (zle de literatur op pag. 38) zijn op een groot aantal aspecten van het arbeidsongeschikt-zijn van toepassing. Niet alieen moet in het gezin na bewust onderling overleg en vooral onbewust "trial and errom" geprobeemd worden de normen en verwachtingen ten aanzlen van het gearag van de arbeldsongeschikte (en dat wan zijn gezinsleden) opnieuw te definieren, mar dat geldt ook voor de omgeving. Zowel ten opzlchte van de clrkel van bekenden, buren, vrienden en kennissen, als ten opzichte van de meer anonleme matschapplj, moeten nieuwe gedragsiegels worden geformuleerd. Belangrijk daarb1 $\mathrm{J}$ is de legltimatie van het gedrag wan de arbeidsongeschikte, warvan zijn niet-werken een essentieel onderdeel ut tmakt (Petron1 1969).

De roltheorie raakt hier het begrip stigmatisering (Goffmann 1969), dat w1l zeggen het op grond van een bepaald kenmerk (bljvoorbeeld het niet-werken) lemand als afwijkend bestempelen, het elgen gedrag daarop afstemen (bijvoorbeeld anders doen dan vroeger/tegen wel werkers) en de verwachtingen omtrent het gearag van de ander ook daarop baseren. Vaak 1mpliceert stigmatisering dat de gestlgmatiseerde een negatlef et1ket opgeplakt krijgt: de soclale status van een arbelidsongeschikte is lager dan die van een werknemer.

Bij nadere ultwerking van het rolbegrip, met name in termen van de mogelijke rolconflicten die arbeldsongeschikten mee kunnen maken conder meer gebrek aan overeensteming tussen hemzeif en $21 \mathrm{Jn}$ omgeving over ziln gedrag) en van de stigma-theorle blifken deze overigens niet steeds tot dezelfde hypothesen. Colman (1971) vindt bijwoorbeeld dat b1y orthopedisch gehandicapten de rolconflict-benadering wel, en de "soc1al rejection" benadering geen ondersteunig vindt (z1e ook freidson 1975). 
b. Zowel het rol-als het st1gma-begrip 1 mpliceren een belatie tussen (In dit onderzoek) de genandicapte en zin omgeving. De normen en vewachtingen omtritent het gedrag wan de een worden weersplegeld in de nomen en verwachtinger van het gedrag van de ander c.q. de matschapplj. Dit weorkerlgheldsprincipe is niet alleen terug te vinden in de arbeld (werkinkonen blywoorbeeld), maar ook in het gezin (mankostwinner, vrouw-hulishoudster) en vrifkel overal war mensen met elkaar te maken hebben.

De verstoring wan de wederkerlgheld, met name die, welke doo het wegrallen van de arbeldsrol ervaren word, vormt dan ook de kern van de problematiek van het arbeldsongeschkt-zidn. Niet alleen komt dit tot ultarukking in (de redenen woor) het werkgemis, maar ook in het gevoel overal bulten te staan nu fe niet meer werkt en zelfs in de moei11jkheden met de t1jdsbesteding (die njet nuttig genoeg gevonden wordt). Voor De Goede (1980) was dit aanlelding om de mogelifkheden van toepassing van de rulitheorle op arbeldsongeschiktheld te anderzoeken. Hader denkwerk en onderzoek zal moeten uitwijzen of deze benadering naast de rol- en stigma-benadering extra 1nzlcht in de problematiek van het arbeldsongeschikt-zijn oplevert.

c. Verschillende keren is opgemerkt dat zowel de levenshouding als de satisfactle met het dagelijks bestaan als referentlepunt het verleden hebben, met andere woorden: de arbeldsongeschikte beleefde zijn huldige situatie in vergelijking met zijn elgen vroegere omstandigheden.

Het 1 echter niet onmogelijk dat b1j het oordeel over het elgen arbeldsongeschlkt-zljn bewust of onbewust vergel1jkingen gemaakt worden met andere mensen in vergelijkbare of julst andere omstandigheden: arbeldsongeschikten, mensen met een aandoe- 
ning of handicap die wel (weer) arbeid vermiohten, chronisoh zieken of gehanolcapten die "er nog veel erger an toe zijn" e.a. Bovendien 1 s niet alujd duldelljk of, Indien gerefereerd wordt an de elisen omstandigheden voor het arbeldsongeschikt-women, hlerbij het volledig gezonde verleden in aanmerking wordt genomen of de periode toen men al wel ziek was maar nog werktie.

Een nache speciflcatie van de beleving van het arbeidsongeschikt-zijn in deze richting, met behulp van de relatieve deprivatie- en referentiegroeptheorie, zou zeker verhelderend kunnen zijn. Merton (1967) heeft o.a. in gijn bespreking van enkele resultaten van het project "The American Soldier" (o.a. Stouffer e.a. 1949) laten zien dat zulks boelende perspectieven biedt.

d. Stress- en copingtheorieen richten zich op het ervaren van problemen en het gedrag dat de mens ontploolt, tenelnde deze problemen te verwerken (Lazarus 1966). BlJ dit coping gedrag (andere wel georukte termen zijn adaptatie, a anpassing. adyustment) spelen verschlilende factoren een rol, waarbij begrippen als weerbaarheid en belastbaarheld centraal staan, de hulpbronnen waarult het Individu bij het verwerken van het problaem kan putten (Howard scott 1965). Ze worden niet alleen geindlceerd door oplelding, beroep(sverleden), inkomen e.d." mar ook door psychlsche kenmerken als zelfwardering, beheersingsorientatye, neurot1clsme e.d. (ormel 1980, Wiersma 1979).

In de coplingtheorle worden deze persoonskenmerken dus als interventerende variabelen beschouwd, en niet als rechtstreekse invloeden op net resultat van de coping, 1.0. de beleving wan het arbeldsongeschikt-zijn (zie par. $7.5 .1 . d)$. 
e. Een blyzondere hulpbron bij het verwerken van problemen ala zlekte en werkloosheld is de mate van "soclal support" (Gore 1978), dat wil zeggen de steun die de theke/werkloze/arbeldsongeschlkte ortvangt van $z 1 i n$ omgeving bif de verwerking van de problemer. Blyroorbeld de gezinsomstandigheden, of minstens een aspect daarvan (bl) ommel (o.c.) de vertrowwelifkheid met de partner) worden in deze benadering als interventerende variabelen beschouwd tussen het arbeldsongeschikt-zign en de beleving als onathanke11jke en afhankel1yke varlabelen.

bicht hier tegen aan ligt de netwerkbenadering. Freidson (1975) saat er vanut dat een Individu niet geheel alleen tot bepalde meningen of gedrag komt, mar dat hij beinvloed wordt doar het soclale netwerk warvan hij deel ultmakt. Het verschil met de social support benadering is at het netwerk nlet alzeen intervenlërende, mar ook rechtstreekse Invloed kan hebber op bijvoorbeeld de beleving van het arbeldsongeschikt-zign (zie voor een litgebre1de netwerk-analyse 1.v.m. medische consumptie Mootiz 1.981).

Ter afsluting wan dit beknopte overzlicht var theoretische aanknopingspunten bif de bestudering van het verschylysel arbelasongeschiktheld, zoals dat door arbeidsongeschikten wordt ervaren, kan worden opgemerkt dat deze aanknopingspunten, ondanks hun formele afwezlgheld b1t de opzet van het onderzoek leven zonder werk, darbly toch al Invloed hebben gehad. De ketize var versohiliende variabelen werd soms lmpliclet enligsins op deze theoretische benaderingswiJzen afgesternd.

Lou er opnleuw onderzoek op d1t terrein plaatsvinden, dan 1 s het echter mogel1jk en noodzakelljk de keuze van de varlabelen en vooral van de operationalisatie ervan, stoviger te funderen op de theoretssche basis. 
Bis de interpretatie van de bevindingen bledt dat grote vooraten.

\subsection{Habeschouwing}

Het onderzoek is miet in de eerste plats opgezet met het doel praktische aanbewelinger te doen ter verbetering var de levensomstandigheden van arbeldsongeschikten of richtlijinen an te geven roor het beleld betreffende deze niet-werkers; daarvoor was bij de aanvang van het onderzoek onvoldoende bekend wat hun belangrijkste bljzondere kenmerken en problemen zouden z1jn.

Desondankis zijn er enkele onderzoekultkomsten die 1 mplicaties hebben voor de behandeling en begelelding van arbelasongeschlkten. Z1j zulien hier, in samenhang met wat algemener besplegelingen, beknopt worden geformuleerd als een soort richtingaanwijzers voor beleid.

a. In de eerste plaats 1 s duldelijk dat de leefbarheld van het leven zonder werk bevorderd zou kunnen worden door middel van verbetering van de tijdsbesteding. Hierbij moet gedacht worden aan het ontwikelen van een meer gevarieerd en minder hulsgebonden activiteltempatroon, warainnen bezlgheden die van nut en warde zign voor anderen een grotere plaats zouden moten innemen dan over het algemeen het geval is: activiteiten in verenigingen, vakbonden, politiek, buurt en clubhuls, WAO-belangenverenigingen, vrijwil11 gerswerk etc. 17 )

Met een gevarleerde tijasbesteding kan de verweling verminderd worden; met minder u1tslultend Individueel gerlcht en uitgevoerde bezigheden kan het matschappel1jk relatiepatroon weer worden ultgebreld.

Dit 1 geen nieuwe gedachte: de Soclale Verzekeringsraad heeft niet voor niets elnd 1977 een rapport uitgebracht warin bepaalde soorten vrlfwil11gerswerk 
onder bepaalde voorwarden met behoud van de u1tkeIng worden toegegtar.

Een probleem hierbij 13 well, dat de SVR daarbil ultslultend pro deo werkaameden op het oog heeft, terwill voor welen het nut en de warde van de werkzabmeden nos steeds vooral in geld wordt utgedrukt. Hoe dit is op te lossen 1 s vooralsnog niet duldelijk. Bovendien mot men zich wel realiseren, dat warachilnIlyk slecht een deel van alle niet-werkers tot dit soort werkzamheden te bewegen $1 \mathrm{~s}$. Mensen met minder oplelding en lagere beroeper hebben er over het algemeen minder belangsteling voor.

D1t geldt volgens Houben (1972) en Knulst (1978) ook voor meer vormingsgerichte bezigheden als cursussen. cursussen, die op het vergroter van de kanser op de arbeldsmat gericht zijn mogen zloh weliswar in meer toeloop verheugen dan andere, maar ook deze trekken meer hoger opgelelden.

Aangezien bovendien blijkt dat niet-werkenden minder dan werkenden gebrulk maken van gesubsidieerde woorzieningen op het gebled van cultur en recreatie (sportaccomodatie, musea, theater en mualek, blol1otheek e.d.) (CBS 1977, SCP 1980), rijst de vraag welke voorzlen1ngen men dan nog wel zou kunnen treffen om grote groepen nlet-werkers te steunen blj hun tijdsbesteding.

Ter beantwoording van deze vraag is allereerst een systematische inventarisatie en evaluatie nodig van alle projecten die de latiste jaren ten behoev van arbeldsongeschikten on werklozen zifn opgezet, mestal op gemeentelljk of regional niveau. Kennis omtrent de achtergrondem van de deelnemers, hun motivathe, successen en mislukkingen, aard van de activitelten en van de organisatie (professionele lelding of "arbeldslozen zelfbestuur") zijn onontbeerlijk om tot een gefundeerd oordeel te komen over de wense$11 \mathrm{jkh}$ 1d en inhoud van t1jabestedingsmatregelen. 
Bovendien $11 \mathrm{Jkt}$ het nuttig om bijwoorbeeld de WhO-belangenverenigingen in te schakeier ter mventarigatio wan de behoerten op alt gebied.

b. Ram de tijdsbesteding nog opgevat worden als "manupuleerbare variabele", het werkgemis 11 jkt dat in het geheel niet. Toch is het werkgemis in principe ook te belnwloeden, namelijk door het opheffen van de valledige tegenstelingen tussen werken en miet-werken. Warneer de arbejdsparticipatie van volwasen mannen niet meer 40 uur per week in beslag zou nemen maar veel minder, en hur deelname aan andere matschappe11.jke activiteiten en het hulshouden sterk zou toenemen, zou Inmers het wegvalien van het werk een andere betekenis hebben dan nu.

De alscussie over verkorting van de arbeldsdag, deeltijaarbeld e.d. op grote scharl is in den lande weliswar in volle gang, zlj het messtal met het oog op andere doelstellingen dan het beperken wan het werkgemis van nlet-werkers (zle literatur pag. 15 en b1jvoorbeeld Tellegen 1980), doch de dag is nog ver waarop we het gewoon zullen vinden om nilet meer $B$ u ur per dab, 5 dagen 1 de week, te werken.

Toch is het bevorderen van deeltijdarbeld, ook afgezien van die gewoontevorming, voor arbeldsongeschikten wan belang. Inmers: werkhervatting is vaker voor een par uur per dag mogelifk dan voor valle dagen en bovendien, en nog belangrifker, kan uitval uit het arbeldsproces dikwljls woorkomen worden wanneer niet de hele dag (of de hele week) behoeft te worden gewerkt. Woorkomen is ook hier beter dan genezen. We1licht draagt de toekomstige Wet platsing Minder Validen in dit opzicht bif tot het verzachten van de arbeldsongeschiktheidsproblematiek.

c. De vorming van andere arbeldsgewoonten hoeft rilet noodzakel1jk voorafgegaan te worden door een andere 
houding Jegens arbeld, $21 \mathrm{~J}$ zal er echter zeker door worden gewolga. Ook in dit opzlcht hebben we nog een lange weg te garn, 1 in tegenstelling tot wat degenen, die menen dat het arbeldsethos al sterk 1 v verminderd, veronderstellen.

Het begrip arbelasethos of arbeldsmoraal dulkt de laatste jaren regelmatig op in de discusises rond werkjooshe1d, arbeldsongeschiktheld, zlekteverzulm en mistutk van sactale voorzieningen. Zonder dat dit begrip duldelijk gedefinteerd wordt, wordt het $1 \mathrm{n}$ die diacusiles 1mpliclet opgevat als "de 11 tot werken", warblf expliclet wordt gesteld dat deze vermindert of verminderd 1s, hetgeen dan als mede-oomzaak voor bovengenoemde verschljnselen wordt beschouwd (onder meer Emanuel 1979, De dalan 1980, Hartog 1979). Maast deze afnemende orientitie op werken wordt wel de toenemende orisntatie op vrije tija gestela, gelntraduceerd door Van Delden (1970) en o.a. ultgewerkt door Ph111psen (1974).

In de gedachtengang van de afnemende arbidsorientatile zit de mening opgesloten dat velen tegenwoordig liever niet dan wel werken. Een menlng die in tegenspraak 1 met de ultkomsten van dit onderzoek.

D1t noopt tot enlge nadere beschouwlng van het begrip arbeldsmoral of arbeldsethos en zijn relatie tot de m1 tot werken.

Dan blifkt allereerst dat de verwarring gedeeltelijk wordt veroorzaakt door de onduldelijke definlering van het begrlp abeldsethos. In de Inlelding is geatela dat de kern ervan gevornd wordt door het gevoel dat arbeld een plicht 1s. Hagendoorn e.a. (1981) rafelen het arbeldsethos, in navolging van Weber. ulteen in de componenten discipline, werkdwang, zelfbeheersing, ongenakbatrheld en onmisbagheld, warbij het gevoel u1troerder te $z 1$ In van een bovenpersoonllfke doelswelling van belang 1 .

Daar er nauwellyks kwantitatleve gegevens bekend $z 1 j n$ 
over een zo gespeciflceerd arbeldsethos 21 ilier geconstateerd dat de veronderstelling, dat het arbeidsethos in deze zin afneemt, geensins ondubbelzinnis vastistat onder meer omdat de opvatulig dat werken een pllcht is nog wijd verbreid $1 \mathrm{~s}$ (pag. 29). Maar zelfs als we ervan ultgaan dat het arbeldsethos afneent, of verminderd is, $1 \mathrm{~s}$ daarmee nog niet vastgestela dat er velen llever nlet dan wel werken. Duldelijk is immers geworden dat de wil tot werken nlet alleen gevoed hoeft te worden door de morele druk op (beroeps)arbeld, maar ook gebaseerd kan ziln op het gegeven dat een aantal menselljke behoeften (nog) wrijwel alleen door arbeld kunnen worden vervuld.

In samenhang hiemee stat het gebrek an duldel1ykheid in verscheldene discussies over het afmemende arbeldsethos betreffende met versch1l tussen de orlentatile op het elgen werk en die op werken in het algemeen.

Becker (1980) heeft al eens opgemerkt dat het gebrek aan motivatie, inzet, hart voor de zaak e.d." dat werknemers wel door werkgevers verweten wordt, nlet betekent dat men helemal geen werk w1 hebben of houden. Het houdt slechts in dat de "traditionele" volledige en kritiekloze overgave aan het werk en de werkomstandigheden minder vaak voorkomt dan enige decennia geleden en dan sommigen zouden wersen.

Het felt dat de orlentatle op arbeld als centrale zlngeving wan het leven en als doel van onvoorwardeIIjke 1nspanningen terrein heeft verloren ten gungte van bljwoorbeeld de orientaties op gezin en vrije tifd, houdt nlet in dat de arbelderol zonder meer inwisselbaar is voor de gezins- of vrljetijasrol.

Dat w1 zeggen dat een minder sterk arbeldsethos of een minder sterke arbeldsorientatie wel kan leiden tot blfvoorbeeld frequenter tydelijke afwezigheid van het elgen werk, maar veel minder vaak tot een 
melf verkozen langdurig of blifvend compleet arbelds1oos bestaan.

Dit hele betoog leldt tot de conclusie dat naast de vorming van andere arbeldsgewoonten en het ontstar van een ardere arbeldsorlentatle sroot belang checht moet worden aan de tljabesteding naast (deelt1ld)arbe1d. Slechts indien daarin mogel1jkheden Bevonden worden om de behoeften te bevredigen die nu nog vrljel uitslutend door arbeld worden verwuld, kunnen werken en niet-werken een gelijkwaardige plats 1 in het 1 dividuele leven innemen en elkaars alternatieven worden.

d. Een vierde consequentle van de onderzoekuitkomsten betreft de aandoening als focus van professionele behandeling en begeleiding.

Het apreekt vanzelf dat ledere arbeldsongeschikte zoveel curatleve geneeskundige zorg krijgt als hij nodig beeft. Niet alleen ten behoeve van een eventuele werkhervatting, mar ook ter bevordering van een zo aangenaam mogelifk leven zonder werk 18 zorg voor optimali herstel en/of verzachting van de 11 chamel1jk en psychische consequentiles van de aandoening noodzakel1 jk.

Minder noodzakel1jk $1 \mathrm{~s}$ daamentegen de aandacht ale over het algemeen door de verzekeringsgeneeskundige aan de arbeldsongeschlkte wordt besteed, war die aandacht voornamelifk gerleht $1 \mathrm{~s}$ op de controle van de leg1tmite1t van het arbeldsverzulm: op de vasttelling dat de arbeldsongesch1kte "echt" een werkbelemmerende aandoening heeft.

Dat het vastatellen van abjectleve arbeldsongesohiktheld lang niet altija mogelifk 1s, kan inmlddels bekend verondersteld worden (zle blyvoorbeeld de discussles in de laatste jaren omtrent de taak van de verzekeringsgeneeskund ( $1 \mathrm{~g}$ ) e in $0 . a$. het Tijdschrift voor soclale Geneeskunde); duldelljk is ook dat deze 
contrale dikw1ils vernederend is voor de betrokken arbeldsongeschikte.

Aantrekkel1jker voor belde partijen en alnwoller, $11 \mathrm{jkt}$ het de niet-curatieve geneeskundige andacht te rlohting op mogelijke werkhervatting en dus op de verrichtingen wartoe de arbeldsongeschikte wel in staat 1s, in plaats van op wat hij niet (meer) kan. De zlekte speelt immers een belangrlyke ral bij de werkhervattingsmogel1 ykheden.

Voor het werk van de verzekeringsgeneeskundigen bij de bedrijfsverenigingen, het GAK en de GMD zou dat een duldelijke accentverschulving 1nhoudien; bovendien zouden de contacten met onder andere bedrlffsartsen en arbeldsdeskundigen geintensiveerd moeten worden. De geneeskundige en arbeldskundige anaacht woor de cliknt met het oog op mogelijke werkhervatting moet vaker dan nu het geval is vór het elnde van het zlektewetjaar gestalte krijgen, om de eventuele werkhervatting zo spoedig mogelijk te kunnen realiseren.

Het felt dat de aandoenlng voor de beleving van het arbeldsongeschikt-zijn niet de meest bepalende factor is, impliceert dat de begeleiding van ultkeringsgerechtigden ook, of julst op de andere facetten van het arbeldsongeschikt-zijn gerlcht zou moeten $z 1 j \mathrm{n}$. Dit betekent, gegeven de huldige organisatie van de ultvoering van de ziektewet en de WAO dat de begelelding van de problematlek betreffende het werkgemis, de soclale 1solatle, de tijdsbesteding en het gezin meer rulmte zou moeten krilgen binmen de bedriff 1 veren $1 \mathrm{~g} i n g e n$, het $G A K$ en de GMD. ZHI hoeven de $1 n$ deze sferen gewerste activiteiten niet noodzake11 Jk zelf ter hand te nemen, maar oplettendield en samenwerking met andere instellingen in deze 18 wel. aan te bevelen.

Het voert te ver or hier de ultgebreide discussie omtrent de toekomstige organisatie van de sociale verzekeringen weer te geven lals dat al mogedijk is, 
gezien de vele bljaragen in nota's, wakbladen, kranten en t1jaschiften).

Geconstateerd moet echter wel worden dat, waar het de Zlektewet en de Who betreft, de geneeskundige inbreng In de ultvoering van deze wetten relatief rulme aandacht krijgt (0.a. het debat over intercolleglale Informatle ustwseling, wehelding van behandeling en controle is zeer levendig) en de arbeldsdeskundige inbreng, alsmede blyvorbeeld het voorzieningenbeleid nogal weinig. U1t het bovenstaande moge blijken dat een groter evenwicht van deze accenter aanbeveling verdient. Mede met het oog hierop is de poging om de arbeldsongesch1khe1daverzikeringen met de verschillende werkloosheldsregelingen tot één loondervingswet te integreren toe te julchen (z1e 0.m. Van zaal 1977, V.d. Doef en V.d Re1jden 1978, Berenschot 1979, Interimrapport C1e Lamers 1979). Het 11gt 1mmers voor de hand dat bij begelelding van alle niet-werkenden binnen éen wettel1jk kader het hoofdaccent zal $11 \mathrm{ggen}$ op hun gemeenschappelijk kenmerk: het nlet-werken. De noodaakel1yke bijzondere aandacht voor mensen met bljzondere nevenkenmerken zoals een aandoening. kr1jgt dan waarschijnl1jk makkelijker de plaats die hier beoogd wordt, dan blj een blifvend aparte wettelifke regeling voor arbeldsongeschikten en voor werklozen. 


\section{Noten hoofdstuk?}

1. Deze volgorde komt ook maar voren ult ter controle ultgevoerde regressle-analyses van de algemene beleving (de gesommeerde 1 temscores van de acht belew1ngsitems, dus de twee dimersies blj elikarar).

2. D1t geldt volgens knulst (1977) ook voor andere niet-werkencien, met name werklozen. In aljn onderzoek nar de t1jdsbesteding van de Nederlandse bevolking in oktober 1975 blijken de niet-werkenden een veel hulselijker t1Jasbestedingspatroon te hebben dan de werkenden.

3. Eer constatering ook van Koslen (1975), na onderzoek bij 30 naar het Nederlands Instituut woor Studie- en Beroepskeuzebegele1ding verwezen WA-ers.

4. Zle par. 1.2: niet alle nlet-werkende arbeldsongeschikten zidn volledig ongeschikt tot het verrichten van alle arbeld; (gedeeltel1jk) herstel impliceert niet automatisch (gedeeltelifke of aangepaste) werkhervating.

5. Dit ciffer moet overigens met enige voorzichtigheid gehanteerd worden. Inmiddels is immers duldeilik geworden dat zowel de zlekte als het niet-werken een scala van onderling gedeeltelijk samenhangende ervaringen impliceren. Dit betekent tezamen met het felt dat de vraga: "Wat vindt u vervelender, het niet-werken of het $21 e k / g e h a n d 1-$ capt zifn" is gesteld aan het elnd wan het Interwiew, nadat alle facetten van het leven zonder werk de revue gepasseerd $z 1 j n$, dat het onduldelijk $1 \mathrm{~s}$ wat de respondent precles onder de (gevolgen van de) zlekte danwel onder het nilet-werken heeft verstaan bij het beantwoorden van de vraag. Desondanks blifft het een felt dat niet meer dan $50 \%$ de wikte als het meest vervelend noemde, zodat het primat van de zlekte in leder geval niet voor alle arbeldsongeschikten vaststat (z1e par. 1.4).

6. Het $1 \mathrm{~s}$ moe111jk om informatie te werkrijgen over de intieme aspecten van het huwe $11 \mathrm{Jk}$ - en gezinsleven $1 \mathrm{n}$ een interview war zoveel meer onderwerpen an de orde moten komen in een beperkte t1jd. De informatie over het gezin 
1. werzameld door midel van een aantal mondelinge vragen aan de man, alsmede achriftelijke vragen aan man en vroun.

7. Werklozen en arbeldsongeschikten wordt dikwills een groter aantal echtscheldingen toegeschreven dan de rest van de Nederlandse bevolking. Hoeveel er in de onderzoekgroepen voorkwamen 18 helaas niet vast te stellen.

8. Dat desondanks slechts $10 \%$ van de vrouwen zegt het thus zijn van de man vervelend te vinden moet warschijnlijk toegeschreven worden aan de soclale wenselljkheld: als liefhebbende echtgenote màg je het elgenl1jk niet vervelend vinden om je man om je heen te hebben.

9. Voor de vroum geldt de emotionele functie van het gezim evenzer. Het grote verschil tussen man en vrouw $1 \mathrm{~s}$ echter dat har leven zich grotendeels binnen het gezin af"speelt: het gezin is ook haar werk. Vandaar dat de prakt1sche veranderingen daarin haar meer deren.

10. Al $1 \mathrm{~s}$ het gezin niet rechtstreeks van belang voor de beleving van het leven zonder werk, toch bestaat de mogelifkheld dat het wel invloed ultoefent en wel als intervenierende varlabele: de invloed van de onafhankelijke varlabejen kan in versahillende gezinsomstandlgheden verschiliend $z i y n$, bijvoorbeeld versterkt of verzwakt worden. De zogenaamde "soclal support" hypothese heeft hierop betrekk1ng (Gore 1978, Ormel 1980, Ovesen 1977).

11. Het eerste en het latste st1gma-1tem - dat men anders doet of vindt dat hif best zou kunnen werken - hoèven niet altijd in afkeurende $z i n$ bedoeld te ziln. Waarschijniljk is dat echter vaker wel dar nlet het geval.

12. De leeftigasbeperking houdt in dat de populat1e $62 \%$ van de WAO-toetreders bestrijkt. Leeftida en diagnose samen beperken de onderzoekpopulatle tot $42 \%$ van de WAO-toetreders 1 in 1974 en 1975.

13. Voor de totale durgroepen zijn de percentages verklaade variantle respectleve11 Jk $34-35 \%$ en $32-36 \%$ voor de 15 onafhankelifke variabelen plus leeft1Jd, berrop en aandoendng. 
14. Waarschijnlijk is de mening van de respondent bij alt 1 tem niet alt1jd even onarhankelijk van de interpretatie van de interviewer in het interviewprotocol terecht gekomen. Bij de onzekerheid omtrent de ziekte- en werkhervattingsprognose geldt dit probleem niet. Deze laatste onzekerheld heeft, gescoord als dichotomle, echter géén invloed op de beleving.

15. In het vooronderzoek 1 op de 30 gelnterviewde arbeldsongeschikten. In het basisonderzoek is naar deze activiteiten nlet gevraagd, maar ze zijn ook nlat spontaan genoemd. Althans niet expliclet genoeg om door de interviewers, zoals afgesproken, vermeld te worden.

16. Het 1tem "anderen hebben vaak meer over je te zeggen dan jezelf" (uit een vanwege te grote onduldelijkheden nlet gebrulkte serie ultspraken) zou kunnen worden opgevat als indicatie woor de zogenaamde externe versus interne beheersing. Dit 1tem hangt zowel met de beleving als met verschlliende onafhankelljke varlabelen samen, doch laat de 1 nvloed van de onathankelijke varlabelen op de beleving onaangetast.

Bovendien vindt Koslen (1975) dat de aanpassing aar het leven zonder werk weliswaar bemoell1jkt wordt wanneer er psychische problemen zijn, doch dat grosso modo het aanpassingsproces voor alle arbeldsongeschikten ongeveer hetzelfde verloopt. Vrij vertalid zou dit betekenen dat de relaties tussen onathankel1jke en afhankel1jke varlabelen niet afhankelljk zijn van de psychische gesteldheld der arbeldsongeschikten.

overigens moet de gestelde vraag naar het overeindblifven van pljl. 4 nilet verward worden met de vraag naar de verhouding tussen persoonl1jkheldskenmerken en objectleve sltuatlekenmerken ten aanzien van de beleving. ormel (1980) laat zien dat u1t vele onderzoeken, inclusief bet zijne, blijkt dat de invloed van persoonlljkheldskenmerken op het algemeen welbevinden groter is dan de objectheve levensomstandigheden. 
17. Dut 1 een pleldool tègen de mening dat (vrlywel) alle menselidke activitelt tot arbela dient te worden gepromoveerd. Er moet Julst rulmte blijwen voor een breed scala van nlet-werkmogelijkheden: niet geprofesionaliseerde, dus niet min of meer pasalef te consumeren, mar veel. meer actief zelf te organiseren en creatlef te ondernemen activitelten. Zle ook het voorstel van De Swaan ter hervorming van het welzijnswerk (de congregatie-vorming, 1981 ) en Il11ch' pleldool voor het "right to useful unemployment" (1978). H1erdoor komen ook (weer) de mesorollen aan bod (z1e pag. 142$)$. 
SUMMARY

The study "Life w1thout Work" found its or 1gin lis a paradax: on the one hand work is in this time as before one of the most cher1shed values in soclety; on the other hand the percentage of grown-up people not particlpating in the labor force 1 s decreasing.

chapter 1 looks at the factors underlying this increase in the numbers of people who do not work. Furthermore, the 1 mportance soclety attaches to "work" as a fundamental aspect of $11 f^{\prime e}$ and the consequent difflculties of a life without work are discussed. Th1s introductory chapter concludes w1th an outline of the reasons why those who are out of work because of a disability have been chosen as the maln subjects of study.

Chapter 2 formulates the questions the study sets out to answer and outlines the general design of the study. The questions are as follows:

1.a. How is unemployment experienced by the disabled at various points in time - after being unemployed for 4 , 10 and 16 months?

b. What are the main factors influencing such experlence?

2.a. What changes occur after a number of months of beling unflt for work, both in the situation as such and in the reaction of the person concerned?

b. Are there demonstrable causes for the changes in the way in which unemployment is experienced?

a. Is the way in which unemplayment $1 \mathrm{~s}$ experienced at the 16-month mark Infiuenced by experlences earlier on, rar instance those noted at 4 months?

3. Are there alferences after 4 month between those unfit to work for longer periods and those who return to work within six months?

The study takes as a tarting polnt the experience of belng unflt for work in all 1ts many and varled aspectis. Some of 
those atudied were: the nature of the disability, the way time 1 s spent, the family situation, the subject"s views on work in general and his own line of work in partieular, and the soclai environment.

Interviews were conducted wh married Duteh males between 25 and 55 who, because of varlous somatic complaints, had been recelving elther health insurance or disability benefits for 4, 10 or 16 montho through the Gemeenschappel1Jk Administratie Kantoor (Jolnt Administration offlee) or the stichting Sociaal Fond BowwniJverheld (Asociation for Soclal security In the Busla1ng Industry).

The study was both cross-sectional and longltudinal. Thus, three groups of sublects who had been unemployed for 4 (757 men), 10 (496 men and 16 (387 men) months and another group of 74 , men, for whom data for all three of the sald moments in time were avmilable, were studied.

Chapter 3 describes the sample as viewed from varlous angles. In addition, the subjects" experlences and the background factors to these expertences were divided 1 into 2 and 24 separate varlables, tespectively.

Chapter 4 concerns the answers to the flrst section of the questions posed. Whth regard to the dally routine, the overwhelming majority of the respondents experienced their situation in negative terms. Comments such as the following were glwen: "If I had the cholce, I'd return to work today rather than tomorrow". "I'm not very happy about things as they are" and "The good things don't make up for the negative aspecto". However, the1r attlude to life in general was much more opt1mit1c: "I'm not having such a bad ine" "Life 18 not too bat" ano. "I'm falrly optimistic about the future". The degree of atisfaction with the dally routine proved in the flrst 1nstance to be related to the lack of work and the atisfaction provided by the work done formerly: the more the 1ndlulatul missed his work and had previously obtained satis- 
faction from 1t, the more he was inclined to be dusatisfied with a life without work.

The general at itude to IIfe appeared to be flrst and foremost related to a sense of soclal isolation: "If you don't work, you"re excluded from practlcally everything".

The evaluation of the way the individual spent his tine occupied an important second place in both the experience of the dally routine and the general attitude to life: experlences tended to be negative in proportion to the degree to which the activitles carrled out were seen as useless and not pleasant or interesting.

Generally speaking, the famility situation was the third background factor influencing the experience of being unemployed. This was followed by the (serlousness of the) lilness and the social enviromment.

Chapter 5 concentrates on the second section of the questions posed. In all aspeots of belng unflt for work changes were found to occur after 4-16 months. A striking observation, in this connection, was that when changes occurred, the directIon was malnly negative, except for the overall experience of belng unflt for work. Particularly the subject's satisfaction with dally life prowed to become more positive with increasing time.

A possibie explanation for this may be found in man"s "natural" adaptation mechanisms: the abli1ty to become accustomed to a sltuation and to accept 1t. One fact supportIng this assumption is that nost changes occurred independentily of one another.

The subject's degree of satisfaction with thelr dally life after 16 months of unemployment was evidently established at an early stage: respondents who sald they were satisfied remalned so, whereas those who sald they were not continued to be relatively dissatisfled. However, the attitude towards 11re In general, at the 16 -month mark, was found to be malniy affected by the experiences of that particular moment. 
Chapter 6 indlcates that at a relatively early stage (after 4 monthis of unemployment) those out of work for longer periods can be distingulshed from those with disabilities of a less permenent nature. First, the former (1.e. those who were Interviewed three times) seemed to be in greater need of

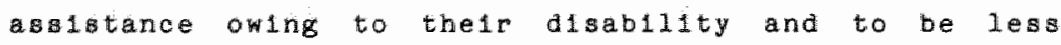
optimitic about the1r chances of recowery and of resuming work than the latter, 1.e. those who were able to return to work.

In addition, the results of the study would appear to 1ndicate that those unflt ror longer perlods are more soclally 1solated: they have close contacts with thelr relatives, but wlew the world at large as unfriendiy and host1le, unlike those wlth a short-tern disab111ty.

Chapter 7 summarises the results of the study and analyses the signirlcance of the various aspects of beling unfit to work, in relation to the meaning attached by individuals to the ractor "work".

This chapter also deals with a number of aspects which were not studied but which appear to be relevant to the subllect. In conclusion, the implications of the results are discussed and a number of practical consequences conslaered. 


\section{LIDERTWR}

ALLEGR, J.F. Humansering van de arbeld en ziekteverzuim. Lelider. Uniw. Pers, 1979.

AMTHONY, P.D. The 1deology of work. London, 1977.

ARENDT, H. De mens, bestaan en bestemming. Utrecht, 1968.

BAKKE, E.W. The cycle of adjustment to unemployment. In: Bel1, $N . W .$, E.F. Kogel (eds.). A modern introm duction to the family. Glencoe (II1.), Free Press, 1960.

BALLWEG, J.A. Resolution of conjugel role adjustment after retirement. J.Marr. Fam. $29(1967) 277-81$.

BECKER, J.W. Welnig kans op werk is geen inwallditelt. NRC/Handelsblad 25-10-1979.

BECKER, J.W. Werktijdwerkorting ondánks nieum arbeidsethos moeilidk. NRC/Handelsblad 27-3-1980.

BEERING, R. Arbeid, vije tijd, creativitelt. Den Haag, 1964.

BERENSCHOR, BOSBOOM \& HEGENER. EIndrapport betreffende het vervolgonderzoek uftvoering van de soclale verzekering op lange termign. Den Hag, 1979. (SER publicat1e nr. 15, $16-8-1979)$.

BERG, J.H. VAN DEN. De psychologie van het zlekbed. WlJkerk, 1957.

BESTEK 181. Hoofdlignen van het flnanolede en soclaal-economisch beleld van de middeliange termiJn. "Tweede Kamer der Staten Generaal, Zitting $1977 / 78 \mathrm{nr} .15081$.

BOSCH, F.A.J. VAN DER \& C. PETERSEN. De omvang van de verborgen werkloosheid in de WAO. Econ. Stat. Berlchten 65 (1980) $52-8$.

BoURs, J., e.a. WAO'ers, verhalen om te onthouden. N1jmegen, Link, 1980.

BREMER, J.J.C.B. De ziekenhuspatient. Nujmegen, 1972 .

BROER, J.F. WAN DEN, e.a. De werkloosheld en de grote onmacht die vreet an mensen. NRC/Handelsblad $14-2-1975$.

BRON, J.A.H. \& H.G. HAMAKER, Minder werken enig toekomit al ternatief. NRC/Handelsblad 9-11-1979.

CHODOFF, $\mathbb{P}$. Understanding and management of the chronicaliy 11 patient. Amer.Practit. 13 (1962) 135-44. 
CoHM, R.M. The effect of unemployment status change on selfeatiafation. Soclal Fsychol. 41 (1978) 81-93.

COLMAN, A.M. Soclal rejection, role conflict and adjustment; pschological conequences of orthopaedic disability. Percept. Motor Sk11116: 33. (1971) 907-10.

CRATIY, B.J. Soclal dimensions of physical activity. Englewood Cliffs (N.Y.), Prent1ce-Ha11, 1967.

DELOZN, M.H. VAN. Orientatie op werk en vrije t1jo. Grontingen, F.U., Soc101. Inst., 1970.

DIRKEN, J.M. Arbeid en stress: het vaststelien van aanpassingsproblemen in werksituatles. Groningen, WoltersNoordhoff, 1969.

DOEF, J. VAN DER \& P. VAN DER REIJDEN. Leemten In de sociale zekerhe1d. Soclal1sme \&emocratie 35 (1978) nr. 7-8, $346-58$.

DOORN, J.A.A. VAN \& C.J. LAMMERS. Moderne Soclolog1e, systematiek en analyse. Utriecht. Spectrum, 1964.

DROPPERT, M.H. De verborgen werklooshe1d. Econ.Stat.Berich$\operatorname{ten} 62(1977) 204-6$.

DURKMEIM, E. The diviaion of labor ln soclety. New York, Free Press, 1965 (1893).

EISENBERG, P. P.F. LAZARSFED. The psychologieal effects of unemployment. Psychol.Bull. 35 (1938) 358-90.

EMANUEL, H. Achtergronden van het arbeldangeschiktheldsversohijnsel in Nederland.

In: J.J. Klant e.a. Samenleving en onderzoek. Le1den, 1979, p* 94-133.

EMANUEL, H. e.a. Cross national disability study; the Netherlands; 2nd araft. Lelden, R.U./Center Res.Publ. Econom. 1980 .

EMMERIJ, L.J. \& J.A.E. CLOBUS. Volledige werkgelegenhe1d door creatief verlof. Deventer. 1979.

EMMERIJ, L.J. Werken voor een psychlach inkomen. NRC/Handelsbiad 13-9-1980.

F.N.V. (FEDERATIE NEDERLANDSE VAKVERENIGINGEN). Nota weerwerk. 1979.

FREIDSON, E. Profession of medicine. New Yark, bodd, 1975.

GADOUREK, I. Riskante gewoonten en zorg voor eigen welidjr. aroningen, Wolter, 1963. 
GALAN, C. DE. Ontwikkelingen in het versehilnsel arbeldsongeschikthe1d. Soc. Marabl. Arbeld 35 (1980) 888-93.

GERHARDT, U. Rollenanalyse als kritische Sociolagie. Beriljn, Luchterhand, 1972.

GOEDE, M.P.M. DE. Werken en niet werken. (2 dan) Utreoht, R.U.T. 1980 .

GOEDE, M.P.M. G.H. MASSEN. Meningen over werlozen en arbeidsangeschikten. Mens \& Mi. 55 (1980) 245-79.

GOFFMAN, E. Stigma. Englewood Cllffs, (N.Y.), Prentlce-Ha11, 1963.

GoLDSTEIN, H. Longltudinal studies and the measurement of change. Statistic1an 18 (1968) 93-117.

GORE, s. The effect of social support in moderating health consequences of unemployment. J.Soc.Behav. 19 (1978) $157-65$.

GROND, J.Th. D. DE PATER. Arts en arbe1dsongeschyktheid. Med.Contact $35(1980) 1131-6$.

HABER, L.O.\& R.T. SMITH. DIsab1l1ty and deviance, normative adaptions of role behavior. Amer.Soclol. Rev. 35 (1971) $87-97$.

HAGENDOORN, A. e.a. Het ascetische arbeldsethos; een explaratie. Gedrag, T. Psychol. 9 (1981) 2-19.

HAGGARD, $E$. On the reliablilty of the anamestic interview. Abr. Soc. Psychol. 61 (1.960) 311-8.

HAMAKER, H.G. Over werkloosheld; bespreking van enige recente "11teratuur. Soc.G1as 20 (1973) 369-85.

HARRIS, A.I. e.a. Handicapped and Impaired in Great Britaln. Part 1. London, HMSO, 1971.

HARTOG, F. Dubbele moraal. NRC/Handelsblad 20-11-1979.

HENRY, W. E. The role of work in structurering the 1 ife cycle. Hum. Developm. 14 (1971) 125-31.

HILVERTN, H.Q. Arbeidsongeschikt of arbeld ongeschikt? In: GemeenschappeliJke Medische Dienst. Arbeldsongeschikt, enkele invalishoeken. Amsterdam, 1977 , p. 65-82.

HOEVEN, P.J.A. TER. Naar een herwaardering van arbeld. In: Braak, H.j. v.d. e.a. Werkverlegenheld; invalshoeken op werklooshela. Alphen, Samson, 1979, p. 15-28. 
HoFFMA, L. Arbeldsvermindering als $1 \mathrm{nst}$. Lment voor de werk-

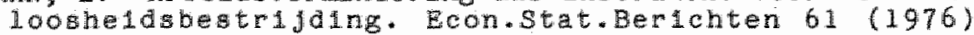
$437-42$.

HOdERZELI, H.H.W. Health care polieles and macro-diagnostic groups. T.Soc. Geneesk. 44.(1966)77-88.

HoUBE, P.P.J. Ervaringen er orluntaties van werklozen Mens en Onderm. 26 (1972) $282-94$.

HowaRD, A. R.A. SCoTt. A proposed framework for the analyis of stress in the human organlsm. Behav.So1. 10 (1965) $141-60$.

ILLICH, I. The right to useful unemployment. London, Boyars, 1978.

INSTITUUT VOOR PSYCHOLOGISCH MARKTONDERZOEK. Plaatsingsbeleld van werkgevers ten aanzien van gehandicaptien. is-Gravenhage, Vers1. Rapp.Soc.Zaken, $1970-4$.

IMSTITUUT VOOR TOEGEPASTE SOCIOLOGTE (ITS). Beroepenklapper. N1 megeri, 1973.

INTERIMrappart inzake de organisatie van de sociale zekerheid (departementale projectgroep, voorz. L. Lamers). Tweede Kamer der Staten-Gemeraal. Wite stukken nr. 15594, 28 me1 1979.

INTERMEDIAIR. Serte economie en pol1tiek in de jaren zeventig, P.A.G. Lansbergen (red.). Slotaflevering em literatuurl1 Jst $15-2-1980$.

KAHN, H. \& A.J. WIENER. Het Jear 2000, scenar10 voor de toekomst. Deventer, 1971.

KASL, S.V. e.a. The experience of losing a job; reported changes in health, symptoms and 1llness behav1or. Psychosom.Med. 37 (1975) 106-22.

KASSEBAUM, G.G. B.0. BAUMANN. Dimensions of the slck roie In chronic 111ness. J.HIth. Hum. Behav. 6 (1965) 16-27.

KLAAUH, M.M. VAN DEF. De samenstelling van de onderzoeksBroepen van het project "aampassing aan een arbeldiloos bestan". LeIden, NIPG/TNO (Intern rapport), 1975.

KMULST, W.P. Een week tija; rapport van een onderzoek naar de tijasbesteding van de Nederlandse bevolking in oktober 1975. "B-araventage, Staatsu1tgever11, 1977. (S.G.P.-Cander 10)

KNULST, W.P. T1gd zonder arbeld. Belleld : M1J., 5 (1979) $124-34$. 
ROSLEN, P.W. Beleving van arbelasongeschikthela en nelging tot werkervatting. Amsterdam, NIB-GMD res. 1975 (intern rapport).

RRAAYENSTEIN, M. W.C. VERBAAN. Het werklooshelasc1jfer, een slechte beleldsindicator. Soc.Mandbl.Arbeid 33 (1978) $420-6$.

KROON, P. Arbeld. Evangelle \& M11*30 (1977) 229-57.

KRUIDENIER, H. J. Het ontbrekende alternat1ef. Amsterdam, C.C.0.2., 1980 .

KWANT, R.C. De lotgevalien van het arbeldsbestel. Clvis Mund1 16 (1977) 177-84.

LAZARUS, R.S. Psychological stress and the coping procesi. New York, McGraw-H111, 1966.

LAZARSFELD, F. F*, M. JAHODA \& H. ZEISL. DLe AFbeltslosen von Marienthal. Wlen, 1933, (Psychol.Monogr. no. 5), Bonm, 1960.

LIPOWSKI, Z.J. Physical lilness, the individuel and the copling process. Psychlat. In Med. 1 (1970) 91-102.

LIPS, J.M. Relatie gehandicaptejnlet gehandicapte. T.Reval1dat1e 15 (1969) $237-45$.

LUDWIG, E.G. J. COLLETTE. D1sab1lity, dependency and conjugal roles. J.Marr. Fam. 31 (1969) 736-9.

MANSVELT, J. VAN, R.C. BRUNSTING, B.J.M. DELEMARRE \& H.A. VAN DER WAAL. Een onderzoek naar oorzakelilke factoren en bijzondere kenmerken bij het langerdurend arbeldsver $\mathrm{j}$ im I en II. Soc.MaandbI. Arbe1d 29 (1974) 379-89; 307-21.

MARTIN, J. M. MORGAN. Prolonged sickness, and the return to work. London, HMSO, 1975.

MASLOV, A.H. Motivation and personality. New York, Harper, 1954.

MERENS-RIEDSTRA. H.S. P.L. STROINK. Werklooshe1d, of a $\mathrm{r}^{*}-$ beld? als soclaal probleem. Mens \& ondern. 26 (1972) $279-83$.

MERENS-RIEDSTRA, H.S. Leven zonder werk; een onderzoek bid arbeldsorgeschikter; eerste deelverslag. Lelden. NIPG/TND, 1975 .

MERENS-RIEDSTRA, H.S. Leven zonder werk; een onderzok b1y arbeldsongeschikten; tweede interimwerslag. Leiden, NIPG/TNO, 1977 . 
WERENS-RIEDSTPA; H.S. Leven zonder werk; een onderzoek b1j arbeldsongeschikten; elnaversiag. Leiden, NIFG/TNO, 1978.

MERTON, R.K. social theory and soclal atructure. Wew York etc. Free Prese, 1967 .

HICHELS, J.J.H. Het Gezin wan de Ilchamell Jk chronisch zleke pat1ent. Kath. Artenb1. 47 (1968) 294-301.

MRC/HANDELSBLAD 29-1-1980. Albeda, wolledige baan voar leder b trake onmogel1jk.

NRC/HANDELSBLAD 19-6-1980. In 10 Jaar 800.000 arbe1dsongeBahiktien.

NRC/HANDE LSBLAD 14-8-1980. In 2000 m1joen mensen arbe1dsongesch1kt.

N.V.V.G. (NEDERLANDSE VERENIGING VOOR VERZEKERINGSGENEESKUNDE). Het onelgenl1yk gebrulk van artsen in de sociale verzekering. Arts soc.Verz. 14 (1976) 34-45.

NAGI, S.Z. Disab111ty and rehablittatior. Ohio, State Univ. Press, 1969.

NoTA volumebele1d. Z1tting Tweede Kamer der staten Generaal $1979 / 80 \mathrm{nr} .15650$.

OVESEN, E.E. Werklooshe1d. Rotterdam, Kooyker, 1977.

PARSONS, J. The social system, Glencoe (III.), Free Press, 1951 .

PAS, J.H.R. VAN DER. Koekoekseleren van de WAO. Soc.MaandbI. Arbe1d 34 (1979) 175-9.

PETRONI, F.A. The influence of age, sex and chronicity in percelved legitimacy of the slokmole. Soc1ol,Soc.Res. 33 (1969) 180-93.

PHILIPSEN, H. De voorwaamdel1Jkheld van algemene ultspraken toegellcht aan de samenhang tussen werkvoldoening en afwezighe1d wegens ziekte. Soc101.G10s 17 (1970) 320-33.

PHILIPSEN, H. Pleldool voor een vrijetijder; een minisoc10logie vari de relax.

In: Hoefnagels, H.J. e. R. Relax rleleks. Meppel, Boom, 1974.

PHILIPSEN, H. Enkele soolat-medische aspecten van arbelast1jdvarkorting en vervroegde penslonering. T.Soc. Qeneesk. $57(1979) 425-8$. 
SHowtz, F.C. Severe chronic 11lnes.

Iri: Garmett J.F. E.C. Levine. Psychologlcal practices with the fysically disabled. Columbia, Univ.Press, 1962, p. $410-45$.

SHOSTAK, A.B. W GOMBRG. Blue collar worla. Englewood Cliff's (N.Y.), Prentice Ha11, 1965.

SILLER, J. Psychological sltuation of the disabled with spinal cord injuries. Rehab.L1t. 30 (1969) 290-6.

SMIT, J. De minderhe1dsgroep met de thuswararde. Soclalisme \& Democratie 35 (1978) 461-76.

SMULDERS, P.G.W. De effecten van maatregeien om het ziekteverzulm te beInvioeden; een literatuurstude op basis ran 90 Nederlandse en buitenlandse emplistise onderzaek1ngen. Le1den, NIPG/TNO, 1980.

SOCLALISME en democratie. Naar een v1yfurige werkag; herverdeling van arbeld over seksen. Soclalisme Democmatie 35 (1978) no. 10 .

SOETERS, J. Afwezigheld wegens ziekte in het heristructurerungsgebied Zuld-L1mburg. Maastr1cht, RL, 1980.

STRCHTING WETENSCHAPPELIJK ONDERZOEK VAKCENTRALES. DE plaAtS van de arbeld, 1 en 2. Utrecht, 1975.

STOUFFER, S.A. e.a. Adjustment during army I1fe. The Amerlcan Soldier I. Princeton, Uniw.Press, 1949.

STROINK, F.L. Alternatieven voor arbeld. Le1den; NIPG/TNO, 1972, (1ntern rapport).

STROINK, P.L. \& M. WAN WIJCK. Jongeren en werk; nat een nieuwe werk-orientatie. Lelden, NIPG/TNO, 1973.

SWAAN, A. DE. Reformatle van de verzorg1ng. NRC/Handelsblad $6-4-1981,13-4-1981,27-4-1981$ en $4-5-1981$.

TELLEGEN, E. Alternatieven voor werkgelegenheld. Alphen a.d. R1jn, Samsom, 1980 .

THIEL, I.W. WAN \& H. WMGENAAR. Z1ek zijn; arbelasongesenikt worden. Amstercam, Un1w., 1975.

TONNIES, F. Geme1nschaft und Gesellschaft. Le1pz18, 1887 .

TOEDOIR, W.F., M.M. VAN DER KLAAUW C.M.J. VAN MANEN-BOEKESTEIN. "Projekt gezondheldszorg en lange zlekteduren; rapport 1, 2 din. Lelden, NIPQ/TNO, 1978.

UIJL, J.M. DEN \& H. KOMBRINK. Werkgelegenheld door solidaritelt. Tweede Kamer der Staten General. Witte stukken nr. 15800, oktober 1979, Begrot1ng 1979. 
WAL, W.D. H.L. WILLIAMS. Long1tudinal studes and the soclat sclences. London, 1970.

VISOMSYi, H. H. e.a. Coping behavior under extreme stress. Arch.Gen. Psych1at. 5 (1961) $423-48$.

WEBER, M. Die protestantwche Ethik und der Geist des Kap1talismus, I. Hamburg; Slebenstern, 1973 (1920).

WETENSCHAPPELIJKE RAAD VOOR HET REGERTMGSBELEID. Maken WIJ er werk van. Den Haag, 1977.

WETJEL, J.A., A.A. OOSTENERINK. Motivat1e en geschiktheld tot revalidatie. T.Soc.Geneesk. 48 (1970) 323-9.

WEZEL, J.A.M. VAN. Herintreding In het arbeldsproces, een onderzoek onder werklozen. T11burg, Glanotten, 1972. Proeftant 1 t.

WEZELI, J.A.M. VAN, A.L.J. VAN BOCHEM, A.M.C. VISSERS, E.a. De verdeling en de wardering van arbeld; een studie over ongelijkhe1d in het arbeldsbestel. T1iburg, IVA/Wetenschappel1yke Raad voor het Regeringsbeleld, 1976.

WIERSMA, D. Psychosoclaie stress en langdurige arbe1dsongeschiktheld. Groningen, R.U.G., 1979. Proefschrift.

WIERSMA, D. e.a. WAO en arbeldsmarkt, enkele bevindingen betreffende 54 gemeenten. Soc10l.G1ds 26 (1979) $265-82$.

WIPPLER, $R$. Soc1ale determinanten van het vrije-t1ja gedrag. Assen, Van Gorcum, 1968.

ZAAI, M. T. VAN. Arbeidsongeschikt; 1nvalide of onrendabel? Maanbl.Geest. Volksgezondh. 30 (1975) 539-53.

ZAAL, M*J. VAN. Van Invalidite1t naar arbeidsongeschiktheid; een onderzoeksvoorste1. B.W.0.-G.M.D. Amsterdam, 1975 b.

ZAAL, M.J. VAN. Eén loondervingswet is genoeg. Intermedialr 13 (1977) nr. 11, p. 1-9.

ZAHN, M.A. Incapacity, impotence and Invisibie Impalrments: thel fitects upon interpersonal relations. J.Hith. Soo. Behav. $14(1973) 115-23$.

ZUTHEM, H.J. VAN. Wat is de watrde van het werken in loondienst voon de werknemer. T.Soculanesk. 50 (1972) $465-72$.

ZWE DEN, A.F. VAN. Versneld afschrldven op mensen. Econ. Stat. Berlohten 61 (1976) 254 .

ZWEEDEN A.F. VAN. Arbeldsmarktbele1d wacht krachtproef. NRC/Handel sblad $3-4-1980$. 
ZWEEKHORST, W.A. Arbeldsongeschlkthedasverzeker1mgen; een glas voor medici en huipverleners. Utrecht, 1979.

2WEERLORST, W.A. Verborgen werkloosheid in de WAO. Intermediair 17 (1981) 5 Juni, p. 25-49. 
POPULATIE EN STEREROEF VAW HET BASISONDERZOEX

\section{Populatie}

1. Arbeldsongesch1kt kan iedereen worden, kostwinner of bulsyrowh, zelf tandige of werknemer, werknemer in (Bemi-)overheldbdienst of werknemer in het particuliere bedife $1 \mathrm{f}$.

Voor deze verschlilende categorledn werkers ziln er verschll lende regelingen voor loonderving bil arbeldsongeschikthe1d: de Zletewet en de Wet op de ArbeidsonBeschiktheldaverzekering voor werknemerg nlet in overheldsdienst, ultkeringen via het Algemeen Burgerlifk Pensioenfonds voor ambtenaren en slnds kort (1976, dus nog niet bif de anvang van dit onderzoek) de Algemene Arbelasongeschiktheldswet voor (vrljwel) ledereen (zie voor meer informatle over deze regelingen o.a. Zweek horet (1979) en Wlersma (1979).

om praktlsche redenen (betreffende de w1jze waarop namen en adressen van arbeldsongeschlkten konden worden verkregen) is de onderzoekpopulatie in eerste instantie beperkt tot ultkeringsgerechtigden krachtens de ziektewet of de WA, voor zover voorkomend in de administrat1e van het Gemeenschappelisk Admin1stratiekantoor en het Soclaal Fonds Bouwnijverheld.

De Ziektewet en de WAO worden ultgevoerd door de 26 bearlifsverenigingen ale Nederland telt; 14 daarkan hebben de bieraan verbonden werkzaamheden overgedragen aan net $a A x$.

Dit zijn de bedriffswereniging voor de:

02. zulveilindustrie

04. hout- en meubelindustrie

09. Bteen-, cement-, glas-en keramische industrie

10. metal en electronische 1ndustrie

11. metalnijverhe1d

13. chemische industrie

17. voedings- en genotmiddelen industrie 
19. haven en aanver qante bedrijuen enz.

20. koopvaaraly

21. vervoer

22. horeca bedrijven

24. overheidsdiensten

25. bank- en verzekeringswezen, groothandel en vrije beroepen

26. nlevwe algemene bedrijfsvereniging

De miet bIJ het GMK aangesloten bv-en omvatten:

01. agrarisch bedrijt

03. bouwnliverheid

05. textielindustrie

06 . kledingbedrij

07. 1eder- en Iederverwerkende industrie

08. grafische industrie

12. mifindustrie

14. tabakverwerkende 1ndustrie

15. bakkersbedin $1 \mathrm{fn}^{n}$

16. slagersbednjen vleeswarenbedridf enz.

18. detalihanded en ambachten

23. Bezondheld, geestel1jke en matschappeldjke belanEen

De beslissing om niet uit alle bedriffiverenlgingen (dus ook dle bulten het GAK) arbeldsongeschikten in het onderzoek op te nemen, berust vooral op het praktische gegeven dat de administraties lazake de verzekeringen tegen arbeidsongschiktheid soms zozeer van elkaar verschlilen, dat een unfrome selectie ter behowe war dt onderzoek onmogelijk zou zign. om deze veden 1 s ook overheldspersoneel buten beschouwing getaten.

Het GAK als "leverancler" van respondenten lag voor de hand, omdat dagmee op betrekkel1jk envoudige wijze een zeer groot deel van alle arbeldsongeschikten in het onderzoek kon worden opgenomen. Het beslutt om in tweede 1nstant1e, ook arbe1dsongeschtkten via het so- 
c1aal Ponds Bolwnijverheld in het onderzoek te betrekken, berustte behalve op het felt det de administratle darvan vrlywel hetzelfde 18 als die van het GAK, wooral op de overweging dat het secifleke karakter van het soort werk dat in de bouw wordt verricht (bultenwerk, wasende werkgever en werobjecten etc.) wellicht ook een specifleke nlet-werk problematiek met zich weebrengt.

(Met behulp van een t-toets 18 voor alle baslsvarlabeLen nagegaan of er verschilien tussen de GAK- en SFBteekproefonderdelen bestonden. Een enkele keer was dat wel het geval, maar dat leverde geen duldelilk systematisch verschil op.)

2. Het GAK en het $S F B$ kennen dezelfde procedure met betrekklrg tot de zogenaamie 10 -weeks gevalien en de adviezen elnde wachttid. De eerste worden uit de admlnistratle gelicht on te worden bekeken op eventueel noodzake11jke natregelen tijdens de well1cht nog lanBer durende zlektewetperiode. Het advies einde wachtt1jd houdt in dat de arbeldsongeschikte enige tijd voordat z1jn zlektewetyaar ten elnde loopt, wordt gemeld aan de Gemeenschappelijke Medische Dienst (die alle bedr1Jfsverenlgingen adviseert ten anzien van de witvoering var de WAO) voor een advies inzake onder andere het percentage arbe1dsongeschikthe1d. H1ertoe worden de desbetreffende dosslers meestal \pm 9 maanden na de eerste werk-loze dag uit de administraties van het $O A K$ en SFB gedicht.

Het ansluiten blj deze adminlstratieve handelingen voor de selectle van de onderzoekpopulatle vergde van het GAK en het SFB zo min mogelifk tijd en moelte.

3. De overwegligen biy de beperking van de populatie zoals in par. 2. 4 omschreven waren, wat betreft de versch11lende aspecten de volgende: 
a. Geslacht. Zowel de werkervaring als de betekenis van het niet-werken kan warschljnl1jk voor vrouwen 26 anders worden geacht dan voor mannen dat, zou men ook vrouwen willen bestuderen, dit apart zou moeten gebeuren. Dit zou ongeveer een verdubbeling van het aratal respondenten hebben betekend. hetgeen an flnanciele redener onmogellfk was. Bovendien zou de selectie van vrouwen veel langer hebben moeten duren om een voldoende aratal te krijgen, hetgeen niet wensel1jk was met het oog op de geflxeerde intervallen tussen ae interviews.

b. Burgerlijke staat. Dat alleen gehuwden in het onderzoek zijn opgenomen komt voort ult de wens een beeld te krijgen van (de veranderingen in) bet gezinsleven en het hulshouden. Deze zijn voor gehuwden en nietgehuwden niet goed vergelifkbaar. Bovendien zou ook de selectie van ongehuwden te lang duren.

c. Leeftlda. De keuze der leeft1jdsgmenzen berust op het belang van de "abnormale" uittrede ult het arbeldsproces na enige t1ja deelname daaram. De onderste leeftijdsgrens garandeert enige werkervaring (en 1 s ook relevant in verband met de els van het gehuwd-z1 $(n)$; de bovenste dat de meeste betrokkenen nog nlet toe aljn aan de gedachtengang wan de gepenslomeerden dat het in de $11 j \mathrm{n}$ der verwachtingen ilgt om met werken te stoppen.

d. Aandoentng. Verschllende aandoenlngen werden butten het onderzoek gehouden:

- psychische a andoeningen (groep V) 1 ) inciusief overspanning etc. Hier spelen weer vergel1 Jkbaarheldsoverwegingen eer rol. Onzeker is of en in hoeverre zowel de werk- als de nlet-werkervaringen van mensen die om psychloche redenen het werk neer moten leggen verschilien van die van om somatische redenen niet-werkenden.

Everals bif opmame van vrouwen in het onderzoek het geval zou zijn geweest, zouden bil opname van 
paychlsche gevalien de nocdzakelijke aratalien te groot geworden zijn.

De vraag of de oorzak van het neerleggen wan het werk door psychlsche of somatische factoren is veroorzakt, is niet altija genakmelifk te beantwoorden. Na overleg met de distrlctsartsen en adviserend geneeskundigen van resp. het SFB en het GAK, die de selectle op dit punt en op punt $f$ utvoerden, leek de beste formulering voor dit criterium: indien psychische factoren echt als voornaamste reden voor arbeldsongeschiktheld werden beschouwd (en daardoor in de administratie ook als dianose stond vermeld): dan nlet in het onderzoek opnemen. Is de psychische gestelaheld echter woornamelijk blyverachilnsel blj en somatische diagnose, dan wel opnemen. In twiffelgevalien werd door de arts de beslissing naar elgen inzicht gernomen;

- aangeboren afwljkingen (groep XIV); hierbij bestaat een te grote kans dat de afwijkirgen de werkervaringen te zeer hebben beinvloed en/of regelmat $1 \mathrm{~g}$ hebben onderbroken;

- nieuwrormingen (groep IT), goedaardlge èn kwaaaaardige, in verband met de dikwijls anwezlge kans op overlijden en/of de angst daarvoor, die alle andere ervaringen overschaduwt;

- aandoeningen die zeer warschijnlijk over niet al te lange tijd tot de dood zouden le1den;

- andoeningen die een gesprek extra compliceren of ormogel1.jk zouden maken, zoals doofheld e.d.

e. National1telt. Wat betreft de mogel1jkhe1d van ean gesprek werden bultenlanders bulten beschouwing gelaten, tenzw het reads lang met hun gezin in Nederland verblifwende en Nederlands sprekende bultenlanders zouden zijn (alt bleek trouwens zeer zelden het gevel). De verbliyfsdur en de aanwezig-

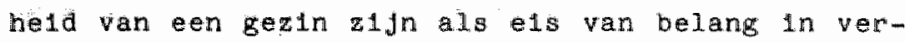


band met de overeenkomst met de Nederlandse arbeldsongeschikten.

f. Prognose werkhervatting. Het latste, maar nlet onbelangrijkste, criterium heeft te maken met de praktische gang van zaken bis het selecteren van potentiele respondenten met het $00 \mathrm{~g}$ op de kans op langdurlgheld van hun arbeldsongeschikthela. Tenelnde het vermodelijke percentage ultvallems na het eerste interview tot het laatste bił groep $A$ zoveel mogel1jk te beperken, werd in eerste 1nstantie am alle distrlctsartsen en de adviserend geneeskundigen van het SFB respectlevel1 $1 \mathrm{k}$ het GAK gevraggd om van alle aan de reeds besproken criterla beantwoordende mensen, diegenen nlet aan ons door te geven wan wie werkhervatting binnen een Jaar warsohijniljk was. D1t bleek na een week selecteren een zo moeliljk te hanteren criter1um, welks 1 nhoud bovendien in zeer sterke mate afhankel1jk bleek van de interpretaties der selecterende artsen, dat van gebrulk ervan werd afgezien. Daarna werden alle arbeldsongeschikten doorgegeven, wier werkhervatting niet al wrijwel zeker was. Aangezlen volled1ge zekerheld daaromtrent zelden a anwezlg 1 , werden toen vrljwel. alle arbelasongeschlkten die an de overige elsen voldeden, In de populatie opgenomen.

Dezelfde procedure werd gevolgd bly de selectie van groep $B$, met $a l s$ entge verseh1l dat de termijn warop In eerste instantle de voorspelling tot werkhervatting gedaan moest worden een half in plaats van én Jaar was. Groep C wera zonder enige langdurigheldsschatting geselecteerd, omat daamee geen tweede interview zou plaatswinden. De selectle van groep $D$ voor de tweede interviewserle werd ultgevoerd zoals bli groep $A$. 
4. De geng van waken b11 de gamenstelling van de populatie was als volgt:

a. de administraties en artsen war alie perifere resp. disulctikantoren van het OAX en het SFB selecteerdw op grond van de orlterla, huerboven genoem;

b. de geselecteerden kregen darna van deze instanties eer brief met het verzok om nedewerking, 1.c. toetemming nun gegewens aan het NIPG bekend te maken; Het bovenstaande geldt voor de 10-weekse gewallen en de adviesanvigen elnde wachtijd. Ten aanzlen van de Wa-era verllep het vrifwel identiek, behalive dan dat de selectie werd ultgevoerd door de administratie van het hoofakantoor van de GMD in Amsterdam.

\section{Steakproef}

1. De omvang ran de populat1e

De brulkbare geselecteerde onderzoekpopulatie (shet bestand waarul de steekproef kon worden getrokken) onvatue de volgende aantalien personen:

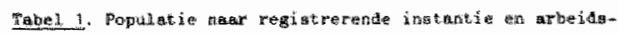

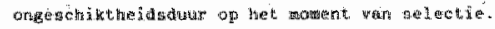

\begin{tabular}{|c|c|c|c|c|}
\hline Groep & 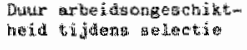 & GAK & $S F Q$ & Totasi. \\
\hline$A_{\text {光 }}$ & no weken & 627 & 203 & 830 \\
\hline "1:0 & 9 gramande $r$ & 155 & 473 & 328 \\
\hline$c_{16}$ & 15 migurghten & 525 & 1T & 496 \\
\hline$v_{4}$ & 10 wedtat & 605 & 223 & 620 \\
\hline Tut:and & & 1912 & 770 & 268 \\
\hline
\end{tabular}

Niet tot deze onderzoekpopulatie $z 1 \mathrm{jn}$ gerekend diegenen die vớr de interviews schriftelijk weigenden aan 
het onderzoek wee te werken or die bly eerste controle "rout" gealecteerd bleken: verkeerde diagnose, leeftija, ziektedur etc. De laatsten waren zeer gering in aratial. 2)

De we1gerimg vooraf bedroeg $10 x$ van groep $A_{4}$, 37 van $\mathrm{B}_{10}$ * 4 van $\mathrm{C}_{16}$ en $10 \%$ van groep $\mathrm{D}_{4}$ *

Woor zover bekend (van een deel der welgeraars werd géén gegevens van de selecterende Instanties verkregen) was de welgering gelifk verdeeld over de leeftijasgropen. Hoofdarbelders welgerden lets minder dan handarbelders, van wie vooral de sFB-groep in $\mathrm{C}_{16}$ sterk bij de welgeraars vertegenwoord1.8 was (13).

De weg van de onderzoekpopulatle naar de ultelndelijk gelnterviewde groepen was geplaveld met verschillende problemen, die gedeeltelldk wel en gedeeltelijk niet waren voomzien. 2 )

\section{Steekproefomwang}

De gewenste steekprofomang was gebaseerd op het minimal vereiste aantal respondenten b1j de laatste Interviews met ledere onderzoekgroep $\left(A_{16}, B_{16}, 0_{16}\right.$ en $D_{10}$ y: 180 à 200 , dat w1 zeggen \pm 20 respondenten per stratifloatie-cel ( 3 leeftijds- en 3 beroepsgroepen). op grond van GAK- en SFB-cijfers betreffende de aantallen arbeldsongeschikten met verschillende zlekteduren werd een schatting gemakt van het aantal respondenten dat big de eerste interviews met ledere sroep nodig was (aantal bij laatste interviens + geschatte u1twal). Naast de ultval tigdens het onderzoek door werkhervatting werd rekenins gehouden met andere ut valmogelifkheden. Door de whye van selectle èn var de amkondiglng wan het onderzoek b1 de respondenter werd deze extra u1tval laag verondersteja.

De aldus berekende minimale populatieomang zou in een maand geselecteerd moeten kunnen worden, volgens alle bekende gegevens. D1t bleek helas nilet het gevaln: 
wowel het antal ceselecteerde hoofdarbelders als sroep $B_{10}$ van het aAk bleven achter blj de gewenste steekproieromans.

Besloten werd alle geselecteerde hoofdarbeider en GAK 9-maandsgevallen in het onderzoek op te nemen. Hil valien steekproep en populatie dus samen.

\section{Gefaseerde steekproeftrekklng}

Teneinde de varlatie $1 n$ de duur van de arbeldsongeBchlithela (ten tijde van het interview) per onderzoekgroep zoveel mogelijk te beperken werd besloten het interviewen te laten beginnen nog voordat de selectle van de populatle was afgesloten. Behalve voor groep $\mathrm{G}_{16}$, die in éér keer in $\mathrm{z}^{\prime} \mathrm{n}$ geheel beschikbaar was, betekende dat dat werscheldene opeenvolgende keren een deel-steekproef moest worden getrokken op basis van de op dat moment aanwezlge populatle èn de verwachtlng omtrent de samenstelling van de uttelnde11jke populatie.

Tezamen met de noodzaak de t1jaens het interviewen aan de dag tredende grote ultwal (z1e 4) te compenseren resulteerde deze steekproeffasering in 5 trekkingen voor groep $A_{4} * B_{10}$ en $Q_{16}$ en 2 woor groep $D_{4}$.

4. U1tval tifdens de eerate interviews

Toen met de eerste interviews begomnen was in de eerste fase bleek de verondersteling, dat er weinig ultval. "tijdens" zou zijn, onjulst. Hieraan waren vooral de vele werkhervatters debet. Werkenden hoorden niet in de populatie thuis en deze mensen werden dus niet geinterviewd.

Andere ultwaloorzaken waren: welgering, te ziek, zlekenhulsoprame, $3 \times$ niet thuls, verhulsa e.d. 


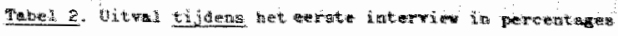

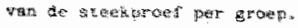

\begin{tabular}{|c|c|c|c|c|}
\hline \multirow{2}{*}{ Whtolis wegens } & \multicolumn{4}{|c|}{ 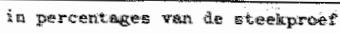 } \\
\hline & $A_{2}$ & 80 & $c_{n 6}$ & $\mathrm{~B}_{4}$ \\
\hline Werklkervat ina & 20 & 9 & 11 & $2^{t_{i}}$ \\
\hline webting & 3 & 2 & a & 县 \\
\hline owerat & 12 & 4: & Ha & $\pi$ \\
\hline Totearal thithal & 43 & 22 & 25 & $3 \%$ \\
\hline
\end{tabular}

B1j deze percentages is ultgegan wan de steekproef na alle trekkingen. Tussen de eerste en de latste trekklng 1 s steeds de ultval volgens de stand van zaken op dat moment gecompenseerd $1 \mathrm{n}$ de volgende trekk1ng(en). Dit kon echter niet bij de hoofdarbelders en de $B_{10}$ gevallen van het GAK, daar blj deze de gebele populatie in de eerste steekproef was opgenomen.

De totale èn de versohlliende soorten ultval waren niet alle evenredig verspreld over de ieeftijds- en beroepsgroepen.

Jongeren (25-39 jaar) bleken bljvoorbeeld relatief veel bij te dragen tot de uitval, vooral doordat zid vaker weer an het werk waren.

SFB-handarbelders welgerden relat1ef vaak, en GAKhoofdarbelders hadden het werk vaker hervat. Gezien de compensatie van de ultwal in de opeenvolgende steekproeftrekkinger betekent deze gedeeltelijk selectieve ultval niet, dat gevreesd moet worden voor een ernstige systematsche afwjking in de samenstuelling van de ultelndelijk geintervlewde groepen ter opzichte war de gewenste samenteling.

5. De u1te1ndel1Jke aantajlen geinterviewde arbeldsongeseh1kten

Deze stan vermeld in tabel 3 , welke niet alleen de resultaten van de steekproeftrekkingen $\left(A_{4}, B_{10}, C_{16}\right.$ 
en $\mathrm{D}_{4}$ ), bevat doch ook de aritallen personen, beschikbaar woor tweede en derde interviews. Aantalien warop de ondermoker zéen 1nvioed kon ultoefenen, doch die tot stand kwmen door tussentydse, nlet meer te compenseren, witual.

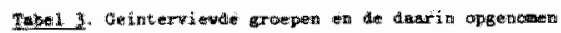

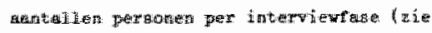

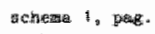

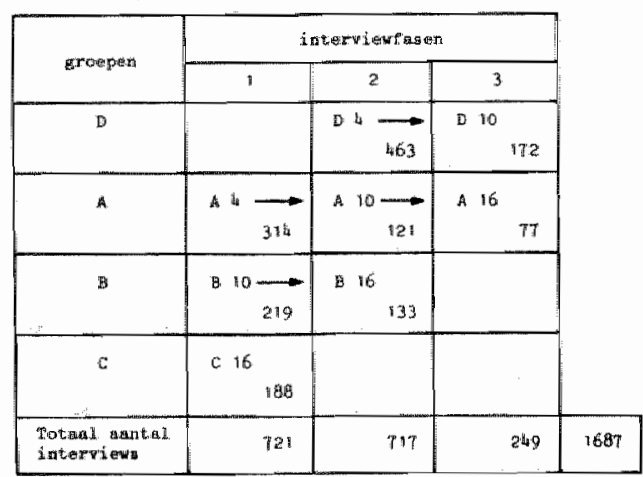

6. De ultwal na het eerste of tweede interview

Er zijn verschiliende redenen voor het felt, dat vele eenmal geintervlewde arbeldaongeschikten niet woor een-tweede en of derde interview beschikbaar waren. De belangrilkste hlervan is weer werkhervatting, de tweede $1 \mathrm{~s}$ weigering. averige oorzaken voor uitval waren: te zlek om een interviewer te word te stam, driemal niet thuls, verhulsd naar onbekend adres e.d.

van alle onderzoekgroepen 1 is in onderstande tabel vermeld welke percentages zisn uttgevalien, gesplitst In de ultval var vier nar tien meander arbeldsongeschiktheld ( $d . w . z$. wèl een interview bly vier maanden, gến bij tien maanden) en van tien naar zestien maanden. 


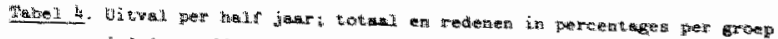

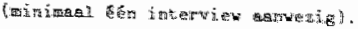

\begin{tabular}{|c|c|c|c|c|c|c|c|c|}
\hline \multirow{2}{*}{ groep } & \multicolumn{4}{|c|}{$I_{1}+16$ mamaden } & \multicolumn{4}{|c|}{ 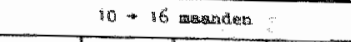 } \\
\hline & 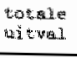 & $\begin{array}{l}\text { vert } \\
\text { hetwat }\end{array}$ & weinger & overie & $\begin{array}{l}\text { totiale } \\
\text { wistral }\end{array}$ & $\begin{array}{l}\text { mert } \\
\text { histrat }\end{array}$ & ver iger & oketi.t \\
\hline$A$ & 60 & $\operatorname{dit}$ & 11 & du & 30 & 18 & 10 & 88 \\
\hline B & $=$ & $\cdots$ & - & $-\cdots$ & 39 & $? x$ & $2 x_{4}$ & t: \\
\hline D & 63 & 46 & 9 & 6 & - & - & $m$ & $m$ \\
\hline
\end{tabular}

Van groep $A_{4}$ heeft $54 \%$ het werk hervat vobrdat men zestien maanden arbeldsongeschlkt zou zijn (47\% vốr er $7 \%$ nà 10 maanden); 25 bj1jft beschikbaar voor drie interviews.

Hoewel grote aantalien ultvallers bij het begin ven het onderzoek waren voorzien, 1 s vooral werkhervatuing vaker voorgekomen dan verwacht.

Dit werd verooraakt doordat de selecterende artsen (par. I.3.f) zeer voorzlchtig sellecteerden: de prognose "vpljwel zeker werkhervatten blmnen het onderzoekjaar" stelden zij zelden, zodat vrlywel alle $10-$ weeks en 9-maands "gevallen" in de steekproer terecht konden komen.

of men het aantal we1geringen om een tweede derde keer aan een interview mee te werken veel of welnig moet moemen is onduidelifk. Ir de literatuur over longltualnale onderzoeken 1 s dar niets over te vinden. Wèl wordt daarin altijd gewaarschuwd voor grote totale ultval. Aangezien werkhervatting een b1jzonder soort ultval 1s, die 1n andere onderzoeken niat vak zal wook komen, zou voozichtig kunnen worden gesteld, dat $10 \%$ welgering (groep $A$ en D) nuet veell is. De 24 van groep B lijkt echter wes veel.

De redenen voor welgering zign helabs in lang niet alle gevalien bekend. Ut de wiel beschikbare gegevens (mededelingen van de lnterviewers) komt de lndruk naar woren dat de witalchtlooshelo van de situatie wearin 
men werkeert en het vermoeden dat de interviews daarin geen verbetering kunnen brengen, een belangrljke rol hebben gespeeld. Voor een antal respondenten was het enotloneel te zwar or de eigen omstandigheden nog eens gronds door te spitten.

In de volgende tabellen $z i \mathrm{~g}$ de aantallen geinterviewde persorien en de tusientijase ultwal gespeciflceerd naar leeftijd en beroep; een specificatle derhalve yan de tabelien 3 en 4.

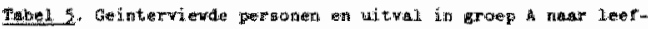

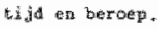

\begin{tabular}{|c|c|c|c|c|c|c|}
\hline & 4 axation & $\begin{array}{l}\text { geintert } \\
10 \text { tant }\end{array}$ & Wis ted & $\begin{array}{l}\text { percer } \\
4+10\end{array}$ & $\begin{array}{l}\text { tom witw } \\
10-16\end{array}$ & $4+16$ \\
\hline $25-39$ jotar & 103 & 35 & $1 \%$ & 66 & 51 & 84 \\
\hline Wowlig yirar & 119 & 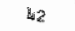 & 28 & 65 & 33 & 77 \\
\hline $50-55$ gar & 92 & 44 & 32 & 52 & 27 & 55 \\
\hline hoofdarbeid & 81 & 26 & 13 & 60 & 50 & 84 \\
\hline handarted & 233 & 25 & Gat & 59 & 33 & 73 \\
\hline rotand & 314 & 1.21 & 77 & 62 & 17 & 75 \\
\hline
\end{tabular}

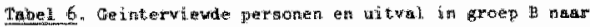
Iedertijen beroew.

\begin{tabular}{|c|c|c|c|}
\hline & 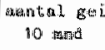 & $\begin{array}{c}\text { erviche whe } \\
116 \text { tand }\end{array}$ & $\begin{array}{l}\text { percentage daitwal } \\
\text { ven } 100^{-4} 16\end{array}$ \\
\hline $25-39$ ј јан & 57 & 3th & 4.0 \\
\hline 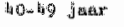 & 91 & 55 & 40 \\
\hline $50-55$ jowan & $y 1$ & blin & 36 \\
\hline 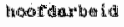 & 31 & $22^{n}$ & 28 \\
\hline nataderotbes & $1: S_{18}$ & รที & 4 \\
\hline Totand. & 219 & 193 & 39 \\
\hline
\end{tabular}




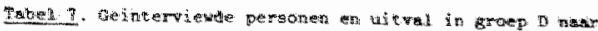

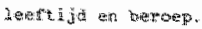

\begin{tabular}{|c|c|c|c|}
\hline & 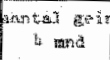 & 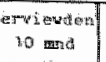 & 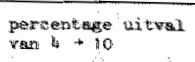 \\
\hline $25-39$ jEAr & 159 & 53 & 69 \\
\hline to-bo j:ar & 109 & 69 & 65 \\
\hline $50-55$ Joer & 105 & 52 & 51 \\
\hline bood dar teid & 82 & 30 & 63 \\
\hline branclar be id & 361 & $\hat{l}_{4}$ & 63 \\
\hline Totan & 463 & 172 & 63 \\
\hline
\end{tabular}

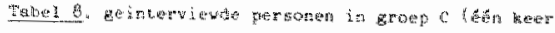

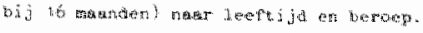

\begin{tabular}{|c|c|}
\hline $25-39$ บัar & $5 \%$ \\
\hline$t_{i}$ - & 66 \\
\hline $50-95$ jabr & $6 \%$ \\
\hline hoo ratat beid & $\pi 7$ \\
\hline 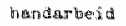 & bin \\
\hline $\cos \cos$ & 188 \\
\hline
\end{tabular}

Woor alle onderzoekgroepen is nagegaan af de ultvallers specifleke kenmerken vertoonden ten opzlchte van degenen die wèl twee- of driemal gelnterviewd zijn, niet allean wat betreft Iaeftijd en beroep, maar ten aanzien van alle bas 1 svariabelen. Voor de welgeraara bleek ds nlet ret geval, wel voor we werkhervaters en ae totale vitwal.

Werkmervatters werden relatief vak aangetroffen in de hogere beroepsgroepen en blj Jongeren. Bowendien was hun zlektetoestand gunstiger dan die van de blijvers: minder last, betere zlekteprognose. Daarnaast hadden zif werkhervatting waker voomspeld dan de blijvers. 3 ) 
De totale groep uitvallerg na éen of na twee intervlews verschilt slechts van de wèl twee- of drlemaal geinterviewden ten aanzlen van de ziektesituatie. Deze is bij vier of tien maanden arbelisongeschiktheid voor de ultvallers, het $11 \mathrm{gt}$ voor de hand, gunstiger. 


\section{Noten bil bijlage I}

1. Deze groepsiffers corresponderen met de indeling die door de bedrljeverenlgingen wordt gebrukt.

2. Een volledig overzlcht van de wijze van steekproeftrekken, de ultval vóor en tijdens het eerste interview, alsmede de ultwal daarna, gespeciflceerd nar verschiliende factoren 1s te vinden $1 \mathrm{n}$ een Intern NIPG-rapport van M.M. van der Klaauw (1975).

3. Gegevens over de verschillen tussen drlemal geinterviewden en werkhervatters met betrekking tot de variabelen van het definitieve onderzoek komen in hoofastuk 6 aan de orde. 


\section{VAN BELEVINOSTTEMS NAAR WARIABELEM}

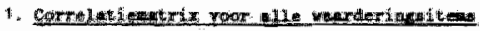

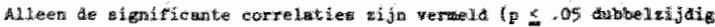
Bistoretriat).

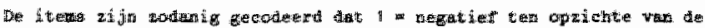

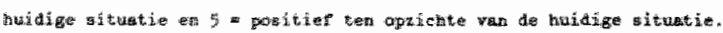

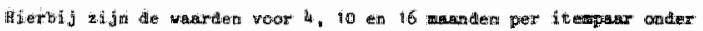
allikar operexom.

1. Lïever vandang

wan bet verk

$$
\text { iิ }
$$

2. nut deven war it 20 geven tis yoor hat hat

$$
1 \text { nee }: 9
$$

3. bertialt best

11. nee $26 \quad 36$

2930

4. prettige dingen $25 \quad 22 \quad 32$ oretragen 28 24 34 1 mes 21 li 30

5. ewain the veraluren is 13 ab 25 I) $=. j a \quad 19 \quad 20 \quad 27 \quad 30$

$\begin{array}{llll}15 & 14 & 21 & 27\end{array}$

6. leven wo a decht $13 \quad 17 \quad 26$ nog niet 22 ig $15 \quad 21$ $A=$ nee $\quad 17 \quad 21 \quad 18$

7. taekrmat scmber $08 \quad 10 \quad 10 \quad 19 \quad 42 \quad 26$ $1=5 a \quad 13 \quad 19 \quad 22 \quad 40 \quad 31$

Q. je trang je wir 11 $\quad \begin{array}{lllll}13 & 27 & 26 & 38 & 25\end{array}$ yharvom je leett 1.5 $\begin{array}{llll}10 & 15 \quad 25 & 25\end{array}$ 


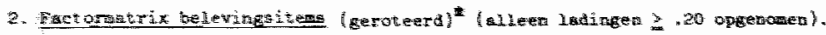

\begin{tabular}{|c|c|c|c|c|c|c|}
\hline \multirow[b]{2}{*}{ itederes } & \multicolumn{2}{|c|}{ Axuratop $1 .(4$ ond $)$} & \multicolumn{2}{|c|}{ 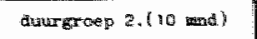 } & \multicolumn{2}{|c|}{ 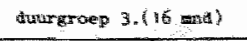 } \\
\hline & $\begin{array}{c}\text { factorladitu } \\
\text { ye }\end{array}$ & consu- & $\begin{array}{l}\text { factorlading } \\
\text { fia } 2 e\end{array}$ & malitert & $\begin{array}{c}\text { Paetoriading } \\
\text { te } \sum_{2}\end{array}$ & 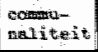 \\
\hline 7 & .145 & $\therefore 0$ & .39 & .17 & .44 & .20 \\
\hline $\mathrm{z}$ & .45 & 20 & .53 & 29 & .52 & .27 \\
\hline 3 & .52 & -29 & .60 & -39 & .57 & $=39$ \\
\hline 4 & $.5 t$ & .32 & .511 & .31 & .51 & .37 \\
\hline 5 & .26 & .36 & .33 & .36 & .52 & .33 \\
\hline 6 & .46 & 22 & .20 & .19 & .39 & .46 \\
\hline 7 & .60 & 37 & 62 & .41 & .57 & .36 \\
\hline 8 & .411 & .77 & .43 & .19 & .53 & 298 \\
\hline \multicolumn{7}{|l|}{ 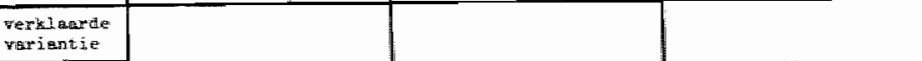 } \\
\hline werotenerd & .13 & & .13 & & .15 & \\
\hline origeroteda & .00 & & .07 & & .23 & \\
\hline
\end{tabular}

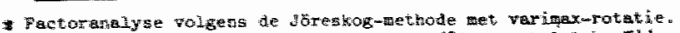

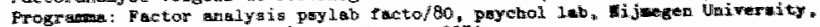

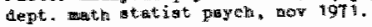


DE ACHTERGRONDEN VAN DE BELEVING PER SUBGROEP

In de tabelien 1 en 2 zin voor de twee belevingsdimensies zowel de of-orde correlatiecoeficlenten als de partiele correlatiecoefficienten vemeld met de 15 onafhankelljke varlabelen (woor zover signiflcant bij $p \leq .05$, tweezijalg getoetst), alamede de multipele regresslecouficienter. Dit alles apart per subgroep bimnen ledere duurgroep.

In de tekst 1 ten behoeve van de overzichtelijkheid in eerste instantle de nadruk gelegd op de verschillende facetten wan het leven zonder werk (zlekte, gezin enz.) als achtergronden van de wadrdering, en niet op de afzonderidjke onafhankel1jke varlabelen.

\section{De achtergronden van de satisfacte}

De sat1sfacte met het dagelljks beataan (llever vandag aan het werk dan morgen; doen waar geen t1jal voor was; bevalt best; vervelende dingen overheersen) hangt, zoals in tabel 1 te zlen $1 \mathrm{~s}$, met alle facetten van het leven zonder werk samen, zij het dat nlet leder facet op leder moment en bll ledere subgroep die samenhang laat zien.

De aandoenlng speelt bljwoorbeeld biy subgroep 4 en 5 geen rol en b1 subgroep 1,2 en 3 na 4 maanden niet meer.

Voor ledere subgroep zal worden aangegeven hoe groot de totale lrvloed van alle facetten tequmen op de satisfactie 1 . en wat de belangrijkste elementen daarbjj zijn wanneer de onderilnge samerhangen van de versch11lende variabelen In aanmerking worden genomen. 


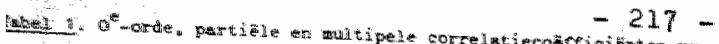

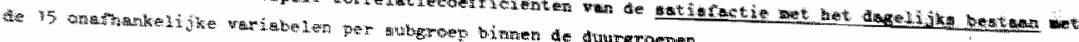

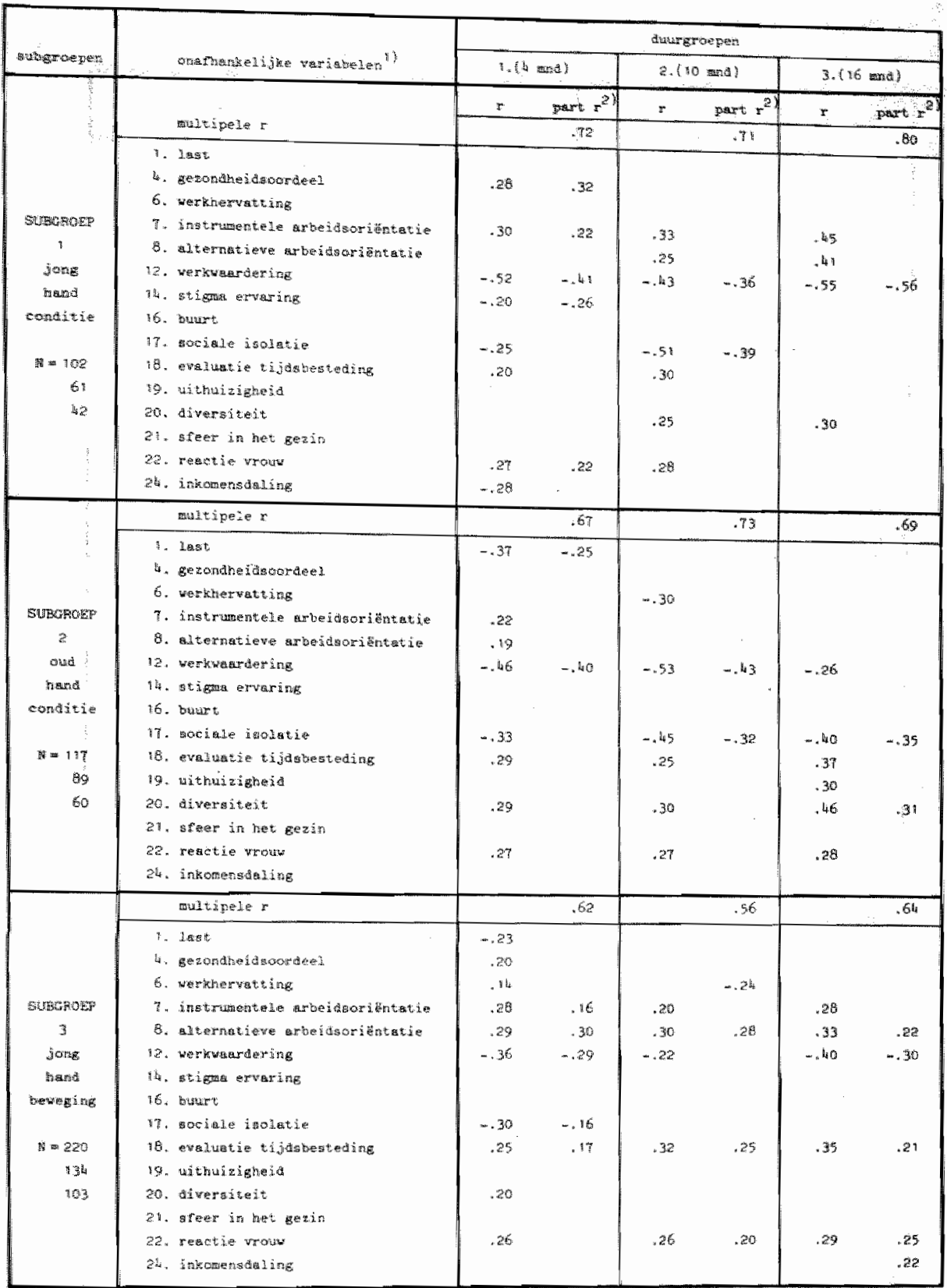

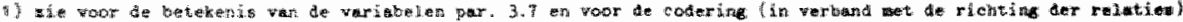
o.

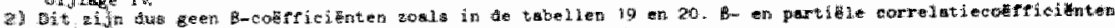

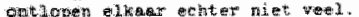


Hest 1. Herveg

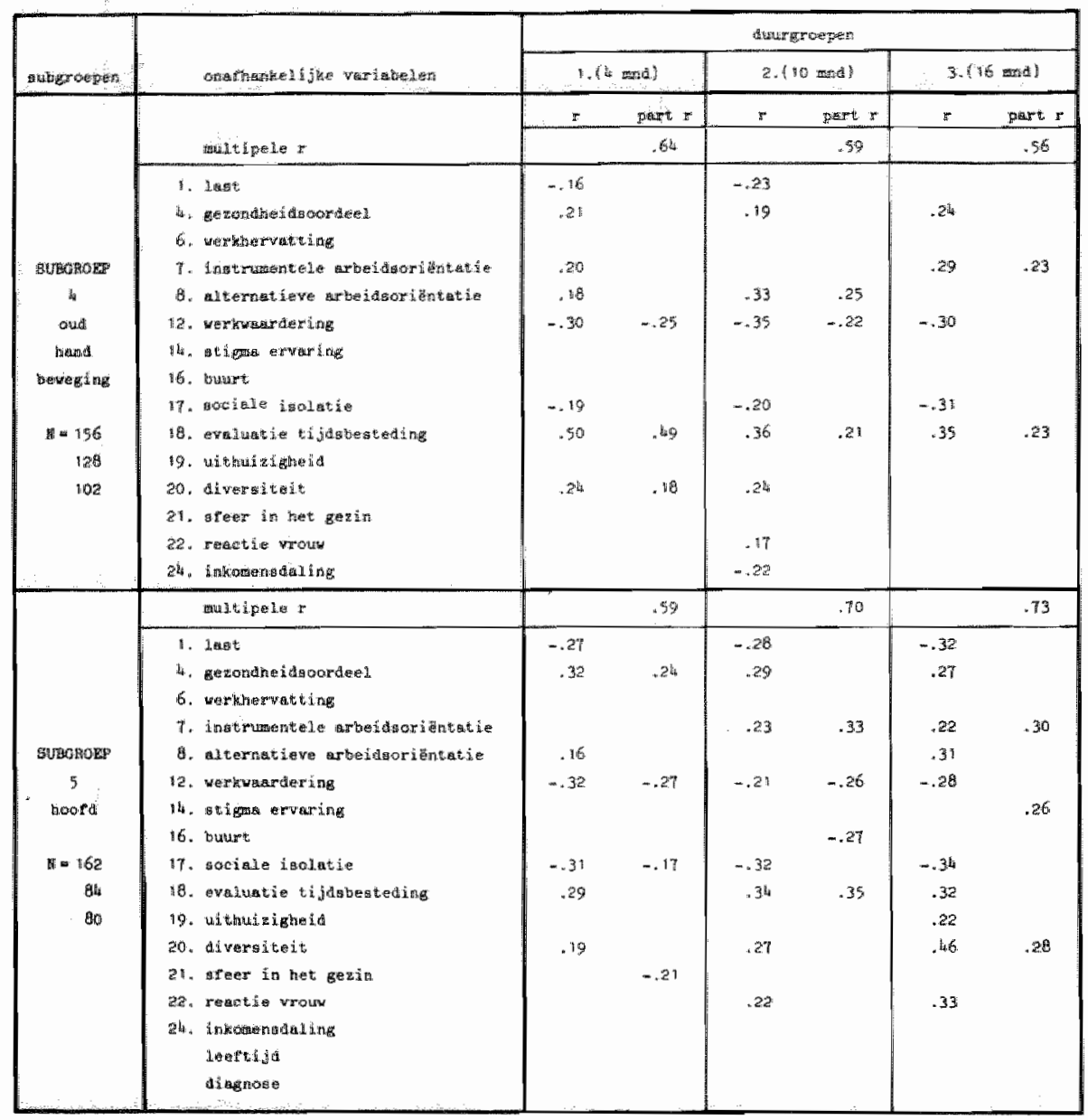


Subgroep 1. jonge handarbelders met een verwakte algemene lichamelljke conditie

De 15 onafhankel1jke varlabelen verklapen allen tezanen op de drie momenten 52,50 resp. 64 van de vamiantie van de satisfactie met het aggel1jks bestaan hetgeen meer is dan op grond van toewal verwacht kan worden (s1gn. blj p $\leq$ .05. tweezifalg). Dit zal overigens bij alle subgroepen het geval blijken.

De 1 dee bl1jken de belangrijkste invloed op de waardering te hebben. Hoe belangtifker men werken vindt, hoe tewredener men met het vroegere werk was en hoe meer men het mist (de werkwardering), des te negatiever oordeelt men over het huidige leven. Dit is na 16 maanden de enige achtergrond van de satisfactie.

op de tweede plaats komt de relatie met de omgeving: hoe meer men het gevoel heeft overal bulten te staan en how meer men ervaart dat de mensen fe anders bejegenen, een profiteur vinden of tot werken in staat achten, des te negatiever is de satisfactie.

Subgroep 2. oudere handarbelders met een verzwakte algemene lichamel1jke cond1tie

Vam de totale $1 n v l o e d$ op de satisfactie van deze subgraep $(45,53$ resp. 48\%) levert wederom de werkwardering de belangrifkste bijdrage.

De gevoelens van isolatie - als je niet werkt sta je overal bulten - komen op de tweede plaats.

Subgroep 3. Jongere handarbelders met beweging beperkygen Anders dan bif de arbeldsongeschikten met condtheproblemen $1 \mathrm{~s}$ de werkorlentatie, met name de alternatuewe, naast de werkwardering var belang. Hoe sterker men vindt "at je even boed andere dingen kunt doen dan werken" en "zow moeten kunnen klezen of je wilt werken of nlet" des hte tevredener 13 men met het nieuwe dagelijks bestaan. In tegenstelling tot de voorgaande subgroepen stat ook 
het belang van de tijdsbesteding, dat wi zeggen van de evaluatle dagrvan: hoe prettiger, nuttiger* wardevoller en boelender men de bezlgheden vindt en wo minder men zlch verveelt, hoe postulever de satufactie 1 .

De gezinsomstandigheden vormen de derde achtergrond van de Batiafactie van deze subgroep.

Pezamen verklaren de onafhenkelilke variabelen bly deze subgroep 38,31 mesp. 41\% van de varlantle van de satisfatcle op de drle momenten.

De aandoenling oefent geen invloed van enige betekenis ult op de sat1sfactie met het dagelijks bestaan, hoewel de ermee samenhangende wekhervatulngkans dat wa doet. Hierbly wekt de richting wan de invloed verwondering. Als men verwacht weer aan het werk te gaan, whd then de agen zonder werk onaangenamer dan als men het werk niet denkt te hervaten. Onverklarbaar 1 s behalve dit effect zelf waram het alleen b1. 10 manden arbelasongeschiktheld en alleen bij deze subgroep bestat.

Subgroep 4. oudere handarbelders met bewegingsveperkingen

Het inmidels vertrouwde beeld doet zich in eerste Imstantie ook voor bij deze subgroep. Alles bij elkar word een meer dan toevallig deel van de satisfactlevarlantie verklatrd (41, 35 resp. 31\%) en ook hier ziln de tdeeén over het werk(en) van groot belang. D1t keer evenals bij subgroep 3 zowel v1a de arbeldsorientatie als via de werkwardering. De eerste plats is nu echter niet exclusief voor dit facet weggelega: de tilasbesteding, met name de valuatle darvan, beIrvloed de wardering van het dagelijk bestan op leder moment ln vergelijkbare mate. De omgerling, de aandoening en het gezin spelen daarnaast geen rol van betekenls meer.

Subgroep 5. hoofdarbelders

Alle varlabelen teramen (inclusief leeftija en aandoening, die echter een zeer geringe, nlet signirloante invloed hebben) drasen 35,49 en 53 bly in de variantile van 
de satisfactie van de hoofdarbelders. 0ok blj hen voert de viste op het werk(en) de boventoon, warrolj, evenals bij sulogroep 4, de werkwardering vooral aan het begin en de (1nstrumentele) arbeidsorientatie vooral an het elnd hum. belang doen gelden. Als men werken een noodzakel1 jk kwad en nlet meer dan een middel om geld te verdlenen vindt, bevalt het niet-werken relatief goed.

In volgorde van belang komen daarna de omgeving, de tljdsbesteding, het gezin en de ernst van de aamoening. opmerkelijk is dat daarb1j drle varlabelen hun invioed op de satisfactie in onverwachte rlchting doen gelden.

- Weel stigmatisering (de mensen doen anders, vinden dat b1 profliteert en/of dat hij best zou kunnen werken) draagt vooral binnen een vertrouwde, gezelilige buurt bij tot een positieve satisfactle van de WAO-ers. BIJ nadere beschouwling blijkt vooral de ervaring dat men vindt at hij best zou kumnen werken hieraan debet te zijn. DIt zou kunnen w1jzer op de mogelijkheld dat WAO-hoofdarbe1ders dut oordeel van de omgeving in hun voordeel interpreteren: "ze vinden me niet helemal een kneusje", in plaats van "ze denken dat $1 \mathrm{k}$ de boel belazer, dat $1 \mathrm{k}$ nlet écht lets heb". Blifft echter wel de vraag, zoals ook blj de volgence afwljkende lnvloed, warom alleen bil deze subgroep en op dit moment.

- Een vertrouwde, gezelilige buurt le1dt na la maanden tot een negatieve satisfactie. Mogelijk is wellicht dat voor de noofdarbelders op dit moment de bemolenis/sociale controle binnen een dergelijke buurt meer irritatie opwekt dan de gezeligheld en vertrouwdheld kunnen compenseren.

- Ook de Invloed van de sfeer in het gezin wekt verwondering. Naarmate men de sfeer in het gezin prettiger en meer ontspannen vindt, des te negatiever oordeelt men over het dageligks leven. Dit ls echter een relatie die b1 alle subgroepen ( $\mathrm{z} 1 \mathrm{j}$ het niet signiflcant) aanwezig is. Een plausibele redenatie hiervoor is vooralanof moelijk te vinden. 
Vergel1yking var de subgroepen

In onderstaand schema is per subgroep de volgorde weer geveven, warin de verschiliende aspecten van het leven zonder werk doorklinken in de satisfacte met het dage11.jks bestarn, woor zover dat aan de partiele regressles 18 af te lezen. Dit schema 1 opgemeakt aan de hand van tabel 1 en $1 \mathrm{~s}$ derhalve een samenvatung van bovenvermelde regressieresultaten per subgroep.

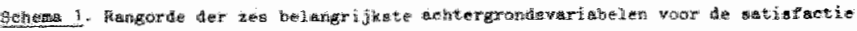
per thitigrow

\begin{tabular}{|c|c|c|c|c|}
\hline \multicolumn{5}{|c|}{ s:atogroforer } \\
\hline 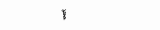 & $z$ & 3 & 缩 & 5 \\
\hline Keg & whyadider inge & 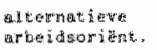 & 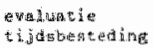 & $\begin{array}{l}\text { Enotrumentiele } \\
\text { arke idsoritent. }\end{array}$ \\
\hline Sioctitate & arediale & everilntête & 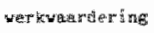 & werkwatardering \\
\hline 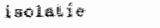 & foolatie & tidgbesteding & & \\
\hline 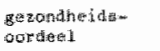 & 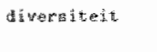 & wertwaskder ng & 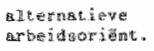 & $\begin{array}{l}\text { Qvaluatiz } \\
\text { tigdisterteding }\end{array}$ \\
\hline 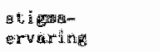 & 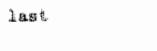 & reastie vroun & 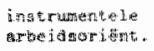 & divergituth \\
\hline 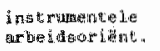 & & We thberwat cing & ditwergiteit & bustert \\
\hline $\begin{array}{l}\text { mater in het } \\
\text { grefrir }\end{array}$ & & inkondritade ing & & 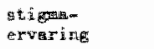 \\
\hline
\end{tabular}

Howel de verschllien tussen de subgroepen op het eerste gezlicht erg groat lifken $z_{1}$ jn er blj nadere beschouwing. ook overeenkomsten te ontdekken.

Allereerst is dat het geval wanneer in pleats van op de indulduele varlabelen de andacht gericht wordt op de facetten van het leven wonder werk. De v1sid op het werk (-en) stat dan b1y alle subgroepen bowenaan. Daarop volgt de colale 1 solatie voom de subgropen 1 en $2^{2}$ (handarbelders met verimate conditle) en de tijasbesteding voor de overige subgropen.

Fen zulvere wergelijking van de gubroepen levert bovenstande werkwize echter niet op; in schema $z$ zin 1 miners de effecten van de onathankelijke vartabeler voon 
de arle interviewmomenten tezamen genomen en terwlil en subgroepvergel1jk1ng per moment zou moeten platsvinden. D1t nu is gebeurt met de LISREL-analyse (z1e bljiage IIIo woor een beschrijving van deze techniek). Daarult bl1 $1 k t$ dat de resultaten voor de subgroepen per moment in grote $11 j n e n$ hetzelfie $z 1 \mathrm{Jn}$, met ultzondering van subgroep 4 bly 4 maanden. Bij deze oudere handarbeiders met bewegingsaandoeningen is de evaluatie van de tijdsbesteding belangrijker dan blj de overige subgroepen; de last van de zlekte daamentegen minder belangrijk (zle voor een bespreking van deze afwijking en van de algemene lijn per duurgroep par. 4.5 en 4.6 ).

2. De achtergronden van de algemene. levenshouding

B.j een eerste inspectie van tabel 2 valt allereerst op dat de werkwaardering in het geheel geén inwloed ultoef"ent og de levenshouding ( $1 \mathrm{k}$ heb het zwar te verduren, het leven is zo slecht nog niet, ik zie de toekomst somber in en Je wraagt Je wel eens af warvoor Je leeft). Een grotere tegenstelling met de satisfactie $1 \mathrm{~s}$ nauwel1jks denkbaar. Wèl gelat ook hier, dat niet alle facetten en wariabelen op leder moment en bij ledere subgroep van gejijk belang zijn, doch dat $z 1 \mathrm{f}$ allen tezamen steeds een meer dan toevallig deel van de varlantie $1 \mathrm{n}$ de levenshouding verklaren (op één uitzonderıng na: subgroep 1, 16 maanden).

Subgroep 1. Jonge handarbelders met een verzwakte algemene conditie

De 15 onafhankeligke varlabelen verklaren teramen 42 resp. $48 \%$ en $48 \%$ van de varlantie van de levenshouding op de versohlliende momenten. Alleen b1y 16 maanden 1 s dat nilet significant (b1J $\mathbb{P} \leq .05$, tweezija1g getoetst $N=$ 4.). 


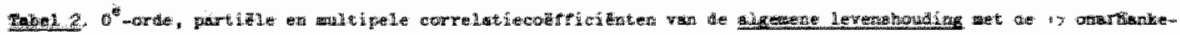

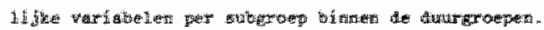

\begin{tabular}{|c|c|c|c|c|c|c|c|}
\hline \multirow[b]{2}{*}{ 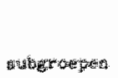 } & \multirow[b]{2}{*}{ 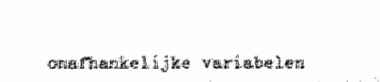 } & \multicolumn{6}{|c|}{ 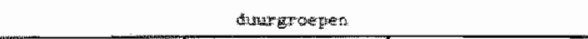 } \\
\hline & & \multicolumn{2}{|c|}{$1,\left(\frac{1}{2}: 01\right.$} & \multicolumn{2}{|c|}{$2 .\{50$ sind $\}$} & \multicolumn{2}{|c|}{ 3. (95. and } \\
\hline & & 5 & 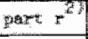 & $r$ & $p a T^{2}$ & 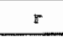 & 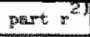 \\
\hline & mengigeder & & .65 & & .76 & & $\left.(.69)^{3}\right)$ \\
\hline 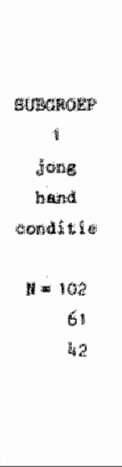 & 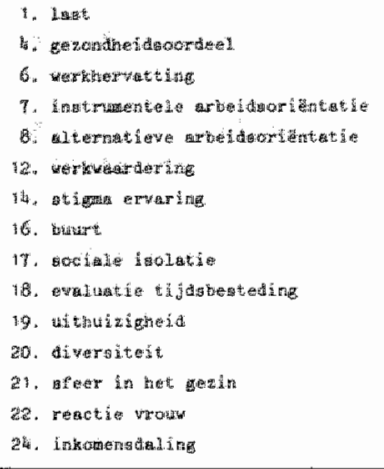 & .5 & 91 & $\begin{array}{r}-.36 \\
.52 \\
.37 \\
.27 \\
-.30\end{array}$ & $\begin{array}{r}.60 \\
-34\end{array}$ & .59 & .38 \\
\hline & multhtede $r$ & & $.7 !$ & & .66 & & .69 \\
\hline $\begin{array}{c}\text { SUEGROEP: } \\
2 \\
\text { oud } \\
\text { hand } \\
\text { conditie } \\
k \times 147\end{array}$ & 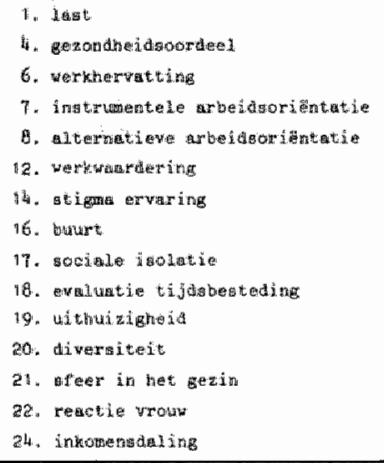 & $\begin{array}{r}-.37 \\
.33 \\
.90 \\
.29 \\
. .27 \\
\ldots .927 \\
.47 \\
.23 \\
.61 \\
.20\end{array}$ & $\begin{array}{r}.21 \\
.23 \\
-.32 \\
.29 \\
.30\end{array}$ & $\begin{array}{r}-.28 \\
-.25 \\
.36 \\
.38 \\
.23 \\
-.26\end{array}$ & $\begin{array}{r}-.26 \\
.31 \\
-.26\end{array}$ & $\begin{array}{r} \\
\\
-.28 \\
.27 \\
.28 \\
.26\end{array}$ & $\begin{array}{r}.50 \\
-.30\end{array}$ \\
\hline & maltipele & & .58 & & .61 & & -7! \\
\hline 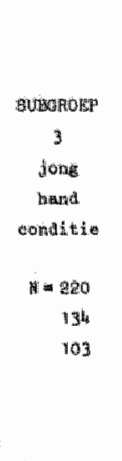 & 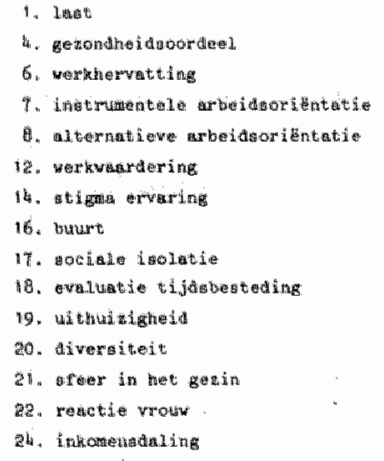 & $\begin{array}{r}.36 \\
.35 \\
.30 \\
.2 \pi \\
-.19\end{array}$ & $\begin{array}{r}-.26 \\
.17 \\
.26 \\
-.16\end{array}$ & $\begin{array}{r}-.21 \\
-.33 \\
.30 \\
.30 \\
.28 \\
.2 \text { h }\end{array}$ & $\begin{array}{r}.22 \\
.10 \\
.22\end{array}$ & $\begin{array}{r}-.57 \\
.48 \\
.42 \\
.26 \\
.36\end{array}$ & $\begin{array}{l}-.40 \\
.2^{4}\end{array}$ \\
\hline
\end{tabular}

1) Tie noot tabei 1 .

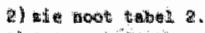


3lechts enkele varlabelen oefenen rechtstreeks invloed ult op de levenshouding. In de eerste platis is dat de tigdsbesteding (vanaf 10 matrden), gevolgd doof de werkhervatting prognose en de gevoelens van 1 solatie.

Ten anwlen wan de verwachting weer an het werk te gaan moet worden opgerwerk dat deze mu en zoals zal blijken ook b1 andere subgraepen en positlef effect op de levenshouarmg heeft, in tegensteling tot het (eenmalige) effect dat deze verwachting had op de satigfactie met het dage$11 \mathrm{jks}$ leven.

Subgroep 2. oudere handarbelders met een verwwakte algemene lichamejlike conditle

Van de 50\% resp. $44 \%$ resp. $48 \%$ die de onathankelijke varlabelen verklaren van de varlantie in jevenshouding, lewert dit keer de ernst van de zlekte de grootste bljdrage: naamate men zlchzelf meer zlek dan gezond voelt heeft men een somberder levensvisie.

De ongeving, de t1jdsbesteding en het gezin volgen echter met een rijwel gelijkwaardige invioed op de levenahouding. Een grote werkhervattingskans zorgt in het begin weer voor een positleve levenshouding.

Subgroep 3. Jonge handarbeiders met bewegingsbeperkingen

De menlng overal bulten te staan als je niet werkt is roor deze subgroep de belangrifkste herkerbare reden om het leven somber in te zien. Met de andere variabelen verklaart dit wederom een significant deel van de beleving varlant1e: 34,37 resp. 50\%. De tijabesteding is, evenal de 1solatiegevolens, op leder moment van belang: Anders dan blj de satisfactle wordt dit niet alleen door het oordeal over de t1Jdsbesteding veroorzakt, mar evengoed door de am en het a antal bezigheden (hoe meer hoe beter). De negatieve werkhervattingsprognose stemt wederom ( $1 \mathrm{n}$ het beg $1 \mathrm{n}$ ) tot somberbe1d. 
Subgroep 4. oudere nandarbelders met bewegingsbeperkingen opmerkel1 $\mathrm{jk}$ blj deze subgroep is dat de tljdsbesteding de levenshouding niet rechtstreeks beInvloed. Opmerkel1 $\mathrm{gk}$ 18 eveneens dat het accent van de achtergronden voor de levenshouding van 4 nagr 16 manden verschuift van de ernst van de ziekte inclusief de werkhervattingsprognose naar de omgeving.

De total verklaardie varlantle verandert daarmee niet: 35 ; 41 en $32 \%$.

Subgroep 5 . hoofdarbelders

Evenmin als de satisfactle met het dagelljks bestaan blijkt de kljk op het leven van hoofdarbelders af te hangen van leeftijd of globale aandoening. De andere varlabelen hebben echter wederom een zeer gewarleerde 1nvloed. Tezamen verklaren ze 44,59 en $55 \%$ van de varlantie in de levenshouding.

De omgeving en het gezin dragen de gehele onderzochte arbelasongeschlktheldsperiode bly tot de levenshouding met name via de gevoelens van lsolatie en de sfeer in het gezin.

Opvallend is dat de buurt, evenals bil de satisfactie ultsluitend bij de hoofdarbelders invioed ultoefent en wederom in niet voor de hand liggende richting: een niet vertrounde, ongezeli1ge buurt draagt bij tot een optimistische levensvisie (z1e pag. IIIa.4). 
Verge11 thing van de subgrogen

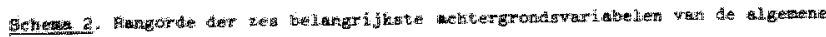

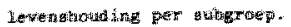

\begin{tabular}{|c|c|c|c|c|}
\hline \multicolumn{5}{|c|}{ gubtorspen } \\
\hline 1 & 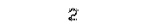 & 3 & 4 & 5 \\
\hline 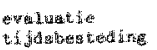 & 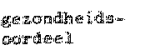 & $\begin{array}{l}\text { stowale } \\
\text { ísolatie }\end{array}$ & 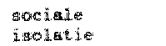 & 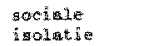 \\
\hline 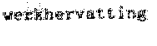 & 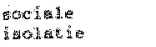 & 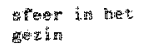 & 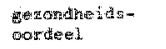 & 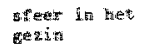 \\
\hline 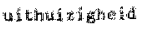 & divergitoit & Getersiteit & 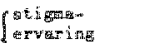 & 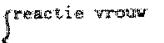 \\
\hline \multirow[t]{3}{*}{$\begin{array}{l}\text { Hociale } \\
\text { itolatio }\end{array}$} & $\begin{array}{l}\text { sfeter it net } \\
\text { gextin }\end{array}$ & 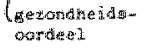 & 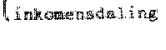 & 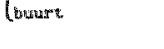 \\
\hline & $\begin{array}{l}\text { indtrutientele } \\
\text { arbeftooritent. }\end{array}$ & at thatzigreid & 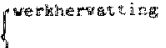 & 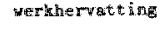 \\
\hline & $\begin{array}{l}\text { Evaluat le } \\
\text { tijats beaceding }\end{array}$ & Merkforvatting & lome & $\begin{array}{l}\text { eralwatse } \\
\text { tinfobesteding }\end{array}$ \\
\hline
\end{tabular}

Dok voor de algemene levenshouding blljken de achtergronden tussen de subgroepen minder werschillend dan op het eerste gezicht lifkt. De soclale lsolatie woert bif alien de boventoon, gevolgd door de evaluatle wan de t1jisbesteding. D1t mal wordt het algemene beeld voor de arle duurgroepen verstoort b1j de 10 maandsgraep.

B1 $\mathrm{J}$ subgroep 1 heeft de evaluatie wan de t1jasbesteding op dat moment meer invloed op de levenshouding dan bij de andere subgroepen en bif subgroep 4 heert de last van de aandoening meer en de sfeer in het gezin minder effect dan b1j de andere (zle verder par. 4.5 en 4.6 ). 


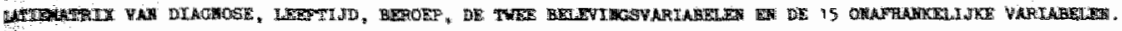

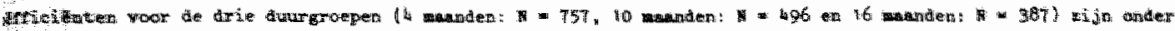

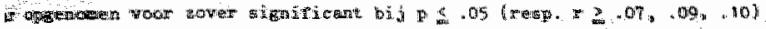

disensis:

it

iget thita

$1:$ jancs

$-12$

$-10$

arter

$-13$

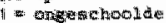

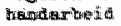

$-11$

atesigractie

$-10$

asgaijus

trestivisitat

-7 is

a.

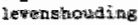

$\begin{array}{lll}-18 & 71 & 20 \\ -13 & & 25 \\ & 13 & 25\end{array}$

1ast

$\begin{array}{lllll}12 & 10 & -69 & -24 & -30 \\ 20 & & & -17 & -28 \\ 20 & & & -13 & -13\end{array}$

gersenthe i.dis-

expredeti

$\begin{array}{lllll}-15 & 42 & 22 & 35 & -142 \\ -12 & & 12 & 24 & -35 \\ -16 & & 19 & 26 & -34\end{array}$

$\begin{array}{llll}-12 & 12 & 26 & -35 \\ -16 & 19 & 26 & -34\end{array}$

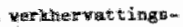
praigrapere

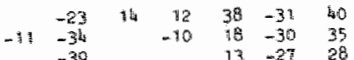

- inst rasidenteile

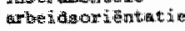

Wherratidere

arbeidsorientegtie

$\begin{array}{rrr}-20 & 22 \\ -14 & -1.4 & 17 \\ -19 & 24\end{array}$

10

$-09$

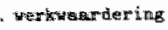

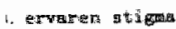

1

$$
\begin{aligned}
& 21 \\
& 24
\end{aligned}
$$$$
10 \quad \frac{24}{32}
$$

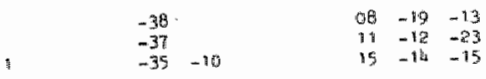

$$
\begin{array}{rrrrr}
-08 & & -09 & -15 & 0 B \\
-15 & -11 & & -21 & \\
-19 & & & &
\end{array}
$$

S. bucurth

$$
\begin{array}{rr} 
& -08 \\
-11 & -10
\end{array}
$$

\%. saciate jolatig

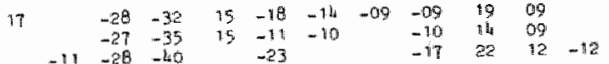

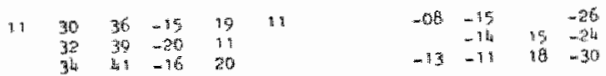

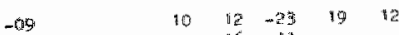

$$
\begin{aligned}
& 13-13 \quad 45 \quad 13-41 \quad \text { is } 13
\end{aligned}
$$

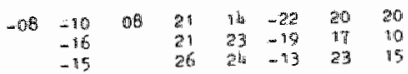

$$
\begin{aligned}
& 13 \quad 2 \quad 23 \\
& 23-13
\end{aligned}
$$

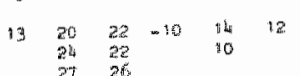

$$
\begin{aligned}
& \begin{array}{cccccc}
-96 & -17 & 16 & -09 & -13 \\
-16 & -12 & -48 & 10 & -79
\end{array} \\
& \begin{array}{ccc}
012 & -12 & 12 \\
-20 & 13
\end{array} \\
& \begin{array}{l}
12 \\
13 \\
15
\end{array} \\
& \begin{array}{lllll}
12 & -13 & 21 & 53 \\
11 & 12 & -16 & 31 & 45 \\
13 & 14 & -10 & 32 & 54
\end{array} \\
& 12-1104 \quad 26 \\
& \begin{array}{rrrr}
-17 & 08 & 36 & 10 \\
-13 & 19 & 35 & 10
\end{array} \\
& -09 \\
& -09-7 x
\end{aligned}
$$

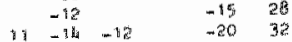

$$
\begin{aligned}
& \begin{array}{ll}
-16 & 2 \\
-16 & 2
\end{array} \\
& \begin{array}{l}
12 \quad 30 \\
17 \quad 30
\end{array}
\end{aligned}
$$

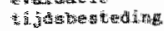

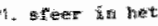

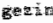

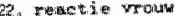

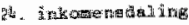




\section{LISREL ANALYSE}

\section{S1mutane regressie in vilf subgroepen}

De regresie-analyses, ale voor elk van de vifl subgroepen voor de arle tijastippen zijn uitgevoerd, leverden regresslecoèffliderten watrmee de nadruk kwam te 11 geen op de verachilen die er tusen deze groepen bestaar in de mechanismen dLe verantwordel1jk zijn voor het tot stand komen van de criterlumscores. Men kan zlch afvragen of deze mechanismen werkel1jk zo versch1ljend $z 1$ in als wordt gesuggereerd door deze aparte analyses, of dat er reden 1 om an te nemen dat de predictorvarlabelen global ongeveer dezelfde rol spelen b1y de vijf groepen. We nemen daarom voor het moment aan dat de regresslecoefflelënten woor elk van de predictorvariabelen hetzelfde zifn in elk van de viff groepen. Deze gemeenschappelljke warden kurmen worden geschat, gebrulkmakend van het programma LISREL van K.G. Joreskog en D. Sorbota. Tevens voorzlet dit in een $x^{2}$-toets voor de aanpassing, dat wil zeggen dat en toets wordt gegeven die aangeeft hoe goed of slecht het model met de waargenomen covariantiematrices te werenigen 1s. Het LISREL-model werd in 1973 door Joreskog geIntroduceerd. "LISREL" is een afkorting van "lynealre structurele relatiesth. In de algemeenste vorm bestaat zo'n model ult de specificatie van een causale structur tussen een verzameling latente varlabelen warvan somige worden beschouwd als af hankelifke vatabelen en andere als onafhankelijke variabelen. Deze latente warlabelen worden niet direct wargenomen maar er 1 s een antal. wargenomen variabelen die gerelateerd tifin an de latente varlabelen, in die zin dat de latente varlabelen oorzaak zlyn voor de wargenomen variabelen.

De situatie warme wij hier te maken hebben 1 s een zeer apecial geval van deze algemene vorm. De causale structur verbindt de onafhankel1jke varlabelen met het criterium. Zowel de onafhankelijke varlabelen als het critertum ziln echter niet latent mar wargenomen. In alt geval behandelen 
We deze varlabelen daarom alsof daarin de latente en de wargenomen versle samenvalien. Het daarmee verkregen model wordt toegepast voor elk van de subgroepen met de toegevoegde voorwarde, dat overeenkomstige regressiecoufficlenten dezelfde waarde hebben in elk van de subgroepen. 


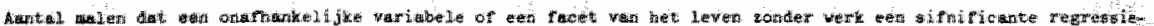

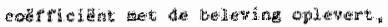

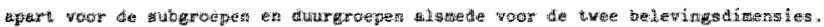

\begin{tabular}{|c|c|c|c|c|}
\hline \multirow{2}{*}{ 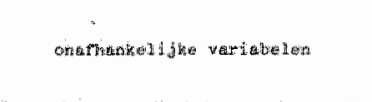 } & \multicolumn{4}{|c|}{ 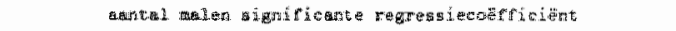 } \\
\hline & \multicolumn{2}{|c|}{ 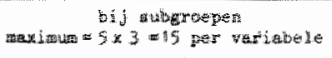 } & \multicolumn{2}{|c|}{ 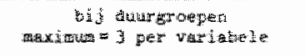 } \\
\hline & Eratistagtie & Leversetroudiras & getetistacie & Lewergatourit ing \\
\hline 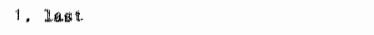 & 3 & 16 & 12 & $2 \geqslant$ \\
\hline 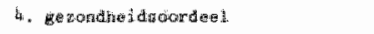 & 2) & $5 \int^{2}$ & 10 & 3 \\
\hline 6. Wretherwating & 1 & 5 & 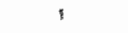 & 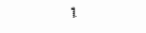 \\
\hline 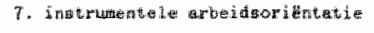 & 5) & a) & 3) & 13 \\
\hline 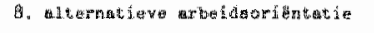 & 4320 & 3 & $3\}$ & -7 \\
\hline 12. vepkwardarting & 11) & -1 & 3) & -1 \\
\hline 14. stiona-sorvaring & 2 & 21 & 1 & 1 \\
\hline 16. bubre: & $1 \int^{3}$ & $8]^{3}$ & -17 & -1 \\
\hline 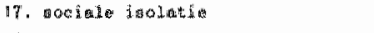 & $s$ & 10 & 3 & 3 \\
\hline 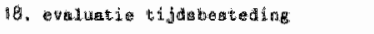 & ") & 5) & 3) & 3) \\
\hline 19. withulatghéd & $=10$ & $2 e_{0}$ & -35 & -3 \\
\hline 20. diverejutent & 3) & $3)$ & e) & -1 \\
\hline 21. areor in thet gezlin & 1 & 4 & 2) & a) \\
\hline 2.2. reatio wrow & $3\} 5$ & 190 & $3) 6$ & 6 \\
\hline 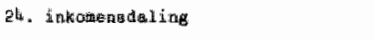 & 1) & 4) & $1)$ & $3]$ \\
\hline Iovertis & $n+t$ & nute & - & 2 \\
\hline bercep & nve & wat & 2 & - \\
\hline etandoenti ing & nvt & nowt. & घ. & - \\
\hline
\end{tabular}




\section{CURRICULUM VITAE}

In volgde het lager en middelbaar onderwijs in wassenaar, waar ik in 1964 het eindex men Gymasium- $B$ behaalde aan het Fijnlands Lyyceum.

Daarna vertoefde ik een Jaar aan het Plattsburgh state University College (New York, Werenfgde Staten) om in 1965 in Lelden met de studie westerse soclologie te beginnen. Het doctoraal examen werd in november 1971 cum laude behald met als hoofavak empirische en wijsgerige sociologie en als bijwakken sociale psychologie en methoden en teohnieken van onderzoek.

Vanaf september 1969 tot november 1971 was 1 werkzam als student-assistent van mevrouw M.J. Drop op het Nederlands Instituut voor Praeventieve Geneeskunde/TNo ten behoeve van het onderzoek "Kenmerken van gemeenten en verschilien in ziekte- en afwijkend gedrag" .

Wan november 1971 tot oktober 1978 was $1 k$ als wetenschappe$11 \mathrm{jk}$ medewerker verbonden an het NIPG/TNO, de eerste Jaren voor 8/10 werktijd en varaf oktober 1975 voor 5/10 werkt1ja. onderwerp van studie was hoofdzakel1jk het basisonderzoek "neven zonder werk"

Ma een kartistonolge Joopban als Ild van de Delftse gemeenteraad hield $1 \mathrm{k}$ m $\mathrm{j}$ vanaf 1980 bezig met het verwardigen wan het onderhavige proefschrift, mijn gezin en het huishouden. 


\section{DE CODERTNG VAN AFHANKELIJKE BN \\ ONAFHANKELIJKE VARIABELEN}

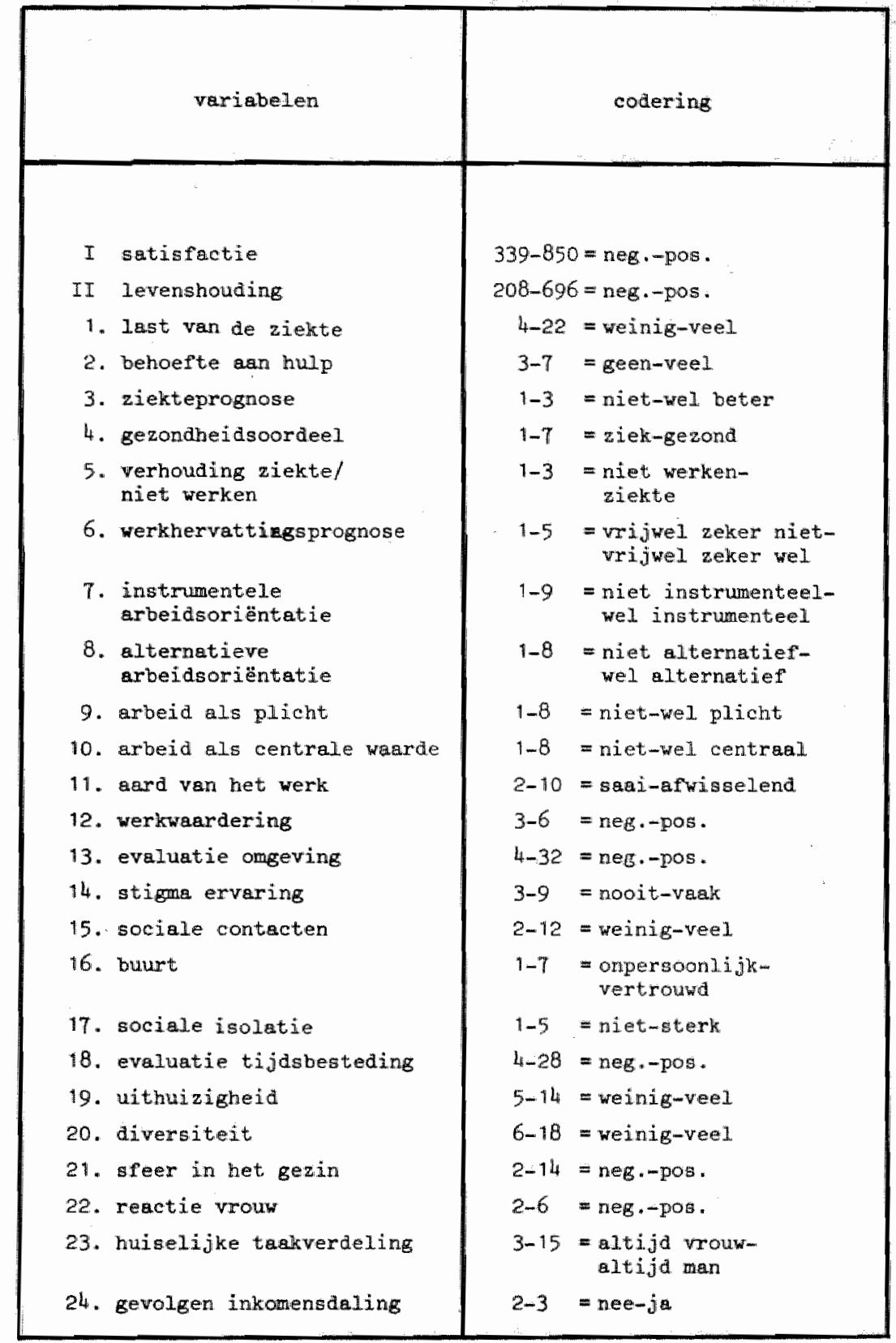

